UNIVERSIDADE DE SÃO PAULO

FACULDADE DE FILOSOFIA, LETRAS E CIÊNCIAS HUMANAS

DEPARTAMENTO DE LETRAS CLÁSSICAS E VERNÁCULAS

PROGRAMA DE PÓS-GRADUAÇÃO EM LITERATURA BRASILEIRA

MANUELLA MIKI SOUZA ARAUJO

O FRAGMENTO ROMÂNTICO EM O POEMA DO FRADE

Versão revisada

SÃO PAULO

2013 


\title{
O FRAGMENTO ROMÂNTICO EM O POEMA DO FRADE
}

\author{
Versão revisada
}

Dissertação de mestrado apresentada ao Programa de Pós-Graduação em Literatura Brasileira da Faculdade de Filosofia, Letras e Ciências Humanas da Universidade de São Paulo como requisito para a obtenção do título de Mestre em Literatura Brasileira.

Orientadora de acordo: Prof. ${ }^{a}$ Dr. ${ }^{\text {a }}$ Cilaine Alves Cunha

SÃO PAULO

2013 
Autorizo a reprodução e divulgação total ou parcial deste trabalho, por qualquer meio convencional ou eletrônico, para fins de estudo e pesquisa, desde que citada a fonte.

Catalogação na Publicação

Serviço de Biblioteca e Documentação

Faculdade de Filosofia, Letras e Ciências Humanas da Universidade de São Paulo

Araujo, Manuella Miki Souza

A663f

0 fragmento romântico em 0 poema do frade / Manuella Miki Souza Araujo; orientador Cilaine Alves Cunha. - São Paulo, 2013. $207 \mathrm{f}$.

Dissertação (Mestrado)- Faculdade de Filosofia, Letras e Ciếncias Humanas da Universidade de São Paulo. Departamento de Letras Clássicas e Vernáculas. Área de concentração: Literatura Brasileira.

1. Álvares de Azevedo. 2. fragmento. 3. epopeia. 4. sublime. 5. romantismo. I. Cunha, Cilaine Alves, orient. II. Título. 


\section{Folha de aprovação}

Nome: Manuella Miki Souza Araujo

Título: O fragmento romântico em $O$ poema do frade

Dissertação de mestrado apresentada ao Programa de Pós-Graduação em Literatura Brasileira da Faculdade de Filosofia, Letras e Ciências Humanas da Universidade de São Paulo como requisito para a obtenção do título de Mestre em Literatura Brasileira.

Área de concentração: Literatura Brasileira

Aprovada em:

Banca examinadora:

Prof. Dr.

Instituição:

Julgamento:

Assinatura:

Prof. Dr.

Instituição:

Julgamento:

Assinatura:

Prof. Dr.

Instituição:

Julgamento:

Assinatura: 
À memória de Nanci Akemi (1965-1992) e de Laura Tanaka (1948-2008). 


\section{AGRADECIMENTOS}

À professora Dr. ${ }^{a}$ Cilaine Alves Cunha pela orientação rigorosa e amiga com que vem conduzindo meus estudos de teoria romântica nos últimos sete anos, desde a época de iniciação científica.

Aos professores doutores Eliane Robert Moraes e Vagner Camilo pelas sugestões teóricas decisivas durante o exame de qualificação deste trabalho.

Agradeço também ao professor Dr. Caio Gagliardi pela indicação de leituras preciosas na ocasião do curso ministrado à pós-graduação em 2011.

Novamente, ao professor Dr. Vagner Camilo por aceitar, mais uma vez, acompanhar este trabalho na banca de defesa, na qual esteve presente também a professora Dr. ${ }^{a}$ Karin Volobuef, a quem sou grata por suas generosas contribuições teóricas.

Deixo registrada, ainda, a minha gratidão aos colegas Áriston Moraes Rodrigues, Constantino Luz de Medeiros, Erick Calistrato, Jefferson Donizetti Oliveira, José Guilherme Zago de Souza, Matheus Pazos de Oliveira e Wellington Migliari, que contribuíram de diferentes maneiras ao longo do processo de pesquisa, seja com sua disposição para ler, ouvir, discutir, indicar textos e eventos, ou ainda por compartilharem informações sobre prazos, normas e demais processos burocráticos. Além de todos eles, não posso deixar de mencionar Edmundo Juarez Filho, que incentivou minhas primeiras tentativas de estudar Álvares de Azevedo, durante a graduação.

Por fim, agradeço os estímulos, as prosas e a companhia de Arnaldo Pires Leite, Cristiane Asami Baba, Danilo Valderrama Banzatto, Hobert dos Santos, Jéssica Yuri Souza Araujo, Joyce Scarduelli, Lisi Pimentel, Maria Cláudia Conceição Moura, Marcelo Cardoso, Mariana Almeida, Patrícia Lima e Thalita Quachio em diferentes etapas desta caminhada.

Deixo registrado o reconhecimento à Fundação de Amparo à Pesquisa do Estado de São Paulo (FAPESP), pelo financiamento da pesquisa e pelas contribuições teóricas, inseridas nos pareceres dos relatórios de acompanhamento, valiosos para o andamento desta pesquisa. 
Há tanta poesia e, no entanto, nada mais raro que um poema! Eis o que faz a abundância de esboços, estudos, fragmentos, tendências, ruínas e materiais poéticos.

Friedrich Schlegel, Lyceum. 
ARAUJO, Manuella Miki Souza. O fragmento romântico em O poema do frade. 2013, 207 f. Dissertação (Mestrado em Literatura Brasileira). Faculdade de Filosofia, Letras e Ciências Humanas da Universidade de São Paulo.

\section{RESUMO}

A presente dissertação propõe examinar os traços de inacabamento na poética de Álvares de Azevedo e abordá-los segundo os fundamentos teóricos do gênero fragmento. O poema do frade, objeto deste estudo, é uma composição narrativa muitas vezes relegada a uma posição secundária na fortuna crítica do poeta Álvares de Azevedo; esta apreciação negativa deriva, justamente, de seu estilo irregular e digressivo, encarado como defeituoso. O poema do frade é fortemente marcado pela mediação de um narrador irônico, inclinado ao discurso devaneante, pouco linear e repleto de discussões metapoéticas. No poema, a multiplicidade de assuntos, aparentemente descontínuos, é unificada na tematização de um grande debate estético acerca da impossibilidade da epopeia na modernidade. Diante disto, O poema do frade dialoga com o polêmico projeto de composição de uma grandiosa narrativa épica no Brasil oitocentista, patrocinado pela política imperial local e alimentado, em especial, pelos poetas ligados ao grupo indianista. Ao problematizar a viabilidade da epopeia em seu tempo, Álvares de Azevedo realiza uma revisão da tradição poética neoclássica bem como de sua própria poética, colocando em prática o princípio romântico de aproximar os campos da crítica e da poesia, ou, em outras palavras, assimilar a reflexão crítica no interior da própria obra de arte.

Palavras-chave: Álvares de Azevedo; fragmento; epopeia; sublime; modernidade. 
ARAUJO, Manuella Miki Souza. The romantic fragment in O poema do frade. 2013, 207 f. Dissertation (Master). Faculdade de Filosofia, Letras e Ciências Humanas da Universidade de São Paulo, São Paulo.

\begin{abstract}
This dissertation aims at examining the unfinished traits in the poetry of Álvares de Azevedo, and approaching them using the theoretical fundaments of the genre "fragment". The object of this study, O poema do frade, is a narrative composing which is constantly relegated to a secondary position in the poet's critical fortune. This negative appreciation derives exactly from his digressive and irregular style, often seen as defective. O poema do frade is strongly characterized by the mediation of an ironic narrator, inclined to a rambling discourse, often nonlinear, and full of meta-poetic discussion. In the poem, the multiplicity of matters, apparently discontinuous, is unified in the thematization of a great aesthetic debate about the impossibility of an epic in the modernity. From this perspective, O poema do frade dialogues with the controversial project of composing an epic narrative in nineteenth-century Brazil, sponsored by the local imperial politics, and specially fed by the poets connected to the indianist movement. By questioning the epic feasibility in his time, Álvares de Azevedo performs a review of the neoclassical poetic tradition, as well as his own, applying the romantic principle of closing in the criticism and the poetry fields, or in other words, absorbing the critical reflection inside the work of art.
\end{abstract}

Keywords: Álvares de Azevedo; fragment, epic, sublime, modernity. 


\section{SUMÁRIO}

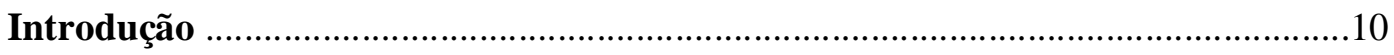

Apresentação de $O$ poema do frade ...........................................................10

O inacabamento na poética de Álvares de Azevedo .............................. 13

$\mathrm{O}$ inacabamento como forma e tema no romantismo ............................. 23

Roteiro do trabalho ....................................................................... 27

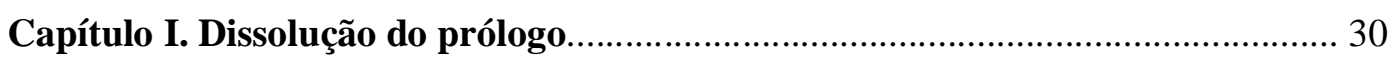

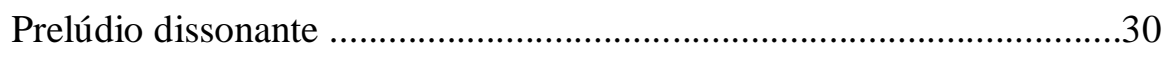

Prólogos indianistas: dois exemplos ................................................47

Alguns prólogos de Álvares de Azevedo .............................................53

Capítulo II. O livre perambular da imaginação ...................................................65

Movimentos do mar interior .............................................................65

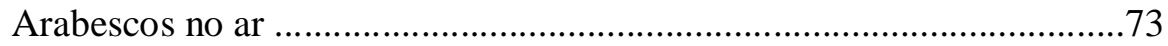

Desproporção e truncamento: o "atropelar de mil ideias" ......................83

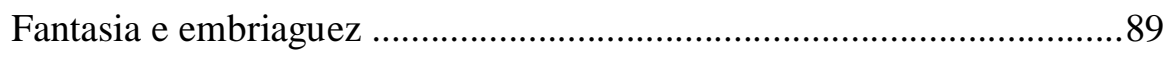

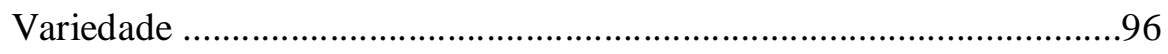

Linhagem digressiva ..............................................................102

Capítulo III. Falência da epopeia.................................................................. 108

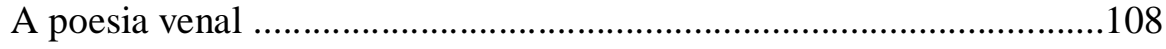

Tempo enoitado: "o cântico dos funerais da crença" .............................118

Complexo de Épico ............................................................................ 125

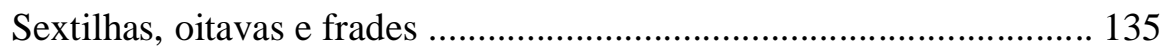

Condenação ao repouso ................................................................ 144

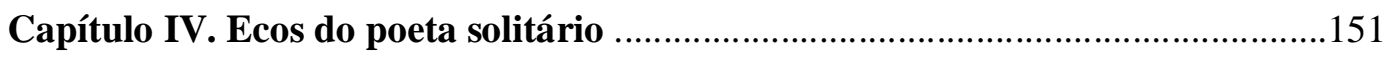

A chama se apaga ….................................................................151

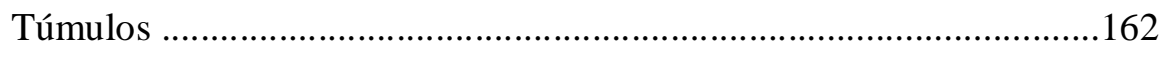

A solidão do narrador moderno .........................................................171

Subjetivação das formas: o auditório interno ......................................179

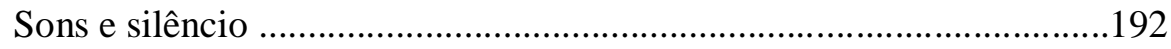

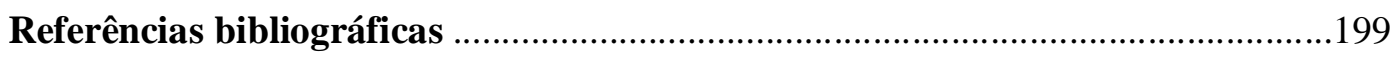




\section{INTRODUÇÃO}

\section{Apresentação de $O$ poema do frade}

Dentre as produções de Álvares de Azevedo, O poema do frade é uma obra quase desconhecida. Mesmo na fortuna crítica do poeta, ela é pouco estudada, aparecendo muitas vezes agrupada a outros dois títulos do mesmo autor - $O$ conde Lopo e O livro de Fra Gondicário - , por serem julgados rascunhos ou produções de menor apuro formal. O poema do frade apresenta uma estrutura bastante irregular e confusa, que desfavorece o estabelecimento de um assunto único e bem definido. $\mathrm{O}$ discurso de seu narrador é dividido em três eixos principais, que se estendem de maneira descontínua e desproporcional ao longo do poema. São eles: uma constante reflexão sobre o ato criativo; um enredo lacunar, que contraria sistematicamente os moldes da epopeia tradicional; e por fim, uma meditação sobre o tema da morte, mais predominante a partir da metade final do poema. Os três assuntos em questão não são distribuídos em uma sequência linear e hierarquizada; eles se alternam e por vezes se entrecruzam em um mesmo espaço textual, sempre pautado pelo fluxo digressivo e pela mescla estilística explorados pelo narrador. Todos esses assuntos podem ser unificados sob o tema da impossibilidade da epopeia e do heroísmo épico na modernidade. Esta perspectiva leva Álvares de Azevedo a tecer uma crítica ao projeto político-cultural almejado pela política do Segundo Império e especialmente abraçado pelos poetas indianistas, que se dedicaram à composição de uma epopeia nacional. Ao se posicionar no interior deste debate, Álvares de Azevedo também acaba por revisar a sua própria poética, questionando como os temas e formas propostos por ele podem representar satisfatoriamente ou não as contradições de seu tempo.

Como buscarei demonstrar nesta dissertação, a polêmica acerca da problemática viabilidade da epopeia na modernidade envolveu muitos autores do romantismo local e até mesmo alguns outros situados para além das fronteiras brasileiras. Azevedo propõe a incorporação de sua reflexão sobre a transposição da epopeia para o seu tempo no interior de seu próprio objeto artístico, entrando em consonância com a proposta romântica de revisão e ruptura dos rígidos limites que separam os gêneros clássicos, de modo a integrar diferentes campos do conhecimento. A mescla estilística em O poema 
do frade visa, sobretudo, a possibilidade de combinar em um mesmo espaço textual a poesia e a teoria sobre ela. A noção de crítica e crise dos modelos e valores consagrados, tomados pelos românticos numa perspectiva relativista, liga-se por sua vez à concepção de um tempo presente obscuro e decadente, destituído de fé e certezas, e portanto incompatível com a unidade e a confiança demonstrada pelo herói épico tradicional, celebrado como a expressão do auge de uma civilização triunfante.

O poema do frade foi publicado pela primeira vez em 1855, na segunda edição da obra completa de Álvares de Azevedo, preparada pela editora Garnier. O texto é dividido em cinco cantos de extensões desiguais, sendo os dois primeiros deles compostos em oitava rima, e os três últimos escritos em sextilhas. Em linhas gerais, a obra é estruturada da seguinte maneira: o narrador do poema anuncia, no Canto Primeiro, a sua intenção de narrar uma epopeia centrada em um herói denominado Jônatas. No entanto, essa proposta é sistematicamente frustrada; antes mesmo de anunciá-la, o narrador já sinalizara, no mesmo canto, a impossibilidade de realização desse objetivo. A caracterização das personagens, as opiniões do narrador e a escolha dos assuntos abordados no poema se afastam do repertório de uma epopeia: em $O$ poema do frade não há guerreiros nobres e virtuosos em batalha, mas um poeta libertino, uma prostituta, e um isolado frade-narrador, figuras solitárias e descrentes, em profundo conflito com a realidade "venal".

A contradição fundamental entre o que o narrador afirma e o que realiza em $O$ poema do frade é logo sugerida na problemática estruturação do Canto Primeiro, designado pelo narrador como o exórdio de sua "Odisseia". O preâmbulo em questão, por sua vez, se afasta deliberadamente dos preceitos de clareza e concisão na apresentação do assunto, conforme é procedimento recomendado na abertura das epopeias tradicionais. O que se vê no Canto Primeiro, de O poema do frade, é a exploração da prolixidade de um exórdio abrupto e instável, no qual se procura fugir de um assunto definido e fomentar a dúvida e a ambiguidade.

Ao longo dos cantos seguintes do poema, fica evidente a desproporção entre a reflexão do narrador, priorizada no texto, e a ação das personagens, que deveriam ser o foco principal de uma epopeia nos moldes antigos. Os devaneios e digressões não são, em O poema do frade, elementos marginais e secundários no discurso de seu narrador, mas antes parte das estratégias essenciais empregadas por ele na estruturação de sua obra. Esta se dirige a um auditório interno, pois a realidade fragmentada pela divisão do trabalho e pela crise espiritual, desencadeada após a Revolução Francesa, não favorece a 
unidade e a sintonia de espírito entre o poeta e a coletividade. Embora o narrador ironize no Canto Primeiro que não pretende falar de si, esta se revela a possibilidade precária no contexto de sua radical solidão.

Embora à primeira vista $O$ poema do frade pareça caótico, ao considerá-lo em seu conjunto pode-se perceber o estabelecimento de um evidente movimento descencional em sua última metade, que engloba parte do Canto Terceiro, seguido pelos quarto e quinto. Essa queda é articulada por meio da metáfora de um charuto que se apaga: sua fumaça transcendente é extinta com violência ao deparar-se com a frieza das águas oceânicas. Sem o refúgio da "nuvem azulada" o narrador é exposto às frustrações e contradições do mundo circundante. Essa imagem de desencanto sugerida na ideia de apagamento da chama (entendida como metáfora dos sonhos, da inspiração criadora) desencadeia um movimento negativo que leva à morte as personagens e faz ecoar solitária a voz do narrador. O entusiasmo épico não encontra lugar em uma realidade tomada pelo canto fúnebre.

As passagens ressaltadas no breve panorama exposto acima são alguns temas analisados mais detidamente ao longo desta dissertação. O esforço em parafrasear o poema se justifica pela necessidade de apresentar esta obra, pouco conhecida e dotada de uma estruturação problemática, responsável por complicar a sua legibilidade. A proposta deste trabalho é partir do estilo irregular e tendente ao inacabamento de $O$ poema do frade e discuti-lo segundo a concepção romântica - e idealista - de incompletude e rascunho. Formalmente, O poema do frade se mostra mais delimitado e completo que $O$ conde Lopo e $O$ livro de Fra Gondicário, nos quais parecem faltar alguns trechos; ainda assim $O$ poema do frade também pode ser, à sua maneira, considerado inconcluso, ao tematizar em seu interior uma reflexão infinita sobre uma meta inalcançável. A obra em questão discute a sua própria fragmentação, e realiza um balanço das respostas formuladas pela poética alvaresiana diante das soluções e caminhos estéticos propostos no romantismo de uma maneira mais ampla.

Após esta breve apresentação de $O$ poema do frade, segue um levantamento da escassa recepção da obra na fortuna crítica de Álvares de Azevedo. Nela, se percebe a constante abordagem deste poema a partir do critério do inacabamento formal, encarado na maioria das vezes com reservas. 


\section{O inacabamento na poética de Álvares de Azevedo}

O poema do frade não possui o mesmo destaque na fortuna crítica de Álvares de Azevedo, se comparado a Lira dos vinte anos e Noite na taverna, por exemplo. A obra em questão é geralmente citada com a finalidade de amparar análises dos títulos mais célebres do poeta e exemplificar procedimentos recorrentes em sua poética; ela também costuma ser associada a $O$ conde Lopo e O livro de Fra Gondicário, formando um conjunto de obras com um menor acabamento formal e fortes traços de inspiração byroniana. Por conta dessas características, O poema do frade, $O$ conde Lopo e $O$ livro de Fra Gondicário são consideradas produções esteticamente inferiores ou, ainda, menos "originais" em relação às demais composições de autoria de Álvares de Azevedo. A intensa presença de lugares comuns românticos, o discurso prolixo e as diferentes marcas de inacabamento fazem com que elas sejam consideradas defeituosas, exemplos da inexperiência de um autor adolescente, ou ainda resultado de publicações póstumas, que não receberam a devida revisão. Em resumo, O poema do frade, O livro de Fra Gondicário e $O$ conde Lopo seriam antes de tudo rascunhos, projetos, esboços:

Lembremos, a favor, que ela [a produção de Álvares de Azevedo] é toda de publicação póstuma, e as três que de fato o comprometem ( $O$ Poema do Frade, mas sobretudo $O$ Conde Lopo e $O$ livro de Fra Gondicário) são rascunhos juvenis que talvez não tencionasse divulgar, desesperadas tentativas de "byronizar", compreensíveis na pena de um rapaz de dezesseis ou dezessete anos. E isso nos faz voltar à influência [de Byron], tão referida e não devidamente estudada. ${ }^{1}$

ou ainda,

(...) se Macário, por exemplo, parece-nos um uso efetivo e bem-sucedido das possibilidades investigativas do gênero problemático romântico, o mesmo não se pode dizer de O livro de Fra Gondicário, que deve ser visto como um primeiro esboço, ou tentativa de algo que não chegou na verdade a se concretizar. O texto permanece mesmo assim fonte de grande interesse, pois permite vislumbrar com clareza certos procedimentos e tendências azevedianos. $^{2}$

A chamada poesia de matriz byroniana de Álvares de Azevedo foi encarada como defeituosa e inferior por grande parcela da crítica literária, que apontou na variação descontínua de registros ali observada a manifestação da oscilação própria de

\footnotetext{
${ }^{1}$ CANDIDO, Antonio. "Álvares de Azevedo, ou Ariel e Caliban”. In: Formação da literatura brasileira: momentos decisivos. 7. ed., Belo Horizonte: Itatiaia, 1993, p.167.

2 WERKEMA, Andréa. Macário, ou do drama romântico em Álvares de Azevedo. Belo Horizonte: Faculdade de Letras da UFMG. Tese de doutorado, 2007, p. 159.
} 
um autor jovem, sem maturidade no manejo da forma literária, ainda incapaz de conferir unidade às suas obras, bem como definir um estilo próprio. Para José Guilherme Merquior, Macário "é o menos ruim" dos "pastiches byronianos" de Álvares de Azevedo. O crítico cita um trecho da estrofe XXIII do Canto Primeiro de O poema do frade

Froixo o verso, pálida a rima Por estes meus delírios cambeteia, Porém odeio o pó que deixa a lima E o tedioso emendar que gela a veia!

como exemplo da "subestimação do trabalho consciente da linguagem poética; da parte da reflexão e do juízo no ato de escrever". ${ }^{3}$ Segundo Merquior, "a ausência do tedioso emendar se fará cruelmente sentir na produção ultrarromântica de Azevedo, muitas vezes bastante desleixada e desigual":

No caso de Álvares de Azevedo, esses defeitos têm maior saliência nos poemas narrativos de byronismo postiço $O$ poema do frade e $O$ conde Lopo, de versos prolixos e situações-chavão, muito inferiores à prosa também "maldita" dos diálogos de Macário ou dos episódios de Noite na taverna. Na Lira dos vinte anos e nas Poesias diversas, a falta de unidade das composições não chega a comprometer o alto valor poético de numerosas passagens, das mais ricas de nossa literatura. O registro emocional dos versos brancos de um poema como "Ideias Íntimas" é na realidade bem amplo; a angústia adolescente vagueia de desejo em desejo, fascinada pelas ninfas do álbum romântico (...), dolorosamente lúcida ante a impalpabilidade do "ElDorado de amor que a mente cria", mas nem por isso menos atraída pela mágica sedução da fuga onírica. ${ }^{4}$

A irregularidade formal de Azevedo é também interpretada como produto de sua condição adolescente, hipótese lembrada para ressaltar tanto as suas qualidades quanto os seus defeitos: "Mais do que assíduo leitor, [Álvares de Azevedo] era um devorador de livros, ainda na idade em que a tal apetite não pode corresponder igual capacidade de assimilação", afirma José Veríssimo em seu ensaio sobre o poeta. ${ }^{5}$

\footnotetext{
${ }^{3}$ MERQUIOR, José Guilherme. "Álvares de Azevedo". In: AZEVEDO, Álvares de. Obra completa. BUENO, Alexei (org.) Rio de Janeiro: Nova Aguilar, 2000, p.96. Na edição crítica das Poesias Completas de Álvares de Azevedo, Péricles Eugênio estabeleceu o trecho da seguinte forma: "Frouxo o verso talvez, pálida a rima/ Por estes meus delírios cambeteia,/ Porém odeio o pó que deixa a lima/ E o tedioso emendar que gela a veia”, Cf. AZEVEDO, Álvares de. Poesias completas; edição crítica de Péricles Eugênio da Silva Ramos; Iumna Maria Simon (org), Campinas, SP: editora da Unicamp, São Paulo: Imprensa Oficial do Estado, 2002, p. 312.

4 MERQUIOR, idem, p.97.

5 VERÍSSIMO, José. “Álvares de Azevedo”. In: AZEVEDO, Álvares de, 2000, p. 43.
} 
A avaliação de Jaci Monteiro — um primo de Álvares de Azevedo, e o primeiro responsável por organizar parte de sua publicação póstuma —, reconhece os "defeitos" formais na obra desse escritor, mas as enxerga como produto do "gênio":

Defeitos tem-nos ele por certo, mas inteiramente provenientes da sofreguidão com que escrevia, do pouco tempo que teve para limar e polir o que lhe saíra da fronte escaldada - nessas noites de delírio e de vigílias. Há somente a natureza, somente o lampejo fulgurante do gênio; aquilo que a arte podia fazer, o que competia à reflexão — não lhe deu tempo a voz do arcanjo do extermínio.

Mas como belo é mesmo assim em seus defeitos! Como agrada aquele desleixo, aquele abandono, que às vezes se lhe nota no estilo! (...)

Imaginação de fogo era às vezes demasiado arrojado em suas ideias e em suas opiniões. Para prova aí estão algumas de suas poesias.

Cremos que se o poeta vivesse e tentasse dar-lhe a luz da publicidade, certo que lhes modificaria, não o estilo, que é belo e grandioso, mas o arrojo do pensamento, o arrojo das ideias. ${ }^{6}$

Machado de Assis também comentou o tema do inacabamento na produção alvaresiana, em um texto datado de 1864, e, assim como Jaci Monteiro, lamenta a breve existência do poeta Álvares de Azevedo:

\begin{abstract}
Álvares de Azevedo era realmente um grande talento; só lhe faltou o tempo, como disse um dos seus necrólogos. Aquela imaginação vivaz, ambiciosa, inquieta, receberia com o tempo as modificações necessárias; discernindo no seu fundo intelectual aquilo que era próprio de si, e aquilo que era apenas reflexo alheio, impressão da juventude, Álvares de Azevedo, acabaria por afirmar a sua individualidade poética. Era daqueles que o berço vota à imortalidade. Compare-se a idade com que morreu aos trabalhos que deixou, e ver-se-à que seiva poderosa não existia naquela organização rara. Tinha os defeitos, as incertezas, os desvios, próprios de um talento novo, que não podia conter-se, nem buscava definir-se. A isto acrescente-se que a íntima convivência de alguns grandes poetas da Alemanha e da Inglaterra produziu, como dissemos, uma poderosa impressão naquele espírito, aliás tão original. Não tiramos disso nenhuma censura; essa convivência, que não poderia destruir o caráter da sua individualidade poética; ser-lhe-ia de muito proveito, e não pouco contribuiria para a formação definitiva de um talento tão real. ${ }^{7}$
\end{abstract}

No mesmo texto, Machado de Assis lembra o intenso diálogo alvaresiano com a poesia de Lord Byron, mas ressalta que o poeta inglês não era referência exclusiva nos versos e na prosa do poeta romântico brasileiro. Além de Shakespeare, Machado de Assis cita a inspiração de Azevedo em Musset como um ponto marcante na poética do jovem autor, percebida nos versos de "Boêmios" e de O poema do frade, que Machado

\footnotetext{
${ }^{6}$ MONTEIRO, Jaci. “Álvares de Azevedo”. In: AZEVEDO, Álvares de, 2000, p. 23.

${ }^{7}$ ASSIS, Machado de. "Álvares de Azevedo". In: AZEVEDO, Álvares de, 2000, pp. 24-25.
} 
chama, respectivamente, de "um fragmento acabado" e de "um borrão, por emendar". 8 Para o autor de Memórias Póstumas de Brás Cubas, a prolixidade está mais associada à prosa do que à poesia de Azevedo:

\begin{abstract}
Ensaiou-se na prosa, e escreveu muito; mas a sua prosa não é igual ao seu verso. Era frequentemente difuso e confuso; faltava-lhe precisão e concisão. Tinha os defeitos próprios das estreias, mesmo brilhantes como eram as dele. Procurava a abundância e caía no excesso. A ideia lutava-lhe com a pena, e a erudição dominava a reflexão. Mas se não era tão prosador como poeta, pode-se afirmar, pelo que deixou ver e entrever, quanto se devia esperar dele, alguns anos mais.
\end{abstract}

Na fortuna crítica do poeta estudado, observa-se uma oscilação entre a tentativa de compreender a irregularidade formal de Álvares de Azevedo ora como resultado de sua vida particular, ora como uma herança do romantismo. Alcides Villaça considera que a apreciação da poesia de Azevedo não pode desconsiderar o momento do poeta, possivelmente bastante prejudicado pela publicação póstuma; porém busca relativizar o peso desses dados: "a condição de adolescente e estudante desterrado, a timidez amorosa, o bom berço familiar e as leituras de Byron e Musset não são condicionantes explicativas, mas partes da questão." $\mathrm{O}$ crítico destaca que produção alvaresiana é bastante moderna no uso da ironia, ressaltando a "aguda autoconsciência"11 poética de Álvares de Azevedo:

A funda ironia com que [Álvares de Azevedo] trata o poeta e a própria imagem do artista e as suas mais caras obsessões dá a tudo o sentido de uma confissão ampla, lúcida, acerca da condição frágil do escritor adolescente e sonhador.

De fato, em seus melhores momentos, Álvares de Azevedo exerceu com precocidade uma avaliação crítica dos códigos de sua poesia. (...) Nunca saberemos até onde chegaria seu talento, se vivesse outros vinte anos $(\ldots.){ }^{12}$

O estudioso Roberto de Oliveira Brandão tem parecer semelhante a este:

Se é verdade, como sugere a crítica, que muito dos seus excessos de imaginação e de forma se devem a uma confluência de vários fatores, entre os quais, a fase praticamente adolescente em que produziu sua obra, ou então, a influência da leitura dos românticos europeus, sobretudo o "misterioso

\footnotetext{
${ }^{8}$ Idem, p. 25.

${ }^{9}$ Idem, p. 26.

10 VILLAÇA, Alcides Celso de Oliveira. "Afinação e dissonância”, in: Folha de São Paulo. Jornal de Resenhas, 2002, p. 2313.

${ }^{11}$ Idem. Na intimidade romântica. In: AZEVEDO, Álvares de. Lira dos Vinte Anos. São Paulo: FTD, 1994, p.18.

${ }^{12}$ Idem, pp. 20-21.
} 
Bretão de ardentes sonhos", como o poeta se refere a Byron, o fato é que, pela amplitude de sua produção criativa e crítica — basta lembrar que em poucos anos de atividade fez incursões simultâneas pelos campos da poesia (Lira dos Vinte Anos, Poesias Diversas, O Conde Lopo, O Livro de Fra Gondicário e $O$ Poema do Frade, este último a que Joaquim Norberto chamou de "delírio poético"), do teatro (Macário), do conto fantástico (A Noite na Taverna), dos vários estudos histórico-literários e os discursos acadêmicos, Álvares de Azevedo ocupa lugar de destaque na literatura brasileira do século XIX. E, certamente, mais elevado seria esse lugar se tivesse tido tempo para amadurecer os frutos que sua obra prometia.

Acrescente-se ao aspecto da diversidade dos gêneros com que exerceu seu talento, a aguda consciência que manifesta em relação à divisão da própria poesia. $^{13}$

Antonio Candido chama a atenção para a presença da binomia na produção deste poeta, assim como para os seus estudos literários, exemplos da consciência crítica de Azevedo. A produção do poeta "se apoia em estudos críticos, onde ele exprimiu a sua concepção de literatura com uma consciência teórica que o destaca entre os nossos poetas românticos". ${ }^{14}$ Segundo Candido, a essência do melhor pensamento crítico de Azevedo está no prefácio da segunda parte da Lira dos vinte anos, assentada sobre o princípio da "binomia"; esta, definida como "a coexistência e choque dos contrários, um dos pressupostos da estética romântica". ${ }^{15}$ No entanto, o esforço alvaresiano de destacar o "embate das desarmonias" e superar os limites entre os diferentes gêneros literários teria saído de controle em algumas de suas obras:

A consequência foi que a corda esticou a ponto de rebentar nos escritos de nível inferior, onde o desejo de modular todos os sentimentos costeou o caos psicológico, enquanto o desejo de desrespeitar as normas estéticas tradicionais levou à desorganização do texto. Sob este aspecto, tais escritos inferiores são interessantes para se verificar, pelos casos extremos, certas características da escrita. ${ }^{16}$

No ensaio "Álvares de Azevedo, ou Ariel e Caliban", Candido afirma que, justamente devido a essa desigualdade de resultados observada na poética alvaresiana, "Dentre os poetas românticos, Álvares de Azevedo é o que não podemos apreciar moderadamente: ou nos apegamos à sua obra passando por sobre os defeitos e limitações que a deformam, ou a rejeitamos com veemência, rejeitando a magia que

\footnotetext{
${ }^{13}$ BRANDÃO, Roberto de Oliveira. "Ultrajovem Álvares de Azevedo”, in: Linha D’água, São Paulo: Edusp, n.9, 1995, pp. 23-24.

${ }^{14}$ CANDIDO, Antonio. “A educação pela noite”. In: A educação pela noite e outros ensaios. São Paulo: Ática, 1987, pp.10.

${ }^{15}$ Idem, idem, idem.

${ }^{16}$ Idem, idem, p. 11.
} 
dela emana."17 Essas supostas limitações e deformações revelam, segundo ele, "poemas sem relevo nem músculo, versalhada que escorre desprovida de necessidade artística". Nos ensaios "A Educação pela Noite”, “Álvares de Azevedo, ou Ariel e Caliban”, ou ainda no prefácio a Os Melhores poemas de Álvares de Azevedo, Antonio Candido aponta o núcleo problemático da produção do poeta, condensado no conjunto "byroniano" de sua obra:

A influência de Byron é avassaladora nele, embora coada em grande parte através de Musset, manifestando-se em declarações, citações, epígrafes, pastichos, temas, técnicas, concepção de vida. A ela se misturam as de Shakespeare, Hoffmann, Victor Hugo, os portugueses. Mas a parte estritamente byroniana da sua obra, há pouco citada [O Poema do Frade, $O$ conde Lopo e $O$ Livro de Fra Gondicário], é a mais fraca e artificial. ${ }^{18}$

Parte dos críticos literários brasileiros, mesmo os contemporâneos a Álvares de Azevedo, encararam as "desesperadas tentativas de byronizar" 19 deste último de modo negativo: índice de plágio, de valorização do ambiente estrangeiro em detrimento da realidade local, fruto do entusiasmo de um adolescente ingênuo diante da moda:

Álvares de Azevedo, no círculo estreito da Academia, a "república", os bailes provincianos, as férias na Corte, foi bastante pueril nas três obras acentuadamente byronianas, onde o tom coloquial, a aisance insinuante das digressões do modelo, a sua maestria no jogo dos contrastes, se tornam incoerência palavrosa e sem nexo, com os seus condes e cavaleiros grotescos, as suas mulheres fatais, num artificialismo de adolescente escandescido. No Conde Lopo surgem todos os piores e mais vulgares chavões românticos, com tão pasmosa minúcia, que se poderia aplicar a ele o que disse um crítico americano de outra obra: "é tão má, mas tão má, que quase chega a ser boa." 20

Em “A Educação pela Noite", Antonio Candido chama a atenção para o fato de que as chamadas composições "byronianas" de Azevedo ainda carecem de um estudo satisfatório que aborde as implicações do estilo de Byron na forma empregada. Ao tratá-

17 CANDIDO, 1993, p. 159. Segundo Antônio Candido, os escritos de Álvares de Azevedo "foram reunidos e publicados depois de sua morte em edição que misturou textos acabados, rascunhos, fragmentos, aos quais faltaram a seleção e o polimento do autor (Poesias, 2 volumes, 1853-5). A sua obra é portanto irregular demais e deve ser analisada pelo pouco que tem de melhor". Para esta citação, cf. CANDIDO, Antonio. O romantismo no Brasil. São Paulo: Humanitas, FFLCH, 2004, p.49.

${ }^{18}$ Idem, 1993, p.167-168. A avaliação de Alcides Villaça, em "Afinação e dissonância", é similar: "É possível que algum leitor encontre interesse em momentos de retórica inteiramente submissa aos modelos, como nos versos de O Conde Lopo ou na prosa escolar de O Livro de Fra Gondicário, exemplo de pastiche estilístico. Há quem goste dos contos amarrados de Noite na Taverna, reconhecendo morbidez verdadeira, de traços góticos, onde talvez só haja maneirismo de escritor juvenil”, cf. VILLAÇA, Alcides, 2002, p. 2313.

${ }^{19}$ CANDIDO, Antonio, 1993, p. 167.

20 Idem, pp. 168-169. 
las sob a luz de uma possível "estética da multiplicação", relaciona a estrutura das narrativas de Azevedo ao gosto pelas digressões e pela "frouxidão". ${ }^{21}$ Conforme o crítico explica, a dispersão do discurso romântico se expressa na tentativa de abarcar a variedade e o detalhe como representações da multiplicidade. Atenua-se o esforço de organização da matéria, de modo a priorizar "estruturas vacilantes, com acúmulo de incidências, a-propósitos e digressões, resultado de uma composição em arabesco, extremamente caprichosa, na qual o fio da meada é torcido até se perder". ${ }^{22}$ No caso de O poema do frade, Candido afirma, esse quadro se acentua, sendo difícil até mesmo identificar o assunto do texto em certas passagens, devido ao acúmulo de digressões e confusão das cenas, nas quais "o narrador faz reflexões, medita com extraordinária prolixidade sobre a vida e a morte - e tudo se esfuma na massa informe de versos, alguns dos quais bonitos". ${ }^{23} \mathrm{O}$ autor de Formação da literatura brasileira discute a possibilidade de a construção dessas obras se valer do gênero do fragmento:

(...) é preciso sempre lembrar que as obras de Álvares de Azevedo foram publicadas depois da sua morte, sem que ele tivesse podido organizá-las nem dizer o que considerava acabado, o que era rascunho e o que não era para publicar. Daí a pergunta: esse monte de prosa e verso é tão irregular porque não foi devidamente selecionado e polido, ou porque o Autor queria que fosse assim mesmo, para sugerir a inspiração desamarrada, em obediência a uma estética atraída pelo espontâneo e o fragmentário? É difícil dizer, mas as duas coisas devem estar combinadas. ${ }^{24}$

No entanto, o crítico insiste na hipótese de a irregularidade formal de Azevedo ser decorrência de incapacidade de organização da narrativa, ou da imaturidade juvenil do poeta:

Incapaz na maioria das vezes de dominar a matéria, ele frequentemente não consegue manter a sequência nem articular logicamente os fios do enredo, de tal modo que no exemplo extremo de O Poema do Frade e d'O conde Lopo não se sabe se os personagens que falam agora são os que falavam antes; se as cenas descritas são episódios da mesma sequência ou unidades independentes. Daí o seu ar de fragmento. No entanto, este não parece resultar de uma opção estética, como era frequente entre os românticos, que costumavam usar a composição picada a fim de sugerir a sua concepção do incompleto, do inexprimível; e que os manifestam no tateio estratégico do estilo, na elipse, no subentendido, produzindo uma descrição aproximativa, que procura preservar o ar de mistério. Em Álvares de Azevedo a

\footnotetext{
${ }^{21}$ CANDIDO, Antonio, 1987, pp.20-21.

${ }^{22}$ Idem, p. 21.

${ }^{23}$ Idem, p. 20.

${ }^{24}$ Idem, p. 11.
} 

obscuridade e confusão nas obras secundárias. ${ }^{25}$

Ainda que Antonio Candido sinalize a possibilidade de interpretação do inacabamento e da irregularidade nas produções de Álvares de Azevedo segundo a teoria estética do romantismo, ele salienta, porém, que nos poemas de Lord Byron, a "prolixidade digressiva mais parece capricho de narrador displicente do que incapacidade de organizar". ${ }^{26}$ Dessa maneira, Candido sugere que Byron obteve sucesso em sua experiência poética com o fragmentário, ao passo que Álvares de Azevedo teria fracassado, pois nos "contos metrificados" de inspiração byroniana deste último, verifica-se um

Delírio de caracterização que, na sua prolixidade, sacrifica a ação, pois esta nunca chega a se configurar realmente. Mais do que em Byron ou Musset, em Álvares de Azevedo há uma fuga permanente do assunto, uma espécie de adiamento compulsivo que retira muitos dos seus escritos do âmbito da ficção em prosa ou verso, para reduzi-los a vastas meditações. ${ }^{27}$

A predominância das "vastas meditações" implica uma redução da obra literária, assentada preferencialmente sobre a ação, segundo o ponto de vista acima demonstrado. Por outro lado, as obras "maiores" de Álvares de Azevedo seriam aquelas mais ordenadas, com senso de medida e utilidade: "Na melhor parte de sua obra as palavras se ordenam com medida, indicando que a emoção logrou-se realizar pelo encontro da expressão justa. Infelizmente, porém, há nele uma pesada sobrecarga de versos e prosa vazios, inúteis, revelando indiscriminação artística." 28 Os poemas líricos deste poeta, especialmente aqueles de Lira dos vinte anos, teriam alcançado o ponto alto na produção alvaresiana, marcando os momentos de "maturidade" do poeta adolescente. ${ }^{29}$ A clara delimitação binômica dos poemas líricos se afasta do

(...) fluxo verboso e pedante de quem está querendo escrever segundo os cacoetes da época, inclusive o amor pelo vocabulário rebuscado, num período longo cheio de intercalações, com abundância de imagens e apostos, sem contar o exibicionismo de erudição pela rama. Nos poemas narrativos a incontinência chega a parecer perda de controle, com tal sofreguidão de contar, que o sentido se embaralha e o leitor custa a percebê-lo. ${ }^{30}$

\footnotetext{
${ }^{25}$ Idem, pp.21-22.

${ }^{26}$ Idem, p. 20.

${ }^{27}$ Idem, p. 21.

${ }^{28}$ CANDIDO, Antonio, 1993, p.167.

${ }^{29}$ Idem, pp. 169-170.

${ }^{30}$ CANDIDO, Antonio. "Introdução", in: AZEVEDO, Álvares de. Os melhores poemas de Álvares de Azevedo. São Paulo: Global, 1994, pp.15-16.
} 
Em Os melhores poemas de Álvares de Azevedo, Antonio Candido publicou apenas a primeira parte de Macário por considerá-la uma obra-prima. A exclusão do restante da narrativa deve-se, aos olhos do crítico, ao fato de que ela seria uma realização inferior de Azevedo, distanciando-se da concisão da parte antecedente:

\begin{abstract}
A segunda parte do Macário (...) é inferior sob todos os pontos de vista, a começar pela composição desarticulada em dez cenas sem nexo, duas das quais desprovidas da indicação de lugar.

O início é tão desligado, tão alheio ao resto, que chegamos a pensar ter o Autor querido incluí-lo artificialmente como sobra do universo fantasmagórico. $^{31}$
\end{abstract}

Andrea Werkema discorda do parecer de Candido sobre a segunda parte de Macário, e considera que essa produção se molda inversamente ao seu trecho inicial: suas oscilações e ritmo lento se opõem à estrutura concisa e mais linear daquela. $\mathrm{O}$ desfecho em Macário, no caso, promove deliberadamente a quase implosão da legibilidade da obra, sobre a qual o estilo da primeira parte busca se adequar. ${ }^{32} \mathrm{O}$ julgamento de Werkema, por outro lado, coincide com o de Antonio Candido sobre $O$ livro de Fra Gondicário, segundo o qual este não seria bem-sucedido esteticamente, embora exiba semelhanças com $O$ poema do frade e $O$ conde Lopo. Para ela, $O$ livro de Fra Gondicário "deve ser visto como um primeiro esboço, ou uma tentativa de algo que não chegou a se concretizar". 33

Segundo a autora de Macário, ou do drama romântico, há na poética de Álvares de Azevedo um sistema que promove não apenas uma crítica a outros autores, mas sobretudo à sua própria obra, por meio de um diálogo interno constituído de autoepígrafes, reescrituras e inversões, pautadas pelo movimento em espelho que a binomia promove. Os procedimentos desenvolvidos em seu código poético particular ficam dissimulados pelo efeito de espontaneidade e desregramento, tematizados em muitas obras românticas.

O breve levantamento sobre o tema do inacabamento na obra de Álvares de Azevedo feito nesta introdução aponta as três grandes tendências a partir das quais a fortuna crítica do poeta interpreta a questão. Na primeira delas, o inacabamento é

\footnotetext{
${ }^{31}$ Idem, 1987, p. 13. O juízo de Antonio Candido sobre a primeira parte de Macário se repete em $O$ Romantismo no Brasil, 2004, p.50.

32 WERKEMA, Andrea, Macário, ou do drama romântico em Álvares de Azevedo, 2007, p.132.

${ }^{33}$ Idem, p. 159.
} 
explicado segundo o argumento de que ele é resultado da morte precoce do autor, circunstância que o impediu de revisar e organizar a sua produção. A segunda tendência sugere a condição adolescente do poeta como determinante das dificuldades no manejo da forma poética que ele realiza, bem como da incapacidade de uma construção satisfatória do efeito de unidade em algumas de suas obras. Por fim, a última direção busca conjugar os traços de inacabamento na escrita de Álvares de Azevedo não somente com as circunstâncias pessoais de sua vida, mas com a estética romântica de um modo mais geral.

Também é uma tendência constante na fortuna crítica de Álvares de Azevedo o agrupamento das obras O poema do frade, O conde Lopo e O livro de Fra Gondicário em um conjunto específico de obras supostamente defeituosas. Frente a isso, cabe se perguntar se a impressão de inacabamento, encarada como traço comprometedor do sucesso de cada uma delas, é produzida de maneira uniforme. A segunda parte de $O$ livro de Fra Gondicário, por exemplo, é assentada sobre um enredo truncado, fortemente marcado pela ação de suas personagens. A presença do narrador é mais atenuada, se comparada àquela observada em O poema do frade. O livro de Fra Gondicário apresenta ainda uma abertura problemática, conforme a indicação "Terceira parte" sugere no início da obra —, que será mais detidamente comentado no primeiro capítulo desta dissertação. Em $O$ conde Lopo, de forma diversa, o desfecho é bruscamente interrompido, como se o manuscrito tivesse sido abandonado pelo autor. Por fim, O poema do frade é composto de cinco cantos bem delimitados, sem que haja qualquer numeração lacunar entre eles. Sua impressão de incompletude decorre do andamento digressivo do discurso, movimentado pelo frade-poeta que dá nome à obra. A abertura do poema é longa e confusa; além disso, a demora do enunciador para definir o seu assunto de forma clara e objetiva contribui logo para desestimular seus possíveis leitores. Embora seja afirmado no final do Canto Primeiro que a obra narrará uma epopeia centrada no herói Jônatas, o discurso do enunciador se afasta a todo momento dessa proposta. $\mathrm{O}$ enredo épico não se estabelece nos cantos seguintes, cada vez mais preenchidos por devaneios, meditações, digressões e comentários de ordem metapoética.

A falta de uma linearidade ou mesmo das relações de causalidade no pretenso enredo, além do desenvolvimento insuficiente dado à suas duas únicas personagens, acabam por realçar a sensação de inadequação ao gênero (ironicamente) proposto. Todavia, o título atribuído à obra, $O$ poema do frade, já indica uma dissonância: ao 
fazer referência não ao herói anunciado, mas ao enunciador obscuro que, progressivamente, passa a ocupar o foco do poema, observa-se uma estratégia de quebra de expectativas.

\section{O inacabamento como forma e tema no romantismo}

Deve-se levar em conta que a noção de unidade da obra de arte romântica é teorizada de forma diversa daquela formulada na poética clássica. Outro ponto a ser considerado é a concepção romântica de fragmento como uma forma prevista e esteticamente válida. O fragmento, no entanto, não se reduz a um rascunho qualquer. Segundo explica Walter Benjamin, em $O$ conceito de crítica de arte no romantismo alemão, ele está a meio caminho da obra realizada e da obra imaginada, ou da obra inacabada e inacabável. ${ }^{34}$ Nesta perspectiva, a incompletude da obra de arte não resulta de imperícia e acidentes, mas alude a uma representação maior, que aponta para um processo em devir, todavia inalcançável em sua plenitude. Sem a sua contraparte ideal e reflexiva, as marcas da incompletude se afastam do gênero do fragmento. A fragmentação implica a aguda consciência dos limites da forma, e reconhece na crítica o instrumento para a compleição da obra de arte fragmentária. ${ }^{35}$ No imaginário romântico, as noções de "defeito" e "fracasso" demandam uma abordagem cuidadosa. Assim como o valor conferido à presença das "vastas meditações" no julgamento de uma obra poética.

No ensaio "O texto definitivo", Charles Rosen explica que o romantismo defendia a crença em uma força primordial e essencial presente nos primeiros rascunhos poéticos. Esse posicionamento artístico se ampara na ideia de que a obra de arte possui uma "lógica e até uma espécie de vontade de potência próprias" 36 , cujo funcionamento não é completamente explicável para o artista, uma vez que "a verdadeira obra de arte brota da mente inconsciente plenamente formada". ${ }^{37}$ Rosen cita casos retirados de textos de Lord Byron e de William Wordsworth, nos quais as versões corrigidas se revelam visivelmente abaixo dos esboços preliminares, com sensível piora, tornadas tão apenas

\footnotetext{
${ }^{34}$ BENJAMIN, Walter. O conceito de crítica de arte no romantismo alemão. São Paulo: Editora Iluminuras, 1999, p. 32.

${ }^{35}$ Idem, pp.92-93.

${ }^{36}$ ROSEN, Charles. "O texto definitivo". In: Poetas românticos, críticos e outros loucos. Tradução José Laurênio de Melo. São Paulo: Ateliê Editorial; Campinas: Editora Unicamp, 2004, p.40.

${ }^{37}$ Idem, idem, p. 15.
} 
um produto mais "domesticado" pela razão. Diante da experiência romântica, Rosen indaga se a versão final do autor tem necessariamente mais autoridade do que as variantes anteriores dos textos.

Segundo ele, no século XVIII houve um imenso empenho direcionado ao estabelecimento de textos definitivos de obras clássicas, resultado de rigorosas pesquisas cuja meta era a fixação de um sentido único e final em edições críticas. A tendência romântica, por sua vez, foi considerar versões e variantes de uma mesma obra como textos distintos e de certa forma independentes. Por isso, lançar uma nova edição crítica contribuiria não para conferir unicidade, mas para multiplicar outras tantas novas versões. Cada uma delas, particularmente, se coloca como obra aberta, podendo ser acrescentada, continuada, mas nunca terminada. Rosen chega a dizer que certas versões e revisões românticas se tornam tão radicalmente diferentes que não é sequer possível dizer que se trata de uma mesma obra.

É interessante notar que, dentre os poetas privilegiados na análise de Charles Rosen em sua reflexão sobre o inacabamento no romantismo, o estudioso cite especialmente Lord Byron, conhecido pelo processo de escrita profusa. Mais acima neste capítulo comentou-se a respeito das diversas maneiras como o inacabamento, associado à poética de Álvares de Azevedo, foi interpretado em sua fortuna crítica, que destacou a sua relação com o byronismo para se pensar a questão. O diálogo de Azevedo com o estilo de Lord Byron, conforme pôde-se observar nas avaliações expostas neste capítulo, é encarado de maneira negativa e apontado como elemento comprometedor de suas chamadas "obras menores". Estas, inclusive, são chamadas de "conjunto byroniano" da produção alvaresiana.

É também recorrente na fortuna crítica do poeta em estudo o julgamento segundo o qual o "byronismo" de Álvares de Azevedo deva ser entendido como um exemplo de falta de originalidade do poeta brasileiro diante de uma "moda" celebrada por adolescentes novecentistas. A estudiosa Karin Volobuef, por sua vez, procura encarar o fenômeno internacional do byronismo dentre as gerações do início do século XIX de maneira mais generosa. Suas considerações partem do estudo de Onédia Barboza, que se dedicou a pensar as traduções de Byron no romantismo brasileiro. Segundo Barboza, nem toda a obra do poeta inglês foi priorizada em solo local; há uma visível e sugestiva seleção dentre os textos byronianos escolhidos, que deve ser levada em consideração. Percebe-se nas traduções brasileiras uma "propensão de tornar os 
textos de Byron mais sombrios e mórbidos do que no original" ${ }^{38}$, ou seja, seus versos sofreram profunda modificação de acordo com as inclinações estilísticas do tradutor local, em uma relação de apropriação e recriação que evidencia, antes, o reforço de sua própria sensibilidade e estilo, sem grande preocupação com uma suposta fidelidade à "verdade" do texto de partida. Por isso, pode-se dizer que houve uma intensificação de determinados traços da poética byroniana no Brasil, tornando-a ainda mais melancólica e sentimental do que originalmente foi concebida por Lord Byron: byronizou-se o próprio Byron, não conforme o poeta supostamente era, mas de acordo com a maneira como fora entendido e celebrado em terras brasileiras ${ }^{39}$ : um poema de Byron "suficientemente byroniano" pressupunha necessariamente um "toque alvaresiano", encontrado nas traduções locais do poeta inglês. Esse "toque alvaresiano" geralmente foi identificado com certa melancolia pessimista em cujas tintas se misturam também ressonâncias do diálogo do poeta brasileiro com Musset, Lamartine e mesmo com o sentimentalismo goethiano e pré-romântico de Werther. ${ }^{40}$ Karin Volobuef ressalta que se o byronismo

\begin{abstract}
se espalhou rapidamente pelo mundo, contagiando as gerações do início do século XIX, isso se deve ao fato de a atitude pessoal de Byron e seu ideário estético - fundados no sentimento de melancolia, na postura cética e sarcástica ante o convencionalismo e a tradição, no culto à morte, na inconstância e permanente insatisfação - produzirem uma ressonância em outros lugares em vista da situação vivida pelos seus jovens poetas. Em outras palavras, Byron não "virou moda" simplesmente ou foi "imitado" às cegas; sua repercussão ocorreu em razão da resposta que deu a questões vivas e pertinentes a outros países, cujos poetas se identificaram com o lorde inglês e viram nele uma forma de lidar com sua própria realidade, com seus próprios anseios e inquietações, sua própria revolta e desilusão. ${ }^{41}$
\end{abstract}

Para Karin Volobuef é necessário ponderar sobre as circunstâncias que tornaram o Brasil um "solo fértil para o byonismo" e "de que maneira ele vinha ao encontro dos conflitos e questões que ali haviam surgido". ${ }^{42}$ Neste sentido, pode-se pensar que a relação de Azevedo com a obra de Byron "não bloqueou, antes fortaleceu, as tendências específicas do poeta brasileiro". ${ }^{43}$ Como já se disse mais acima, os poetas e tradutores nacionais selecionaram apenas uma parte da obra de Byron em suas traduções, "aquilo

\footnotetext{
${ }^{38}$ VOLOBUEF, Karin. Frestas e arestas: a prosa de ficção do romantismo na Alemanha e no Brasil. São Paulo: Fundação Editora da UNESP, 1998, p. 24.

${ }^{39}$ Idem, idem, p.246-247.

${ }^{40}$ Idem, idem, p.413.

${ }^{41}$ Idem, idem, p.23.

${ }^{42}$ Idem, idem, p. 24

${ }^{43}$ Idem, idem, idem.
} 
que mereceu preferência era o que continha realmente um significado para os brasileiros da época; o restante não mereceu a atenção deles por não ter conexão com seu próprio campo de interesses". Essa postura ativa na seleção do material traduzido e citado enfraquece a relação entre "simples servilhismo e falta de originalidade ou inspiração", muitas vezes associados ao chamado ultrarromantismo brasileiro. ${ }^{44}$

$\mathrm{Na}$ fortuna crítica de Álvares de Azevedo, houve quem encarasse as misturas e "extravagâncias" "byronianas" presentes no estilo do poeta de modo mais positivo. Ronald de Carvalho, por exemplo, mostra-se empolgado com elas em O poema do frade: "Das suas teorias literárias é o Poema do Frade, mescla disparatada de formosos atrevimentos e audaciosas extravagâncias, o documento profundo e admirável". ${ }^{45}$ Joaquim Norberto também não se intimida diante dos excessos e confusões desta obra: “O seu Poema do Frade é um delírio poético, com um título incompreensível, imitação do Don Juan de Byron, sonho de uma noite de insônia, motivada pelo spleen, devido às convulsões da ironia e no qual figuram trechos lindíssimos". ${ }^{46} \mathrm{O}$ entusiasmo percebido nas palavras de Joaquim Norberto não arrefece diante da alegada incompreensibilidade, do "delírio" e da forte relação da obra alvaresiana com a escrita de Byron. Na realidade, esses elementos figuram como uma qualidade na perspectiva de Norberto.

A tendência à grande quantidade de citações a outros autores por meio de epígrafes e outros artifícios, não só em $O$ poema do frade, mas em toda a produção de Álvares de Azevedo, insere-se na perspectiva do esforço romântico de ampliar a obra de arte individual até o ideal encarnado na imagem de um grande livro total: à maneira da poesia antiga, a literatura moderna deve ser um grande conjunto, uno, completo. Visto que é impossível recuperar a unidade e a harmonia da arte antiga (ingênua), a poesia romântica busca criar artificialmente uma nova arte, formada pela reaproximação das poesias ingênua e sentimental, simultaneamente. No entanto, esta síntese perfeita nunca será alcançada. O artista romântico é consciente da utopia de seu ideal e de sua tarefa inacabável: a superação de uma distância infinita entre os contrários.

A escrita marcada pelo inacabamento aproxima $O$ poema do frade das preocupações estéticas de Lord Byron, encarado por Álvares de Azevedo como um dos maiores poetas a plasmar o "espírito do século", criando uma paradoxal "Ilíada"

\footnotetext{
${ }^{44}$ Idem, idem, p.24-25.

${ }^{45}$ CARVALHO, Ronald de. "Álvares de Azevedo (1831-1852) e a poesia da dúvida", in: Obra completa, 2000, p. 51. A estrofe citada é a XXIII, do Canto Primeiro.

${ }^{46}$ SOUZA, Joaquim Norberto de. "Álvares de Azevedo visto por alguns críticos e historiadores literários", in: AZEVEDO, Álvares de. Noite na taverna. Organização de Hildon Rocha. Rio de Janeiro: Livraria Francisco Alves, 1991, p. 16.
} 
moderna em seu Childe Harold, conforme o autor de Macário expõe em obras literárias e ensaios, que ampararão a análise de $O$ poema do frade nesta dissertação. Tanto Álvares de Azevedo quanto Byron, por sua vez, estabelecem um diálogo com muitos outros autores modernos, também dedicados a pensar soluções formais propostas em seu tempo para representar a "modernidade" e seus conflitos.

\section{Roteiro do trabalho}

A presente dissertação estrutura-se em quatro capítulos. No primeiro deles, denominado "Dissolução do prólogo", busca-se refletir sobre o uso que Álvares de Azevedo faz do exórdio no romantismo, distanciando-o do modelo do prólogo de tradição neoclássica. A partir da análise do Canto Primeiro de $O$ poema do frade, é introduzido o tema da impossibilidade do gênero da epopeia na modernidade, destacando o trabalho de desconstrução formal e temática do gênero em questão e o debate sobre a concepção de unidade da obra de arte no interior dela mesma.

O capítulo II, "O livre perambular da imaginação", aprofunda a análise da digressão miscelânica como procedimento por meio do qual o narrador pode realizar a sua reflexão metapoética no interior de sua narrativa. Seu discurso devaneante e digressivo é movimentado pela recorrente exploração de imagens de objetos errantes, tais como navios que se deslocam sobre águas oscilantes, a fumaça semelhante a arabescos evanescentes e que se espalha livremente pelo ar, a bebida efervescente e sua relação com a fantasia criadora. O vínculo dessas metáforas com o discurso digressivo e miscelânico é próprio do estilo sublime, repleto de contrastes e desproporções, por meio do qual se procura criar o efeito de simultaneidade entre a ideia e o ato criativo. $\mathrm{O}$ conjunto de imagens elencadas, ainda, favorece a mimetização do processo reflexivo do artista durante o seu ato criador, visível no esforço do poeta em descrever a contemplação de seu próprio pensar.

"Falência da epopeia" é o terceiro capítulo da dissertação, e insere-se mais propriamente no debate romântico sobre a impossibilidade da epopeia na modernidade. Compara-se o modelo do herói épico tradicional — dotado de fé, engajado nas lutas de seu tempo e elevado à altura do mito - , com os tipos de personagens apresentadas em O poema do frade: o poeta libertino e descrente, a prostituta e seu amor venal, e o frade enclausurado. Os dois primeiros encontram-se em conflito com a realidade circundante, 
que nivela e rebaixa prosaicamente todos os valores às trocas mercadológicas; o frade, por sua vez, isola-se e perde o caráter bélico e missionário, tal como se revelava nos antigos membros do clero, figuras nas quais coincidiam o guerreiro e o sacerdote. A ambientação de $O$ poema do frade em uma realidade semelhante a uma longa noite tormentosa e repleta de ruínas é discutida com o amparo de observações tecidas por Azevedo em outras obras e ensaios de sua autoria. Além dele, recorre-se aos apontamentos tecidos por Alexandre Herculano a respeito do sujeito fraturado na modernidade, tomado pela dúvida e pela desconfiança perante os acontecimentos de seu tempo. Nele, já não é mais possível a crença em uma unidade harmônica entre a cruz e a espada, ou entre o estado e a igreja, unificados por um destino comum ditado pela Providência. O relativismo e o pessimismo, bem como o isolamento e a pequenez experimentados no cotidiano burguês - restrito ao espaço privado do lar ou da divisão do trabalho — são incompatíveis com a elevação e o maravilhoso necessários à existência da epopeia. Frente a essas questões, são introduzidas as críticas que Álvares de Azevedo, Alexandre Herculano, José de Alencar e Gonçalves Dias teceram a respeito do projeto de composição de uma epopeia nacional, patrocinada pela política imperial brasileira.

Por fim, o quarto e último capítulo, "Ecos do poeta solitário", continua a analisar a insistência no tema da solidão do narrador em $O$ poema do frade, responsável por instaurar um auditório interno como saída formal encontrada diante da crise da narrativa antiga de modelo oral, a crise também dos valores comunitários e a fragmentação e o isolamento modernos, que tornam problemática a comunicação com um auditório coletivo, tal como o narrador épico o concebia: sua fala era dirigida às multidões unidas por um mesmo sentimento e confiança em um conjunto de valores imemoriais bem definidos. Sem contar com essas condições, o narrador moderno passa a subjetivar as formas segundo a sua perspectiva condicionada pelo relativismo: a ação descrita é aquela ocorrida em seus processos de pensamento; o assunto possível é o "eu". Frente ao esfacelamento da antiga ordem da realidade e da representação mimética tradicional, voltada à exteriorização e à ação objetiva, o eu projeta um horizonte de morte, dissolução e silêncio. Estes últimos elementos são formulados em um discurso devaneante, onírico e especulativo, repleto de imagens musicais que revelam o esforço do narrador em apreender a realidade conflituosa e explorar o mistério que ainda resiste para além do mundo racionalizado e esvaziado pela ordem burguesa. O poema é 
encerrado no Canto Quinto, mas essa busca do narrador permanece inconclusa, em aberto. 


\title{
Capítulo I
}

\section{Dissolução do prólogo}

\begin{abstract}
Um bom prefácio tem de ser, ao mesmo tempo, a raiz e o quadrado do livro.
\end{abstract}

Friedrich Schlegel, Lyceum. $^{47}$

\section{Prelúdio dissonante}

O Canto Primeiro de O poema do frade abre-se com estrofes irregulares e abruptas, que alternam constantemente diversos assuntos e estilos, encadeados de maneira pouco linear. Com tal estruturação, o canto de abertura gera a impressão de desnorteamento e confusão, e adia a percepção do tema maior da obra: a revisão da tradição da epopeia na Modernidade, e da própria poética de Álvares de Azevedo. O poema citado é conduzido por um narrador profundamente irônico, responsável por difundir falsas afirmações em seu discurso, sempre marcado pela digressão e pela reflexão. Por volta da metade do Canto Primeiro, ele declara a pretensão de narrar uma epopeia centrada na personagem Jônatas, proposta em consonância com a rígida estrofação em oitava rima e versos decassílabos presentes nos Cantos Primeiro e Segundo —, ou seja, segundo a forma consagrada pela tradição da epopeia, observada em composições como Os Lusíadas, de Luís Vaz de Camões, ou em Caramuru, de Santa Rita Durão, por exemplo.

A adequação aos fundamentos do gênero da epopeia em $O$ poema do frade, no entanto, cessa por aí. Diferente dos poemas heroicos de tradição clássica e neoclássica, esta obra não narra os feitos bélicos de um herói célebre, no auge de uma civilização; há, por outro lado, a caracterização de uma personagem solitária, marginalizada, e que sucumbe a uma realidade hostil à poesia. Até mesmo o título do poema alvaresiano em questão, inclusive, não remete ao nome de um herói exemplar, representante da coletividade ou da unidade nacional. Vale notar que Joaquim Norberto se referiu a $O$

\footnotetext{
${ }^{47}$ SCHLEGEL, Friedrich. "Lyceum", in: O dialeto dos fragmentos. Tradução, apresentação e notas de
} Márcio Suzuki. São Paulo: Iluminuras, 1997, p. 21. 
poema do frade como "um delírio poético, com um título incompreensível" ${ }^{48}$ A escolha do título no poema de Álvares de Azevedo, ao remeter ao narrador e não ao herói, é irônica na medida em que desloca o foco das ações e acontecimentos objetivos, centrados em uma personagem — como é próprio do gênero épico —, para a tematização do ato criativo e para a interioridade do artista, cada vez mais isolado no mundo moderno. A solidão, o silêncio e a morte são temas constantes não só em $O$ poema do frade, mas em toda a poética de Álvares de Azevedo, na qual se percebe a sistemática tematização do processo de subjetivação das formas, e a assimilação de um auditório interiorizado, gerado pelo movimento incessante de uma consciência irônica, que se desdobra em diferentes direções. O artista afirma, refuta, critica e experimenta as variadas perspectivas de uma mesma obra de arte, buscando assimilar poesia e teoria em um único espaço textual. Daí o caráter ensaístico, de meditação contínua e inacabada de algumas obras românticas, aspecto que proporciona as condições para que Álvares de Azevedo teça em $O$ poema do frade uma revisão do gênero da epopeia e também faça um balanço de sua própria poética, conforme afirmado mais acima neste capítulo.

A variedade e a descontinuidade de temas e estilos em $O$ poema do frade são unificadas pela figura do frade-artista, inicialmente empenhado em negar as suas intenções e confundir o leitor no Canto Primeiro:

\footnotetext{
Prometi um poema, e neste dia Em que tanto obriguei a minha ideia Não prometi por certo a biografia Do sublime cantor desta epopeia. Consagro a outro fim minha harmonia.... Por favor cantarei nesta Odisseia De Jônatas a glória não sabida.... Mas não quero contar a minha vida. ${ }^{49}$
}

O que se vê nos cinco cantos do poema é uma permanente fuga do suposto assunto principal, e a sistemática dissolução dos fundamentos da epopeia. O narrador se propõe a realizar o irrealizável, ao decidir celebrar a "glória não sabida" de um herói marginalizado, afastado das guerras e da política de seu tempo, e que morre precocemente, ainda na metade do poema, que tem continuidade sem a presença dele.

\footnotetext{
${ }^{48}$ NORBERTO, Joaquim. "Álvares de Azevedo visto por alguns críticos e historiadores literários", in: AZEVEDO, Álvares de. Noite na taverna. Organização de Hildon Rocha. Rio de Janeiro: Livraria Francisco Alves, 1991, p.16.

49 AZEVEDO, Álvares de. "O poema do frade", in: Álvares de Azevedo: poesias completas. Edição crítica de Péricles Eugênio da Silva. Campinas: Editora da UNICAMP; São Paulo: Imprensa Oficial, 2002, estrofe XXXIV, p. 315.
} 
$\mathrm{Na}$ pena do autor ficcional criado por Álvares de Azevedo, o canto de abertura se converte em um prólogo neoclássico às avessas. Segundo o modelo convencional do exórdio de epopeia, os dados gerais e a finalidade do poema devem ser resumidos de maneira sucinta e objetiva, logo nos primeiros versos de abertura, preparando o leitor para a narração, encadeada logo a seguir. ${ }^{50}$ Porém, somente na estrofe XXXIV, a penúltima do Canto Primeiro de $O$ poema do frade, é que se apresenta o prólogo, com o anúncio de seus supostos assunto principal, finalidade, gênero, e a apresentação do herói, ali nomeado, criando a expectativa de narração dos feitos bélicos à maneira do que ocorre na Odisseia, citada no trecho acima.

Pode-se dizer que a proposição de $O$ poema do frade se estrutura de trás para frente: as informações essenciais de um prólogo de tradição neoclássica são deslocadas no Canto Primeiro, sendo jogadas para o seu final. O confuso e disforme canto de abertura, aliás, só é explicitamente definido como tal em sua última oitava: "Basta! Foi longo o prólogo! confesso!". ${ }^{51}$ Em outras palavras, define-se o prolixo Canto Primeiro em sua estância final; em uma estrofe imediatamente anterior, o suposto assunto principal do poema é mencionado pelo narrador, de forma apressada e vaga, sintetizada em dois versos apenas: "Por favor cantarei nesta Odisseia/ De Jônatas a glória não sabida...". O desenvolvimento do perfil do herói aparece antes destas informações, na altura da vigésima quarta estância.

Como se vê, a linearidade da proposição tradicional se embaralha no Canto Primeiro de $O$ poema do frade. A dificuldade em estabelecer um encadeamento convencional é ainda potencializada pelas variadas reflexões, digressões e devaneios do narrador a respeito dos gêneros literários, sobre o seu estilo misto, sua relação com o público, sua concepção de herói ou sua visão sobre o tempo presente. O discurso no poema é estruturado segundo a representação do livre fluir de suas meditações, como se as associações e mudanças bruscas de assuntos e tons fossem espontâneas ou aleatórias durante o processo do pensar. ${ }^{52}$

O conjunto de assuntos variados, mencionado acima, é distribuído no Canto Primeiro sem respeitar uma linearidade ou uma hierarquia convencional. Ao inserir na narrativa as digressões de ordem metapoética, tradicionalmente discutida em prefácios

\footnotetext{
${ }^{50}$ LYRA, Pedro. "Roteiro para uma leitura de Jerusalém Libertada", in: TASSO, Torquato. Jerusalém Libertada. Rio de Janeiro: Topbooks/ Centro Universitário da Cidade, 1998, p. 33.

51 AZEVEDO, Álvares de, 2002, estrofe XXXV, p. 315.

52 ALVES, Cilaine. O belo e o disforme: Álvares de Azevedo e a ironia romântica. São Paulo: EDUSP/FAPESP, 1998, p. 169.
} 
ou posfácios teóricos, Álvares de Azevedo entra em consonância com a proposta romântica de abolição das fronteiras entre a reflexão teórica e a obra de arte em si; devese fazer poesia sobre a poesia, conforme afirma Friedrich Schlegel:

A poesia romântica é uma poesia universal progressiva. Sua destinação não é apenas reunificar todos os gêneros separados da poesia e pôr a poesia em contato com filosofia e retórica. Quer e também deve ora mesclar, ora fundir poesia e prosa, genialidade e crítica, poesia-de-arte e poesia-de-natureza, tornar viva e sociável a poesia, e poéticas a vida e a sociedade, poetizar o chiste, preencher e saturar as formas da arte com toda espécie de sólida matéria para cultivo, e as animar pelas pulsações do humor. ${ }^{53}$

Ou ainda:

Poesia só pode ser criticada por poesia. Um juízo artístico que não é ele mesmo uma obra de arte na matéria, como exposição da impressão necessária em seu devir, ou mediante uma bela forma e um tom liberal no espírito da antiga sátira romana, não tem absolutamente direito de cidadania no reino da arte. ${ }^{54}$

Sob o prisma da teorização da arte no tecido do próprio objeto artístico, pode-se abordar os versos, à primeira vista aleatórios, que abrem Canto Primeiro de O poema do frade:

I

Eia! acorde-se a gloria aos meus lamentos

Com as faces de sangue salpicadas!

Tremam nos cantos meus da lide aos ventos

As gotejantes lúcidas espadas!

Revolvam-se raivando macilentos

Os cavaleiros das nações passadas!

Brilhem as multidões ao sol ardente

Com as nuvens douradas do poente!

\section{II}

Nessas lívidas mãos rompa-se a lira!

Além canções cheirosas como o nardo

Que nos festins da noite o vinho inspira!

${ }^{53}$ SCHLEGEL, O dialeto dos fragmentos. Trad. Márcio Suzuki. São Paulo: Editora Iluminuras 1997, p. 64.

${ }^{54}$ Idem, idem, p.38. Schlegel desenvolve o tema também em Conversa sobre a poesia: Não é preciso que alguém se empenhe em obter e reproduzir a poesia através de discursos e doutrinas racionais, ou mesmo produzi-la, inventá-la, estabelecê-la e fornecer-lhes leis punitivas, como seria do agrado da teoria da arte poética. Assim como o coração da terra se reveste de plantas e formas, assim como a vida brotou por si mesma das profundezas e tudo tornou-se pleno de criaturas que alegremente se multiplicavam, assim também brota espontânea a poesia da força primeva e invisível da humanidade, quando o cálido raio do sol divino a atinge e fecunda. Somente as formas e as cores podem expressar, em cópia, como o homem é constituído; e de poesia, também, só se pode falar em poesia. Todo ponto de vista a seu respeito será verdadeiro e bom, na medida em que for, também ele, poesia. In: SCHLEGEL, Friedrich. Conversa sobre poesia e outros fragmentos, Tradução, prefácio e notas: Victor-Pierre Stirnimann, São Paulo, Iluminuras, 1994, p.30. 
Não vedes que da guerra aos sonhos ardo?

Não vedes que meu cérebro delira

E arqueja em fogo o coração do bardo,

E como um rei trocara o meu laurel,

Meu reino - por um ferro e um corcel?

\section{III}

Como das grutas de Fingal na bruma

Do norte a ventania se derrama;

Como roda o tufão no mar que espuma;

Como a cratera do vulcão se inflama;

Como a nuvem de fogo no ar se apruma

Assim no peito meu o estro em chama

Agita-me, afogueia o peito langue

E como as águias, só anela sangue!

\section{IV}

Mas em que mar cavado eu me perdia!

De errante pescador leve canoa,

Que rajada nas águas te impelia

Por entre essa tormenta que reboa?

Minha alma é um balão: na calmaria

Boia plácido no ar, gentil se escoa,

Embala-se voando molemente,

Mas teme a trovoada que o rebente!

A primeira estrofe introduz elementos convencionados ao gênero épico: as exclamações bélicas evocam a "glória", o "sangue" e as "espadas", além das imagens de cavaleiros antigos e de "multidões ao sol ardente". Todavia, o gênero épico, caracterizador dos primeiros versos, cede lugar à lírica, na passagem para a estrofe seguinte. A "lira", as "canções cheirosas" e a noite festiva, inspirada pelo vinho, passam a ocupar o foco do poema. A estrofe III marca novamente uma brusca mudança de assunto, e elenca imagens sublimes de violentos fenômenos naturais, como "a ventania", "o tufão", o "vulcão" inflamado, caracterizadores da força do impulso criativo. ${ }^{55}$ Porém, a quarta estância apresenta as imagens de um frágil balão e de uma canoa, em seu delicado deslizar sobre as águas, antecedidas, não por acaso, pela conjunção adversativa "mas", que marca a sistemática oscilação entre polos contrários. Logo na estrofe II, o eu poético já havia destacado a brusca alternância entre a épica e a lírica como um procedimento caracterizador de seu estilo: "Não vedes que da guerra aos sonhos ardo?/ Não vedes que meu cérebro delira/ E arqueja em fogo o coração do bardo". Logo a seguir, na mesma estrofe, é feita referência à tragédia shakesperiana Ricardo III, na qual a personagem homônima propõe a famigerada troca de todo o seu reino por um cavalo; tal como o rei tirano, movido por seu característico humor

\footnotetext{
${ }^{55}$ ALVES, Cilaine. O belo e o disforme: Álvares de Azevedo e a ironia romântica, 1998, p. 170.
} 
oscilante, o enunciador de $O$ poema do frade salta de um estilo a outro, ao sabor do fogo e do delírio de sua imaginação.

O mesmo esquema se repete nas duas oitavas posteriores; a primeira delas é ocupada por novas imagens violentas (o "corcel selvagem", incontrolável na "peleja" e nos "espinhos"), substituídas na estância seguinte pela "lira mimosa":

$\mathrm{V}$

Ólá sofreia-te, corcel selvagem!

Por que banhas-te em sangue entre a peleja

E nos espinhos roças da folhagem?

Não vês o tressuar que te poreja

No abafado calor dessa bafagem?

Não sentes que a peituga te lateja?

E a onda louca da sanguenta raiva

As tuas crinas cândidas enlaiva?

\section{VI}

Além! além! e tu, lira mimosa,

— Que do lago nas selvas esquecida

Eu votei a uma fada vaporosa

Que nas folhas estende-se dormida. -

Vem, minha lira, canta-me saudosa

Alguma nênia pálida, sentida,

Algum sonho que as folhas balouçando

Te gemesse nas cordas expirando! $!^{56}$

Aos poucos, é possível perceber nessas seis estrofes iniciais uma sistemática oscilação entre os registros épico, nas oitavas ímpares, e lírico, nas oitavas pares. No interior delas, combina-se, de modo disperso, uma reflexão acerca do fazer poético, como se aquele que escreve contemplasse o movimento pendular de seu pensamento. Como já fora mencionado mais acima, a alma do eu lírico é comparada a uma "leve canoa" e a um balão, que se deixam levar pelo movimento das águas e dos ventos (estr. IV). Tal como os objetos citados, o enunciador percorre os diferentes gêneros, mas não se fixa em nenhum deles.

Cilaine Alves Cunha analisou a alternância de estilos poéticos nas estrofes iniciais de $O$ poema do frade segundo a teoria do poema miscelânea. Para a estudiosa, o foco narrativo desta obra de Álvares de Azevedo remete ao modelo digressivo do "narrador-cavaleiro andante", adotado por Lord Byron. Este modelo mimetiza o processo do pensar em movimento, ao registrar as idas, vindas, recuos e pausas da reflexão do narrador. Tal como o cavaleiro byroniano Child Harold, o narrador digressivo de O poema do frade "peregrina" "pelos terrenos dos diversos gêneros

\footnotetext{
${ }^{56}$ AZEVEDO, Álvares de. "O poema do frade”, 2002, pp. 307-308.
} 
literários" ${ }^{57}$ O poema narrativo em questão sugere "a tese do ato criativo como aventura de um narrador titânico". A autora aponta nas imagens bélicas presentes na estrofe inicial (como as "lúcidas espadas") a concepção do fazer poético como batalha, cuja finalidade é "provocar uma reviravolta na tradição" literária. Alves aponta, ainda, os "traços, ainda que frouxos, de um prefácio", no Canto Primeiro de O poema do frade: o narrador discute o gênero de sua obra e dialoga constantemente com a crítica literária, ao tecer uma "defesa prévia" de sua proposta experimental, já sinalizando o possível estranhamento ou mesmo a reprovação que a leitura de seu poema poderia despertar no público. ${ }^{58} \mathrm{~A}$ forma maleável e mista do gênero poema miscelânea permite a livre movimentação do narrador, capaz de articular, assim, os mais variados assuntos e estilos em um mesmo texto. Por isso, Cilaine Alves afirma que "a atenção a esse gênero se torna quase imprescindível para uma melhor compreensão da obra de Álvares de Azevedo". 59

Vale pensar o motivo que teria levado o autor citado a optar pela forma do poema miscelânea e não a de outro gênero maleável e romântico por excelência: o romance. Se por um lado, Azevedo explora a multiplicidade e os saltos bruscos na maneira como seus assuntos são conduzidos na narração, por outro lado conserva, curiosamente, uma estrofação regular (oitavas, nos dois primeiros cantos, e sextilhas nos três cantos finais) durante todo o poema. $\mathrm{O}$ uso das formas fixas funciona como uma espécie de citação à forma da epopeia, e a decisão de manter a "forma velha" sinaliza a opção irônica de representar o processo de implosão das formas tradicionais a partir delas mesmas, por meio do desmonte de suas bases. Nesse sentido, o poeta promete uma epopeia que não pode ser realizada. Essa hipótese será desenvolvida nos capítulos seguintes desta dissertação, pois demanda uma discussão mais detida sobre a visão de mundo contemporâneo na poética alvaresiana. ${ }^{60}$

No Canto Primeiro, o narrador de O poema do frade não deixa claro quem é ou qual é o seu intento, ampliando essa indeterminação para suas personagens, cuja apresentação aos leitores também se retarda. São tecidos comentários sobre o herói a partir da estrofe XXIV deste canto; nas seis estrofes seguintes a ela, discorre-se acerca

\footnotetext{
${ }^{57}$ ALVES, Cilaine. O belo e o disforme: Álvares de Azevedo e a ironia romântica, 1998, p. 169.

${ }^{58}$ Idem, idem, p. 171.

${ }^{59}$ Idem, idem, p. 172.

60 A composição em oitava rima dialoga diretamente com o modelo da epopeia, ao passo que a forma em sextilha não foi tão exaustivamente explorada pela fortuna crítica alvaresiana. O capítulo III da presente dissertação investigará algumas hipóteses sugeridas pela poética do autor e pela fortuna crítica do poeta a respeito da sexta rima, uma vez que o diálogo com as formas tradicionais insinua-se como um ponto essencial para a estruturação de uma leitura de $O$ poema do frade.
} 
da visão de mundo rebelde e o a conduta hedonista do herói, sem contudo fornecer algum dado concreto sobre a sua aparência física. Vale notar que o nome da personagem só é revelado na penúltima estrofe do Canto Primeiro, trecho onde se aglutina uma série de informações essenciais de um prólogo de epopeia, tais como o assunto, a finalidade, o gênero, a apresentação do herói, já citada mais acima neste capítulo. A seguir, não se desenvolve o poema narrativo: o difuso e prolixo Canto Primeiro é bruscamente encerrado, ao ser definido só então como "prólogo" do poema:

\author{
XXXV \\ Basta! foi longo o prólogo! confesso! \\ Mas é preciso à casa uma fachada, \\ À fronte da mulher um adereço, \\ No muro um lampião à torta escada! \\ E agora desse canto me despeço \\ Com a face de lágrimas banhada, \\ Qual o moço Don Juan no enjoo rola \\ Chorando sobre a carta da espanhola. ${ }^{61}$
}

Verifica-se uma evidente desproporção entre o espaço exíguo ocupado pelas informações essenciais de um prólogo tradicional de epopeia, relegadas a um "último lugar", e proferidas apressadamente nas duas estrofes finais do Canto Primeiro, e aquele ocupado pelas digressões no mesmo canto. A caracterização da personagem principal também é construída de maneira desproporcional no Canto Primeiro de O poema do frade. A descrição da visão de mundo e das opiniões pessoais de Jônatas é priorizada; por outro lado, traços determinantes no caráter do herói épico - como a beleza física e a linhagem social ${ }^{62}$ —, são deliberadamente omitidos. Apresentam-se primeiro seus traços psicológicos para somente, muitas estrofes adiante, designá-lo pelo nome próprio. Mais uma vez, se verifica a tendência ao adiamento do suposto assunto principal no poema, bem como a preferência pela exposição difusa, e a priorização de elementos mais abstratos em detrimento de outros mais objetivos e concretos.

Outros elementos relacionados ao exórdio, como a proposição, invocação e a dedicatória são igualmente subvertidos por Álvares de Azevedo. O prólogo de O poema do frade não apresenta também a invocação à musa e a dedicatória a uma autoridade política, elementos tradicionalmente inseridos na proposição de epopeias. O eu poético do poema de Álvares de Azevedo não pede auxílio à musa para que ela o inspire e assim

\footnotetext{
${ }^{61}$ AZEVEDO, Álvares de. “O poema do frade”. In: Álvares de Azevedo: Poesias completas, p. 315.

${ }^{62}$ CURTIUS, Ernst Robert. Capítulo IX "Heróis e Soberanos”, in: Literatura Europeia e Idade Média Latina. São Paulo: Hucitec/Edusp, 1996, p. 223. A subversão do modelo do heroi de epopeia em $O$ Poema do Frade é assunto do próximo capítulo desta dissertação.
} 
possa concluir bem o seu canto. Robert Ernst Curtius explica que o imaginário das Musas está vinculado a uma experiência poética pautada na oralidade; a concepção de "canto" poético se vincula a ideia do "cantar e dizer". A existência poética das musas se ancora também numa crença religiosa fundamental, que justifique a intervenção divina invocada pelo poeta épico. Segundo Curtius, tanto a experiência oral como o mito entram em crise na Modernidade. A consciência dos atos de escrever e ler silenciosamente a poesia aponta um processo de isolamento do poeta e de fragmentação social, que sinalizam o colapso da vivência comunitária inerente ao épico antigo. A noção de literatura como experiência silenciosa e particular passa a ser estruturante na composição do texto moderno ${ }^{63}$, traço este perceptível no emprego disseminado de metalinguagem (teoria). ${ }^{64}$ Vale lembrar que muitos dos devaneios e digressões presentes ao longo de $O$ poema do frade são pretextos para reflexões metapoéticas.

A desaparição das Musas na Modernidade é comentada por Curtius nos seguintes termos:

\footnotetext{
Nada mais frio e absurdo do que a invocação das Musas por um moderno. Em último caso, é preferível invocar - como fez Samuel Buttler em seu Hudibras (1663) - um copo de cerveja, que talvez tenha inspirado mais poesia e prosa do que todas as águas do Hipocrente e do Hélicon. ${ }^{65}$
}

A substituição da musa antiga pela prosaica garrafa de bebida como fonte de inspiração poética é sugerida pela epígrafe que abre o Canto Primeiro de $O$ poema do frade. Trata-se de um trecho citado de Don Juan, de Lord Byron: "Man being reasonable must get drunk/ The best of life is intoxication..." ${ }^{66}$ Ao longo de todo o poema alvaresiano em estudo, as garrafas e taças transbordantes são amplamente requisitadas pelo narrador-frade e pela personagem Jônatas, ambos poetas libertinos. No fechamento do Canto Segundo, o primeiro deles suspende a narração por alegar o esvaziamento de seu copo. A personagem Jônatas compõe somente bêbada, conforme é possível observar na estância abaixo:

Só quando o fogo do licor corria Da fronte no palor que avermelhava, Com as convulsas mãos a taça enchia. Então a inspiração lhe afervorava

\footnotetext{
${ }^{63}$ Idem, Capítulo XIII “As Musas”, p.405.

${ }^{64}$ Este assunto será discutido mais especificamente no quarto capítulo.

${ }^{65}$ CURTIUS, idem, p.310.

${ }^{66}$ AZEVEDO, Álvares de, 2002, p.307.
} 
E do vinho no eflúvio e nos ressábios

Vinha o fogo de gênio à flor dos lábios! $!^{67}$

Outro topos de epopeia mencionado mais acima, também não contemplado no prólogo de $O$ poema do frade, é o emprego da dedicatória a uma autoridade, a quem o poeta oferece submissão. Na tradição clássica, a dedicatória é destinada à autoridades políticas e religiosas, tais como reis, papas, ou até mesmo Deus. ${ }^{68}$ A escolha de uma autoridade a quem se possa dedicar o poema épico se vincula à função essencial da arte clássica: louvar as virtudes e as ações nobres. Nesse sentido, o louvor à figura homenageada pretende ser análogo à elevação da matéria narrada. Ainda segundo Curtius, o poeta épico muitas vezes emprega os topoi do indizível, por meio dos quais simula a própria inferioridade ao alegar não encontrar palavras suficientes para elogiar o alto soberano, a quem se dirige e espera a proteção do mecenato. ${ }^{69}$

De certa maneira, a dedicatória convencional é substituída pela inserção da epígrafe geral, que abre $O$ poema do frade, no caso, um excerto célebre da comédia Don Juan, de Molière, na qual o aristocrata libertino, que dá nome à obra, afirma o seu ceticismo, quando perguntado se acredita em algo: Je crois que deux et deux sont quatre,/ Sganarelle, et que quatre et quatre sont huit. ${ }^{70}$ Nesse sentido, o narrador, a personagem Jônatas e a própria poética de Álvares de Azevedo sugerem a filiação a essa tradição libertina, sugerida pela epígrafe geral de Molière, seguida por outra do Don Juan de Byron, no Canto Primeiro. Mais do que uma tradição libertina, ressalta-se a escolha de vinculação a uma tradição de poetas, e não de autoridades situadas para além do campo da arte. Este aspecto remete a uma postura romântica mais ampla, que afirma o valor da arte em si, sem a sua instrumentalização a serviço da moral, da religião, ou como entretenimento dedicado a oferecer repouso no intervalo da rotina de trabalho, conforme era concebida pelo neoclassicismo e depois pela burguesia. ${ }^{71}$

${ }^{67}$ Canto Primeiro, estr. XXVI, p.313. A embriaguez como condição fundamental do poetar surge no comentário debochado da personagem Puff, do poema "Boêmios", também de autoria de Álvares de Azevedo: "Toma dez bebedeiras - são dez cantos./ Quanto a mim tenho fé que a poesia/ Dorme dentro do vinho. Os bons poetas/ Para ser imortais beberam muito", in: AZEVEDO, Álvares de, 2000, p. 211.

${ }^{68}$ CURTIUS, 1996, p.130.

${ }^{69}$ Idem, p. 213.

${ }^{70}$ AZEVEDO, Álvares de, 2002, p.305.

${ }^{71}$ Segundo M. H. Abrams, para Aristóteles a poesia é resultado do instinto de imitação do homem, e se constitui em uma via bastante útil de instrução cívica e moral do público, por tornar a matéria tratada mais agradável e memorizável. Nas teorias de Aristóteles, Horácio, Cícero e dos Pais da Igreja, a arte é concebida pragmaticamente: seu fim é gerar um efeito moral sobre o auditório, conjugando deleite e utilidade. Subordinada a uma ordem racional maior, ela é elaborada em conformidade com normas objetivas, inspiradas na harmonia de leis universais e eternas. Cf. ABRAMS, M. H. El espejo y lámpara: Tradición critica acerca del hecho literário, Buenos Aires: Editorial Nova, 1962, p.32. 
A ausência de dedicatória oferecida a uma autoridade em $O$ poema do frade se explica pelo contexto posterior a queda do Antigo Regime, no qual o mecenato patrocinado pela nobreza e pela Igreja é substituído pelo processo de profissionalização do poeta no sistema capitalista, então vigente. Na realidade competitiva e individualista, que reduz a arte a mais um produto a ser trocado no mercado, o miserável e rebelde poeta Jônatas se mostra hostil não apenas às antigas elites, mas estende seu desprezo aos líderes contemporâneos, e até mesmo ao povo, diante dos quais não manifesta nenhum entusiasmo ou simpatia: "Embuçada no orgulho a fronte erguia/ E do povo e dos reis escarnecia!" (Canto Primeiro, estrofe XXVII). Tal postura é incompatível com as expectativas de um herói épico, líder e guia das aspirações coletivas. Em um tempo no qual a poesia é relegada à marginalidade, e a violência e o conflito permanentes são esvaziados de significado divino, resta a Jônatas admirar as "tradições guerreiras" vivas somente em sua imaginação, e para sempre perdidas nas "épicas sombras do passado". Os feitos bélicos deixam de figurar como ocasiões extraordinárias, fora da ordem cotidiana. Seu prosaísmo e banalização se tornam incompatíveis com a fantasia poética.

O frade-narrador do poema alvaresiano em questão também se descreve no Canto Terceiro como um sujeito isolado no convento, divorciado da sociedade, da qual espera "viver bem longe". A caracterização do narrador como frade é também irônica, tendo-se em vista que a palavra "frade" remete a frater, "irmão", ou a alguém que abre mão de sua individualidade para devotar a vida à ação coletiva e missionária. ${ }^{72} \mathrm{O}$ narrador comporta-se mais ao modo do monge romântico, dedicado ao retiro espiritual para melhor fruir a arte e a beleza — elevada a uma espécie de religião estética ideal, capaz de reunificar o espiritual e o sensível, e de recuperar a aura da obra de arte, perdida com a secularização da vida após a Revolução Francesa e a falência da estrutura do mecenato, que integrava o artista a uma unidade divina e política. ${ }^{73}$

O frade criado por Álvares de Azevedo caracteriza a sua juventude como libertina, inclinada ao prazer sexual, à bebida e aos banquetes, aproximando a sua conduta juvenil daquela de Jônatas —, personagem nada cívica ou virtuosa, de quem se mostra simpático às ideias, manifestando inclusive a mesma tendência à subversão e à obscuridade que a caracteriza. Todas as suas ilusões foram perdidas em meio ao "mundo prostituto", do qual conservou apenas a companhia da fumaça, a um só tempo

\footnotetext{
${ }^{72}$ Esta questão é aprofundada no capítulo terceiro desta dissertação.

${ }^{73}$ SAFRANSKI, Rüdiger. "Capítulo X", in: Romantismo: uma questão alemã. Tradução de Rita Rios. São Paulo: Estação Liberdade, 2010, pp. 177-190.
} 
etérea e sensual, produzida pelo charuto, tratado por ele como um amigo. ${ }^{74}$ Diante dessa posição individualista manifestada em relação ao tempo presente e à sociedade em $O$ poema do frade, se tornaria incompatível a presença de uma dedicatória consagrada a uma autoridade nos moldes da epopeia. ${ }^{75}$

Nessa ordem de questões, é interessante pensar também no tratamento que Álvares de Azevedo deu ao tema da dedicatória no poema "Ideias Íntimas". Conforme bem aponta Alcides Villaça: “[Álvares de Azevedo] presta homenagem aos 'seus' poetas (Dante, Shakespeare, Byron), diante dos quais, ironicamente, promete compor um grande poema heroico, dedicado... ao velho candeeiro que sobre a mesa 'se espreguiça" ${ }^{76}$ A postura conflituosa e irreverente para com a sociedade, com o tempo presente e com a tradição artística, expressa no prólogo de $O$ poema do frade, se manifesta não só em relação às autoridades políticas e religiosas, mas também no trato difícil com o leitor —, mais um recurso mobilizado para a instauração da teoria crítica no interior da obra de arte. A atitude de não obediência ao rígido código de regras poéticas deixa patente o desejo do frade-poeta de desrespeitar as normas de domínio coletivo, bem como frustrar as expectativas do leitor, a quem desafia com passagens confusas e desordenadas, que beiram a ilegibilidade. Este não pode confiar no narrador irônico e em a sua promessa de compor uma epopeia, anunciada no fechamento do Canto Primeiro - , promessa esta já negada de antemão, em trechos anteriores do mesmo canto, no qual se afirma a impossibilidade do herói épico no presente, enterrado para sempre nas "épicas sombras do passado" (estrofe XXVIII). Jônatas recusa-se a lutar nas guerras contemporâneas, nas quais não acredita, pois são, segundo ele, motivadas por "vis disputas" de uma realidade em que "Tudo sentiu venal!",77

Como já se discutiu neste capítulo, o encadeamento aparentemente aleatório de reflexões, devaneios e outros comentários do enunciador de $O$ poema do frade dificultam a entrada do leitor no texto, uma vez que à primeira vista não é possível definir seu assunto, finalidade ou gênero. A longa exposição dos estados da alma acaba por deslocar forçosamente a atenção do leitor para a figura do frade-poeta, e não para suas personagens ou mesmo na narração de acontecimentos objetivos, como prevê o

${ }^{74}$ AZEVEDO, Álvares de, 2002, Canto Terceiro, estr. VII e VIII, p. 326.

${ }^{75}$ No romantismo, torna-se recorrente empregar dedicatórias a mães e amigos pessoais, por exemplo. Nesses casos, observa-se uma subjetivação desse topos, uma vez que as figuras citadas pertencem à esfera privada, individualizada, do poeta. Cf. a abertura da Primeira Parte de Lira dos vinte anos e o prólogo de Iracema, por exemplo.

${ }^{76}$ VILLAÇA, Alcides. "Na intimidade romântica", in: AZEVEDO, Álvares de. Lira dos vinte anos. São Paulo: FTD, 1994, p.20.

${ }^{77}$ AZEVEDO, Álvares de, 2002, cf. estrofes XXVII a XXX do Canto Primeiro. 
enredo da epopeia antiga. Tal como as suas digressões, o narrador se desloca de uma posição marginal para se revelar o centro do poema.

Essa tendência a desorientar o leitor na introdução da obra destoa da função do prólogo tradicional da epopeia, que é a de conquistar a simpatia do ouvinte e ganhar a sua atenção para a obra: "Para conquistar o ouvinte, o orador deve confessar sua fraqueza e sua pouca experiência, louvar seus juízes; seu motivo será a amizade ou o dever cívico, etc." Por isso, "O melhor exórdio é aquele em que estas funções conquistar a boa vontade e chamar a atenção estão mais habilmente misturadas". ${ }^{78}$ Tendo esse conjunto de recomendações em mente, pode-se notar o esforço deliberado do narrador de O poema do frade em desagradar, incomodar e desnortear o público por meio de assuntos tratados de forma vaga e descontínua. Tampouco há demonstração de modéstia por parte dele na passagem abaixo:

\section{$\mathrm{XV}$}

Mas não pedirei perdão contudo: Se não gostais dessa canção sombria Não penseis que me enterre em longo estudo Para vossa alma fartar de outra harmonia! Se vario nos versos e ideias mudo É que assim me desliza a fantasia.... Mas a crítica, não... eu rio dela... Prefiro a inspiração de noite bela!

XVI

A crítica é uma velha desgraçada Que nada cria, nem jamais criara; Tem entranhas de areia regelada: É a esposa de Abrão, a pobre Sara Que nunca foi por anjo fecundada: Qual a mãe que por ele assassinara Por sua inveja e vil desesperança Dos mais santos amores a criança! $!^{79}$

A noção de "crítica" aqui repudiada é aquela concebida como um sistema de regras rígido e distinto da poesia, a que esta última deve se submeter. Tal concepção se afasta da ideia de poesia sobre a poesia, discutida mais acima neste capítulo. Neste último trecho reproduzido, o enunciador proclama de antemão o seu desprezo pela eventual aprovação da obra pelo público. De modo mais saliente, opõe-se à autoridade dos críticos que não são artistas, apontados por ele como incapazes de julgar a obra apresentada. Essa postura de rebeldia estética entra em choque direto com o decoro

${ }^{78}$ PRADO, Raquel de Almeida. Perversão da retórica, retórica da perversão: moralidade e forma literária em "As ligações perigosas" de Choderlos de Laclos. São Paulo: Editora 34, 1997, pp.36-37.

${ }^{79}$ AZEVEDO, Álvares de, 2002, pp. 310-311. 
poético e suas formulas de modéstia, obrigatórias nas introduções e conclusões das obras clássicas. ${ }^{80}$ Conforme Curtius explica: "Na introdução, o orador deve conquistar a benevolência, a atenção e a docilidade de seus ouvintes. Como consegui-lo? Em primeiro lugar, com um exórdio modesto". 81 Ao fazer uso da tópica da "falsa modéstia", o autor pode conduzir mais facilmente o leitor para o tema. ${ }^{82}$ Cícero recomendava aos autores que manifestassem a submissão e a docilidade por meio da declaração de respeito ao público e aos preceitos tradicionais. ${ }^{83}$ Para tanto, é recorrente a simulação de deficiência e de falta de preparo, bem como de temor diante dos julgamentos dos eruditos. Outra fórmula de modéstia usada é a do receio quanto ao inacabamento da obra, segundo a qual o autor alega não ter forças e engenho suficientes para cumprir a empreitada. Nesse sentido, deve destacar a sua insuficiência, a deselegância de sua linguagem, e sempre simular pedidos prévios de desculpas. É norma poética descreverse "tremendo", "angustiado", "temeroso". Ainda segundo Curtius, vem da tradição clássica romana a fórmula de glorificação cortesã da pessoa imperial. "Essa exaltação do imperador deveria corresponder ao rebaixamento da própria pessoa". ${ }^{84}$ Nesse sentido, o poeta deve omitir seu desejo de glória e manifestar o seu anseio de servir e ser útil: "a fórmula de modéstia está ligada à afirmação de que o autor só ousa escrever em obediência ao pedido, desejo ou ordem de um amigo, de um patrono ou de pessoa altamente colocada". ${ }^{85}$ Em resumo, a sua vontade ou interesse pessoal permanecem camuflados.

As oitavas de $O$ poema do frade transcritas um pouco acima caminham na contramão das recomendações de "fórmulas de auto-humilhação", "de submissão e protesto de incapacidade" perante o público e os críticos. ${ }^{86}$ Não só a independência artística do enunciador do poema é ferrenhamente defendida no Canto Primeiro, mas também a da personagem Jônatas perante o público, ao recusar imprimir seus versos ou declamá-los no teatro. A poesia de Jônatas subordina-se não ao reconhecimento do auditório, mas à livre e desordenada inspiração do "fogo do licor" espontaneidade. Há um paralelo entre a desobediência ao decoro das regras poéticas por

\footnotetext{
${ }^{80}$ CURTIUS, 1996, p.122.

${ }^{81}$ Idem, p. 126.

${ }^{82}$ Idem, p. 122.

${ }^{83}$ Idem, p. 126.

${ }^{84}$ Idem, p. 127.

${ }^{85}$ Idem, p. 128.

${ }^{86}$ As expressões em aspas são de CURTIUS, p.127.

${ }^{87}$ Cf. a estrofe XXVI do Canto Primeiro. Na mesma sequência de oitavas, critica-se a banalização da poesia a serviço dos caprichos do público, ora pautado pelas regras clássicas, ora pela moda.
} 
parte do narrador e de Jônatas, e a conduta libertina exposta por este último. Assim, pode-se pensar a apropriação dos elementos da epopeia no Canto Primeiro, citados até aqui, como exercício paródico. Na estrofe final deste canto de abertura, citada mais acima no presente capítulo, o narrador simula um pedido de desculpas pela longa extensão de seu "prólogo", ciente de que a sua construção poética não corresponde àquela prevista pela tradição retórica neoclássica, segundo a qual se recomenda a clareza e a brevidade do exórdio antigo.

O narrador simula, ironicamente, obediência às normas e à necessidade de um prólogo para realizar a introdução do leitor em seu poema, ao mesmo tempo em que as transgride. $\mathrm{O}$ trecho se vale de imagens que sugiram a ideia de simetria e adequação, associadas, no entanto, a analogias disparatadas. Segundo ele explica, o prólogo na abertura do poema seria supostamente necessário como a fachada diante de uma casa ou como um acessório de beleza na face feminina, exemplos de costumes automatizados: "Basta! foi longo o prólogo! confesso!/ Mas é preciso à casa uma fachada,/ À fronte da mulher um adereço". Particularmente interessante é o terceiro exemplo, sobre a conveniência de um lampião junto ao muro, dedicado a iluminar a "torta escada". As duas primeiras imagens antes descritas buscam inicialmente produzir o efeito de paralelismo, equilíbrio e causalidade. Porém, a imagem da escada retorcida desestabiliza esse efeito, ao introduzir a ideia de sinuosidade e fratura por meio da inserção do adjetivo "torta". Vale observar que nos dois primeiros exemplos, não existe um adjetivo que qualifique a imagem apresentada; já no último caso, a presença do vocábulo "torta" gera uma quebra de paralelismo sintático e metafórico.

A justificativa do prólogo com base no argumento do costume mecanicamente repetido insinua a prática de convenções vazias. A imagem do enfeite feminino sugere um elemento acessório, uma mercadoria, responsável por rebaixar a necessidade e o estilo elevado do prólogo de epopeia. Mesmo a imagem da fachada diante da casa parodia outra bem mais nobre, presente em textos teóricos de Gonçalves de Magalhães e José de Alencar, por exemplo. Trata-se da comparação do prólogo com a majestosa imagem do pórtico de um palácio. ${ }^{88} \mathrm{~A}$ fachada de uma mera casa citada na estrofe final do Canto primeiro de $O$ poema do frade é bem mais modesta e trivial.

\footnotetext{
${ }^{88}$ Cf. o prefácio "Lede", de Gonçalves de Magalhães, presente em Suspiros poéticos e saudades, e a "Carta Primeira" sobre A Confederação dos Tamoios, assinada por Ig, pseudônimo de José de Alencar. Ambos os textos serão comentados mais abaixo.
} 
Um último comentário acerca da imagem do lampião que ilumina a "torta escada" pode ser feito ao se pensar no papel do narrador deste poema. Ele disponibiliza a luz do lampião, ao compor um "prólogo", mas faz com que o leitor precise atravessar a escada deformada, cheia de acidentes, que é o Canto Primeiro, estruturado segundo a sua imaginação caprichosa, noite adentro. Uma habitação ordinária, um enfeite de garota e uma escada tortuosa são as imagens associadas ao prólogo de O poema do frade; elas sinalizam para o leitor a caminhada descontínua iniciada no Canto Primeiro e intensificada nos demais.

A noção de "utilidade", que pauta a tópica exordial segundo os preceitos neoclássicos, visa, antes de tudo, o benefício moral do público. Nesta lógica, uma obra justifica a sua existência no prólogo com base nos argumentos do ineditismo da matéria narrada, ou da contribuição para a "divisão [moral] do tesouro" do conhecimento, uma vez que: "a posse do saber obriga a comunicá-lo a outrem". ${ }^{89}$ Nos dois casos, busca-se ofertar ao público uma obra útil e edificante, comprometida com a instrução moral coletiva. Nesta perspectiva, a dedicação às letras se apresenta como uma ocupação virtuosa, útil até mesmo para o próprio escritor, que se livraria assim do pecado da preguiça. Dentro de uma ética produtiva de aproveitamento do tempo, "O topos da preguiça pode chegar a tal ponto que escrever poesia é aconselhado como remédio contra a ociosidade e o vício". 90

"Ociosidade" e "vício", porém, não são incompatíveis com a poesia em $O$ poema do frade - antes a favorecem. A personagem Jônatas orgulha-se de sua condição de vagabundo e devasso: "Amar, beber, dormir, eis o que amava:/ Perfumava de amor a vida inteira./ Como o cantor de Don Juan pensava/ Que é da vida o melhor a bebedeira..../ E a sua filosofia executava...". 91 Ao longo dos cantos seguintes, o enunciador do poema valoriza o repouso, a diversão e a contemplação (segundo Cilaine Alves Cunha, tópicas epicuristas ${ }^{92}$ ), e tece constantes elogios ao lazer, ao sono e aos prazeres como propícios à prática da poesia. O obscuro frade-narrador do poema alvaresiano não zela por uma postura moralista diante da poesia e da vida, mostrando-se orgulhoso de sua cumplicidade para com o libertino Jônatas e com a prostituta Consuelo, diante de quem manifesta desejo e a constrói como figura sublime.

\footnotetext{
${ }^{89}$ CURTIUS, 1996, p.131.

${ }^{90}$ Idem, p.133.

91 Cf. a estrofe XXXIII do Canto Primeiro, in: AZEVEDO, Álvares de, 2002, p. 315.

92 CUNHA, C. A. "O elogio da vagamundagem". In: SANTOS, Herbert Nunes de Almeida \& SILVA, Susana Souto. (Org.). Trilhas do humor na literatura brasileira. 1ed. Maceió: EDUFAL, 2011, v., p. 1738.
} 
Não há uma preocupação por "desperdiçar" o tempo do leitor com assuntos sem "utilidade". Assim como Jônatas, o narrador simula uma escrita guiada segundo a disposição de seu humor oscilante, sem obedecer a motivos externos e práticos. Novamente, o topos de modéstia é subvertido, uma vez que os cantos se estendem de maneira prolixa, desordenada e desigual, ao sabor da fantasia do poeta. Na tradição clássica, é comum o prólogo ser acompanhado da declaração de que o autor "deseja

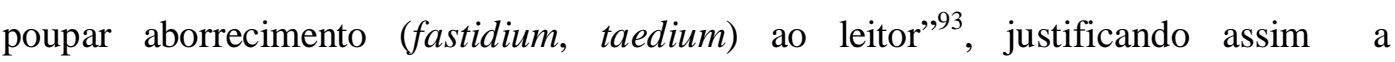
objetividade e a brevidade do exórdio.

Pensando ainda na tópica do exórdio, talvez seja interessante explorar um pouco mais a já citada oitava XXXV, que encerra do Canto Primeiro de $O$ poema do frade. Destaca-se ali uma grande carga de pathos por parte do narrador, que se despede do canto de abertura "Com a face de lágrimas banhada,/ Qual o moço Don Juan no enjoo rola/ Chorando sobre a carta da espanhola". Essa inserção do elemento patético exacerba e valoriza a sensibilidade da presença do enunciador no prólogo. Isto por si só se mostra contrário ao tom sereno, objetivo e impessoal de um narrador de epopeia. $\mathrm{O}$ trecho citado na estrofe em questão faz referência ao desfecho inglório da primeira aventura amorosa de Don Juan, de Lord Byron. ${ }^{94}$ No ápice da cena composta pelo escritor europeu, o jovem herói espanhol, desesperado com o horizonte incerto do desterro e com a intensidade da paixão contrariada, é abalado por uma náusea violenta, provocada pelo balanço simultâneo do barco sobre as ondas marítimas. O herói sedutor de Lord Byron chega literalmente a vomitar no clímax do episódio de sofrimento, gerando uma cena tragicômica. Os sintomas físicos do rapaz contrastam com seus arroubos idealistas durante o tormento amoroso: nessa mistura entre os planos elevado e baixo, a cena do adeus definitivo à amada e à terra natal é deliberadamente arruinada pelo narrador byroniano. No mesmo ritmo balouçante, a primeira amante de Don Juan fica para trás, tão logo o moço espanhol se insere em um outro espaço, deixando-se levar por mais um episódio amoroso, que dá continuidade à sua longa e variada cadeia de aventuras sentimentais.

A referência à cena de desespero e enjoo de Don Juan em O poema do frade tematiza o arremate inglório, presente tanto na citação à primeira experiência amorosa de Don Juan, quanto no resultado final do Canto Primeiro do poema alvaresiano

\footnotetext{
${ }^{93}$ CURTIUS, 1996, p.128.

${ }^{94} \mathrm{Na}$ cena original, a personagem byroniana se despede da vida que levava até então e caminha para o exílio, enquanto lê a carta de sua amante Dona Júlia, com quem mantivera um primeiro relacionamento adúltero.
} 
enquanto exórdio. Todavia, a noção de "fracasso" romântico deve ser pensada com especial atenção, pois esta estética não encara a completude como valor ou meta possível de ser realizada. A concepção de unidade da obra de arte romântica aponta para um devir, evidenciado por sua estrutura aberta: sua representação deve pressupor a referência uma obra de arte necessariamente superior a ela mesma. ${ }^{95}$ Nas palavras de Walter Benjanim, a obra de arte é, por um lado, "forma-de-exposição" e, por outro, "Ideia da Arte". ${ }^{96}$ A unidade da obra é relativa, e "permanece um ensaio no qual o um e o todo encontram-se reunidos". ${ }^{97} \mathrm{O}$ artista romântico é consciente da distância que separa a obra realizada e aquela imaginada. Coloca-se o problema de representação de um ideal infinito e total numa forma concreta, finita, parcial. Cada obra de arte particular é um fragmento que aponta para um todo maior, que se apresenta como ideia a ser perseguida pela reflexão poética infinitamente em movimento.

\section{Prólogos indianistas: dois exemplos}

Álvares de Azevedo busca revisar a forma do prólogo de epopeia no Canto Primeiro de $O$ poema do frade, ao apropriar-se de determinados elementos cultivados nesse gênero, para então subvertê-los. Como é sabido, a experimentação poética, e a busca por novas formas e temas, são tendências românticas bastante amplas. A defesa do princípio romântico de originalidade não implica, porém, o abandono da herança clássica: o que está em jogo é uma apropriação mais flexível desta última, bem como a liberdade em promover mesclas e combinações poéticas, dando origem a novos gêneros híbridos.

No romantismo brasileiro há autores românticos comprometidos de variadas formas com a herança neoclássica. A composição de prólogos encontrados em suas obras permite vislumbrar continuidades, rupturas e apropriações da poética antiga e a forma como fazem-na conviver com as novas exigências da estética romântica. O poeta Gonçalves de Magalhães, por exemplo, famoso por sua tentativa de composição de uma epopeia nacional em A Confederação dos Tamoios, teoriza a respeito da função do prólogo no prefácio "Lede", introdução a seu conjunto de poesias líricas Suspiros

${ }^{95}$ BENJAMIN, Walter. O conceito de crítica de arte no romantismo alemão. São Paulo. Editora Iluminuras, 1999, p.83.

${ }^{96}$ Idem, p.92-93.

${ }^{97}$ Idem, p. 83 . 
Poéticos e Saudades (1836) —, considerada marco oficial do início do romantismo brasileiro:

Pede o uso que se dê um prólogo ao Livro, como um pórtico ao edifício; e como este deve indicar por sua construção a que Divindade se consagra o templo, assim deve aquele designar o caráter da obra. Santo uso de que nos aproveitemos, para desvanecer alguns preconceitos, que talvez contra este Livro se elevem em alguns espíritos apoucados. ${ }^{98}$

No trecho, o poeta se empenha em respeitar o "uso" tradicional reservado ao exórdio, comparado ao "pórtico" de um "templo" mitológico, destinado a introduzir o leitor com solenidade na obra. Magalhães se vale do prólogo para defender e justificar a sua poética, e, de modo bastante didático, propõe a discussão de "três cousas" fundamentais para a avaliação da obra apresentada: "o fim, o gênero, e a forma". A finalidade de sua poesia, ele afirma, é a elevação "à sublime fonte donde ela emana", isto é, da fé cristã: “A Poesia, este aroma d'alma, deve de contínuo subir ao Senhor; som acorde da inteligência deve santificar as virtudes, e amaldiçoar os vícios. O poeta, empunhando a lira da Razão, cumpre-lhe vibrar as cordas eternas do Santo, do Justo e do Belo".

Quanto a definição do gênero de sua obra no prefácio, é interessante notar que Gonçalves de Magalhães defende o alinhamento à nova estética, e ataca as convenções da tradição neoclássica como exemplos de artificialidade e fingimento. Ele também privilegia o cristianismo em detrimento da mitologia, "Antigos e safados ornamentos, de que todos se servem”. Por fim, o autor de Suspiros Poéticos e Saudades enaltece a livre inspiração, que gera a heterogeneidade de formas e motivos:

Quanto à forma, isto é, a construção, por assim dizer, material das estrofes, e de cada cântico em particular, nenhuma ordem seguimos; exprimindo as ideias como elas se apresentaram, para não destruir o acento da inspiração; além de que, a igualdade dos versos, a regularidade das rimas, e a simetria das estâncias produz uma tal monotonia, e dá certa feição de concertado artifício que jamais podem agradar. Ora, não se compõe uma orquestra só com sons doces e flautados; cada paixão requer sua linguagem própria, seus sons imitativos, e períodos explicativos. ${ }^{99}$

Magalhães se vale das convenções românticas que simulam espontaneidade expressiva. Na abertura de seu prólogo, destaca a importância do desenvolvimento de

\footnotetext{
${ }^{98}$ MAGALHÃES, Gonçalves de. "Lede", in: Caminhos do pensamento crítico, organização de Afrânio Coutinho._Rio de Janeiro: Pallas/ Instituto Nacional do Livro/ Ministério da Educação e da Cultura, 1980, vol. I, p.39.

${ }^{99}$ Idem, p.40.
} 
livres impressões e reflexões, como motor criativo, não subordinadas a um tema único. A figura de um eu caminhante e meditativo, que se desloca por diferentes cenários e países, se faz presente. Em Gonçalves de Magalhães, porém, o desejo de espontaneidade poética convive com a ânsia pela ordem, harmonia, moderação, linearidade:

São poesias de um peregrino, variadas como as cenas da Natureza, diversas como as fases da vida, mas que se harmonizam pela unidade do pensamento, e se ligam como os anéis de uma cadeia; poesias d'alma, e do coração, e que só pela alma e o coração devem ser julgadas. ${ }^{100}$

Acima, Magalhães defende uma literatura atrelada à moral religiosa e à utilidade coletiva. Seus olhos como artista estão voltados para as leis da Natureza; nesta perspectiva, a exteriorização da perfeição divina. Esta postura favorece a exaltação da paisagem brasileira e da fé cristã, temas basilares da estética indianista em seu programa nacionalista.

O grupo dos "primeiros românticos" brasileiros é denominado de "geração vacilante" por Antonio Candido. Na produção desses indianistas, fortes traços da herança neoclássica convivem com a aspiração por novas formas capazes de expressar a originalidade do caráter nacional brasileiro. Por outro lado, o desejo de consolidar uma tradição e delimitar o seu lugar como nação civilizada na cultura ocidental, estimulou nesses artistas o projeto de composição de uma epopeia nacional - empreitada patrocinada por Dom Pedro II, como é o caso de A Confederação dos Tamoios (1857), de Gonçalves de Magalhães. A obra em questão foi dedicada ao monarca, conforme o uso consagrado na tradição neoclássica. Segundo Antonio Candido, essa prática de oferecimento de dedicatórias ao jovem Dom Pedro II era recorrente dentre os românticos brasileiros ligados aos quadros oficiais do governo. ${ }^{101}$ A coexistência entre as tendências nova e antiga na produção desses autores foi definida pelo crítico da seguinte maneira:

$\mathrm{Na}$ literatura, o decênio de 1850 viu a consagração do romantismo, cuja manifestação considerada mais nacional, o indianismo, teve nele o momento de maior prestígio e, extravasando da lírica, chegou ao mesmo tempo ao romance e à epopeia, numa curiosa coexistência de arcaísmo e modernidade. $^{102}$

\footnotetext{
${ }^{100}$ Idem, p.39.

101 CANDIDO, Antonio. "Geração Vacilante", in: Formação da literatura brasileira: momentos decisivos. 7. ed., Belo Horizonte: Itatiaia, 1993, pp. 41-42.

${ }^{102}$ Idem, $O$ romantismo no Brasil. São Paulo: Humanitas, FFLCH, 2004, p.44.
} 
Cilaine Alves Cunha comenta a relação de Gonçalves de Magalhães com os modelos neoclássicos. Para a estudiosa, a construção do prólogo "Lede" se pauta pela simplicidade formal e obedece a uma exposição linear, na qual "a abertura expõe as intenções gerais, o desenvolvimento justifica os argumentos e a conclusão afeta modéstia a fim de garantir a simpatia do leitor". ${ }^{103}$ Numa passagem do mesmo prefácio, Magalhães refere-se a seu livro como "uma tentativa", "um ensaio". As palavras de Magalhães sugerem o seu alinhamento às fórmulas de modéstia tradicionais, segundo as quais o poeta rebaixa a sua obra e minimiza as suas intenções, com vistas a parecer simpático a seus leitores brasileiros —, familiarizados com o repertório neoclássico e com um romantismo mais moderado, avesso a radicalizações e extremismos poéticos. ${ }^{104}$ A tópica do inacabamento da obra poética em Gonçalves de Magalhães não se traduz na experimentação formal característica de certo romantismo, que encara a obra de arte como uma realização necessariamente parcial e provisória, e que se comunica com um ideal artístico sempre maior e irrepresentável em sua totalidade. ${ }^{105}$

Há outros elementos presentes no prefácio "Lede" que demonstram a oscilação de Magalhães entre o neoclassicismo e o romantismo. O autor define sua poesia como manifestação espontânea, mas também como tributo pago à Pátria: ele se refere à literatura como atividade cultivada quando "a atenção descansa, fatigada pela seriedade da ciência". ${ }^{106}$ A visão utilitária e cívica insere a poesia como prática subordinada ao mundo do trabalho e da ciência, e destoa, por exemplo, da tendência de Álvares de Azevedo e de outras vertentes românticas, nas quais a poesia é encarada como instância autônoma, e mais alta via da formação humana. ${ }^{107}$ Nesse sentido, a escolha de um

${ }^{103}$ CUNHA, Cilaine Alves. Entusiasmo indianista e ironia byroniana. Tese de doutorado/ FFLCH/USP. São Paulo, 2000, p.53.

${ }^{104}$ Cf. CANDIDO, 1993, p. 42.

105 Segundo Paolo D'Angelo, a arte romântica pode ser definida como tentativa de exposição ou representação do infinito de modo finito; cf. D’ANGELO, Paolo. "Gnosiologia superior", in: A estética do romantismo. Lisboa: Estampa, 1998, pp. 75-80. Esta consciência da cisão entre o Espírito e a letra também é definida por Walter Benjamin na relação entre "Ideia da Arte" e "forma-de-exposição". Cf. BENJAMIN, Walter. O conceito de crítica de arte no romantismo alemão. São Paulo: Editora Iluminuras, 1999, pp. 92-93.

106 MAGALHÃES, Gonçalves de, 1980, p.41.

107 O romantismo valorizou o conceito de "formação" (Bildung) como expressão de um processo permanente que contempla o homem de maneira integral: seus afetos, as facetas obscuras da mente, não abarcados pela razão iluminista também devem ser investigados, sem reprimi-los como manifestações menores ou inferiores do humano. Neste sentido, a educação estética se torna uma via privilegiada para a busca do homem integral, sonho perseguido pelo homem moderno, cindido pelas contradições de uma realidade parcial, guiada unicamente pela valorização do útil, do moral e do racional da moral burguesa. Márcio Suzuki o define o conceito de Bildung da seguinte maneira: "Formação completa das faculdades do espírito, essa unificação real do homem e do filósofo no artista pode ser pensada como um 
libertino vadio e rebelde como herói em $O$ poema do frade não é fortuita, pois se contrapõe abertamente à concepção de literatura subordinada a outras esferas da sociedade tidas como mais legítimas pela moral burguesa.

Em linhas gerais, os prólogos clássico e romântico se distinguem nos seguintes aspectos:

Se a um classicista o prólogo (pórtico) se torna o emblema unificador de matérias, para um romântico, de maneira completamente diferente, ele é um dos muitos recursos (...) de estruturação da reflexão irônica, concebida pelo embate entre diferentes ideias, o que, no limite, favorece a dispersão das mesmas. Na definição de Magalhães, no entanto, o prólogo não se constitui como uma instância privilegiada da irônica reflexão relativizadora de ideias, mas como um emblema que as unifica. ${ }^{108}$

No caso do Canto Primeiro, prólogo de $O$ poema do frade, a recorrente prolixidade e o livre deslocamento dos devaneios, engendrados por seu enunciador, favorecem a experimentação formal e ação da ironia, e contribuem para a dissolução da forma do prólogo tradicional, ao fundir poesia e teoria em um único espaço textual:

De acordo com os pressupostos do romantismo a respeito do inacabamento formal, o prólogo é um entre inúmeros recursos que permitem a estruturação da reflexão irônica, dialeticamente concebida pelo embate entre diferentes ideias que, no limite, permite sua dispersão. ${ }^{109}$

José de Alencar também teorizou sobre o prólogo romântico em alguns de seus escritos. Na primeira carta da série de críticas à epopeia A Confederação dos Tamoios, Alencar afirma que o tratamento e a escolha do assunto, desenvolvidos por Gonçalves de Magalhães, não estão à altura das convenções exigidas pelo gênero da epopeia. Alencar fala da trivialidade e da falta de entusiasmo poético com que se abre $A$ Confederação dos Tamoios, a seu ver carente de fantasia, de pinturas vibrantes e majestosas, daquelas capazes de arrebatar a atenção do leitor para a narrativa:

desdobramento da Terceira Crítica de Kant e da educação estética de Schiller, ambas entendidas como passagem do sensível ao supra-sensível". Cf. SUZUKI, Márcio. "O filósofo e a vida", in: $O$ gênio romântico. São Paulo: Iluminuras/Fapesp, 1998, p.102. Friedrich Schlegel propõe uma nova ética e uma nova religião, capaz de transcender as dualidades da moral burguesa, e reaproximar o sensível do ideal. Sobre a ética e a espiritualidade como experiência estética, cf. SCHLEGEL, Friedrich. Lucinde. Valencia: Editorial Natán, 1987.

${ }^{108}$ CUNHA, Cilane Alves, 2000, pp.42-43.

${ }^{109}$ Idem, idem, p.149. 
Um poema épico, como eu o compreendo, e como tenho visto realizado, deve abrir-se por um quadro majestoso, por uma cena digna do elevado assunto que se vai tratar.

Não se entra em um palácio real por uma portinha travessa, mas por um pórtico grandioso, por um peristilo, onde a arte delineou algumas dessas belas imagens que infundem admiração. ${ }^{110}$

Além disso, Alencar salienta a sensação de desligamento e de acidentalidade do assunto tratado na abertura em relação à sequência do enredo. Ele reclama da ausência de grandeza divina e da elevação poética, características do herói épico tradicional, mas carentes no protagonista prosaico escolhido por Magalhães.

Já no romance Iracema (1865), José de Alencar busca acertar as contas com o indianismo do grupo de Magalhães, além de propor uma solução para o impasse da epopeia nacional no romantismo. O escritor apresenta um prefácio antes do romance citado, mas anuncia sua predileção pelo posfácio que também integra a mesma obra. Ele manifesta desprezo diante da exigência inflexível de um prólogo na abertura das produções literárias: "sempre fui avesso aos prólogos; em seu conceito eles fazem à obra o mesmo que o pássaro à fruta antes de colhida; roubam as primícias do sabor literário. Para isso me reservo depois". 111

Alencar propõe manter o suspense da narração, sem comentá-la previamente ou fornecer um quadro sucinto do que o leitor encontrará. Ao proceder assim, recusa o breve resumo panorâmico do enredo, presente nas proposições da tradição clássica. Ainda assim, o autor de Iracema se preocupa em orientar seus leitores, comunicandolhes o itinerário segundo o qual organiza a sua obra: "Na última página me encontrará de novo; então conversaremos a gosto, em mais liberdade do que teríamos neste postiço do livro, onde a etiqueta manda receber o público com a gravidade e a reverência devida a tão alto senhor". À sua maneira, Alencar consegue conciliar o respeito a algumas funções tradicionais do prólogo, ao mesmo tempo em que se vale dele de uma maneira mais pessoal.

O prefácio e o posfácio de Iracema são dedicados ao amigo Jaguaribe ${ }^{112}$, a quem o romancista se refere na citação acima como o "tão alto senhor". Jaguaribe ocupa o papel de interlocutor particular do narrador, mas representa também o auditório em

\footnotetext{
${ }^{110}$ ALENCAR, José de. "Carta Primeira”, in: Caminhos do pensamento crítico, organização de Afrânio Coutinho. Rio de Janeiro: Pallas/ Instituto Nacional do Livro/ Ministério da Educação e da Cultura, 1980, vol. I, p.82.

${ }^{111}$ Idem, p. 115.

112 Vale observar que a dedicatória é endereçada a um amigo, cúmplice e confidente do romancista, e não a uma autoridade a quem o poeta está subordinado, como é o caso clássico. Essa relação de igualdade ali tematizada está de acordo com os valores do individualismo preconizados pela burguesia.
} 
geral, diante do qual o Alencar se posiciona. Predomina no prólogo de Iracema o tom informal, que se reflete tanto no discurso como na escolha das formas adotadas: a recorrência a memórias pessoais de sua terra natal, e a evocação de um ambiente familiar e privado, repleto de sentimentalismo, reforçam esse efeito de subjetivação do prólogo alencariano. O tom de informalidade e de conversa entre amigos é mantido no pósfácio, texto no qual o autor de Iracema desenvolve uma reflexão mais longa sobre o gênero romance, e outras questões estéticas pertinentes ao contexto romântico brasileiro. Se no prefácio ao livro Suspiros poéticos e saudades Gonçalves de Magalhães sugere a entrada no pórtico de um edifício rígido e solene, Alencar, por outro lado, apresenta a imagem de uma rede de balanço delicado, e propõe ao leitor uma prosa acolhedora, íntima, tal como aquela trocada com o amigo Jaguaribe. ${ }^{113}$

\section{Alguns prólogos de Álvares de Azevedo}

No estudo Entusiasmo Indianista e Ironia Byroniana, Cilaine Alves Cunha mostra que o cultivo de estruturas de discurso não lineares é uma prática recorrente na poética alvaresiana. A estudiosa analisa o poema "O Editor", presente na segunda parte de Lira dos vinte anos, e salienta o embaralhamento da estrutura, deliberadamente desordenada, do poema e o efeito gerado por sua estrofe inicial, abrupta demais para funcionar como introdução: “Álvares de Azevedo estruturou o poema de modo a jogar a introdução para o meio, a conclusão para o início, o meio para o fim. Prática essa corriqueira na obra desse autor que, no poema 'Boêmios', por exemplo, joga o prólogo para o final". 114

Como a autora afirma, o exercício da "falsa introdução" na escrita de Álvares de Azevedo se faz presente no poema "Boêmios", outro texto que integra a segunda parte de Lira dos vinte anos. Ainda segundo Cunha, o poema em questão é iniciado com o diálogo dos "letrados indigentes" Níni e Puff, motivado pelo desejo deste último de compor uma obra prima capaz de alcançar o panteão da glória. Níni deseja que o amigo escute e comente a sua narrativa, porém este não o faz de bom grado, interrompendo o

\footnotetext{
${ }^{113}$ A eleição do colóquio como gênero de discussão estética é recorrente no romantismo. É o caso dos textos encontrados em Conversa sobre a Poesia, de Friedrich Schlegel. Numa mistura entre ficção e teoria, o autor dramatiza questões estéticas na boca de personagens, dotados de diferentes pontos de vista. Vale ressaltar que o diálogo é a forma por excelência da ironia e da sátira menipeia. Ela instaura a polêmica, como nos diálogos platônicos centrados na figura de Sócrates.

${ }^{114}$ CUNHA, Cilaine Alves, 2000, p.267.
} 
discurso de Níni a todo momento com fofocas sobre padres, nobres, bebidas, banquetes e mulheres bonitas. O tratamento que Puff dispensa aos temas citados contrasta com o tom moralista do projeto de tragédia neoclássica de Níni.

A certa altura, Níni consegue se impor e contar todo o enredo planejado para Puff —, não sem primeiro obedecer à condição estabelecida por seu ouvinte, que exige uma garrafa de vinho como presente em troca de sua atenção. Ainda assim, ao final da narração, Níni percebe o amigo dormindo, alheio à história contada. As personagens e o enredo movido por peripécias ${ }^{115}$, típico de uma tragédia clássica, desencadeiam "tédio e sono""116 em Puff. O poema "Boêmios" não se encerra aí. Um homem surge bruscamente e interrompe a cena, protestando contra a peça maçante apresentada, desinteressante até mesmo para o ponto, funcionário do teatro encarregado de ler a fala dos atores no roteiro e lhes auxiliar a memória. Assim como Puff, o ponto "dorme a sono solto!". Tão logo a reclamação é feita, um pano se levanta, evidenciando com isso o palco de um teatro. Surge o "Prólogo" em pessoa, para comentar o conteúdo diante do público. Caracterizado como um "velho de cabeça calva, camisola branca, carapuça coroada de louros", porta "um ramo de oliveira na mão", e faz "as cortesias do estilo", ele pede ao auditório que releve o amadorismo do autor e a irregularidade do gênero do texto apresentado. ${ }^{117}$

Segundo Cilaine Alves Cunha aponta, não fica claro para qual alvo o Prólogo dirige seus comentários, e nem qual é o objeto de reclamação do "Homem da Plateia"; se as considerações de ambos são direcionadas para a narrativa de Níni, ou se estendem também para a avaliação do poema "Boêmios" como um todo, que integra o projeto da tragédia de Níni (ao mesmo tempo autor e personagem) e os comentários de bastidor posteriores em um único conjunto heterogêneo. A autora sinaliza esta última hipótese, que prioriza a problematização da estranha inserção do Prólogo apenas no final do poema.

\footnotetext{
115 Algumas vertentes do romantismo estão mais comprometidas com um enredo mais linear pautado nas ações objetivas de personagens. Como Cilaine Alves Cunha mostra, por exemplo, a literatura indianista no Brasil oscilava entre a reverência às formas consagradas pela tradição e as inovações estéticas propostas pelo romantismo. Cf. CUNHA, Cilaine Alves . Entusiasmo indianista e ironia byroniana, Tese de doutorado. FFLCH/USP. São Paulo, 2000.

${ }^{116}$ Idem, p.338. Níni reconhece que as suas ideias são previsíveis e monótonas, mas adere a elas ao afirmar que estas asseguram a moralidade do poema, aspecto do qual o autor neoclássico não cogita abrir mão: "A historia infelizmente é muito vista/ Não sou original! É uma desgraça!/ Mas prefiro o caráter verdadeiro/ De trovador cronista". (estr. IX). Níni se mostra esteticamente conservador ao justificar a manutenção das convenções vigentes, em nome de uma verdade pretensamente unívoca.

${ }^{117}$ Idem, idem.
} 
Esse deslocamento do Prólogo gera uma ambiguidade estratégica, pois a quebra da linearidade discursiva convencional composta de prólogo-desenvolvimentoconclusão acaba por desestabilizar o aparente foco inicial do poema, centrado em Puff e Níni. A presença do Prólogo rompe com a ilusão dramática, além de incorporar em sua fala uma discussão metapoética, a respeito do gênero irregular praticado no poema "Boêmios". Esta irregularidade, ele explica, é resultado da mistura entre tragédia e comédia, estimuladas pelo gosto do autor do poema pelo estilo de Dom Quixote.

A reflexão explícita sobre a experimentação formal realizada no poema tem o “objetivo de discutir a relação entre clássico e moderno" no interior da própria obra de arte, bem como contestar o gosto do público, "acostumado com convenções rígidas e previsíveis". ${ }^{118} \mathrm{O}$ acoplamento de uma peça dentro de uma peça - que ao final se revela um poema metapoético — desnorteia o leitor, que não pode contar com um modelo prévio e bem delimitado pela tradição para se orientar. Níni segue um discurso linear, com proposição, narração e epílogo; por outro lado, o estilo do narrador de "Os Boêmios" se mostra mais simpático ao de Puff, intrusivo e digressivo. O mesmo Puff assume a autoria do prefácio do "drama” Macário em outro escrito de Álvares de Azevedo. Ali, teoriza sobre sua inclinação às misturas violentas, indefinidas, e às formas irregulares, semelhantes às manchas de sangue:

Se eu imaginasse o Otelo, seria com todo o seu esgar, seu desvario selvagem, com aquela forma irregular que revela a paixão do sangue. É que as nódoas de sangue quando caem no chão não têm forma geométrica. As agonias da paixão, do desespero e do ciúme ardente quando coam num sangue tropical não se derretem em alexandrino, não se modulam nas falas banais dessa poesia de convenção que se chama — conveniências dramáticas . — ${ }^{119}$

As obras mescladas, heterogêneas, geram dificuldades de classificação quanto ao gênero literário praticado. A questão é abertamente levantada nos trechos finais do prefácio "Puff":

Quanto ao nome, chamem-no drama, comédia, dialogismo: — não importa. Não o fiz para o teatro: é um filho pálido dessas fantasias que se apoderam do crânio e inspiram a Tempestade a Shakespeare, Beppo e o IX Canto de Don Juan a Byron: que fez escrever a Annunzziata, e o Canto de Antônia a quem é Hoffmann, ou Fantasio ao poeta de Namouna. ${ }^{120}$

\footnotetext{
${ }^{118}$ Idem, idem.

119 AZEVEDO, Álvares de. "Puff", in: Macário; Noite na taverna. São Paulo: Editora Globo, 2007, p.19.

${ }^{120}$ Idem, p. 20.
} 
As implicações do "gênero problemático" cultivado em Macário foram objeto de estudo de Andrea Werkema. A autora mostra como certa linha romântica prioriza a experimentação radical e a revisão das formas tradicionais, rompendo com o modelo mimético, a ponto de tangenciar o puro abstrato que norteou o idealismo romântico. Surge o paradoxo do drama não encenável —, signo da impossível realização completa da obra de arte. ${ }^{121}$

Para Cilaine Alves Cunha, o prólogo de Macário, em especial, é uma “instância privilegiada da reflexão irônica", e o restante da obra, misto de drama e ensaio poético, se aprofunda no recurso do dialogismo, explorado por meio do debate entre personagens dotadas de pontos de vista opostos. Esses elementos problematizam os princípios miméticos, tradicionalmente basilares do gênero dramático. ${ }^{122}$ Cunha cita o exemplo do "prólogo-peça" do pré-romântico alemão Heinrich von Kleist, retirado da peça denominada justamente Um Prólogo. A existência de uma personagem que fala de si e se mostra autoconsciente de sua situação ficcional gera a destruição da ilusão artística, representando fragmentariamente "a realidade na forma de uma instância provisória". Outros autores citados pela estudiosa nesse sentido são Jean Paul Richter - que estilhaçou "a estrutura fechada e unitária da narrativa" em "romances-prefácios" — , e E. T. A. Hoffmann, escritor profundamente identificado com o fantástico, por meio do qual desestabilizou a concepção de realidade como totalidade ao sobrepor duas realidades em oposição na obra de arte e explorar o tema do duplo, evocando personagens atormentados por uma consciência cindida. ${ }^{123}$

Paolo D’Angelo também comenta obras dedicadas a destruir a ilusão de realidade artística, especialmente explorada no teatro romântico, consciente dos fortes laços que vinculam o gênero dramático à tradição mimética. Nesse sentido, D’Angelo evoca a ironia romântica, entendida como uma "parábase permanente". O caso da peça O Gato de Botas, de autoria de Ludwig Tieck, é comentado por ele. Nela, se observa a discussão de elementos extra literários, assimilados na própria composição do texto: "As conversas dos expectadores na plateia, as opiniões do autor, as trocas de palavras

\footnotetext{
121 Andrea Werkema faz uma minuciosa discussão sobre diversos aspectos presentes em Macário, inclusive sobre a relação entre a figura de Otelo e a forma irregular da obra azevadiana em questão. Cf. sobretudo o segundo capítulo de seu estudo. WERKEMA, Andréa Sirihal. Macário, ou o drama romântico em Álvares de Azevedo. Tese de doutorado, UFMG, 2007.

${ }_{122}$ CUNHA, 2000, pp.151-152.

${ }^{123}$ Idem, p. 150.
} 
entre os actores e público fazem parte da peça, tanto ou mais que os acontecimentos que deveriam ser "representados". ${ }^{124}$

Diante dessa discussão, o subtítulo do poema "Boêmios", "Ato de uma comédia não escrita", pode ser pensado a partir dessa ideia de fragmentação do eu e da realidade, inerente à obra de arte moderna. A epígrafe do poema em questão, Totus mundus agit histrionen, é o lema da companhia teatral shakespeariana (Globe) - que Azevedo indica ser um "provérbio do tempo de Shakespeare". Seu significado, "Tudo é teatro. Tudo é comédia" ${ }^{125}$, é incorporado na composição de Álvares de Azevedo como índice da construção do mundo e da realidade por meio da linguagem. Mundo e realidade podem ser apenas parcialmente assimilados pela consciência do sujeito, incapaz de ter acesso à coisa em si, percebida sempre de maneira incompleta e insuficiente pela mente do indivíduo segundo a sua perspectiva particular.

No caso do poema "Boêmios", se Álvares de Azevedo houvesse encadeado linearmente as partes do texto, e inserido o "Prólogo" em seu início, poderia evitar facilmente o estranhamento final desencadeado com a aparição inesperada do Prólogo. Sobretudo porque o trecho em questão discute abertamente uma série de questões capazes de orientar previamente a leitura do público, como o hibridismo do gênero adotado e a filiação do eu poético ao estilo de Dom Quixote. Todavia, intenção de Álvares de Azevedo não visa evitar a perplexidade, mas sim potencializá-la.

A problemática inserção do prólogo em "Boêmios" foi ainda mais agravada pela condição de obra póstuma de Álvares de Azevedo, e contribuiu inclusive para confundir alguns organizadores de sua produção poética. Na edição crítica das poesias completas de Álvares de Azevedo, preparada por Péricles Eugênio, este último não escapou à tentação de "organizar" o embaralhamento planejado por Álvares de Azevedo no poema "Boêmios":

\footnotetext{
Em todas as eds. de AA o prólogo aparece no fim, como se fosse um epílogo, mas isso contradiz o conteúdo dos versos, que são mesmo introdutórios. RMJ chama a atenção para o fato, assinalando que Veiga Miranda já o havia apontado. "A leitura atenta do original e a advertência de Veiga Miranda" escreve RMJ - "poderiam ter colocado o 'Prólogo' em seu verdadeiro lugar, nas edições feitas depois de 1931, mas todos os divulgadores da obra de Álvares de Azevedo, por preguiça de examinar os textos ou por simples automatismo, continuaram a repetir o erro da edição inicial, erro que só pode ser levado à conta do estado de confusão em que ficaram os papéis do poeta.
}

124 D'ANGELO, 1998, pp.102-103.

125 As informações sobre a epígrafe de "Boêmios" foram colhidas de uma nota de Péricles Eugênio, consultada em AZEVEDO, Álvares de, 2002, p.181. 
É possível mesmo, que o 'Prólogo' tenha sido escrito depois de todo o resto do trabalho, mas a intenção do autor nunca poderia ter sido apresentá-lo como 'Epílogo"'. Acatando esses argumentos, que são de simples bom senso, deslocamos o Prólogo para o lugar no qual sempre deveria ter estado. ${ }^{126}$

Demais obras compostas por Álvares de Azevedo propõem reflexões de ordem formal e teórica semelhantes. Algumas delas são introduzidas por prefácios, como Lira dos vinte anos, Macário e $O$ conde Lopo, nos quais as reflexões críticas expostas de antemão são fundamentais para a leitura dos textos a que precedem, ao adiantar questões que contribuem amplamente para uma compreensão mais rica da poética alvaresiana de modo geral. Dentre eles, os prefácios de Lira dos vinte anos foram elevados a manifesto poético por excelência na fortuna crítica do poeta. Já o prólogo de Macário, comentado mais acima, assume uma função menos convencional, pois se ficcionaliza ao adotar a voz de Puff, personagem do poema "Boêmios". 127

$O$ conde Lopo, por sua vez, multiplica o papel do prólogo, ao apresentar numa mesma obra uma série de aberturas. A primeira delas, denominada "Frontispício", relata a condição ficcional de obra em manuscrito, composta por um misterioso poeta louco, já falecido. A seguir, vem a "Primeira Parte", que introduz o suposto material póstumo; ela corresponde aos cantos I e II, e ainda conta com uma "Overtura”, na qual a poética de Georg Sand é comentada. O Canto I é iniciado a seguir, misturando diversas formas como a do soneto e outras menos rígidas. Por sua vez, a "Segunda Parte" de $O$ conde Lopo também conta com uma abertura, cujo subtítulo é "Invocação em todas as cordas". Por fim, os cantos III e IV apresentam uma primeira seção denominada "Prelúdios". Em resumo, $O$ Conde Lopo explora muitas formas de abertura, nas quais se multiplicam também as referências a Sand, Byron, Tasso, etc. Essa espécie de experimentação em série do tema da introdução merece uma análise, ainda a ser feita pela fortuna crítica do poeta em estudo.

Noite na taverna, O livro de Fra Gondicário e O poema do frade podem ser agrupados em um conjunto no qual não se apresenta um prefácio teórico bem delimitado em relação às obras a que antecedem, ao modo das demais composições

\footnotetext{
${ }^{126}$ Nota de Péricles Eugênio da Silva Ramos, in: AZEVEDO, 2002, pp. 181-182. Na edição da Obra completa, preparada por Alexei Bueno para a editora Aguilar, o prólogo de "Boêmios" se encontra inserido no final do poema. Cf. AZEVEDO, Álvares de. Obra completa, BUENO, Alexei (org.) Rio de Janeiro: Nova Aguilar, 2000.

${ }^{127}$ Como Andréa Werkema mostra, o prefácio em questão deve ser lido num jogo irônico com a narrativa a que precede. A (irônica) promessa de uma obra dramática ali expressa não deve conduzir toda a leitura de Macário, que faz uma passagem do drama à narrativa. Cf. WERKEMA, Andréa, 2007, p. 63 e seguintes.
} 
citadas mais acima. Noite na taverna conta com um curioso capítulo de abertura, denominado "Job Stern", que serve como uma espécie de "moldura"128, responsável por unificar em uma mesma atmosfera os contos encadeados a seguir, desenvolvidos por múltiplos narradores. Os contos seguintes são compostos de modo a desenvolver variações da tese ali exposta, acerca da prevalência do hedonismo e do ceticismo nos quais se baseia a poesia libertina. Esta espécie de "conto zero" expõe um debate fundamental para o desenvolvimento do enredo, encenado pelas diferentes personagens, que encarnam perspectivas conflitantes sobre o mundo e a poesia, dramatizadas no texto à maneira de Macário. Conforme Antonio Candido discute no ensaio "A educação pela noite", o encadeamento da cena final de Macário permite acoplar esta obra no início da narrativa de Noite na taverna, servindo-lhe como uma espécie de prólogo. ${ }^{129}$

No caso de O livro de Fra Gondicário, é possível constatar a delimitação de uma primeira parte em verso, consideravelmente longa, denominada "Lábios e sangue". O trecho apresenta um enunciador em muitos aspectos semelhante àquele de $O$ poema do frade. Tal como este, ele discute seu estilo digressivo e devaneante no interior do próprio poema. A estrutura difusa de "Lábios e sangue" dá lugar a uma segunda parte em prosa poética, na qual se desenvolve uma espécie de tragédia bastante irregular, de encadeamento narrativo truncado, e repleta de marcas de inacabamento. Há uma visível divisão entre a primeira e a segunda partes da obra, que, embora distintas entre si, parecem dialogar em conjunto. A parte inicial comenta, veladamente, alguns acontecimentos desenvolvidos na segunda parte da composição. As duas apresentam citações, epígrafes e digressões que podem indicar um fio condutor, capaz de encadear a obra, como é a hipótese de Maria Cláudia Rodrigues Alves, ao analisar as epígrafes de O livro de Fra Gondicário. ${ }^{130}$ Esta obra foi publicada pela primeira na $8^{\mathrm{a}}$ edição das obras completas de Álvares de Azevedo, organizada por Homero Pires, em 1942. Segundo o organizador, que transcreveu os manuscritos repletos de borrões, de emendas

${ }^{128}$ Cf. CUNHA, Cilaine Alves, in: “Tristeza de uma geração que termina”, in: Teresa - Revista de Literatura Brasileira, n. 6/7. São Paulo: Humanitas, 2006, p. 46.

129 CANDIDO, "A educação pela noite", in: A educação pela noite e outros ensaios. São Paulo: Ática, 1987, p.16. Embora essa hipótese seja mais conhecida por meio do ensaio citado acima, Jefferson Donizeti de Oliveira explica, em seu estudo, que esta possibilidade de continuação de Macário em Noite na taverna já havia sido sinalizada por João Pedro da Veiga Miranda, em 1931. Segundo Oliveira, Veiga Miranda "foi o primeiro a aventar a ideia de que Noite na taverna poderia ser filiada ao Decameron e seria uma continuação de Macário, antecipando, assim, a hipótese que se costuma atribuir a Antonio Candido em seu "A educação pela noite"'. Para maiores detalhes, cf. OLIVEIRA, Jefferson Donizeti de. Um sussurro nas trevas: uma recepção da recepção crítica e literária de Noite na Taverna, de Álvares de Azevedo. São Paulo: FFLCH-USP, 2010 (Dissertação de mestrado), pp. 29-30.

${ }^{130}$ ALVES, Maria Cláudia Rodrigues, O poeta leitor: um estudo das epígrafes hugoanas na obra de Álvares de Azevedo, 1999, p.85. 
e caligrafia ruim do autor, faltariam trechos comprometidos pela péssima qualidade dos rascunhos de Azevedo, ou mesmo capítulos inteiros que provavelmente desapareceram. $^{131}$

Além das lacunas apontadas por Homero Pires na edição por ele organizada, somam-se ainda as sinalizadas no testemunho do estudioso Péricles Eugênio da Silva Ramos, que lembra o artigo de Vieira Souto, publicado em 1952. Nele, Souto dizia possuir partes inéditas de uma versão de O livro de Fra Gondicário em melhor conservação que os manuscritos da Biblioteca Nacional, além de trechos modificados de $O$ conde Lopo e $O$ poema do frade. ${ }^{132}$ Vieira Souto julgava que O livro de Fra Gondicário era parte de um projeto maior, chamado O Livro de Fra Maffio Sant'Orso, "à vista da folha de rosto do caderno manuscrito de Álvares de Azevedo com o projeto ou índice da obra" ${ }^{\prime 33}$, que Souto teria encontrado. No entanto, Péricles Eugênio relata que Souto falecera antes de publicar o material, perdido após a morte deste.

O caráter fragmentário de O livro de Fra Gondicário é tão pronunciado que até hoje não se pôde interpretar seu título, como ressalta Maria Claudia Rodrigues Alves. ${ }^{134}$ Sua forte impressão de inacabamento é intensificada pelo fato de a obra ser iniciada com a indicação "Terceira parte", chamada "Lábios e Sangue", e com numeração lacunar dos capítulos e sessões, que apontariam para um rascunho inconcluso. Todavia, Antonio Candido desconfia de tal configuração, apontando no material um tipo de organização e efeito provavelmente almejados pelo autor. Segundo o crítico, "parece mais um início de livro, com prólogo em verso, invocação e autonomia fabulativa que o torna bastante a si mesmo". ${ }^{135}$

Neste rápido levantamento dentre as obras de Álvares de Azevedo, é possível observar que o preâmbulo é um espaço de reflexão privilegiado em sua poética. De modo geral, ele desestabiliza os modelos tradicionais do prefácio teórico, e espalha pistas de leitura, muitas vezes não verbalizadas, mas sinalizadas por meio da construção formal peculiar de suas introduções. Por vezes, desloca-se o prólogo para o meio ou para o final de seus poemas, como é o caso de "O Editor", "Boêmios" ou o Canto Primeiro de $O$ poema do frade.

\footnotetext{
${ }^{131}$ PIRES, Homero. "Introdução", in: AZEVEDO, Álvares de. Obras completas de Álvares de Azevedo, organização de Homero Pires. 8. ed. São Paulo: Nacional, 1942, vol. 1, p.28.

132 RAMOS, Péricles Eugênio da Silva. "Introdução". In: AZEVEDO, Álvares de, 2002, p. 24.

${ }^{133}$ Idem, pp. 26-27.

134 ALVES, Maria Cláudia Rodrigues, 1999, p.83.

135 CANDIDO, Antonio, 1987, p. 19.
} 
Durante a presente análise, buscou-se discutir a inserção da proposição de $\mathrm{O}$ poema do frade nas duas estrofes de fechamento do Canto de abertura, com base em outros exemplos encontrados na poética alvaresiana e no romantismo de um modo mais geral. Vale observar que há uma outra parte da proposição de $O$ poema do frade, deslocada em um trecho anterior do mesmo Canto Primeiro, que passa despercebido numa primeira leitura, por estar camuflado entre as tantas digressões desenvolvidas pelo enunciador:

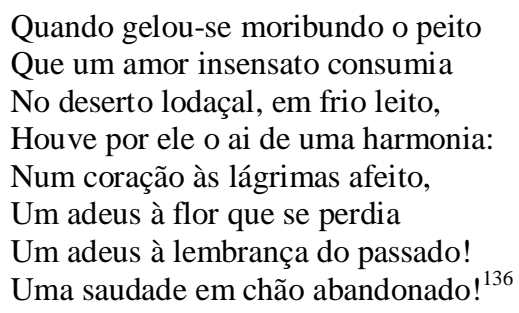

Esta estrofe acima antecipa e resume os acontecimentos que envolvem as personagens Jônatas e Consuelo na passagem do Canto Terceiro para o Quarto, além de ser alusivo à penúltima estrofe do Canto Primeiro, trecho no qual o narrador diz pretender cantar "a glória não sabida" de seu herói, pois Jônatas sucumbe solitário em uma praia deserta. Nesse sentido, esta passagem cumpre, veladamente, parte da função da preposição, no canto de abertura. Entretanto, só é possível perceber esse fato posteriormente, pois no "prólogo" da obra não há qualquer indicação sobre a relação desses versos com um possível enredo desenvolvido posteriormente. ${ }^{137}$ Ao ser misturado a tantas outras digressões, o trecho inicialmente parece contribuir para movimentar mais um dentre tantos devaneios aparentemente gratuitos, do enunciador, sem sugerir implicações mais específicas.

Após a cena na qual Jônatas e Consuelo se encontram e passam a noite juntos narrada no segundo canto de $O$ poema do frade - , as personagens são deixadas de lado durante o longo, e ainda mais digressivo, Canto Terceiro. Neste canto, o foco é voltado para a figura do frade-narrador. Conforme os cantos seguintes avançam, as

\footnotetext{
${ }^{136}$ AZEVEDO, Álvares de, 2002, estrofe XXII.

${ }^{137}$ A personagem Jônatas surge morta numa praia, no final do Canto Terceiro. A possibilidade de suicídio é insinuada, porém não há qualquer narração ou detalhamento dos acontecimentos que levaram a esse resultado. Somente os desdobramentos da cena são aludidos com vagueza. Uma jovem misteriosa também aparece em seguida, sem maiores explicações, e pranteia sobre o cadáver solitário. Adiante, o enunciador confirma ser ela Consuelo. Como a garota soube do paradeiro de Jônatas ou mesmo como transcorreu a morte deste último não são questões respondidas pelo narrador, que evita maiores explicações.
} 
personagens vão perdendo terreno para a figura do próprio frade, que deixa de ser um intruso na ação para ocupar de vez o foco do poema. Em outras palavras, o narrador é incorporado em seu próprio discurso como mais um personagem, dissolvendo os limites que pareciam separar o seu plano autoral daquele dos acontecimentos vividos pelas personagens Jônatas e Consuelo. Em várias passagens, o frade afirma ter presenciado momentos nos quais o casal parece estar sozinho, por meio do emprego dos verbos "ver", “ouvir" ou "sentir" conjugados em primeira pessoa. No Canto Primeiro, há uma cena na qual Jônatas tem a experiência de um pesadelo. Sobre ela, o frade comenta:

\footnotetext{
Uma vez o escutei: todos dormiam -

Junto à mesa deserta e quase escura:

Lembranças do passado lhe volviam;

Não podia dormir! Na festa impura

Fora afogar escárnios que doíam....

Não o pôde: dos lábios na amargura

Ouvi-lhe um murmurar.... Eram sentidas

Agonias das noites consumidas!
}

Olvidei a canção: só lembro dela

Que d'alma a languidez a estremecia $(\ldots)^{138}$

Não se trata de um autor onisciente, ao modo do compositor de epopeias, uma vez que passagens análogas são retomadas nos demais cantos de $O$ poema do frade, de modo a embaralhar ambígua e progressivamente as figuras do herói e do narrador, ambos poetas libertinos, interessados pela mesma beleza contraditória, sintetizada na prostituta Consuelo. Tais passagens serão analisadas com mais vagar nos capítulos seguintes desta dissertação.

Do Canto Terceiro em diante, com a morte precoce do herói, fica evidente que as digressões e devaneios presentes em todo $O$ poema do frade não são elementos marginais, mas antes a força motriz de um discurso que tem o seu fundamento na reflexão e na abstração, em detrimento dos acontecimentos centrados na ação objetiva das personagens, pois o poema continua sem a sua suposta personagem principal. Nesse sentido, o título do poema se justifica: ele não faz referência ao herói, como é o caso de Odisseia e Eneida, derivadas dos nomes de Odisseu e Eneias. Apesar de negar esse fato no Canto Primeiro, o foco do poema alvaresiano em questão é o frade-narrador: ele insiste mais de uma vez na dessemelhança entre ele e a personagem Jônatas: “Acrescento porém... juro o que digo!/Não se parece Jônatas comigo.” Afirmações

${ }^{138}$ AZEVEDO, Álvares de, 2002, estrofes XXXI e XXXII; os grifos são meus. 
como esta criam uma série de falsas expectativas, sistematicamente frustradas nos cantos posteriores do poema.

A figura do frade-enunciador é caracterizada pela escassez de informações, sejam físicas ou biográficas. Ele não possui sequer um nome, diferente de Jônatas ou Consuelo. Somente a sua situação de religioso é amplamente ressaltada, destacada inclusive no título da obra. Este dado o insere numa larga tradição romântica de narradores, discutida mais adiante nesta dissertação. A personagem Jônatas, por sua vez, não tem rosto definido, seus traços físicos são indeterminados; praticamente não age nas poucas cenas em que aparece, para, de repente, surgir já morto na metade do poema, que é continuado sem ele. Apresentação semelhante ocorre com a personagem Consuelo: a moça é descrita ora dormindo, ora tomada pelo delírio paralisante em seus momentos finais. As personagens são construídas no poema alvaresiano em questão por meio de recursos que favorecem o esfumaçamento da narrativa, de modo a torná-la difusa.

Em linhas gerais, O Canto Primeiro, denominado por seu enunciador como o "prólogo" de O poema do frade, é uma introdução construída de forma prolixa e desorientadora. Deslocada, fragmentada, dispersa e acima de tudo não confiável, ela é um espaço de desmonte do preâmbulo convencional. A ironia movimenta os frequentes devaneios e digressões, responsáveis por embaralhar um suposto foco principal e a linearidade do discurso. Ao compor uma introdução na qual se luta contra a explicitação do assunto e a concisão, o Canto Primeiro de $O$ poema do frade se apresenta como um paradoxal anti-prólogo de epopeia, destinado a dificultar a entrada do leitor na obra.

Em um prefácio romanticamente concebido, busca-se problematizar a representação ideal de um conteúdo infinito numa forma finita. A limitação da forma em abarcar o incomensurável acaba por levá-la ao estilhaçamento, ao desordenado. A forma romântica pressupõe a ausência de forma estável. À maneira de Friedrich Schlegel, pode-se dizer que o Canto Primeiro de $O$ poema do frade é um prólogo, mas também não é um prólogo. Este se posiciona diante do leitor como uma espécie de "portinha travessa" levada aos últimos limites; esta expressão foi originalmente utilizada por José de Alencar para criticar o prólogo frustrado da epopeia $A$ Confederação dos Tamoios. No caso de Gonçalves de Magalhães, no entanto, sabe-se que não era sua intenção posicionar uma "portinha travessa" como entrada ao monumento indianista em construção na nação recém-independente, ansiosa por um 
pórtico solene e majestoso, capaz de inseri-la culturalmente dentre as grandes civilizações ocidentais. 


\title{
Capítulo II
}

\section{O livre perambular da imaginação}

\begin{abstract}
As digressões são incontestavelmente a luz do sol; — são a vida, a alma da leitura; - retirai-as deste livro, por exemplo, — e será melhor se tirardes o livro juntamente com ela; - um gélido e eterno inverno reinará em cada página sua; devolvei-as ao autor; - ele se adiantará como um noivo, - e saudá-la-às todas; elas trazem a variedade e impedem que a apetência venha a faltar.
\end{abstract}

Laurence Sterne, A vida e as opiniões do Cavalheiro Tristram Shandy ${ }^{139}$

\section{Movimentos do mar interior}

O discurso do narrador de $O$ poema do frade é marcado pela intensa presença de digressões, nas quais ele tece, sobretudo, reflexões sobre a sua visão de mundo e comenta o seu próprio estilo de escrita. A mescla de considerações metalinguísticas em um poema narrativo instaura um discurso pautado pela descontinuidade e pela multiplicidade de questões em um mesmo espaço textual, fazendo conviver, a um só tempo, a narrativa e a teoria poética. Foi proposta estética do romantismo superar as fronteiras entre os diferentes gêneros artísticos e campos do saber; os contrários deveriam, nesta perspectiva, ser abarcados em um modelo de escrita miscelânico e maleável.

A variedade estilística presente nos textos românticos mimetiza uma "ordem desordenada", que desestabiliza as noções de hierarquia e linearidade na articulação da linguagem; neles, a simultaneidade de pontos de vista simultâneos e contrários mostrase como tentativa de integrar arte e natureza, inteligência e paixão, pensamento e ato da escrita. ${ }^{140}$ Somente uma forma sublime, dotada de grandeza descomunal, pode reunir em si mesma esferas da realidade tão díspares e conflituosas. O sublime, simultaneamente intelectual e sentimental, valoriza a representação dos instantes de aguda crise, gerados

${ }^{139}$ STERNE, Laurence. A vida e as opiniões do cavalheiro Tristram Shandy. Tradução, introdução e notas de José Paulo Paes. Rio de Janeiro: Nova Fronteira, 1984, p. 22.

140 LOMBARDO, Giovanni. "Longino", in: A Estética da Antiguidade Clássica. Lisboa: Editora Estampa, 2002, p.183-187. 
pela movimentação conflituosa e instável de elementos opostos colocados em choque em um mesmo espaço textual. Neste estilo, observa-se uma recorrente exploração de metáforas que mimetizam o livre perambular da imaginação: ela avança, colide, recua, e retoma o seu movimento incessante de superação e aproximação dos contrários. Por meio delas, é possível mimetizar a contemplação dos caminhos percorridos pela reflexão do poeta, durante o seu ato criativo.

São metáforas dessa natureza, em $O$ poema do frade, a "leve canoa" ou o balão que se deixam levar pela oscilação das águas e dos ventos; ou então o cavalo impetuoso, de difícil controle - , todas elas, metáforas extraídas das primeiras estâncias do Canto Primeiro. Analogias entre a imaginação criadora e figuras errantes são explícitas ao longo do poema, como no trecho abaixo, em que o narrador afirma:

\author{
O meu imaginar é um navio \\ Que entre as brisas da noite se perfuma, \\ Que à plácida monção do morno estio \\ Resvala pelo mar à flor da escuma! \\ E da noite no fresco e no arrepio \\ Das vagas a gemer uma por uma \\ Sobre a quilha que lânguida se escoa \\ Os marinheiros vão dormir na proa. ${ }^{141}$
}

Nele, a imaginação do narrador é comparada a um navio levado pelas ondulações marítimas, cujo balançar favorece o sonhar dos marinheiros, na noite perfumada. A imagem de um sujeito devaneante que se deixa levar pelo movimento das águas é recorrente em outras composições da poética alvaresiana. No Canto III de $O$ conde Lopo, por exemplo, a personagem homônima procura um barqueiro que faça a sua travessia no lago, e solicita: "Solta a barca, patrão! A noite é bela/ Quero me ir deslizar por esse vidro/ Do lago adormecido". ${ }^{142}$ Durante a navegação, Lopo se entrega a divagações, que fazem lembrar a famosa passagem de Devaneios de um caminhante solitário, de Jean-Jacques Rousseau, na qual seu narrador afirma:

esquivava-me e ia me atirar sozinho, num barco, com os olhos voltados para o céu, deixava-me estar e derivar lentamente ao sabor da água, algumas vezes durante várias horas, mergulhado em mil devaneios confusos mas deliciosos, e que, sem nenhum objeto bem determinado nem constante, não deixavam de ser, na minha opinião, cem vezes preferíveis a tudo o que encontrara de mais

141 AZEVEDO, Álvares de. "O poema do frade", in: Poesias completas; edição crítica de Péricles Eugênio da Silva Ramos; Iumna Maria Simon (org), Campinas, SP: editora da Unicamp, São Paulo: Imprensa Oficial do Estado, 2002, Canto Primeiro, estr. XVII, p. 311.

${ }^{142}$ Idem, "O conde Lopo", in: 2002, p.439. 
doce no que chamam os prazeres da vida. ${ }^{143}$

A confusão dos devaneios é encarada como elemento positivo, tal como a sua indeterminação: o sujeito não se fixa em "nenhum objeto bem determinado nem constante", derivando livremente, sem destino definido.

Durante as meditações de Lopo, a personagem criada por Álvares de Azevedo, pondera, não por acaso, sobre o tema da insuficiência da linguagem articulada, incapaz de exprimir satisfatoriamente determinados estados de alma, instáveis e fugidios, de difícil definição: "Quem na aridez das línguas traduzisse/ O quanto devaneio lhes corria/ Então na ideia d'ouro da ventura?"; ou ainda, "não podem/ Pálidas rimas traduzir enlevos/ D'alma divinizada. - Só os anjos/ Coa voz suave no frescor do empíreo/ Sabem hinos assim soar nos lábios!",144

Em O livro de Fra Gondicário, outra composição alvaresiana, os movimentos da alma e aqueles do navio são também comparados de maneira explícita: "Mas ao assunto. Minha imaginação é um navio de velas brancas que ao desfraldar o vento livre enfuna e incha". Seu narrador se dispersa ao descrever este navio, e compara o capitão da embarcação imaginária ao poeta Almeida Garrett, sentado em "posição dúbia e agradável". Após um longo devaneio, que inclui citações, comparações e imagens poéticas, despertadas pela imensidão do cenário marítimo, ele termina parte do segundo capítulo simulando uma tentativa de ater-se ao enredo:

E pois voa também minha imaginação como uma gaivota do mar...

Eis-me perdido outra vez — onde estou? Que dizia? — Basta de divagar. Ao assunto $^{145}$.

A comparação do processo criativo com um repertório de metáforas náuticas é uma "praxe introdutória" nos textos antigos e medievais, conforme aponta Ernst Robert Curtius. Esse conjunto de metáforas pode ser encontrado, por exemplo, em Horácio, Virgílio, Cícero e Dante; dentre os poetas romanos, é recorrente a comparação do processo de composição da obra literária com uma viagem marítima: "Compor é 'fazerse à vela, velejar". No início do discurso, o poeta solta as velas, recolhendo-as ao seu

${ }^{143}$ ROUSSEAU, Jean-Jacques. Devaneios de um caminhante solitário. Tradução de Fúlvia Maria Luiza Moretto. Brasília: UNB, 1986. Cf. a Quinta Caminhada, p. 74.

${ }_{144}^{144}$ AZEVEDO, Álvares de. "O conde Lopo", in: 2002, pp. 440-441.

${ }^{145}$ Idem, "O Livro de Fra Gondicário", in: Obra completa, BUENO, Alexei (org.) Rio de Janeiro: Nova Aguilar, 2000, p. 183-184. 
término: "O poeta torna-se marinheiro; e seu espírito ou sua obra, o barco". ${ }^{146}$ No Canto Terceiro de $O$ poema do frade, há uma passagem na qual a analogia fica evidente:

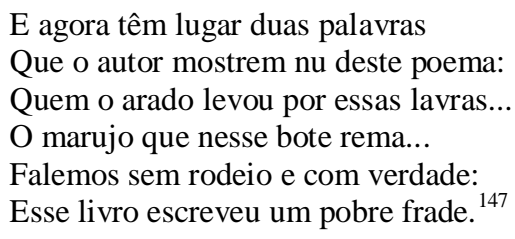

Na passagem, o enunciador se compara, entre outras figuras, ao marujo, ao passo que a sua obra é o bote; conduzir a sua escrita é como remar. Curtius ainda destaca na tradição das metáforas náuticas o constante tema da viagem perigosa em águas tormentosas, potencializada pela inexperiência do nauta, ou pela fragilidade de seu batel. As metáforas do "barco do espírito" obedecem a um esquema de proporção e harmonia fundamentado na hierarquia clássica dos gêneros literários. No poema épico, figuram o mar imenso e a embarcação grandiosa; na lírica, a modesta canoa singra rios e lagos: "O poeta épico viaja num grande navio sobre o largo mar; o lírico numa pequena canoa e pelo rio". ${ }^{148}$ Já em $O$ poema do frade, a proporção fundamentada na hierarquia dos gêneros clássicos se embaralha, uma vez que o narrador compara a sua lide poética a uma embarcação precária, arrebatada pela força descomunal da tempestade marítima. Trata-se da desproporção violenta característica do estilo sublime, que concebe a fantasia criadora como força descomunal a ser intelectualmente formulada pelo artista:

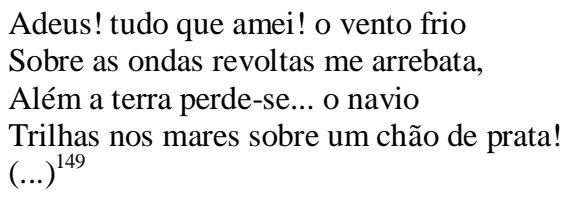

Rüdiger Safranski comenta sobre a tradição "das grandes partidas e errâncias” na literatura ocidental, cuja origem remete à Odisseia e ao mito dos Argonautas, durante a Antiguidade. O tema do deslocamento sobre as águas tem continuidade na Idade Média com a alegoria da Nau dos insensatos, cujos caminhos, traçados pelo destino, são desconhecidos pelo ser humano. Já no romantismo, o tema da "viagem sem chegada e

${ }^{146}$ CURTIUS, Ernest Robert. Literatura Europeia e Idade Média Latina. São Paulo: Hucitec/Edusp, 1996, p.177-178.

${ }^{147}$ AZEVEDO, Álvares de. “O poema do frade”, in: 2002, Canto Terceiro, estr. VI, p. 326.

${ }^{148}$ CURTIUS, Ernst Robert, 1996, p.177.

149 AZEVEDO, Álvares de. "O poema do frade", in: 2002, Canto Quinto, estr. XXXVIII, p. 358. 
sem destino, a viagem infinita portanto", se afasta do modelo clássico, no qual Ulisses, por exemplo, se empenha em concluir um destino determinado. Para Safranski, a concepção de viagem sem fim dos românticos tem continuidade em poemas como $O$ barco ébrio, de Rimbaud ${ }^{150}$, que, em seu vagar dionisíaco, acaba por mesclar as metáforas náuticas com as da bebida, frequentemente associadas à fantasia poética. ${ }^{151}$ Se a viagem de Ulisses consistia em uma trajetória objetiva, a peregrinação moderna sobre as águas é subjetivada: ocorre no fluxo da mente do poeta.

Giovanni Lombardo discute a analogia entre as "tempestades do mar e as tempestades do coração" como tema característico do estilo sublime. Segundo ele, o poeta, tomado pelo pathos, simula o caótico movimento das ondas do mar como metáfora equivalente a seu pensar, arrebatado pela inspiração; ele seleciona e representa em sua escrita o momento de crise mais aguda desse processo, buscando "dissolver o enunciado no ato", isto é, tentando representar a sensação de simultaneidade do processo criativo experimentada em sua escrita. O efeito torna-se mais forte caso seja representado como vivência presente, a ser experimentada também pelo leitor. Neste sentido, o artista empenha-se na composição de uma "ilusão da simultaneidade das emoções", que busca fundir pensamento e escrita, e abarcar até mesmo o leitor, posteriormente, em uma mesma experiência poética, tal como se este último pudesse também participar da tensão que envolve o processo criativo. ${ }^{152} \mathrm{O}$ artista compõe um discurso repleto de contrastes, mudanças bruscas de assuntos ou estilos, articulados em uma linguagem caracterizada pela "ordem desordenada". Assim, não somente a movimentação marítima, mas a violência da erupção vulcânica e a instabilidade das nuvens no céu, remetem aos ciclos de instabilidade da mente criativa, em sua luta para domar a fantasia e encontrar uma forma articulada satisfatória e inteligível. Ao simular uma escrita espontânea, na qual a inspiração apaixonada e o trabalho técnico de composição artística coincidem, em um todo orgânico e simultâneo, o estilo sublime forja uma "arte disfarçada de natureza". ${ }^{153}$

\footnotetext{
${ }^{150}$ SAFRANSKI, Rüdiger. "Capítulo XI”, in: Romantismo: uma questão alemã. Tradução de Rita Rios. São Paulo: Estação Liberdade, 2010, p. 194.

${ }^{151}$ As metáforas etílicas em $O$ poema do frade são objeto de análise, mais adiante neste capítulo.

152 “o sublime autêntico (...) exalta-lhe a paixão e a inteligência, desperta-lhe grandes pensamentos e imprime-se-lhe o indelével na mente: assim ele [o leitor] se identifica com o autor e revive a urgência interior que produziu o texto". $C f$. LOMBARDO, Giovanni. "Longino", in: A Estética da Antiguidade Clássica. Lisboa: Editora Estampa, 2002, p. 182.

${ }^{153}$ Idem, p. 188.
} 
$\mathrm{Na}$ "Invocação" a Byron, por exemplo, presente no poema alvaresiano $O$ conde Lopo, a força dos mares, ventos e tempestades são mobilizados na caracterização do estilo sublime do bardo inglês:

Foste poeta, Byron! a onda uivando

Embalou-te o cismar - e ao som dos ventos

Das selváticas fibras de tua harpa

Exalou-se o rugir entre lamentos!

(...)

A ti meu canto pois - cantor das mágoas

De profunda agonia! - a ti meus hinos,

Poeta da tormenta - alma dormida

Ao som do uivar do oceano,

Bardo sublime das Britânias brumas! ${ }^{154}$

Para um romântico, a imagem do mar, de modo geral, evoca a ideia de vastidão infinita, potencializada ao mesclar-se com o céu, para além da linha do horizonte. Friedrich Schiller afirma que a "visão de distâncias ilimitadas e de alturas intermináveis, o extenso oceano a seus pés e o maior oceano acima dele, arrancam o seu espírito à estreita esfera da realidade e ao opressivo cativeiro da vida física". ${ }^{155} \mathrm{O}$ ideal de transcender limites e fronteiras está de acordo com a concepção de "poesia universal progressiva" de que Friedrich Schlegel fala, na ânsia pela reunificação entre poesia e prosa, poesia e ciência, poesia e vida. A visão do incomensurável despertada pelo espelhamento do céu no mar põe em movimento a consciência do sujeito, a um só tempo tomado pela beleza desejada do horizonte azul, e pelo desconforto ao se perceber pequeno e limitado diante da enormidade da dimensão contemplada: o sentimento resultante dessa visão é misto de deleite e dor. A sensação de "desassossego" decorrente impele o sujeito ao movimento, como é próprio do sublime. O romântico carrega o sentimento de incompletude e o desejo pelo infinito, que o "impulsiona para regiões distantes e desconhecidas"156, sempre mais além. O artista clássico, por sua vez, mantém-se em "serena quietude", uma vez que o belo está em harmonia e unidade consigo mesmo. ${ }^{157}$ Em contrapartida, o artista romântico se fragmenta e se dispersa; na

${ }^{154}$ AZEVEDO, Álvares de. "O conde Lopo", in: 2002, p 427-.428

${ }^{155}$ SCHILLER, Friedrich. "Acerca do sublime", in: Teoria da tragédia. Introd. e notas de Anatol Rosenfeld. São Paulo: EPU, 1991, p. 61.

${ }^{156}$ SAFRANSKI, 2010, p. 191.

${ }^{157}$ Cf. WINCKELMANN, J. J. Reflexões sobre a arte antiga. Estudo intr. de Gerd A. Bornheim. Trad. de Herbert Caro e Leonardo Tochtrop. Porto Alegre: Movimento/ Universidade Federal do Rio Grande do Sul, 1975. 
impossibilidade de ser uno e inteiro, ele torna-se irônico: sua cisão torna-se espelho esfacelado do eu reflexivo em diálogo consigo mesmo.

A presença do horizonte marítimo é uma constante na poética alvaresiana; Antonio Candido aponta, na combinação estabelecida pelo poeta entre o mar, o vento e a lua, um efeito de infinitude e liberdade. ${ }^{158}$ Os olhos românticos acompanham o jogo de fluxo e refluxo promovido pelos incessantes movimentos das marés; o grande oceano é uma lembrança fugaz do absoluto: "o absoluto não é totalidade ordenada mas antes o caos. Ele só pode ser pressentido, adivinhado, revelado e logo de novo perdido". ${ }^{159} \mathrm{O}$ mar na poética de Álvares de Azevedo convida ao cismar e ao sono, embalado por sonhos. Por vezes é a noite fresca que o acompanha, noutras é a tempestade pavorosa, que remete ao estilo sublime, cuja grandeza descomunal abarca o misto de deleite e horror.

A relação entre a vastidão do mar e a noção de infinitude da alma foi objeto de discussão de Marco Aurélio Werle; ele parte do repertório de metáforas marinhas associadas à analogia entre a criação estética e concepção de linguagem no idealismo alemão, com base nos apontamentos encontrados em Leibniz, Winckelmann, Herder, Goethe, Kant e Schiller. ${ }^{160}$ Segundo Werle, as metáforas marinhas evocam potências da mente humana antes relegadas, tais como os afetos e demais manifestações inconscientes e profundas, que escapam ao domínio da razão. A elas, vincula-se a tendência aos devaneios, o "delírio viajante", resultado do entusiasmo gerado pela "ideia de abraçar o universo" em sua totalidade. Entre os autores acima citados por Werle, Kant valoriza a imagem da terra firme em detrimento do fascínio gerado pelo oceano. Para Kant, o entendimento é uma ilha circunscrita e bem delimitada, a partir da qual é possível encarar, com segurança, as ilusões do "oceano tenebroso". O pensador rigoroso e sensato permanece na ilha,

envolta por um vasto e tempestuoso oceano, a verdadeira sede de ilusão, onde muito nevoeiro e muito gelo, em ponto de liquefazer-se, permitem imaginar falsamente novas terras e, enquanto iludem com vãs esperanças o navegador que vagueia sem rumo a procura de novas descobertas, enredam-

158 CANDIDO, Antonio. “Álvares de Azevedo: Ariel e Caliban”, in: In: Formação da literatura brasileira: momentos decisivos. Rio de Janeiro / Belo Horizonte: Itatiaia, 1993, v.2, p1993, p. 166.

159 D’ANGELO, Paolo. A estética do romantismo. Tradução Isabel Teresa Santos. Lisboa: Estampa, 1998, p. 111.

160 WERLE, Marco Aurélio. "O mar e a alma: metáforas marinhas em território alemão". In: Trans/Form/Ação, vol. 30, n. 1, São Paulo, 2007, p. 225. 
no em aventuras das quais não poderá jamais desistir e tampouco terminálas. $^{161}$

Kant, Werle assinala, prefere a resignação e a precaução do território verificado (a filosofia, a verdade, a razão), ao risco de ficar à deriva, gerado pelo impulso rumo à ilusão tentadora (a arte). Entretanto, o insistente insulamento kantiano torna mais intensa a tentação de lançar-se para fora dele, conforme sugere Goethe: "Kant deliberadamente se limita a um certo círculo e sempre aponta ironicamente para além dele". ${ }^{162}$ A afirmação do autor de Fausto, a respeito da rigorosa delimitação kantiana, faz pensar na célebre definição cunhada por Friedrich Schlegel para a poesia romântica, entendida como fragmento: "Um fragmento tem de ser como uma pequena obra de arte, totalmente separado do mundo circundante e perfeito e acabado em si mesmo, como um porco-espinho". 163 A obra de arte é formulada como uma miniatura ensimesmada, mas ironicamente voltada à todas as direções do mundo que a cerca, tal como os espinhos espalhados sobre a superfície do animal citado; a arte afirma a sua autonomia em relação ao mundo, mas também a sua determinação recíproca perante o mesmo.

De acordo com Marco Aurélio Werle, Friedrich Schiller assinala a impossibilidade de desfrutar, na modernidade, do sentimento de repouso, assentado sobre a "nobre simplicidade e calma grandeza" da plástica grega, de que fala Winckelmann. Para sugerir o impulso ao movimento contínuo na arte moderna, Schiller cita uma imagem marítima, extraída de um episódio de Les aventures de Télemaque, fils d'Ulysse (1698), de Fénelon:

\footnotetext{
A beleza, sob a figura de Calipso, enfeitiçou o valente filho de Ulisses, e graças ao poder de seus atrativos mantém-no longo tempo prisioneiro em sua ilha. Por muito tempo acredita ele estar prestando culto a uma imortal divindade, quando na verdade apenas repousa nos braços da volúpia; mas, sob a figura de Mentor, uma impressão sublime comove-o de repente; ele se lembra de sua destinação superior, lança-se às ondas e é livre. ${ }^{164}$
}

Assim como Telêmaco, filho do clássico Ulisses, o artista romântico se lança ao desconhecido, mas sem qualquer garantia de chegada ou de conclusão de sua meta; em

161 KANT apud WERLE, 2007, p.232.

162 GOETHE, apud WERLE, 2007, idem.

${ }^{163}$ SCHLEGEL, Friedrich,1997, p. 82.

${ }^{164}$ SCHILLER, apud WERLE, 2007, p. 233. 
sua infinita tarefa de superação de distâncias e barreiras, ele promove o encontro fugaz e violento dos contrários. ${ }^{165}$

\section{Arabescos no ar}

A disposição do narrador de $O$ poema do frade a contemplar os livres movimentos de seu pensar surge também associada à fumaça, em especial àquela produzida por seu charuto. No Canto Terceiro, o frade-narrador descreve o prazer obtido na visão das formas inesperadas e transitórias assumidas pelo fumo, responsáveis por estimular a sua imaginação e propiciar a atmosfera ideal para os seus devaneios. Os desenhos descontínuos espalhados pelo ar assemelham-se à escrita em arabesco, pois mimetizam os movimentos infinitos da "reflexão poética": o livre curso da fantasia gera, assim, uma "superabundância de pensamentos"166, responsável por simular a impressão de excesso e desmesura por meio da multiplicação intensa de metáforas, que se desdobram de modo prolixo umas das outras, como se buscassem uma forma satisfatória, capaz de superar as limitações da linguagem escrita.

Em O poema do frade, os vapores da fumaça sugerem imagens incorpóreas, ligadas ao idealismo, tais como a "trêmula nuvem azulada" e a "virgem vaporosa":

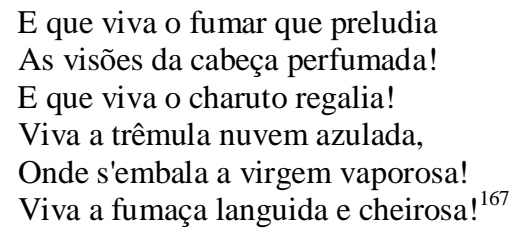

O frade-enunciador da obra em estudo acaba por desenvolver uma espécie de breve poética do charuto no Canto Terceiro. Ali, o objeto prosaico é elevado à esfera do ideal, sintetizando em si uma beleza simultaneamente sensual e etérea:

Oh! meu Deus! como é belo entre a fumaça

No delicioso véu que as anuvia

Ver as formas lascivas da donzela

Entre o véu transparente que esvoaça,

\footnotetext{
165 A imagem do oceano em $O$ poema do frade é retomada no quarto capítulo desta dissertação.

166 LOMBARDO, Giovanni. "Longino", in: A Estética da Antiguidade Clássica. Lisboa: Editora Estampa, 2002, p. 184.

${ }^{167}$ AZEVEDO, Álvares de. "O poema do frade”, in: 2002, Canto Terceiro, estr. IX, p. 326.
} 
Nadando nesse vaporoso dia

Bailando nua, voluptuosa e bela! ${ }^{168}$

A imagem da donzela voluptuosa desdobra-se da fumaça, instaurando uma atmosfera de imprecisão e mutabilidade, mediada pelas imagens do "véu transparente" e do "vaporoso dia". Tal procedimento poético auxilia no engendramento das cadeias digressivas do narrador-frade, uma vez que os movimentos transitórios, mas incansáveis, da fumaça são análogos à sua escrita descontínua, devaneante e inacabável:

E quando os lábios o charuto finda E a lânguida visão num beijo passa, E o perfume os cabelos nos repassa, Como é belo no azul da nuvem linda Entre vapores madornar, e ainda A vida renascer noutra fumaça! ${ }^{169}$

Os pensamentos se deslocam e encadeiam-se infinitamente na mente do poeta, que pode ir e voltar de um extremo a outro, pular um assunto, interrompê-lo, lembrar trechos de maneira parcial, num processo que nunca estará terminantemente acabado. Forma-se uma rede de epígrafes, citações, sensações e impressões, todas misturadas em uma atmosfera fugaz. O poeta, movido pela autorreflexão infinita, não se fixa por muito tempo em nenhum ponto; pois a reflexão é movimento: a ironia é "a consciência clara da eterna agilidade, do caos infinitamente pleno". ${ }^{170}$

Antonio Candido destaca na poética de Álvares de Azevedo um repertório recorrente de palavras como "palor", "palidez", "suores", "névoas" e "vapores", que conotam ideias de "esvaecimento" e "inconsistência":

\footnotetext{
É, por toda a sua obra, uma sensação geral de evanescência, de passagem do consciente ao inconsciente, do definido ao indefinido, do concreto ao abstrato, do sólido ao vaporoso, que aparece na própria visão da natureza, na qual opera uma espécie de seleção, elegendo os aspectos que correspondem simbolicamente a estes estados do corpo e do espírito - como é o caso das névoas e vapores $(. . .)^{171}$
}

Alcides Villaça também indica uma conexão similar em análise do soneto "Pálida à luz da lâmpada sombria". Nele, o eu lírico contempla a imagem feminina ideal, adormecida entre nuvens e névoas, mas que revela aos poucos a sua materialidade

\footnotetext{
168 Idem, idem, estr. XI, p. 327.

169 Idem, idem, estr. XIII, p. 327.

${ }^{170}$ SCHLEGEL, Friedrich. O dialeto dos fragmentos, 1997, p.153.

${ }^{171}$ CANDIDO, Antonio. “Ariel e Caliban”, in: Formação da Literatura Brasileira, 1993, p. 165.
} 
sensual. ${ }^{172} \mathrm{O}$ mesmo crítico lembra uma passagem de um dos poemas de "Spleen e Charutos", no qual a amada é descrita como "leviana e bela/ Como a leve fumaça de um charuto". Cilaine Alves Cunha, por sua vez, já havia apontado o vínculo entre a fumaça e a embriaguez, presente na caracterização do ambiente, com o idealismo romântico na abertura de Noite na taverna: "Bertram toma o fumo e o vinho como metáforas do idealismo ou, noutras palavras, como imagem do movimento da ideia pelo pensamento". ${ }^{173}$ Os estados oníricos e delirantes são somados a esta mesma atmosfera fumacenta na poética de Álvares de Azevedo, conforme será considerado mais abaixo neste capítulo.

A relação entre a reflexão abstrata e a representação em arabesco foi comentada por Hugo Friedrich. Segundo ele, românticos como Friedrich Schlegel e Novalis, por exemplo, apontam na abstração a essência da fantasia. Esta "faculdade de criar o irreal" se manifesta frequentemente por meio das formas do arabesco e do grotesco:

Entrevem-se aqui outros pontos de partida da poesia e da arte abstrata, extraídos do conceito de uma fantasia ilimitada, cujo equivalente são as linhas e os movimentos livres do objeto. Baudelaire chama estes últimos "arabescos" - também este um conceito que terá futuro. "O arabesco é o mais espiritual de todos os desenhos". Grotesco e arabesco haviam sido aproximados mutuamente por Novalis, Gautier, Poe. Baudelaire aproxima-os ainda mais. Em seu sistema estético, estão relacionados grotesco, arabesco e fantasia: esta última é a capacidade de movimentos abstratos do espírito livre, isto é, independente de todo objeto; os dois primeiros são produto dessa capacidade. $^{174}$

O arabesco é composto de "linhas livres de qualquer sentido", ou, conforme define Paolo D’Angelo, “ornamentos pictóricos não figurativos obtidos mediante o entrelaçado e a engenhosa combinação de linhas". ${ }^{175}$ Para Friedrich Schlegel, o arabesco é "a forma mais antiga e original da fantasia humana", ideal buscado pela obra de arte romântica. ${ }^{176}$ A expressão "grotesco" também tem seus antecedentes na pintura, designando formas geradas pelo "entrelaçamento ornamental" de cunho fabuloso ${ }^{177}$ _, “grotescas’ eram aquelas decorações antigas em entrelaçados vegetais, formas animais

\footnotetext{
${ }^{172}$ VILLAÇA, Alcides. "O riso de um soneto”, in: Todas as Letras, Revista de Língua e Literatura. São Paulo, n. 1, 1999.

${ }^{173}$ CUNHA, Cilaine Alves. Entusiasmo indianista e ironia byroniana. Tese de doutorado. FFLCH/USP. São Paulo, 2000, p. 306.

${ }^{174}$ FRIEDRICH, Hugo. Estrutura da lírica moderna: da metade do século XIX a meados do século XX. São Paulo: Duas Cidades, 1978, p.57.

${ }^{175}$ D’ANGELO, Paolo, 1998, p. 113.

176 SCHLEGEL, Friedrich. Conversa sobre poesia e outros fragmentos, Tradução, prefácio e notas: Victor-Pierre Stirnimann, São Paulo, Iluminuras, 1994, pp. 55.

${ }^{177}$ FRIEDRICH, Hugo, 1978, p.33.
} 
fantásticas, motivos estilizados, que, descobertos nas criptas [grotte] romanas, se tinham difundido na pintura do Renascimento". ${ }^{178}$ Até o século XVIII, a noção de grotesco era atrelada também às noções de bizarro, jocoso, burlesco, distorcido, estranho; para os artistas modernos, "O grotesco deve aliviar-nos da beleza e, com sua 'voz estridente', afastar sua monotonia". ${ }^{179}$ Esse procedimento vai de encontro com a concepção da poesia moderna, não como representação do belo em "serena quietude", mas do "interessante": ela deve ser intensa e expressiva, repleta de contrastes. Em resumo:

Arabesco e Grotesco designam então a forma fantástica, livre, imprevisível, que torna manifesta aquela 'plenitude infinita' que o witz evocava. Por isso são 'arabescas' ou 'grotescas' aquelas obras literárias em que tal forma fantástica se revela, por assim dizer, no estado mais puro, mais perfeito e acabado. $^{180}$

"Fantástico" é, para Schlegel, inerente à definição de "romântico": "Pois segundo meu ponto de vista e no meu modo de falar, romântico é justamente o que nos apresenta um conteúdo sentimental em uma forma da fantasia". ${ }^{181} \mathrm{O}$ arabesco e o grotesco são manifestações concretas dessa forma fantástica, que procura abarcar o ideal, perseguido pela poesia sentimental. Valoriza-se o indefinido e o indeterminado das imagens eleitas em contraposição à forma fechada e estável, uma vez que 'à 'coisa' teorizada deve efetivamente compreender uma forma da abordagem que saiba apresentar em primeiro lugar, em si mesma, os traços da teoria". ${ }^{182}$

Segundo Hugo Friedrich, a lírica moderna é uma resposta à mimética clássica de representação do mundo objetivo. Ela se torna menos descritiva e narrativa, abalando as noções espaciais, temporais e causais valorizadas no gênero épico. ${ }^{183}$ A lírica moderna passa a decompor e deformar a realidade, instaurando novos mundos de acordo com suas próprias leis: "A realidade desmembrada ou dilacerada pela violência da fantasia jaz na poesia como campo de ruínas". ${ }^{184}$ A lírica moderna se torna em certo aspecto sinônimo de deformidade, estranhamento, dissonância, obscuridade. Ela sobrepõe o trabalho formal em detrimento do foco em um conteúdo comunicável; o poeta ensimesmado se manifesta por meio de monólogos, e não mais se compromete com a

178 D’ANGELO, 1998, p. 114.

179 FRIEDRICH, Hugo, 1978, p.33.

${ }^{180}$ D'ANGELO, 1998, p. 114.

${ }^{181}$ SCHELGEL, Friedrich, 1994, p. 65. Sobre a noção de sentimental, cf. SCHILLER, F. Poesia ingênua e sentimental. Trad. Márcio Suzuki. São Paulo: Iluminuras, 1991.

${ }^{182}$ D'ANGELO, 1998, p. 115.

${ }^{183}$ FRIEDRICH, Hugo, 1978, p.194.

${ }^{184}$ Idem, idem, p.211. 
compreensibilidade de sua obra, cada vez mais alusiva, indireta — , difícil, hostil. ${ }^{185} \mathrm{O}$ poeta moderno é consciente de seu paradoxal anseio de representação do "invisível no visível" — ou do infinito no finito. O eu ensimesmado, tomado como auditório interior possível, se fragmenta e contempla os próprios procedimentos: "o espírito romântico parece fantasiar agradavelmente sobre si mesmo". ${ }^{186}$

As digressões reflexivas são o motor de um dos mais consagrados poemas de Álvares de Azevedo: "Ideias Íntimas". Em análise dedicada a este poema, denominada "Devaneios de um Estudante Solitário", Vagner Camilo chama a atenção para o talhe meditativo que caracteriza esta composição. Nela, o emprego do decassílabo branco favorece a representação das "modalizações de uma consciência entregue à reflexão", e permite o "livre andamento, próximo ao da prosa", acentuado pela predominância das construções sintáticas em ordem direta. Vagner Camilo destaca o subtítulo do poema, denominado "Fragmento" 187 , princípio a partir do qual são mantidas a autonomia e a unidade nos diferentes blocos que formam o poema, conjugando tons e assuntos diversos, guiados pelas oscilações de uma mente devaneante. Simula-se a "aparência de espontaneidade, da ideia fugaz colhida num instante de alumbramento e logo registrada numa escritura propositadamente desatada, para preservar, assim, o frescor e o senso de mistério". As ideias se dispersam no poema "como se elas fossem registradas ao mesmo tempo em que afloram à consciência", orquestradas pela "espontaneidade aparente" e a "perfeita articulação das partes". ${ }^{188}$

A postura contemplativa do eu poético não é passiva, mas criadora, capaz de remodelar e recriar a realidade com base em suas sensações e memórias. ${ }^{189}$ Esse dobrarse sobre si mesmo é modulado pela ironia romântica, tornando o sujeito o objeto de seu próprio olhar. Em "Ideias Íntimas", a mobilidade do pensamento se vincula à mobilidade física do eu lírico, que vagueia pelo quarto e direciona o seu olhar para os objetos ali espalhados. Baseando-se em apontamentos tecidos por Antonio Candido em "O poeta itinerante", Vagner Camilo lembra que desde o pré-romantismo inglês é possível observar um vínculo essencial entre a reflexão e o espaço, por meio da figura

\footnotetext{
${ }^{185}$ Idem, idem, p. 198.

186 SCHLEGEL, apud BENJAMIN, Walter. O conceito de crítica de arte no romantismo alemão. São Paulo. Editora Iluminuras, 1999, p. 29.

${ }^{187}$ CAMILO, Vagner. "Devaneios de um estudante solitário", in: Risos entre pares: poesia e humor românticos. São Paulo: Edusp, 1997, pp. 76-77.

188 Para Alcides Villaça, o poema "Ideias Íntimas" tem sucesso em conjugar um discurso simultaneamente fragmentado e unificado. Cf. VILLAÇA, Alcides. "Na intimidade romântica", in: AZEVEDO, Álvares de. Lira dos vinte anos. São Paulo: FTD, 1994, p. 19.

189 CAMILO, 1997, p.82.
} 
do poeta em trânsito: a predileção pelos passeios e caminhadas como temas propícios à meditação se faz presente em obras como Devaneios de um caminhante solitário, de Jean-Jacques Rousseau, e poemas como "Sub Tegime Fagi", de Castro Alves; mas diferente deste último, o eu lírico de "Ideias Íntimas" não busca inspiração no contato com a natureza, mas se desloca pelo estreito espaço de seu quarto. É interessante pensar na escolha de um local fechado, ocupado por nuvens produzidas artificialmente pelo cigarro, como bem destaca Camilo. Neste microcosmo, o sujeito pode divagar por seus "sonhos diurnos", com os olhos abertos.

Curiosamente, "Ideias Íntimas" acaba justamente no momento em que o eu poético começa a escrever um poema: "Mas poderíamos indagar: escrever o quê? O poema, que já está pronto?". ${ }^{190}$ Nesta perspectiva, a reflexão sobre o fazer produz o fazer em si: se realiza enquanto ensaio. O espaço diminuto do quarto de estudante, descrito no poema, é relacionado também por Alcides Villaça ao tema da criação artística, na passagem: "Como outrora do mundo os elementos/ Pela treva jogando cambalhotas,/ Meu quarto, mundo em caos, espera um Fiat!". ${ }^{191}$ A analogia entre a criação poética e a gênese do universo é um tema comum ao estilo sublime, conforme será discutido mais abaixo, neste capítulo.

Ainda a respeito de "Ideias Íntimas", Vagner Camilo comenta a relação entre a cadência da poesia de Lamartine e a ideia de "rotinização", analogia citada na abertura do poema alvaresiano em questão. O eu lírico associa o "ecoar monódico da lira lamartiniana, aprisionada num ir e vir incessante entre amor e Deus", a uma "eterna mesmice", identificada com o repetitivo som das ondas. ${ }^{192}$ As estrofes do poema de Álvares de Azevedo introduzem primeiro alguns versos que remetem ao tema da monotonia, criticado posteriormente ao se contrastar com o estilo oscilante e fragmentário da escrita alvaresiana:

\section{I}

Ossian o bardo é triste como a sombra Que seus cantos povoa. O Lamartine É monótono e belo como a noite, Como a lua no mar e o som das ondas Mas pranteia uma eterna monodia, Tem na lira do gênio uma só corda, Fibra de amor e Deus que um sopro agita:

\footnotetext{
${ }^{190}$ CAMILO, 1997, p. 94.

${ }^{191}$ VILLAÇA, 1994, p. 19.

${ }^{192}$ CAMILO, 1997, p.79.
} 
Se desmaia de amor a Deus se volta,

Se pranteia por Deus de amor suspira. ${ }^{193}$

Na lira de Lamartine há "uma só corda", uma "eterna monodia" dedicada aos mesmos temas: Deus e amor. No entanto, Lamartine é sucedido por Shakespeare e Hoffmann; deve-se lembrar que, para Azevedo, Shakespeare é por excelência o escritor dos versos irregulares e selvagens, como bem atesta o prefácio de Macário, por exemplo. Já Hoffmann é o autor "ardente" vinculado ao fantástico. Suas formas extravagantes contrastam com o canto "monótono e belo" de Lamartine:

\footnotetext{
Basta de Shakespeare. Vem tu agora, Fantástico alemão, poeta ardente Que ilumina o clarão das gotas pálidas Do nobre Johannisberg! Nos teus romances Meu coração deleita-se... Contudo Parece-me que vou perdendo o gosto, Vou ficando blasé, passeio os dias Pelo meu corredor, sem companheiro, Sem ler, nem poetar. Vivo fumando. ${ }^{194}$
}

O tom impetuoso presente nos primeiros versos desta estrofe, alusivos ao fantástico, arrefece em sua metade, com a conjunção adversativa "contudo", quando o eu poético torna-se "blasé", em um constante oscilar que se estende por longas e desiguais estâncias, conduzidas pelo eu lírico divagante, que "passeia" entre os objetos bagunçados de seu quarto, misturados a lembranças e sensações. Considerações sobre a literatura também se mesclam às imagens de ordem variada, tais como as nuvens de fumo que se dispersam no ambiente, gerando um ambiente onírico:

\footnotetext{
Minha casa não tem menores névoas Que as deste céu d'inverno... Solitário Passo as noites aqui e os dias longos; Dei-me agora ao charuto em corpo e alma; Debalde ali de um canto um beijo implora, Como a beleza que o Sultão despreza, Meu cachimbo alemão abandonado! Não passeio a cavalo e não namoro; Odeio o lansquenê... Palavra d'honra: Se assim me continuam por dois meses Os diabos azuis nos frouxos membros, Dou na Praia Vermelha ou no Parnaso. ${ }^{195}$
}

193 AZEVEDO, Álvares de. "Ideias Íntimas", in: Lira dos vinte anos, 2002, p.152.

${ }^{194}$ Idem, idem, idem.

${ }^{195}$ Idem, idem, pp. 152-153. 
Álvares de Azevedo faz uma crítica à monotonia poética, muito semelhante a esta observada no poema "Ideias Íntimas", no ensaio "Literatura e civilização em Portugal", no qual desaprova o repetitivo "melodioso lamartiniano" presente nos poemas do escritor português Mendes Leal:

é de lamentar ao melodioso lamartiniano das Meditações, da "Sonhei-a", das "Indianas", da "Rosa Branca" e tanta poesia linda, é a pobreza de enredo, a monotonia das suas heroínas: é sempre a mesma beleza (...)

São sempre as virgens alvas (...). Sempre as donzelas tristes como lírios pendentes ao peso da chuva como as sonha Lamartine e Alfredo de Vigny (....). Elas são todas belas, sim, mas belas de uma beleza monotipa; porém esse ressaibo da pobre amante louca da "Rosa Branca", do "Sonho da vida", a sombra suavíssima e cândida que lhe trava de todas as criações, tornam-se monótonas, porque ao som mais doce, a sensação mais suave, se não mudarse dela, arrefece e torna-se insípida. ${ }^{196}$

No mesmo ensaio, Álvares de Azevedo propõe a valorização da literatura universal, em contraposição ao nacionalismo predominante no romantismo brasileiro. $\mathrm{O}$ poeta estima a variedade de fontes, refutando a unidade ou a homogeneidade literária, vistas por ele como limitação. Sua tese, polêmica na época, parte do pressuposto de que a literatura brasileira está em devir, sendo no momento um braço da portuguesa, que por sua vez é atrelada à espanhola, e que remete às literaturas árabe, indiana, nórdica, e assim sucessivamente, formando um grande mosaico universal. Para Azevedo, a riqueza das "letras pátrias" pode ser comparada a uma "praia tão derramada de pérolas e corais pelas marés que aí haviam passado no seu fluxo, das civilizações púnicas, grecoromanas, góticas e arábicas"; ainda segundo o poeta "a literatura de um povo era influída, como um líquido noutro, em sua civilização". ${ }^{197}$ A imagem das águas oceânicas em movimento conduz a sua poética ao ideal de uma literatura universal, distanciada da homogeneidade e da monotonia, enxergadas por ele na adequação aos modelos canônicos da literatura indianista, que contrastam com o impulso pela variedade de fontes, temas e formas almejadas em sua poética.

Conforme Cilaine Alves expõe, a estratégia argumentativa de Azevedo no ensaio citado frustra a proposição nacionalista da busca de uma origem primeira, e dilui as fronteiras entre os diferentes sistemas literários, ao fazer uso intenso das digressões responsáveis por evocar múltiplas fontes. O texto se torna pesadamente prolixo e impede que um foco principal se estabeleça. O emprego da forma irregular serve aqui

${ }^{196}$ AZEVEDO, Álvares de. "Literatura e civilização em Portugal". In: Obra completa, BUENO, Alexei (org.) Rio de Janeiro: Nova Aguilar, 2000, p.720.

${ }^{197}$ AZEVEDO Álvares de, 2000, p. 712. 
para reforçar o ponto de vista de Azevedo, sobre a impossibilidade de uma identidade literária nacional, em um país que vivenciara há pouco tempo a sua Independência. ${ }^{198}$

O tema da defesa da multiplicidade na poesia do autor estudado, Antonio Candido lembra, está presente também na "Invocação" a Byron, na abertura da segunda parte de $O$ conde Lopo. A passagem, Candido destaca, tem o subtítulo "Variações em todas as cordas", que poderia servir como indicação da "teoria estética" de Álvares de Azevedo, pois assume a variação de estilos e temas como fundamento de seu "programa literário". ${ }^{199}$ Ali, Azevedo invoca a musa byroniana e os heróis errantes criados pelo poeta inglês, como Mazeppa ao "galope do corcel da Ucrânia", o "Lara Vagabundo", o Manfred sonhando "nas terras ermas", e o "Pálido Dom João", peregrino do desejo. No capítulo anterior desta dissertação, fora comentado sobre a importância da figura de Childe Harold na composição do foco do narrador-cavaleiro-andante e a sua ligação com o gênero poema miscelânea. João Adolfo Hansen discute a sistematização dos procedimentos relacionados à mistura estilística do gênero "poema miscelânea", com base nas obras de Lord Byron, como Beppo e Childe Harold. Os longos poemas byronianos buscam uma forma capaz de abarcar gêneros, estilos, temas e vozes diversos, embaralhando os registros elevados e heroicos aos baixos e cômicos. Essa alternância poética comportada no uso da mescla estilística dá vazão às oscilações de humor do narrador "gênio", misto de "negatividade, ideal e errância", 200

A binomia alvaresiana, fundada na ironia, pressupõe a oscilação do duplo registro estilístico, dividido entre a elevação e o rebaixamento de perspectivas opostas em seu discurso, essencialmente sublime. O "misto poético", movido pela autorreflexão infinita, "impede que a consciência do leitor se fixe em qualquer objeto particular figurado". ${ }^{201}$ Isso gera a indeterminação do sentido, sempre duplo e ambíguo, uma vez que a forma, parcial e provisória, pode revelar apenas o fragmento de um sentido total aludido e jamais alcançado.

198 CUNHA, Cilaine Alves. Entusiasmo indianista e ironia byroniana, Tese de doutorado. FFLCH/USP. São Paulo, 2000, pp. 185-223.

199 CANDIDO, Antonio. "Introdução", in: AZEVEDO, Álvares de. Os melhores poemas de Álvares de Azevedo, 1994, p.14. A ideia de "variações em todas as cordas" aparece de certo modo na seguinte afirmação de Friedrich Schlegel: "Um homem verdadeiramente livre e culto teria de poder se afinar a seu bel-prazer ao tom filosófico ou filológico, crítico ou poético, histórico ou retórico, antigo ou moderno, de modo inteiramente arbitrário, como se afina um instrumento, em qualquer tempo e em qualquer escala". $C f$. SCHLEGEL, Friedrich. $O$ dialeto dos fragmentos. Trad. Márcio Suzuki. São Paulo: Editora Iluminuras, 1997, p. 29.

${ }^{200}$ HANSEN, João Adolfo. "Forma romântica e psicologismo crítico". In: ALVES, Cilaine. O belo e o disforme: Álvares de Azevedo e a ironia romântica, 1998, pp. 12-13.

201 Idem, idem, p. 13. 
João Adolfo Hansen lembra que, durante o romantismo, "a forma expressa a reflexão de sua própria essência”. A prática poética idealista então em voga se divide entre a contemplação melancólica do "Todo ausente", e a negação do finito. Cindido pela autorreflexão infinita, o poema passa a ser a expressão do "autodilaceramento como insuficiência artística aquém da bela síntese ideal". A consciência irônica da forma romântica oscila entre a clara percepção dos limites e a aspiração ao infinito inacessível, expressando a lembrança permanente de que "a forma poética não é meio para o conteúdo, mas expressão negativa dos limites da consciência aquém do Todo.” A dualidade contraditória, inerente ao estilo romântico, repercute na estrutura de suas personagens, que também expressam "nas antíteses a unidade utópica e apenas aludida do Conteúdo como todo além da fragmentação prática". ${ }^{202}$ Nessa perspectiva, a escrita do narrador alvaresiano é sempre a "expressão dupla desse Todo ausente", e se funda na teorização da poesia como "revelação fragmentária ou binômica do ideal". ${ }^{203}$ Os limites do finito e do condicionado, expressos no poema particular, são ocultados sob um efeito de informalidade poética, que simula a "liberdade de expressão e a ausência de regras". 204

A distribuição mesclada de assuntos nos diferentes registros estilísticos produz a indeterminação e a incompletude da forma. Recorrendo a esse procedimento, o poeta "produz a ficção retórica da falta de retórica do que é dito, compondo-a como estrutura a ser percebida como ausência de estrutura" ${ }^{205}$, e cria a impressão de invisibilidade do artifício poético. A poesia de cunho idealista busca a subjetivação da elocução, faz a critica do finito e cultiva o "sentimento do indefinido", ao adotar deliberadamente técnicas que produzem a sensação de informalismo e de "ausência aparente de critérios para o julgamento estético". ${ }^{206}$ A invisibilidade desse efeito, continua João Adolfo Hansen, tanto era mais eficaz no século XIX, "se as obras apareciam como um escombro, um resto incendiado do contato fulminante da alma do poeta com a indeterminação". ${ }^{207}$ A forma nega a matéria finita, e a deixa "para trás no movimento da autorreflexão", processo no qual exterioriza os fragmentos do indizível e do Todo. A concepção de linguagem romântica mascara suas bases reflexivas ao inserir signos "fáticos e enfáticos", responsáveis por acentuar a intensidade do patético na enunciação.

\footnotetext{
202 Idem, idem, p. 14.

203 Idem, idem, p. 17.

204 Idem,idem, p. 20.

205 Idem ,idem, p. 15.

206 Idem, idem,p. 20.

207 Idem, idem, pp.21-22.
} 
Aspectos referentes à argumentação, encarados como marcas do artifício poético, são neutralizados.

As digressões que estruturam o discurso descontínuo de Álvares de Azevedo são marcas da impossibilidade de abarcar a totalidade do conhecimento absoluto do mundo múltiplo, nos estreitos limites da forma. O conteúdo múltiplo da realidade se coloca em conflito com esta última, e busca novas formas de expressão capazes de abarcar aquilo que é, em último grau, inexprimível. A forma, saturada pela multiplicidade das verdades e diferentes perspectivas sobre o mundo, implode e se estilhaça. No esforço de abarcar essas múltiplas direções, a consciência do artista se dispersa em todas as direções possíveis, tal como as linhas indefinidas e descontínuas do fumo pelo ar.

\section{Desproporção e truncamento: o "atropelar de mil ideias"}

A movimentação oscilante da fumaça, como elemento análogo ao andamento sinuoso e vago do discurso do narrador de $O$ poema do frade, pode ser especialmente discutida em uma sequência de estrofes presentes no Canto Segundo; nela, é possível observar a tendência do narrador em fugir da ação objetiva das personagens, ao truncála todo momento com intromissões reflexivas, que favorecem o desdobramento de suas digressões e devaneios. De certa maneira, pode-se dizer que esta característica do narrador é amplificada no texto analisado abaixo, uma vez que a personagem Jônatas mostra-se também inclinada às divagações.

O canto se abre de forma bastante vaga, sem relação de continuidade direta com o desfecho do canto anterior. A figura do herói Jônatas, que vinha sendo apresentada no Canto Primeiro, não é retomada, tampouco são encadeados eventos pertinentes a uma epopeia, conforme fora sinalizado no desfecho do canto de abertura. O que se vê é uma longa e vaga meditação sobre o amor por uma prostituta, esboçada até a estrofe IX. Só depois disso, inicia-se a narração abrupta das andanças noturnas do libertino Jônatas pelas ruas da cidade. Ainda assim, a ação não flui, interrompida a todo momento pelas intrusões do narrador, que tece considerações formais e suposições sobre a atribulação psicológica da personagem naquela cena. Há uma evidente desproporção entre o espaço exíguo ocupado pela ação da personagem no trecho, e as longas reflexões do enunciador. As duas estrofes abaixo exemplificam o modo tortuoso como a ação se desenvolve: 
$\mathrm{X}$

Era alta noite. Jônatas saíra -

Precisava frescor - enfebrecida

A fronte na descrença sucumbira.

Maldizia no tédio a negra vida,

Até as ilusões que ele sentira!

Curvava a testa mórbida, abatida,

Sempre sedento, sempre libertino,

Blasfemando do amor e do destino!

\section{XI}

Ele viu — não foi sonho - era sentada

À sombra no balcão de uma janela

Angélica mulher: luz embaçada

De um estrelado céu nas faces dela

Branqueava-lhe a face descorada

E os seios níveos que o cetim revela...

Além imagens vãs! a oitava finda:

Só vos posso dizer, que ela era linda. ${ }^{208}$

As estrofes são permeadas de travessões, vírgulas, exclamações e reticências, sinais gráficos que reforçam a representação da personagem febril e agitada em seu tumulto interior. A segunda oitava citada é mais fluente, pois desloca o foco de atenção da interioridade turbulenta de Jônatas para a visão da linda moça, que o arrebata. A grandeza da beleza da "angélica mulher" é sugerida pelo uso das reticências, no sexto verso da oitava XI, seguida pela expressão “Além imagens vãs!". No entanto, a narração da cena é interrompida no penúltimo verso, sob o pretexto de que "a oitava finda”. Diante da limitação da forma estrófica, o enunciador resume a descrição da figura feminina com o lacônico comentário: "Só posso vos dizer, que ela era linda". O uso da vírgula quebra o último verso, e reforça a dissonância.

Apesar do destaque dado a essa pausa no texto, segue-se com a narração na oitava seguinte, focada novamente na cena de Jônatas, deslumbrado ao contemplar a linda moça. O narrador procura reproduzir as impressões do rapaz, que, assim como ele, se mostra bastante inclinado às divagações:

\section{XII}

Não tão aérea Jocelyn passando

Vira Laurence pálida, abatida.

Nem tão bela a sentira suspirando

Abafando a saudade emurchecida!

Com a face na mão - muda, cismando

Tão branca era a gentil desconhecida!

Nos cabelos a noite recendia!

Era tão bela assim... e ela dormia!

${ }^{208}$ AZEVEDO, Álvares de. “O poema do frade”, in: 2002, Canto Segundo, p. 319. 
XIII

Esperavam alguém? A porta aberta

Bem essa ideia despertar podia.

Entrou. Do lampião a luz incerta

Entre as sombras alentos exauria.

Ele subiu - a sala era deserta.

Passando p'la cabeça a mão - sentia

Não sei que atropelar de mil ideias,

Que frio ignoto a comprimir-lhe as veias.

XIV

E que cisma! que insano devaneio

Na mente exausta repassar-lhe vinha!

Do vicio e do bordel tinha receio?

Volvia à fé que desbotado tinha?

Doía-lhe ao coração de um torpe enleio

- Como no lodo as asas a andorinha -

Do leito profanado às sombras densas

Uma per uma ter manchado as crenças?

\section{XV}

Não! revoava-lhe um outro pensamento,

Mais duro e positivo e verdadeiro:

A ideia do devasso macilento

Lhe doía no cérebro altaneiro...

Pensava que amanhã o seu sustento

Findaria por míngua de dinheiro...

Poucas moedas viu na bolsa finda...

Porém bastantes para amar ainda! ${ }^{209}$

Percebe-se a intercalação dos movimentos físicos da personagem, que avança no espaço deserto e pouco iluminado, com os movimentos de seu pensamento, vacilando diante das lembranças de seu passado libertino, evocadas pela situação presente, e o receio pela decisão de suicídio tomada. Novamente, o emprego de sinais de interrogação, exclamação, travessão e reticências reproduz o "atropelar de mil ideias" que assalta o garoto. Antes mesmo que o quarto vazio, a sua mente torna-se o palco da cena; as idas e vindas da reflexão evidenciam o dilema da personagem, dividida entre a vida e a morte, a fé e a descrença. Jônatas divaga sobre as diferentes possibilidades de rumo para seu futuro, mas o enfático "Não!", na estrofe XV, indica a sua resolução final de matar-se. Ainda assim, a personagem continua a meditar prolixamente, até a estância XXI. Só então Jônatas acaricia levemente a moça a quem contemplava, e murmura o nome "Consuelo".

Durante o Canto Segundo, os possíveis diálogos trocados entre as personagens não aparecem transcritos no texto. Tudo é sugerido de maneira indireta, intermediado pelo narrador, diferente do que ocorre no modelo dramático, no qual os diálogos e as

209 Idem, idem, Canto Segundo, p. 320. 
ações movimentam o enredo, como se este fluísse por si mesmo, gerando a ilusão de realidade. Na maioria das vezes em que as personagens surgem no poema, ora estão dormindo, sonhando, cismando, contemplando algo ou mesmo tomadas por completo delírio. Na primeira das estrofes reproduzidas logo abaixo, a ação desenvolve-se de modo fluente até a antepenúltima estrofe, que é sucedida por duas linhas pontilhadas, responsáveis por marcar mais uma pausa e nova intrusão do narrador, que não mostra diretamente o ato sexual das personagens, mas o metaforiza com imagens da natureza, como "ao sol do verão romã partida", "na brisa um hálito fremente", "a lua celeste e vagarosa/ Num leito derramar sua luz saudosa":

\section{XXII}

Consuelo despertou (era o seu nome)

E tão doce volveu os olhos santos,

Que ele sentiu que a febre que consome

Humano imaginar em sonhos tantos,

Que delira coroas e renome,

Desmaia da mulher ante os encantos,

Quando entreabre-se o peito ao ar da vida

- Como ao sol do verão romã partida!

\section{XXIII}

Do mais eu nada sei. Senti somente

À noite duas almas suspirando:

Ouvi na brisa um hálito fremente,

Qual de um seio em prazer se dilatando:

Ouvi a jura efêmera, demente

Passar como um suspiro desmaiando,

Vi a lua celeste e vagarosa

Num leito derramar a luz saudosa! $!^{210}$

Como foi comentado acima, a primeira das oitavas acima está completa, mas é acompanhada de duas linhas pontilhadas extras, acopladas a seu final. Na iminência de contar a relação sexual de Jônatas e Consuelo, o narrador prefere ser sugestivo e manter um tom de mistério. Diante disso, as linhas pontilhadas podem ser interpretadas de múltiplas formas: podem ser uma pausa decorosa, ou mesmo um vácuo, que o leitor deve preencher conforme lhe sugira a própria imaginação. Até porque, logo a seguir, o narrador se limita a dizer, obliquamente, que nada sabe do ocorrido, deixando a lacuna livre para o leitor completá-la a seu modo. Há uma profusão de imagens nas estrofes seguintes, nas quais mesclam-se referências místicas e eróticas, como "místico beijo", "voo estremecido", "túmido gemido":

210 Idem, idem, Canto Segundo, pp. 322-323. 
$\mathrm{XXV}$

Místico beijo se escoou sentido

Como de pombos cândidos que adejam

O sussurro de voo estremecido!

E sobre os peitos que febris latejam

Sufocava-se o túmido gemido

Como as donzelas que de amor se beijam!

Almas cheias de vida! pareciam

Que as vidas numa vida confundiam! $!^{211}$

A oitava seguinte, de número XXVI, está completa, contudo possui uma nona linha extra, que destoa do padrão do conjunto estrófico em oitavas presente no Canto Segundo. A linha pontilhada em questão interrompe a atmosfera mística e sensual, sugerida nas estrofes precedentes, para incluir considerações de ordem formal, presentes nas duas estrofes de fechamento do canto. Nelas, discute-se a questão do decoro na poesia, além de condensarem-se uma série de informações decisivas sobre a estrutura deste canto. O narrador elenca motivos para justificar a interrupção da cena de enlace sexual de Jônatas e Consuelo:

\section{XXVII}

Se quereis, meu leitor, saber agora

$\mathrm{O}$ que a isto seguiu-se - eu não o digo,

Porque senão minha leitora cora:

E obro nisto por certo qual amigo:

E também porque, a musa me descora

Quando nestas visões a ideia sigo.

Demais findou-se de licor meu copo,

E a seco poetar jamais eu topo!

\section{XXVIII}

Importa-vos porém saber que a cena Que descrevi primeiro neste Canto

Veio desta ao depois. - A Madalena

Por quem ali eu desatei em pranto

Foi a presente criatura amena,

Que, certo, é digna que eu fizesse tanto!

E pois que a meus heróis Morfeu namora

Também cansado vou dormir agora! $!^{12}$

$\mathrm{Na}$ primeira destas estrofes, o narrador irônico afirma que não desenvolverá ainda mais a narração do encontro íntimo de Jônatas e Consuelo, construído com tanta prolixidade até ali, para não constranger suas leitoras. O que se vê é a frustração do clímax do Canto Segundo. Ele também alega recusar-se a poetar de copo vazio, e por

211 Idem, idem, p. 323.
212 Idem, idem, Canto Segundo, p. 323-324. 
ser acometido igualmente pelo sono como suas personagens ${ }^{213}$, incorporando circunstâncias exteriores (o copo vazio) e interiores ao texto (o sono das personagens o contamina), ambas como determinantes de sua construção.

Para desnortear ainda mais seu leitor, o narrador subverte toda a estrutura do Canto Segundo, ao revelar que a linearidade das estrofes não é aquela designada segundo a numeração das estrofes apresentada. Ele só então explica que a longa meditação sobre a trágica prostituta, desenvolvida nas nove primeiras estrofes, na verdade devem ser lidas não como a abertura do canto, mas como o seu fechamento. Caso o Canto Segundo fosse iniciado a partir do conteúdo expresso na estrofe $\mathrm{X}$ em diante, haveria uma continuidade direta entre os cantos primeiro e segundo, pois o foco do discurso permaneceria em Jônatas, uma vez que a personagem é apresentada no Canto Primeiro, e a estrofe $\mathrm{X}$ do Canto Segundo daria continuidade à narração, ao focar as andanças do herói pela cidade e o seu encontro com a prostituta Consuelo.

Ao adotar esse encadeamento mais linear, em vez de inserir a reflexão sobre a condição trágica de Consuelo no início do Canto Segundo, ficaria evidente a identificação da moça como objeto da meditação desenvolvida nas primeiras estrofes deste canto, pois a jovem não havia sido sequer mencionada no Canto Primeiro. Isso eliminaria o suspense diante da imagem indeterminada e misteriosa da prostituta, desenvolvida nas nove primeiras estrofes do Canto Segundo.

Ao optar pelo embaralhamento dos assuntos, e comprometer a linearidade da narração, o enunciador de $O$ poema do frade deixa patente o seu desejo de favorecer a confusão e a indefinição, em detrimento da clareza do texto. O encadeamento tortuoso do discurso no Canto Segundo não parece ser causado por ausência de revisão, mas antes resultar de um planejamento. As considerações contidas nas últimas estrofes revelam mais uma vez o riso satisfeito do narrador, diante da dificuldade produzida nesta abertura digressiva, vaga e caótica, à maneira daquela encontrada nas oitavas de abertura do Canto Primeiro, discutidas no primeiro capítulo desta dissertação.

\footnotetext{
213 Segundo Curtius, o argumento da fadiga é uma tópica do remate na tradição clássica. A coincidência entre encerramento do texto e a alegação de que a musa está exausta é um topos medieval. Também coincide o desfecho do texto com o tema do cair da noite, momento em que o poeta argumenta ter de encerrá-lo, sob o pretexto de ser "incômodo escrever na treva", cf. CURTIUS, 1996, pp. 133-136. No entanto, na tradição clássica, esse topos simula seriedade, e quer persuadir o leitor. Dessa maneira, se afasta do tom de pilhéria e da arbitrariedade evidente no encerramento do Canto Segundo de O poema do frade.
} 


\title{
Fantasia e embriaguez
}

Ao encadear metáforas em longas cadeias digressivas, frequentemente o narrador de $O$ poema do frade simula espanto com a direção imprevisível assumida por seus versos:

\author{
Onde vou? onde vou? Oh! quão diversos \\ Do meu trilho meus passos desvariam! \\ Onde correis, meus desgraçados versos! \\ A tempo os açaimei! onde corriam! \\ No fantástico pó que eles pisavam \\ Entre nuvens ardentes galopavam! ${ }^{214}$
}

Os passos do poeta "desvariam" e fogem de seu "trilho", ainda que ele se empenhe em controlá-los. A ideia do galope entre "nuvens ardentes" no "fantástico pó" gera a comparação, ao longo do poema, da imaginação poética a um cavalo de difícil controle, do qual é preciso tomar as rédeas. É recorrente a vinculação, no poema, entre o exagero do estilo extravagante de escrita do narrador e a fantasia criadora.

\footnotetext{
Escutai-me, leitor, a minha história, É fantasia sim, porém amei-a.

Sonhei-a em sua palidez marmórea

Como a ninfa que volve-se na areia

Co'os lindos seios nus... Não sonho glória;

Escrevi porque a alma tinha cheia

- Numa insônia que o spleen entristecia -

De vibrações convulsas de ironia! $!^{215}$
}

Ainda que a história a ser contada seja "fantasia", isto é, produto da imaginação, do sonho, o narrador afirma amá-la verdadeiramente. O poema é encarado, no trecho, não como um produto destinado ao reconhecimento e à "glória" social perante o público, mas como uma espécie de necessidade vital espontânea, um transbordamento da alma "cheia" de tristeza e convulsa ironia. O poeta procura revestir a sua criação da aparência de natureza, incondicionada por elementos externos ao emergir poderosamente de sua imaginação, tal como um vulcão ou uma tempestade violenta. No trecho abaixo, já mencionado no primeiro capítulo desta dissertação, o narrador se insurge contra o leitor, este ainda apegado à recusa neoclássica contra a fantasia e em favor da objetividade da crônica histórica:

214 AZEVEDO, Álvares de. “O poema do frade”, in: 2002, Canto Terceiro, estr. LXVI, p. 338.
215 Idem, idem, Cf. estr. XIV do Canto Primeiro, p. 310. 


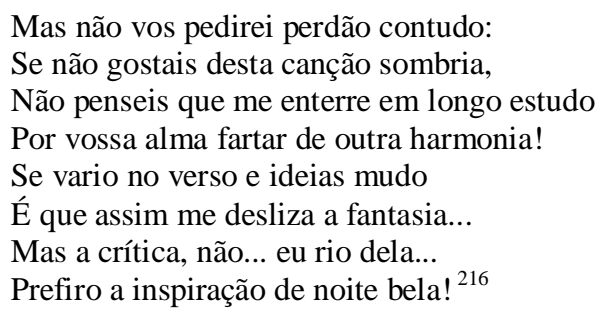

A fantasia é apresentada no trecho acima como fundamento do estilo mutante do frade-poeta, que varia livremente formas e assuntos em sua escrita, ao sabor de seu humor oscilante. Sua "canção sombria" "desliza" ao sabor da "fantasia", e diverge de uma "outra harmonia", associada ao "longo estudo". Em outras palavras, o narrador defende uma poesia obscura e subjetiva, rebelde em relação ao código objetivo e mimético da poesia neoclássica, fundamentado na rigorosa observação de normas fixas e bem definidas, consagradas pela autoridade da tradição. Esta é vinculada a uma noção específica de crítica externa à poesia, que fornece normas rígidas e invariáveis às quais o artista deve se adequar. Tal concepção é objeto de riso do narrador, que diz preferir a inspiração circunstancial de uma "noite bela". O poeta romântico não está isento de regras, no entanto, as assimila e subjetiviza a cada composição diferente.

Antonio Candido comenta a aversão, nutrida pelos primeiros poetas indianistas, em relação à exploração estética de "aspectos extremados", produtores, segundo esses autores, de uma poesia "falsa", "anormal" e "exagerada", típica do "romantismo monstruoso de nossos dias". ${ }^{217}$ Os excessos e extravagâncias de uma poesia romântica pautada pela fantasia distanciavam-se do comedimento buscado pelos primeiros indianistas, grupo que, nas palavras de Antonio Candido, "conduziu o romantismo inicial [no Brasil] para o conformismo, o decoro, a aceitação pública". Nas mãos deles, o romantismo se tornou uma estética oficial, prevista e assimilada como parte da reforma política nacionalista. O chamado romantismo oficial se caracteriza por uma literatura ordenada, moderada e decorosa do ponto de vista moral. Percebe-se o desejo de conciliação dos valores da tradição neoclássica com a nova estética, que fez desses românticos brasileiros uma "geração vacilante" entre a herança neoclássica e a estética romântica, como bem define Antonio Candido.

\footnotetext{
${ }^{216}$ Idem, idem, trecho da oitava XV do mesmo canto.

${ }^{217}$ CANDIDO, Antonio. "Geração vacilante", in: Formação da literatura brasileira: momentos decisivos. Rio de Janeiro / Belo Horizonte: Itatiaia, 1993, v.2, p. 42.
} 
Ivan Teixeira explica que a fantasia foi enxergada no século XVIII como uma das causas para a desproporção resultante da "mistura de elementos díspares". ${ }^{218}$ A mistura de gêneros era desaconselhada pela tradição horaciana vigente, preceito encontrado já na primeira lição de sua Arte Poética, no famoso exemplo da imagem monstruosa da "mulher com pescoço de cavalo, penas de ave e cauda de peixe". O uso exagerado e reduplicado de "metáfora sobre metáfora", próprio do fantástico, se distanciava do ideal de clareza, ordem, simplicidade e moderação, alcançado na prática mais denotativa da linguagem recomendada pela Ilustração. Segundo essa orientação artística, "o hibridismo, a incongruência e o fantástico são aptos para figurar a falta de unidade de tipos cômicos, viciosos ou loucos" excelência da verossimilhança e do decoro". 220

Mario Praz aponta o vínculo profundo entre a noção de "fantasia" e as origens do termo "romantismo". Conforme ele explica, inicialmente o termo "romântico" designava produções literárias de traços "cavalheirescos e pastorais", nas quais se destacavam o pitoresco, o quimérico e o fabuloso — sinônimos de "romanesco". No decorrer do século XVIII, diante da tendência racionalista predominante na literatura europeia, o romanesco, com sua "índole fantástica", é muitas vezes associado às noções de falsidade, irrealidade e irracionalidade. Por isso, o termo "romântico", ainda segundo Praz, aparece como uma "qualificação pejorativa”, tal como "gótico" ou "barroco":

A vagueza indicada por romântico nesse estado de seu desenvolvimento resulta evidentemente pelas outras palavras das quais ela se encontra normalmente acompanhada: isto é, quimérico, ridículo, inatural, bombástico. Lê-se sobre "poemas românticos e infantis", sobre "românticos absurdos e ficções incríveis", e assim vai. A verdade da natureza é oposta à falsidade dos romances. Tudo o que o que parecia produto de desregulada fantasia era chamado de romântico. ${ }^{221}$

\footnotetext{
218 TEIXEIRA, Ivan. Mecenato Pombalino e Poesia Neoclássica. São Paulo: Editora da Universidade de São Paulo, 1999, p.143. Em nota, Ernst Robert Curtius fala de um documento de 1344, de Álvaro Pelayo, na qual aparece esta concepção do termo "romântico": "E por isso prescreveu o Senhor ... que se lessem ou ouvissem as Sagradas Escrituras, e não livros românticos, que contém fábulas, mentiras e deleites da carne...”. Cf. CURTIUS, Ernst Robert. Literatura Europeia e Idade Média Latina. São Paulo: Hucitec/Edusp, 1996, p. 65.

219 TEIXEIRA, 1999, p. 147.

${ }^{220}$ Idem, idem, p. 150.

${ }^{221}$ PRAZ, Mário. A carne, a morte e o diabo na literatura romântica. Campinas: UNICAMP, 1996, p.32. Segundo explica Paolo D’Angelo, “o grupo romântico de Jena estava perfeitamente consciente de sua especificidade; mas convém precisar neste ponto que este nunca se autodenominou romântico. $\mathrm{O}$ termo 'romântico' é usado por todos os colaboradores do Athenaeum não como autodesignação de escola, mas como nome de uma poesia que, por um lado, se identifica com um referente histórico preciso, a poesia cristã medieval-renascentista, e, por outro, é a autêntica poesia ainda por produzir”, in: D'ANGELO, Paolo. A estética do romantismo. Tradução Isabel Teresa Santos. Lisboa: Estampa, 1998, p.22.
} 
Ao longo do século XVIII, a fantasia foi gradativamente ganhando terreno nas artes, como é possível conferir nas teorias de Rousseau, Diderot, Novalis e Friedrich Schlegel, por exemplo. Nelas, é possível observar o processo de separação do belo e da moral, e a valorização do "excêntrico e do monstruoso" como índice de originalidade poética. $^{222}$ A fantasia passa a ser encarada como valor poético, sinônimo de desprendimento dos critérios objetivos e externos, ao amparar uma poesia que propõe medir-se por si mesma, tornando-se o emblema da liberdade criativa ilimitada. A fantasia deixa de ser vista como faculdade inferior, e ganha a dignidade de atividade intelectual, segundo a qual se reconhece que, tal como as fórmulas matemáticas e as curvas melódicas da música, seus livres movimentos abstratos são capazes de formar um mundo autônomo, jogando infinitamente consigo mesmo, ao propor novas e variadas conexões e combinações do pensamento. ${ }^{223}$

Conforme explica Giovanni Lombardo, a fantasia, na perspectiva do estilo sublime, passa a ser encarada como uma faculdade própria da "grandeza intelectual". ${ }^{24}$ Ela produz a ilusão de concretizar visualmente aquilo que é declamado ao público ou escrito no papel, como se embaralhasse e fundisse os diferentes sentidos físicos. Suas imagens mentais poderosas são alimentadas pelo entusiasmo e a paixão, proporcionando a mescla inesperada dos "clarões da phantasia por entre os rigores da lógica". A fantasia é astúcia ocultada, arte encoberta com arte, um fundamento do estilo sublime que permite "usar a figura sem a fazer aparecer como tal". Em outras palavras, trata-se de um "ímpeto emotivo" que "nos dê a impressão de iludir o mecanismo reflexo da linguagem enquanto mediação lógica e ao mesmo tempo estilística", o que faz com que o artifício (techne) e a elaboração intelectual, sejam ocultados. ${ }^{225}$

A aparência da poesia que se desenvolve como natureza espontânea, sem demonstrar submeter-se ao trabalho técnico e intelectual do artista, não raramente associa o processo da criação artística ao estado de embriaguez. Em O poema do frade, a fantasia criadora se vincula à ideia de transbordamento violento da alma inspirada:

\footnotetext{
Ah! que na lira se arrebente a corda

Quando profana mão os sons lhe acorda!

E o pobre sonhador a fantasia

O sonho que ama e beija noite e dia
}

${ }^{222}$ FRIEDRICH, Hugo. Estrutura da lírica moderna: da metade do século XIX a meados do século XX. São Paulo: Duas Cidades, 1978, p.29.

${ }^{223}$ Idem, idem, p 58.

224 LOMBARDO, Giovanni, 2002, p. 191.

225 Idem, idem, p. 192. 
Não saiba traduzir, quando transborda

Seu peito dos alentos da harmonia! $!^{226}$

O estado de arrebatamento causado pelo álcool faz lembrar o tema do transe dionisíaco, aproximando o humano do divino, conforme a ideia de elevação sobrenatural, prevista pelo estilo sublime. O contato com a "profana mão", na estrofe citada acima, faz com que "na lira se arrebente a corda", uma vez que a poesia concebida na perspectiva do sublime aproxima a criação estética à ideia do gênesis divino. $^{227}$ O "pobre sonhador", mero humano, volta seus olhos ao sonho absoluto e infinito, porém, não sabe "traduzir, quando transborda/ Seu peito dos alentos da harmonia". A linguagem humana não dá conta de representar a totalidade da realidade, e se depara com elementos que roçam o indizível, o intraduzível, situados para além das faculdades humanas de entendimento. Por isso, sua expressão será sempre alusiva, aproximativa, desdobrando-se em uma longa cadeia reflexiva que sugere o esforço interminável de formulação linguística do poeta rumo ao infinito. No Canto Primeiro de O poema do frade, uma longa digressão é iniciada, não por acaso, com a imagem de um cálice transbordante:

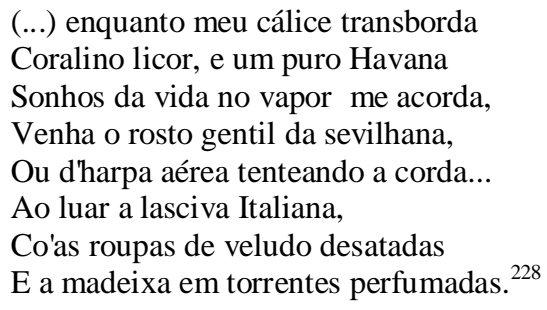

O cálice transborda, e coloca em movimento o devaneio ("sonhos da vida no vapor"), no qual se desdobram imagens como as da sensual sevilhana e da "lasciva Italiana", bem como da "harpa aérea", em uma atmosfera onírica de vapores e perfumes, que unifica a um só tempo a tendência à abstração do pensamento e o estímulo às sensações físicas. Esta digressão se desdobra da estrofe VII até a XIII do Canto Primeiro, repletas de imagens de orgias, perfumes, bailes e música, sempre associadas à embriaguez:

Trovas cheias de amor, que afogam beijos

\footnotetext{
${ }^{226}$ AZEVEDO, Álvares de. "O poema do frade", in: 2002. Canto Quinto, estr. XXX, p. 357.

${ }^{227}$ O tema do Fiat lux será tratado detalhadamente mais abaixo, ainda neste capítulo.

${ }^{228}$ AZEVEDO, Álvares de, 2002, Canto Primeiro, estr. VII, p. 308-309.
} 
E o afã a ondular os níveos seios,

O colar que na alvura se paleja,

E o olhar que enlanguesce nos enleios;

Vestes soltas ao fogo dos desejos,

E respirando os lábios devaneios

Amantes, e o Xerez em taças belas

E a embriaguez mais louca em meio delas! $!^{229}$

A ideia de transbordamento etílico é reforçada por expressões alusivas ao afogamento, e às trovas "cheias" de amor, o que contribui para a noção de plenitude e êxtase do prazer sensual, associado ao palor, ao enlanguescimento, ao "fogo dos desejos". Novamente, o estímulo aos sentidos desencadeia "devaneios", intensificados pelo estado de "embriaguez mais louca", gerado pelo vinho espanhol. Vale lembrar que o frade-narrador e a personagem Jônatas são ambos poetas libertinos, que recorrem à embriaguez como estado propício à inspiração: como já fora mencionado neste presente capítulo, o primeiro encerra o Canto Segundo ao alegar que findara-se o licor de seu copo, recusando-se a um "seco poetar". Jônatas também compõe sob a inspiração do vinho, capaz de desencadear "o fogo do gênio à flor dos lábios", conforme a oitava já mencionada no primeiro capítulo desta dissertação:

Só quando o fogo do licor corria

Da fronte no palor que avermelhava,

Com as convulsas mãos a taça enchia.

Então a inspiração lhe afervorava

E do vinho no eflúvio e nos ressábios

Vinha o fogo do gênio à flor dos lábios! $!^{230}$

Deve-se lembrar, ainda, que o Canto Primeiro de $O$ poema do frade é epigrafado com um trecho de D. Juan, de Byron, que versa sobre a embriaguez: Man being reasonable must get drunk/ The best of life is intoxication... ${ }^{231} \mathrm{Em}$ outros trechos, o narrador afirma que os versos de seu poema "cambaleiam" ou "cambeteiam" ao modo de um ébrio. A relação entre o poetar e o beber aparece também em outras composições da poética alvaresiana, como no poema "Boêmios", de Lira dos vinte anos: "Toma dez bebedeiras... são dez cantos./ Quanto a mim, tenho fé que a poesia/ Dorme dentro do vinho./ Os bons poetas/ Para ser imortais beberam muito". ${ }^{232}$ Em $O$ conde Lopo, por sua

\footnotetext{
${ }^{229}$ Idem, Estr. X, p. 309.

${ }^{230}$ Idem, Canto Primeiro, excerto da estr. XXVI, p. 313.

231 Idem, idem, p. 307.

232 Idem, "Boêmios", in: Poesias completas, 2002, pp. 164.
} 
vez, a embriaguez vem acompanhada do devaneio: "Em que mar d'ilusões não divagoulhe/ Em ébrios cantos que exalou sentida/ A sua transbordada fantasia!",233

De modo geral, pode-se afirmar que, em $O$ poema do frade, há uma clara relação entre a mente estimulada pela fantasia, e o consumo do entorpecente com a ideia de experimentação formal. Este vínculo é intensificado pela presença dos poetas libertinos na obra em questão, pois a experiência do corpo liga-se diretamente à sistemática quebra de paradigmas mentais. A inserção da epígrafe geral em $O$ poema do frade, retirada de Don Juan de Moliére, e aquela presente em seu Canto Primeiro, extraída do Don Juan de Lord Byron, deixam patente a intenção de Álvares de Azevedo de vincular o narrador e o herói de seu poema a uma tradição libertina na literatura.

Na lírica moderna, são frequentes as referências à bebida e outras drogas como vias artificiais para se alcançar o "sonhar acordado", estado no qual se torna possível conjugar, na criação poética, a fantasia e o intelecto, ou a imaginação e a reflexão. ${ }^{234}$ Em “A fabricação do vício", Henrique Carneiro trata, dentre outras questões, do tema das drogas na literatura oitocentista. A tentativa de reproduzir estados da mente menos acessíveis à razão, como o sonho, se torna possível na experiência com entorpecentes: “O experimentalismo das formas de consciência é aberto pelo uso controlado de drogas que permite desvendar o lado oculto e noturno do espírito". ${ }^{235}$ A tendência se faz notar especialmente na literatura de cunho fantástico, na pena de autores como De Quincey, Musset, Poe, Baudelaire e Gautier, exemplos citados por Carneiro. A publicação de Confissões de um comedor de ópio, de Thomas De Quincey, em 1821, inaugura "a teorização da relação entre a droga e a criação poética”. A produção de diferentes estados da consciência, propícios à auto-observação, visam o estudo de aspectos inerentes ao ser humano, mas ofuscados pelas luzes da normalidade:

É a atitude experimental diante da consciência que inaugura uma ciência cujo objeto é o próprio sujeito observador, e os instrumentos produtores de consciência alterada permitem ampliar a gama dos três estados básicos da consciência: vigília, sono e sonho. O ópio e o haxixe trazem o sonho para a vigília, confundem-nos num novo estado. Os anestésicos trazem o sono para a vigília, anulando-a quimicamente de uma forma tão absoluta que se tornaram possíveis as intervenções cirúrgicas indolores. ${ }^{236}$

\footnotetext{
233 Idem, O conde Lopo, 2002, p.441.

234 FRIEDRICH, Hugo, 1978, p. 190.

${ }^{235}$ CARNEIRO, Henrique Soares. "A fabricação do vício”, in: LPH-Revista de História, Departamento de História/ICHS/UFOP: Mariana-MG, nº 12, 2002, p. 20.

${ }^{236}$ Idem, idem.
} 
Trata-se de um debruçar-se sobre a própria interioridade, entendida como uma dimensão estendida para muito além dos domínios da razão. As drogas então provocam intencionalmente a produção de estados crepusculares e limítrofes, como se fossem uma espécie de lente de aumento, empregada na investigação da alma humana:

O tema do sonho já fazia parte do acervo poético do romantismo. Mas as drogas trazem novos dados experimentais sobre as noções tradicionais do fantástico. A natureza precisa das sensações, percepções, pensamentos e emoções produzidas pelas drogas se tornará assim não só um repertório literário ampliado de imagens e temas como uma via privilegiada do estudo científico da mente. Aos conceitos de alucinações, ilusões, visões, êxtases se juntará outro: o de loucura.

(...)

Numa época em que as especulações sobre a alma humana alcançavam uma expansão desvairante, com o mesmerismo, o espiritismo, o sonambulismo, os êxtases místicos e estéticos e a atmosfera onírica em geral fazendo parte da moda dos salões, o universo da loucura, do sonho e da droga encontravam o paralelo fácil: a loucura seria uma espécie de sonho acordado. A literatura refletindo esse clima renova também os temários tradicionais do gótico e amplia o gênero do fantástico com alusões diretas e indiretas à experiências farmacológicas (em Poe, Dumas, Flaubert, etc.).

Em Rimbaud essa busca deliberada e sistemática de alteração da consciência alcança um auge, com o "desregramento sistemático de todos os sentidos" para se obter a vidência. ${ }^{237}$

Como se vê, há uma relação entre o uso de entorpecentes e o cultivo da autorreflexão ao longo do século XIX, especialmente dedicada a relativizar os domínios da razão. Isso é estendido também no século XX com a escrita automática dentre os surrealistas, por exemplo.

\section{Variedade}

Ao longo deste capítulo, foi investigado o conjunto de metáforas que mimetizam o movimento da reflexão durante o processo de criação artística em $O$ poema do frade. Tais imagens costumam aparecer nesta obra sob a forma de navios que singram mares oscilantes; balões ou fumaças levados pelo vento instável; cavalos, vulcões e tempestades incontroláveis; ou ainda bebidas efervescentes. Estas metáforas permitem que o narrador instaure um discurso miscelânico e percorra os diferentes gêneros poéticos e assuntos, sem se fixar por muito tempo em nenhum deles. Observa-se a intercalação entre os gêneros, explorada de modo mais explícito nas estrofes de abertura

${ }^{237}$ Idem, pp. 21. 
do Canto Primeiro, como também a troca do modelo estrófico das oitavas, presente nos dois primeiros cantos, para o das sextilhas ${ }^{238}$, nos três cantos derradeiros de $O$ poema do frade. Essa substituição é anunciada na abertura do Canto Terceiro, quando se discute o princípio da "variedade", elevada a fundamento da extravagante poética do frade-poeta. Por meio dela, sua poética pessoal é aproximada do tema da gênese bíblica do universo, conforme se sugere, com humor, nas sextilhas abaixo:

\section{I}

De certo o Criador na tal semana Em que o mundo surgiu da escuridade E sobre o mundo a luz e a raça humana, Por lei estab'leceu a variedade. Teve muita razão: com todo o siso Atesto que mostrou muito juízo.

\section{II}

Bofé! que se uma atroz monotonia De um elemento a vida compusera, $\mathrm{O}$ homem até morrer bocejaria, E em morna estupidez se embrutecera. Quanto a mim, eu adoro a variedade E amo até no verão a tempestade!

\section{III}

Por gostar das galhofas da comédia $\mathrm{Da}$ alegria folgaz de Molière, Nem por isso me esqueço da tragédia Nem desamo o sombrio Miserere! Quando Hamleto findou sua agonia Do Falstaff bon-vivant vinha a folia!

\section{IV}

Acho belo o Oceano quando voo Pelo seu verde-mar num barco à vela. Porém odeio as aflições do enjoo E o vento do alto mar que me regela... Amo a lua no mar e o mar sem lua. Astarte vaporosa e Lolah nua.

\section{$\mathrm{V}$}

Como varia o vento - o céu, - o dia, Como estrelas e nuvens e mulheres Pela regra geral de todos seres, Minha lira também seus tons varia. E sem fazer esforço ou maravilha Troca as rimas da oitava p'la sextilha ${ }^{239}$

Acima, a variedade é contraposta à monotonia, causadora do tédio e do embrutecimento humano. A primeira é encarada como estímulo constante à imaginação,

${ }^{238}$ A hipótese interpretativa acerca do uso das sextilhas neste poema alvaresiano, porém, será investigada no próximo capitulo.

239 AZEVEDO, Álvares de. “O poema do frade”, Canto Terceiro, pp. 325-326. 
ao se valer de diversos temas, formas e estilos, avivados pelo contraste de imagens opostas: a tragédia e a comédia geram igualmente deleite; o oceano inspira a sensação de vastidão e liberdade, mas revela também a sua contraparte prosaica, por meio do enjoo e do frio importuno, sofridos pelos viajantes marítimos; a beleza é contemplada tanto em paisagens com a "lua no mar e o mar sem lua", e nas desiguais heroínas byronianas, como a etérea Astarte e a sensual Lolah.

O paralelo proposto entre a criação poética e a criação divina no Canto Terceiro é reforçado pela epígrafe extraída do poema "A Variedade", do poeta português Filinto Elísio: "Ó gracioso primor de natureza/ Atrativa, donosa variedade!/ Que tudo quanto tocas formoseias!". ${ }^{240}$ Trata-se de uma sátira à "ilusa doutorice", assentada nos "frutos do gosto" e do "lidado estudo". Nela, o eu poético visita o acervo monumental da biblioteca de Mafra ${ }^{241}$, onde invoca a Variedade; dotada de "leis fáceis, leis brandas, e agradáveis"; ela auxilia os poetas na luta contra o tedioso "Mundo informe, bruto, e feio”. Um trecho do poema de Filinto Elísio é bastante similar à estrofe II do Canto Terceiro de O poema do frade, reproduzida mais acima, pois apresenta a ideia de variedade contraposta ao tédio:

\footnotetext{
(...) Tudo o que agrada, Tem na mudança, tem no vário aspecto Fundamento aprazível. Sem a indústria Dessa tua inventora dextra, o Mundo De perdurável forma, sempre o mesmo, Cansaria o desejo, mais que a vista; E os homens morreriam definhados, Mais de enojo, que de árida doença.
}

O Tédio, inimigo da Variedade, caminha entre livros luxuosos, entregues à poeira da indiferença. ${ }^{242} \mathrm{O}$ sono acomete o poeta perante a edição da Henriqueida, cujo subtítulo designa um "poema heróico com advertências preliminares das regras da poesia épica, argumentos e notas":

\footnotetext{
240 Idem, 2002, p. 325. Em nota que acompanha o trecho, Péricles Eugênio da Silva Ramos aponta que a citação alvaresiana "difere levemente" do poema original de Filinto Elísio: "Ó gracioso primor da Natureza/Atrativa, donosa Variedade,/ Que quanto airosa tocas formoseias!". Cf. p.341.

241 É curioso notar que no Canto Terceiro de $O$ poema do frade, no qual o narrador caracteriza o seu estilo, tenha se valido da produção de um autor que foi um frade português.

242 Numa passagem do poema "A Variedade", "O Tédio/ Vem tomar posse da pecante obrinha,/ Toma-a nas frias mãos, a aperta, e gela;/ Com desbotado acesso chega a Obrinha/ Ao sôfrego Leitor, que a cada lauda,/ Depara co' a incivil sensaboria:/ Boceja, as mãos lhe afrouxam, cai em terra/ O Livro, ou o Papel desenxabido.", cf. ELÍSIO, Filinto. "A Variedade", in: Obras completas de Filinto Elísio. Organização de Francisco Manuel do Nascimento. Braga: APPACDM Distrital de Braga, 1998, vol. 5, pp.64-65.
} 
Com capa carmesim de térciopelo,

Brochas douradas de água, está acenando

Sem-saborão encosto, sobre a mesa

A Henriqueida, empolas assoprando,

Soporífero cofre de fastio,

Que entranha o sono, pelo cotovelo

De quem nele se encosta, e vai trepando

Pelo braço, pescoço, e face acima,

Té que entra nos retretes das pestanas. ${ }^{243}$

Junto ao volume em tripla camada de veludo vermelho, os "profundos volumaços/ de Lógica" e a Bíblia são alvos de pilhéria do eu poético, que contempla o semblante duro dos leitores da biblioteca de Mafra:

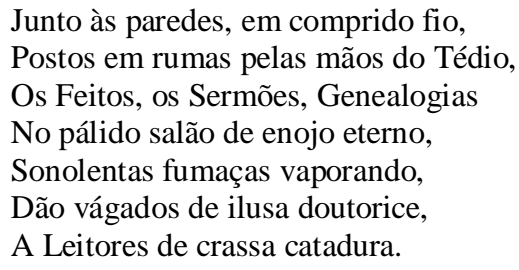

No final do poema, o eu poético de Filinto Elísio faz esforço para deter o impulso da pena, levada sempre além pela "Musa tagarela". Diante disso, a Variedade lança-lhe um olhar "jovial-malício", e o aconselha a arrematar o poema, "Se ao Tédio não quiser pagar tributo". A seguir, o poeta comenta alguns escritos impressos na cor verde, em nota acoplada ao poema: "As letras de ouro para inscrições são hoje tão corriqueiras já, que até nos rótulos das lóges dos Remendões as tenho visto. Justo era, que a Variedade as tomasse de outra cor, e que escolhesse a verde, que é cor alegre." O estilo juvenil e chistoso da Variedade contrasta a casmurrice reinante descrita no convento de Mafra. Vale observar que esse mesmo espírito brincalhão já era sugerido no subtítulo do poema de Filinto Elísio, no qual aparece a definição "garatuja poética". A palavra "garatuja" designa os primeiros rabiscos infantis, ou ainda uma caligrafia ruim ou apressada, de difícil leitura. Os versos seguintes desenvolvem esta noção: “Ah! vem, oh deleitosa Variedade:/ Acode-me c'o teu risonho enleio,/ E borrifa de agrado estas rabiscas!"

A inclinação de Filinto Elísio às formas extravagantes da garatuja combina-se ao fantástico e ao maravilhoso associados à sua poesia. O romantismo intensifica essa

${ }^{243}$ A Henriqueida (1741) é um poema heroico de Francisco Xavier de Menezes, o Conde de Ericeira, tradutor da Arte Poética de Boileau. Como se percebe, escritores vinculados a uma poética prescritiva de fundamento neoclássico são alvo de critica por parte de Filinto Elísio. 
tendência, ao cultivar o arabesco e o grotesco, interpretados como a exteriorização do fantástico. Por meio da fantasia é possível, inclusive, abordar o topos do poeta como criador divino, sugerido nas estrofes iniciais do Canto Terceiro de $O$ poema do frade. Por meio do conceito de criatividade vincula-se a criação poética com a força criadora do cosmo; essa noção era inexistente na Antiguidade, embora os poetas fossem considerados "homens divinos" e favoritos dos deuses, ao lado de "heróis, reis, arautos, sacerdotes e videntes". ${ }^{244}$ Ernst Robert Curtius explica que o conceito de criatividade é moderno, e valoriza o papel do poeta como agente da representação da realidade, em detrimento da mimesis tradicional. O poeta moderno ao projetar a sua percepção do mundo, toma como ponto de partida a sua interioridade, a partir da qual modela o mundo exterior. Daí, a postura egocêntrica do narrador-frade alvaresiano na primeira estrofe do Canto Terceiro, que inverte a hierarquia divina, e julga os atos de Deus, atestando que este teve "siso" ao estabelecer a lei da variedade: "Atesto que mostrou muito juízo".

Curtius assinala que Longino, no século III da era cristã, abalou o conceito de mimesis, ao propor uma ruptura entre poesia e retórica; ele supõe que a ousadia do pensamento e da emoção veemente é inata e pode ser educada pela técnica; porém, a arte não depende somente de técnica, pois nem sempre é "ensinável". Conforme Giovanni Lombardo assinala, por sua vez, em Longino a verdadeira poesia possui "vocação sobre-humana": sua "potência cósmica" excede as medidas da reprodução mimética escultórica, ou seja, vai além da percepção finita do real. ${ }^{245}$ Para alcançar a grandeza divina e sobrenatural, o poeta deve se elevar à grandeza do cosmo: deve anular a distância entre o gesto moral de sua paixão e a enunciação, de modo a tentar reproduzir a ilusão da "divina identidade da palavra e da ação". No episódio bíblico do Fiat Lux, existe uma coincidência ente a palavra e a criação, ou a simultaneidade entre a voz de Deus e o acontecimento nomeado. ${ }^{246}$

Em Longino, o estilo sublime provoca antes arrebatamento do que persuasão, vinculando-se à violência das paixões. A valorização da projeção dos afetos implica a valorização da figura do poeta: a literatura é, para Longino, o produto de um "nobre espírito". ${ }^{247}$ Lombardo afirma que "nas almas excelsas" existe um "desejo irresistível de

${ }^{244}$ CURTIUS, Ernest Robert. "Imitação e Criação", in Literatura Europeia e Idade Média Latina. São Paulo: Hucitec/Edusp, 1996, p. 485.

${ }^{245}$ LOMBARDO, Giovanni, 2002, p. 194.

${ }^{246}$ Idem, pp. 185-187.

${ }^{247}$ CURTIUS, 1996, p. 485. 
grandeza e daquilo que há de mais divino no homem". ${ }^{248}$ Diante da magnanimidade formal, as deformações violentas, desproporções e erros, tornam-se pequenos diante do conjunto sublime alcançado. Longino "deliberadamente recusa confundir ‘impecabilidade' com 'perfeição'. A grandeza nunca é 'correta”. ${ }^{249}$ Ou ainda, nas palavras de Giovanni Lombardo: "Os engenhos extraordinariamente grandes não são imaculados: porque, aspirando temerariamente aos vértices incorruptos, por vezes precipitam-se precisamente devido à arriscada prova em que estão empenhados". ${ }^{250}$ Nesta perspectiva, mais vale a grandeza com algumas imperfeições, do que uma “correção insípida e niveladora", ou a "irrepreensibilidade incapaz de golpes de asa". ${ }^{251}$ No estilo sublime teorizado por Longino, a essência da beleza poética não se reduz a "uma crítica aos erros. Os grandes autores não são isentos de erros, mas todos chegam à imortalidade". ${ }^{252}$

Conforme Curtius assinala, os poetas modernos encontraram na ideia de criatividade "a palavra redentora que sobreleva a Natureza e a arte e associa o poeta às potências cosmogônicas". 253 O logos, entendido enquanto "linguagem como racionalidade", pode desdobrar-se infinitamente, levando o homem "para além do próprio homem", excedendo os "limites de uma percepção finita do real" concebida segundo a reprodução mimética e escultórica da realidade. A linguagem sublime conecta o artista à natureza "enquanto potência cósmica" ${ }^{254}$ No romantismo, a noção de gênio vem acompanhada daquelas de "fantasia" e "imaginação"; o sublime é vinculado à ousadia do pensamento, ao arrebatamento da alma e concebe a forma de modo conflitivo; o belo, por outro lado, pressupõe a harmonia da proporção, e a serenidade da perfeição. O romantismo tende ao primeiro deles, e vale-se das formas fantásticas, como o arabesco e o grotesco. Este último abala a monotonia da beleza por ser uma manifestação do caráter heterogêneo da fantasia, capaz de realizar a "fusão irreal das

\footnotetext{
${ }^{248}$ LOMBARDO, Giovanni, 2002, p. 186.

${ }^{249}$ CURTIUS, 1996, p.486.

${ }^{250}$ LOMBARDO, Giovanni, 2002, p. 193.

${ }^{251}$ Idem, idem.

${ }^{252}$ CURTIUS, 1996, p.488.

${ }^{253}$ Idem, p. 484. Na mesma página, Curtius cita o texto "Oração", de Goethe, uma homenagem à catedral de Estrasburgo, na qual a palavra "garatuja" surge associada à força criadora do poeta, análoga às forças naturais e divinas: "Tu és viva, e não materiais reunidos e remendados. Diante de ti (...), como diante dos grandes pensamentos da criação, desperta na alma o que nela também é força criadora. Na poesia, ela balbucia, no papel agita linhas de garatujas em adoração ao criador...".

${ }^{254}$ LOMBARDO, Giovanni ,2002, p. 194.
} 
coisas mais díspares" ${ }^{255}$, conforme exige uma poética pautada pelo princípio miscelânico da "variedade".

\section{Linhagem digressiva}

A tendência ao discurso digressivo encontrada em $O$ poema do frade pode ser melhor compreendida ao se considerar toda uma tradição experimental, que põe em xeque a concepção de unidade formulada segundo a poética de tradição neoclássica. Na segunda metade do século XVIII, o escritor Laurence Sterne (1760-1767) levava às últimas consequências o seu "horror à linha reta", no romance $A$ vida e as opiniões do cavalheiro Tristram Shandy. Conforme José Paulo Paes assinala, Sterne assimilou o estilo dos poemas herói-cômicos e sua "digressão miscelânica", e recorreu à "imitação satírica da matéria heroica por via do tratamento, em linguagem elevada, de um tema trivial". ${ }^{256} \mathrm{Na}$ composição do romance citado, Sterne se vale amplamente de narrativas interpoladas e outros malabarismos formais, como o uso criativo de recursos tipográficos, a inclusão da dedicatória e prefácio no meio do livro, não na abertura; a falta intencional de um capítulo, ou ainda páginas em branco, nas quais sugere que o leitor as complete como bem lhe aprouver. Em uma passagem, seu narrador desenha linhas acidentadas reproduzidas ali, para representar a falta de linearidade de seu discurso. Ao se valer desses recursos, Sterne

Desdenhou, ironicamente, das pinturas de costumes, pinceladas de convenção moral, sempre coerentes, contidas em obras bem divididas e pesadas em suas partes; nelas, seria crime contra a estética qualquer possível enfado por parte do leitor, despertado pela final resolução de um conflito de paixões ou interesses que a instância final do enunciado do autor lhe propiciava. ${ }^{257}$

Em seu romance, Sterne propõe contar biografia de Tristram Shandy, o narrador em primeira pessoa. No entanto, Tristram não consegue encadear a história, nela interpondo múltiplas digressões e comentários periféricos sobre outras personagens, que impedem o avanço do suposto assunto principal. Percebe-se uma manipulação das

\footnotetext{
${ }^{255}$ FRIEDRICH, Hugo, 1978, p.87.

${ }^{256}$ PAES, José Paulo. "Sterne, ou o horror à linha reta", in: A vida e as opiniões do cavalheiro Tristram Shandy. Tradução, introdução e notas de José Paulo Paes. Rio de Janeiro: Nova Fronteira, 1984, p.19.

${ }^{257}$ BRAYNER, Sônia. "O teatro do mundo na ilusão romanesca". In: O labirinto do espaço romancesco. Rio de Janeiro, MEC/Civilização Brasileira, 1979, p. 73.
} 
expectativas convencionais do leitor, por meio das "sutis manobras shandianas de promessa e despite, de incitação e desapontamento" ${ }^{258}$, orquestradas pelo narrador intruso. O resultado é um extravagante e humorado livro, "ostensivamente escrito para frustrar as expectativas do leitor comum". ${ }^{259}$ Seu narrador satiriza a história centrada apenas nos acontecimentos, no estilo ação puxa ação, sem apresentar matéria para reflexão.

Conforme Sônia Brayner afirma, a paródia do gênero biografia nesse romance de Sterne tem como ponto de partida captar o papel da subjetividade na apreensão dos objetos do mundo. Ali, o fluxo de pensamento contrasta com a representação do tempo objetivo; as percepções do sujeito perante o mundo são embaralhadas numa sucessão indefinida de ideias, que se deslocam livremente. Em outras palavras, A vida e as opiniões do cavalheiro Tristram Shandy é basicamente uma "tentativa de captar a trajetória de uma consciência". ${ }^{260}$ A consciência do contraste entre o tempo objetivo e a duração subjetiva leva ao emprego de "técnicas específicas de retardo e digressão narrativa, assim como a presença de um narrador dramatizado, que comanda as atitudes fundamentais do ato de narrar." O pseudoautor Tristram embaralha também realidade e ficção em sua "biografia", e permanece ciente da "intangibilidade do real, convencido de que só se tem imagens descoloridas e parciais do mundo". A representação da realidade é marcada no romance pela constante afirmação da artificialidade dessa mesma representação. As digressões orquestram a quebra de ilusão dramática:

A digressão é um artifício deliberadamente utilizado no Tristram Shandy para desviar o foco de interesse dos sucessos em si para a maneira por que são narrados. E esse desvio faz com que a luz incida mais no narrador do que em seus personagens, num lance típico daquela técnica do narrador intruso ou dramatizado. $^{261}$

Ao se valer de piruetas narrativas extravagantes e da predominância da reflexão fragmentária, Sterne abala o conceito de mimesis, pois coloca perigosamente em risco o efeito de unidade do romance:

Sterne resolve deliberadamente romper com o formalismo neoclássico em vigência, rejeita a cômoda estrada épica e retórica dominante e desloca o acento da narrativa das ações para as "opiniões", do exterior para o interior.

\footnotetext{
${ }^{258}$ PAES, 1984, p.38.

${ }^{259}$ Idem, idem, p.07.

${ }^{260}$ BRAYNER, 1979, p.75.

${ }^{261}$ PAES, 1984, p. 35.
} 
Vai propor uma obra em que as opiniões do protagonista, suas digressões sobre episódios e pessoas, sua ironia frente à sociedade e comportamento humanos, assumem desde o início uma importância igual à história de sua vida. Com isto, opondo-se à tradição narrativa de seu tempo, tenta a aventura de unir a ação e a reflexão, fundindo a matéria romancesca e o ensaio, problematizando as questões fundamentais do ser humano. Destrói conscientemente o conceito de enredo (plot), optando pela incessante fragmentação da narrativa. ${ }^{262}$

Nas palavras de José Paulo Paes, "a narrativa de Tristram não persegue um fim — o desfecho da trama - mas deixa-se levar pelos caprichos de sua pena" ${ }^{263}$ e cria "um romance de viés ostensivamente psicológico, voltado mais para a compreensão dos motivos de seus personagens do que para os seus atos propriamente ditos". ${ }^{264}$ Entram em confronto as diferentes temporalidades da escrita e do pensamento: "A vida sempre na dianteira da pena que não consegue jamais alcançá-la". ${ }^{265}$ Devido a esse teor essencialmente reflexivo a obra pode ser considerada metarromance, romance sobre o romance ${ }^{266}$, pois funde o gênero do ensaio teórico na narrativa literária.

Esta obra é a tal ponto aberta que até hoje suscita especulações se Laurence Sterne a teria terminado. Esta impressão de inacabamento não impediu que ele se tornasse "um pároco de sucesso" junto ao público ${ }^{267}$, mais entusiasmado com ela do que muitos críticos literários de seu tempo: "A crítica não via com bons olhos as peripécias da temporalidade nos romances de Sterne, culpando sua volubilidade imaginativa destes artifícios exagerados e retóricos". 268

O romance de Denis Diderot, denominado Jacques, o fatalista, seguiu a mesma trilha experimental de Sterne, alguns anos depois. Nele também se verifica o truncamento da narrativa, uma promessa de narrar uma história, que divide seu espaço entre constantes comentários sobre a forma. Jacques tenta contar ao amo a história de seus amores durante uma viagem, mas ela é interpolada por outras longuíssimas histórias, assumidas por diferentes narradores. Numa passagem do romance, há uma pausa na ação, na qual se discute qual direção o enredo deve seguir:

Leitor (...) Estou metido num impasse à Voltaire, ou, como se diz vulgarmente, num beco sem saída, de onde não sei como sair; entrego-me,

\footnotetext{
${ }^{262}$ BRAYNER, 1979, p. 73.

${ }^{263}$ PAES, 1984, p.38.

${ }^{264}$ Idem, idem, pp. 14-15.

${ }^{265}$ Idem, idem, p.40.

${ }^{266}$ Idem, idem, p.39.

${ }^{267}$ A expressão é de José Paulo Paes.

${ }^{268}$ BRAYNER, 1979, p.75.
} 
por isso, a um conto feito para agradar, a fim de ganhar tempo e de encontrar algum meio de sair da história que comecei. ${ }^{269}$

A exposição desses rodeios e dilemas gera o efeito de uma composição criativa em processo. Em um outro trecho, o narrador ri da tolerância do leitor diante das suas digressões: "Leitor, a paciência com que me ouvis prova o pouco interesse que tendes por meus personagens; sinto-me tentado a deixá-los onde estão". ${ }^{270}$ De modo análogo, o protagonista Jacques interrompe a todo momento as narrativas engendradas pelas demais personagens, com comentários paralelos, responsáveis por unificar as primeiras em uma espécie de moldura, sintetizada na figura de Jacques. Tal como ocorre no caso da biografia inacabada de Tristram Shandy, a história dos amores de Jacques permanece em aberto, pendente, ao abrir espaço para que outras narrativas menores se desenvolvam em seu interior, como é o caso do relato paralelo sobre a vingança de Madame Pommeraye, que Jacques e seu amo ouvem de uma hospedeira durante uma pausa para descanso em sua viagem.

Sônia Brayner afirma que esse tipo de narrativa experimental foi produzida por uma linhagem de ironistas, inclinados à paródia e à intertextualidade. Dentre eles, Brayner cita Cervantes, Fielding, Sterne, Rabelais, Swift e Machado de Assis. ${ }^{271}$ Dom Quixote é uma das fontes mais recorrentes para os autores citados, sendo "sem dúvida o mais importante romance a utilizar um narrador dramatizado, consciente e intruso". 272

$\mathrm{Na}$ "Carta sobre o romance", Friedrich Schlegel, defende as extravagâncias formais de Laurence Sterne e Denis Diderot, incorporando a eles o nome do alemão Jean Paul. Antonio, o narrador da carta composta por Schlegel, debate com a amiga a avaliação negativa que ela tece sobre os escritos de Paul. Segundo Amália, as obras dele não podem sequer ser consideradas romances, "mas um colorido pastiche de espiritualidade doentia"; suas histórias, ela argumenta, são mal apresentadas, a ponto de obrigar o leitor a adivinhá-las. Além disso, Amália o acusa "de modo quase desdenhoso de ser um sentimental". 273

269 DIDEROT, Denis. Jacques, o fatalista, e seu amo. Tradução, apresentação e notas de Magnólia Costa Santos. São Paulo: Nova Alexandria, 2001, p.84.

270 Idem, idem, p.69.

271 BRAYNER, 979, p.72. O estudo de Sonia Brayner explora o diálogo formal de Machado de Assis com Sterne, e a tendência à auto-ironia na escrita de ambos. Brayner ainda cita as obras de Erasmo, Rabelais, Diderot e dos Enciclopedistas como exemplos dessa "linhagem de ironistas".

272 Idem, idem, p.76.

273 SCHLEGEL, Friedrich. "Carta sobre o romance", in: Conversa sobre poesia e outros fragmentos. Tradução, prefácio e notas: Victor-Pierre Stirnimann, São Paulo, Iluminuras, 1994, pp.61-64. 
Baseando-se na concepção de poesia sentimental de Friedrich Schiller, Antonio explica que as obras modernas são sentimentais, não no sentido corriqueiro atribuído à palavra: elas evocam a busca pela forma ideal, reconstituída artificialmente por meio da reflexão; aspiram ao "mais elevado e infinito", representável somente por meio de uma linguagem enigmática, hieroglífica, fantástica: “A fantasia luta com todas as forças para se exteriorizar, mas o divino só se comunica e exterioriza indiretamente, na esfera da natureza". ${ }^{274}$ A noção de "poesia sentimental" está intimamente ligada ao romantismo: "romântico é justamente o que nos apresenta um conteúdo sentimental em uma forma da fantasia".

Antonio elenca, além de Sterne, Diderot e Jean Paul, os nomes de Shakespeare, Tasso, Ariosto, Boccaccio e Cervantes como antecedentes da literatura romântica. Nas obras desses autores, é destacada a tendência à fantasia e ao fabuloso, caracterizadora dos antigos romanzos. Antonio revela o seu desejo de compor um "romance que reproduzisse fantasticamente cada nota eterna da fantasia e que de novo gerasse o caos do mundo dos cavaleiros andantes", e mesclasse narrativa, drama, canção e outros gêneros possíveis. Ele chega a discutir o parentesco do romance com a narrativa épica, salientando que a unidade de ação, própria do épico, se afasta da representação da multiplicidade buscada no romance. O poeta sentimental "de modo algum enclausura e fixa seu interesse em pessoas, acontecimentos, situações e inclinações individuais"275, pois:

O contexto dramático da história não faz do romance de modo algum, um todo, uma obra; isto ele se torna através da relação da composição toda com uma unidade superior àquela unidade da letra - com a qual ele frequentemente não se deve importar — , através da sequência das ideias, através de um centro espiritual. ${ }^{276}$

O narrador que se deixa levar por seu "próprio humor, do jogar com ele, como acontece nos melhores romances", é o que há de "mais oposto ao estilo épico"277, no qual se procura instaurar a ilusão de realidade, apagando ao máximo a presença da mediação do narrador. O artista romântico coloca-se a missão paradoxal de recriar uma

\footnotetext{
${ }^{274}$ Idem, p.65-66. Para consultar a teorização de Friedrich Schiller sobre a poesia moderna como "sentimental", cf. SCHILLER, Friedrich. Poesia ingênua e sentimental. Trad. Márcio Suzuki. São Paulo: Iluminuras, 1991. Para Antonio, A vida e as opiniões do cavalheiro Tristram Shandy, Jacques o fatalista e as obras de Jean Paul não são exemplos de realização da bela forma ideal, o que, segundo ele, não os impede de enriquecer a fantasia de seus leitores.

275 SCHLEGEL, F., idem, pp. 65-66.

${ }^{276}$ Idem, idem, p.67.

${ }^{277}$ Idem, idem, p.68.
} 
“confusão artificialmente ordenada, esta excitante simetria de contradições, este maravilhoso e eterno jogo alternado de entusiasmo e ironia". ${ }^{278}$ E se fascina com a loucura, a "coisa mais linda que pode o homem imaginar, o verdadeiro princípio supremo de tudo o que é divertido". 279

A poesia antiga, "ingênua" — conforme a concebe Schiller —, faz coincidir forma e conteúdo de maneira harmônica e completa. Num contexto intelectualizado e artificializado, as forças primordiais da antiga natureza da arte estão perdidas. Por isso, "o que cresceu em circunstâncias tão doentias naturalmente não pode deixar de ser, ele próprio, doentio". ${ }^{280}$ Para Antônio, de "Carta sobre o romance", a obra de Jean Paul é uma manifestação por excelência da poesia sentimental: "situo Richter num plano superior ao de Sterne, porque sua fantasia é muito mais doentia, e assim também muito mais extravagante e fantástica". Justamente esses traços, tendentes ao disforme, colocam em descrédito o estilo de Jean Paul aos olhos de Amália, no início da carta de seu amigo. Vale lembrar que, ao modo de Antonio, o enunciador de $O$ poema do frade defende a sua escrita, tendente ao disforme, como uma opção estética legítima e desejável, em detrimento dos "versos eloquentes" e " bem rimados":

\footnotetext{
Que prantos! que suspiros sufocados! Se eu gostasse dos versos eloquentes, Como eu descreveria bem rimados Do meu peito os anélitos frementes! Porém no seio eu sufoco tudo, Porque da mágoa o serafim é mudo. ${ }^{281}$
}

A mudez do poeta, acima aludida, pode ser tomada como expressão de um sublime silêncio, assunto desenvolvido no capítulo final desta dissertação.

\footnotetext{
${ }^{278}$ SCHLEGEL, F. "Discurso sobre a mitologia”, 1994, p.55.

${ }^{279}$ Idem, "Carta sobre o romance", 1994, p.64.

${ }^{280}$ SCHLEGEL, F., idem, p. 63.

${ }^{281}$ AZEVEDO, Álvares de. "O poema do frade", 2002, Canto Quinto, estr. XXVII, p. 356.
} 


\title{
CAPÍTULO III
}

\section{Falência da epopeia}

\begin{abstract}
A maior desgraça deste mundo é ser Fausto sem Mefistófeles...

Álvares de Azevedo, Macário. ${ }^{282}$
\end{abstract}

\section{A poesia venal}

Embora as estrofes finais do Canto Primeiro de $O$ poema do frade anunciem uma epopeia, em estâncias anteriores o narrador já admitira a impossibilidade de concretizar esta proposta. A ação do poema alvaresiano não é situada em um passado lendário, mas nos tempos modernos, caracterizados em seus versos como uma noite convulsa, passada em meio a bordéis e prostitutas, vislumbrada por entre a fumaça do charuto e os efeitos atordoantes da embriaguez. O tempo de ruínas destoa daquele da epopeia, no qual o herói épico era elevado a mito e eternizava os seus feitos bélicos. $\mathrm{O}$ herói Jônatas, de $O$ poema do frade, por sua vez, posiciona-se com ceticismo diante da realidade em que vive, dominada por valores puramente materiais. Ele está ciente de que não há qualquer possibilidade de reviver a glória do mundo épico, relegado à memória nostálgica. Jônatas "sonhava sim em tradições guerreiras,/ Nos cânticos de bardo sublimado..../ Mas nas épicas sombras do passado.”283 A inserção da conjunção adversativa no último desses versos citados reforça a consciência da personagem a respeito da perda dessa idade de ouro da humanidade, lembrada apenas como uma sombra distante. No mundo presente, o ideal épico pode reviver somente em sonho. A posição marginalizada de Jônatas em sua sociedade também destoa daquela gozada pelo "bardo sublimado" no mundo antigo, tido como herói coletivo, quando ocupava a posição de destaque dos guerreiros, sábios e santos —, e a poesia era encarada como a grande educadora da humanidade. ${ }^{284}$ Jônatas, por outro lado, é um poeta venal que vive

\footnotetext{
${ }^{282}$ AZEVEDO, Álvares de. Macário”. In: Macário; Noite na taverna. Organização, notas e prefácios de Cilaine Alves Cunha. São Paulo: Editora Globo, 2007, p. 38.

${ }^{283}$ Idem. "O poema do frade", in: Poesias completas; edição crítica de Péricles Eugênio da Silva Ramos; Iumna Maria Simon (org), Campinas, SP: editora da Unicamp, São Paulo: Imprensa Oficial do Estado, 2002, p. 314.

284 Sobre o tema da poesia como educadora da humanidade, cf. JAEGER, Werner. Paideia: A Formação do Homem Grego. São Paulo: Martins Fontes, 1995. Vale lembrar que na Carta a D’Alembert, Rousseau lamenta a situação do teatro contemporâneo, encenado em ambientes privados, que estimulam o
} 
uma realidade incapaz de conferir ao escritor o heroísmo ou a glória, quando a poesia é rebaixada a mais uma mera mercadoria entre tantas outras:

\author{
Dizer que era poeta - é cousa velha: \\ No século da luz assim é todo \\ O que herói de novelas assemelha. \\ Vemos agora a poesia a rodo! \\ Nem há nos botequins face vermelha, \\ Amarelo caixeiro, alma de lodo, \\ Nem Bocage d'esquina, vate imundo, \\ Que não se creia um Dante vagabundo! ${ }^{285}$
}

Ser poeta "No século da luz" é "cousa velha", encarada como ultrapassada ou inútil. O mundo maravilhoso e fabuloso da poesia épica antiga entra em conflito com a concepção de tempo burguês, racionalizado e utilitário. ${ }^{286}$ Sem a proteção do mecenato, o artista procura sobreviver dentro dos mecanismos de produção burgueses, e vê-se perante o dilema de ceder a eles, rebaixando o produto de seu gênio às exigências do mercado; ou então decide resistir a este sistema, lutando pela defesa de sua liberdade e individualidade criativa, marginalizando-se. No processo de mercantilização do lazer e da cultura, o poeta que declama para as grandes plateias é visto como alguém que cede à banalização da poesia na obra de Álvares de Azevedo. Mesmo o reconhecimento do poeta que aceita submeter-se à moda é efêmero e logo esquecido. O prêmio da imortalidade conquistada pelos poetas antigos não pode ser alcançado em uma realidade esvaziada pelas relações de consumo. Nesse sentido, o poeta Jônatas surge distanciado do público, pois "não se imprimia/ Nem versos no teatro declamava!". ${ }^{287} \mathrm{O}$ artista moderno não pode ou simplesmente se recusa exercer o seu talento nas condições de produção que o cercam. A divisão de trabalho e a pressa da linha de produção, destinada a gerar lucro cada vez mais rápido, agradando às vontades do público volúvel, impedem que ele se dedique satisfatoriamente a seu trabalho ou desenvolva a sua originalidade. Porém, como artigo raro, a própria originalidade se converte em mais um produto de luxo, desejado, negociado e acomodado ao imperativo de lucro mercantil. ${ }^{288}$

isolamento, e que e se distancia dos eventos teatrais cívicos e ao ar livre do mundo antigo. Cf. ROUSSEAU, Jean-Jacques. Carta a D’Alembert. Campinas: Editora da Unicamp, 1993.

285 AZEVEDO, Álvares de. "O poema do frade", 2002, Canto Primeiro, estr. XXV, p. 313.

${ }^{286}$ SAFRANSKI, Rüdiger. "Capítulo X”, in: Romantismo: uma questão alemã. Tradução de Rita Rios. São Paulo: Estação Liberdade, 2010, p. 180.

${ }^{287}$ AZEVEDO, Álvares de. "O poema do frade", 2002, Canto Primeiro, estr. XXVI, p. 313.

288 "A poesia é útil para o filisteu, contanto que ela — qual uma interrupção rejuvenescedora reconstrua a usual capacidade para o trabalho. Os filisteus são seres sem transcendência; fazem tudo pelo amor da vida terrena. Querem viver esta vida terrena sempre como igual; sua identidade lhes é valiosa; 
A ausência de um herói contemporâneo leva Byron a exumar o último deles, conforme destaca Laymert Garcia dos Santos. No Canto Primeiro de Don Juan, Lord Byron almeja invocar um herói contemporâneo para a sua "sátira épica", no entanto se depara somente com uma "série de simulacros de heróis" 289 , produzidos em série:

Quero um herói: querer incomum,

Quando cada ano e mês nos oferece um novo,

Até que, depois de saturar as gazetas da hipocrisia,

A época descobre que ele não é o verdadeiro:

De tais como este, não teria o cuidado de louvar,

Portanto tomarei nosso velho amigo Don Juan -

Nós todos o vimos, na pantomima,

Mandado para o diabo um pouco antes do tempo. ${ }^{290}$

O sonho do herói moderno permanece como ideal da imaginação: o Don Juan byroniano é um fantasma, perseguido pelas mulheres que o desejam; uma imagem que "não age, posa". ${ }^{291}$ No século XIX, ele deixa gradativamente de vagar mundos para se restringir cada vez mais a espaços privados, ocupados pelo tédio e pela melancolia. ${ }^{292}$

Diante deste panorama, é sintomática a caracterização de Jônatas como um poeta libertino, voltado à rebeldia e à transgressão. Ao descrever o seu modelo de herói, o narrador cria outro critério de nobreza, caracterizado pela revolta, misantropia e orgulho. Além disso, estende todos os vícios da personagem, tais como a preguiça e a embriaguez, como hábitos comuns ao leitor, universalizando o espírito dissoluto como traço unificador dos tempos modernos ${ }^{293}$ :

\author{
Meu herói é um moço preguiçoso \\ Que viveu e bebia por ventura \\ Como vós, meu leitor... se era formoso \\ Ao certo não o sei. Em mesa impura \\ Esgotara com lábio fervoroso
}

querem, sob qualquer hipótese, permanecer previsíveis para si e para os outros”, in: SAFRANSKI, Rüdiger, idem, p. 182.

289 SANTOS, Laymert Garcia dos. "Don Juan e o nome da sedução". In: A sedução e suas máscaras: ensaios sobre Don Juan. São Paulo: Companhia das Letras, 1988, pp. 32-33.

${ }^{290}$ BYRON, Lord. Don Juan, apud. SANTOS, Laymert Garcia dos, 1988, pp. 32-33.

${ }^{291}$ A expressão é de Laymert Garcia dos Santos.

292 SANTOS, Laymert Garcia dos, op. cit, idem.

293 Segundo Cilaine Alves Cunha, em Noite na taverna, de Álvares de Azevedo, "a disseminação da degradação moral pelo mundo acaba também por selar o processo de transmutação do passado das ilusões num eterno presente de devassidão e crime, reafirmando o destino trágico da poesia e dos poetas que, no passado de suas juventudes, prometiam, em seus versos, otimismo e esperança, transformando-os no entanto numa narrativa macabra". O "vazio das utopias" no tempo presente está em consonância com uma "visão cética que decreta o fim do passado idílico" e anuncia o vigor da "essência eminentemente imoral da arte", representada pela imagem da prostituta e do poeta libertino. Cf. CUNHA, Cilaine Alves. "Intersecção de Macário e Noite na taverna". in: In: Macário; Noite na taverna. Organização, notas e prefácios de Cilaine Alves Cunha. São Paulo: Editora Globo, 2007, pp. 199-200. 
Como vós e como eu a taça escura.

Era pálido sim... mas não d'estudo :

No mais... era um devasso e disse tudo $!^{294}$

Os traços físicos da personagem são indeterminados ("se era formoso/ Ao certo não o sei”), aspecto que favorece a sua alegorização, tornando-a encarnação de princípios e conceitos. Sem discorrer sobre possíveis cores de cabelo ou olhos, por exemplo, o narrador insiste na palidez do libertino, resultante de suas experiências físicas intensas, relacionadas sobretudo à voracidade de suas bebedeiras. $\mathrm{O}$ "preguiçoso" e "devasso" Jônatas cultiva hábitos boêmios, marcados pelo excesso e pelo desregramento: "Amar, beber, dormir, eis o que amava:/ Perfumava de amor a vida inteira,/ Como o cantor de Don Juan pensava/ Que é da vida o melhor a bebedeira.../ E a sua filosofia executava....". 295 Ele desdenha os interesses bélicos e políticos de seu tempo ("do povo e dos reis escarnecia"), além de se mostrar descrente da religião. A ausência de virtude, de vigor físico, de fé no divino e de otimismo no tempo presente são aspectos que distanciam Jônatas do modelo do herói de uma Odisseia segundo os padrões antigos. Dentro da mesma perspectiva, sua linhagem social é apresentada de maneira indeterminada:

\footnotetext{
Se era nobre ou plebeu, ou rico ou pobre

Não vos direi também: que importa o manto

Se é belo o cavaleiro que ele cobre?

E que importa o passado, um nome santo

De pútridos avós? plebeu ou nobre

Somente a raiva lhe acordava o pranto.

Embuçada no orgulho a fronte erguia

E do povo e dos reis escarnecia! ${ }^{296}$
}

A caracterização da personagem se faz sobretudo pela ausência de traços objetivos, dentro da tendência do narrador a omitir informações ("Não vos direi também"). Vale notar que as omissões sobre a linhagem, acima, não se dão por desconhecimento do narrador, mas para enfatizar a sua desconsideração a ela. $\mathrm{O}$ indivíduo é valorizado segundo a sua capacidade de subversão ou ruptura em relação à realidade e à tradição, e não por sua posição na continuidade de uma linhagem. A dissonância em relação ao modelo do herói épico tradicional torna-se evidente no final do Canto Primeiro de $O$ poema do frade, quando o narrador refere-se, ironicamente, a si

\footnotetext{
${ }^{294}$ AZEVEDO, Álvares de. Canto Primeiro, estr. XXXIV. In: “O poema do frade”, 2002, pp. 312-313.

${ }^{295}$ Idem, Canto Primeiro, estr. XXXIII, p. 315.

${ }^{296}$ Idem, Canto Primeiro, estrofe XXVII, p. 313.
} 
mesmo como o "sublime autor desta epopeia", ou ainda a Jônatas como o herói de uma "glória não sabida" "nesta Odisseia". Ao fazer essa associação, o herói do poema alvaresiano é confrontado com o modelo de Ulisses, o guerreiro célebre, prudente e corajoso dos poemas homéricos. Em consonância com o padrão nobre dos heróis antigos, Ulisses pode ser pensado segundo os traços elencados por Ernst Robert Curtius:

\begin{abstract}
A ideia do herói relaciona-se com o valor vital da nobreza. Herói é o tipo humano ideal, com o centro de seu ser fixado na nobreza e suas realizações, portanto em valores vitais "puros" e não técnicos, e cuja virtude fundamental é, naturalmente, a nobreza do corpo e da alma. $\mathrm{O}$ herói distingue-se por uma excessiva vontade espiritual e por sua concentração em face da vida instintiva. É o que constitui sua grandeza de caráter. A virtude específica do herói é seu autocontrole. Mas a vontade do herói visa ainda ao poder, à responsabilidade, à audácia. Pode, assim, aparecer como estadista e general, como nos tempos antigos se apresentava como guerreiro. ${ }^{297}$
\end{abstract}

Embora Jônatas seja denominado um herói de "Odisseia", o seu caráter nada virtuoso, bem como a sua condição de anônimo, em conflito com a sociedade, destoam do modelo de Ulisses e do herói convencional de epopeia, dotado de ilustre descendência, riqueza aristocrática, espírito de liderança e equilíbrio. Dentre os heróis épicos, Ulisses é aquele que melhor conjuga a força física e a razão, numa relação que faz dele "o ideal da virtude do guerreiro". ${ }^{298}$ Sua condição especial de homem maduro, a meio caminho entre a vitalidade física juvenil e a sabedoria astuciosa do ancião, corresponde a sua eloquência e habilidade nos feitos, capacidades notáveis que lhe conferem valor e fama.

Como Alexandre Herculano assinala, o herói épico é um "typo ideal da humanidade", demonstrando uma "estrutura moral superior à nossa". ${ }^{299}$ Sua grandiosidade é incompatível com o mundo prosaico do século XIX; a paisagem épica é o espaço aberto, os vastos campos ocupados por enormes exércitos, marchando em unidade em torno de um mesmo ideal. Em O poema do frade, o herói é ambíguo e solitário, e pouco age; não há um inimigo definido contra quem se rebelar. O inimigo de Jônatas é a sociedade que oprime a expansão dos supostos talentos individuais. Na epopeia, há um inimigo comum contra uma comunidade. Jônatas é uma personagem urbana, circulando em espaços fechados, como a taverna e o prostíbulo. Seu corpo

${ }^{297}$ CURTIUS, Ernst Robert. "Heróis e soberanos", in: Literatura Europeia e Idade Média Latina. São Paulo: Hucitec/Edusp, 1996, p. 223.

${ }^{298}$ Idem, p.227.

299 Cf. HERCULANO, Alexandre. "Alexandre Herculano crítico da Confederação", in: RAEDERS, Georges. Dom Pedro II e os sábios franceses. Rio de Janeiro: Atlântica Editora, 1944, pp. 201-215. 
geralmente está prostrado sobre o leito, sob o efeito das orgias e da embriaguez, ou ainda da febre que atribula seu pensamento com o "atropelar de mil ideias". 300

Há uma unidade entre a "nobreza do corpo e da alma" do herói épico antigo, bem como entre o mesmo e a sociedade. Jônatas, por outro lado, é caracterizado pela cisão interior, pela dúvida e desconfiança da realidade. Sua posição diante dos reis e do povo é de escárnio, recusando-se a participar da vida política:

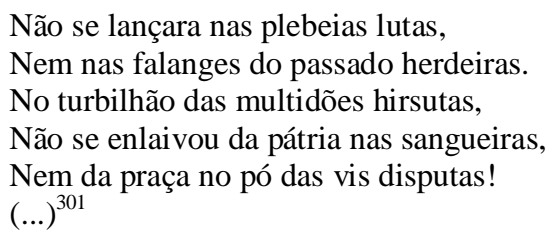

O herói épico antigo representa a unidade coletiva, ao passo que o heroísmo de Jônatas decorre de sua condição solitária, entorpecida e elegíaca perante uma realidade mediada pelas trocas mercadológicas. Segundo João Adolfo Hansen, a epopeia está intimamente relacionada às instituições do mundo antigo; ela propõe a narração da "ação heroica de tipos ilustres, fundamentando-a em princípios absolutos, força guerreira, soberania jurídico-religiosa, virtude fecunda" ${ }^{302}$; todavia esses valores entram em derrocada com a falência do Antigo Regime e a instauração do modo de organização social pautado pela livre-concorrência burguesa, que eleva o dinheiro a mais alto valor, em detrimento dos grandes feitos oriundos de virtude heroica e divina. ${ }^{303}$ Jônatas não é um general maduro, forte e reconhecido; é um jovem poeta atormentado, empobrecido, libertino, desconhecido. Seu corpo frágil sucumbe aos vertiginosos delírios de sua mente e aos vícios de seu corpo. A sua visão da realidade é pautada pela negatividade e pela crítica:

\footnotetext{
O presente julgava um mar de lama

Onde vis ambições se debatiam,

Ruína imunda que lambera a chama:

Cadáver que aves fétidas roíam!

Tudo sentiu venal! e ingrata a fama!

Como torrentes trépidas corriam

As glórias, tradições, coroas soltas

De um mar de infâmias às marés revoltas! $!^{304}$
}

\footnotetext{
${ }^{300}$ AZEVEDO, Álvares de. O poema do frade, 2002, Canto Segundo, estr. XIII, p. 320.

${ }^{301}$ Idem, idem, Canto Primeiro, estrofe XXVIII, pp. 313-314.

${ }^{302}$ HANSEN, João Adolfo. "Notas sobre o gênero épico". In: VÁRIOS. Épicos. Organização de Ivan Teixeira. São Paulo: Edusp/ Imprensa Oficial, 2008, p.17.

${ }^{303}$ Idem, idem.

304 AZEVEDO, Álvares de. O poema do frade, 2002, Canto Primeiro, estrofe XXIX, p. 314.
} 
Não há qualquer entusiasmo despertado pelo tempo presente, definido como um "mar de lama", ou como um "Cadáver que aves fétidas roíam", repleto de ruínas. A venalidade é o seu traço principal. Os critérios antigos de nobreza heroica, glória e tradição são desqualificados e esvaziados de sentido em um "mar de infâmias". Longe do horizonte solar e radiante da epopeia, o tempo presente em $O$ poema do frade é a noite tenebrosa e insuportável, da qual Jônatas deseja alienar-se, por meio da embriaguez:

\author{
Não quisera mirar a face bela \\ Nesse espelho de lodo ensanguentado! \\ A embriaguez preferia: em meio dela \\ Não viriam cuspir-lhe o seu passado! \\ Como em nevoento mar perdida vela, \\ Nos vapores do vinho assombreado \\ Preferia das noites na demência \\ Boiar (como um cadáver!) na existência! $!^{305}$
}

Diante desta realidade hostil à poesia, Álvares de Azevedo mostra a figura do poeta "ora como o supremo sonhador, criador de ideais, ora como alvo de zombaria ou objeto de descrédito social". ${ }^{306}$ Wellington de Almeida Santos lembra a atitude de Puff no poema "Boêmios", que encomenda um soneto de Níni para servir de "passaporte amoroso", como é o caso também de "Namoro a cavalo", no qual a poesia é rebaixada a "alcoviteira". Para Santos, a postura hostil de Jônatas perante o público no Canto Primeiro de O poema do frade revela um "isolamento voluntário", pois "o poeta do ideal constata que canta para um mundo sem ouvidos e seu destino é a miséria social". ${ }^{307}$ A personagem Tancredo de "Um cadáver de poeta" finda ingloriamente: "Morreu um trovador - morreu de fome".

O desejo de Jônatas é apressar a própria morte, em um mundo sem espaço para poetas como ele. Seu perfil libertino e suicida é análogo ao da personagem Jacques Rolla, do poeta francês Alfred de Musset, longamente analisada no ensaio literário de Álvares de Azevedo, denominado "Alfredo de Musset: Jacques Rolla". Nele, Azevedo aponta em Rolla um perfil especial, que ele denomina "um caráter de poeta": é uma personagem capaz de apreender as contradições do mundo presente, dividida pela "luta

\footnotetext{
${ }^{305}$ AZEVEDO, Álvares de. O poema do frade, 2002, Canto Primeiro, estrofes XXIX e XXX, p.314.

${ }^{306}$ SANTOS, Wellington de Almeida. "Álvares de Azevedo e a ironia romântica", in: Obra completa, BUENO, Alexei (org.) Rio de Janeiro: Nova Aguilar, 2000, p. 102.

${ }^{307}$ Idem, idem, p. 104.
} 
entre crença e marasmo", e pela inserção oscilante entre as ruínas do velho mundo e o vislumbre de um futuro incerto. O herói libertino experimenta a prostituição, o dinheiro e a fome, mas se mantém "belo ainda"; seu canto hesitante e marcado pelo dilema é uma "melodia doce e triste a um tempo". ${ }^{308}$ Segundo Azevedo, Musset assimila de Byron o tema da luta interior, o conflito subjetivo de um eu lutuoso, precocemente envelhecido pelo sofrimento constante:

\begin{abstract}
Não há aí o poema do materialismo impuro a revolver-se como um verme em lodaçal. — Não: é antes uma luta entre o corpo e a alma — entre a morte e a vida - entre o céu e a terra — entre as melodias de Ariel e o fel de Calibã perdido nos sonhos das noites de verão de Shakespeare, - entre a negridão da noite e a luz doirada da lâmpada mal guardada ao róseo dos dedos transparentes da virgem que passa pelas ousias do claustro a desoras — é o pleito, agro e renhido sim das aspirações ao céu. ${ }^{309}$
\end{abstract}

O perfil libertino e o projeto suicida de Rolla são incorporados por Jônatas em $O$ poema do frade, no qual também elege-se uma prostituta especial com quem o herói passa a sua derradeira noite. Segundo Vagner Camilo, o diálogo alvaresiano com o modelo de Jacques Rolla realiza-se por meio da exploração dos temas do erotismo, do individualismo exacerbado, da rebeldia moral e do cinismo. ${ }^{310}$ A pobreza econômica que aflige Jônatas e Rolla é semelhante a outro perfil analisado em mais um ensaio de Álvares de Azevedo; trata-se de Aldo, o poeta miserável de autoria de Georg Sand. Ele, à maneira dos outros dois, sucumbe às contradições do tempo presente. ${ }^{311}$

De acordo com Alcides Villaça, os heróis malditos de Álvares de Azevedo habitam o mundo prosaico da segunda parte de Lira dos vinte anos, na qual vigora a realidade "da garrafa de conhaque, do charuto, do quarto desarrumado, da roupa suja". Suas personagens em crise profunda são conscientes do rebaixamento da vida a um grande mercado; aí, resta ao poeta cantar "com os boêmios, com os vagabundos, com os filhos de Satã" e ironizar a imagem do artista sonhador no mundo hostil à poesia, dividido entre as limitações do cotidiano e as aspirações da fantasia. ${ }^{312}$ Nesse sentido, pode-se pensar a maneira obscura e indeterminada com que a origem social de Jônatas é

\footnotetext{
308 AZEVEDO, Álvares de. “Alfred de Musset: Jacques Rolla”. In: Obra completa, BUENO, Alexei (org.) Rio de Janeiro: Nova Aguilar, 2000, p.700.

309 Idem, idem, p.699.

310 CAMILO, Vagner, Vagner. Risos entre pares: poesia e humor românticos. 1a. ed. São Paulo: Edusp/Fapesp, 1997, pp. 64-67.

${ }^{311}$ AZEVEDO, Álvares de. "Georg Sand: Aldo, o rimador", in: 2000, pp. 662-677.

312 VILLAÇA, Alcides. "Na intimidade romântica". In: AZEVEDO, Álvares de. Lira dos vinte anos. São Paulo: FTD, 1994, pp. 14-21.
} 
delineada em O poema do frade, como se a personagem não tivesse passado e nem futuro. Somente as suas experiências libertinas recentes são aludidas, o que gera o efeito de um paradoxal presente eterno.

Jacques Rolla não fornece somente o modelo para o herói libertino e problemático de $O$ poema do frade. A angelical prostituta Marion é uma das referências para a composição de Consuelo, misto de prostituta e santa. A "celebração do amor profano às prostitutas" é uma variante do tema da poesia venal. Wellington de Almeida Santos cita a recorrente imagem de Madalena na poética alvaresiana, mescla de "santidade e degradação". ${ }^{313}$ Tal como o "caráter de poeta", o perfil da prostituta permite explorar o tema da impossibilidade do ideal no mundo da troca mercantil. Marion é "o anjo da prostituição", a virgem ainda infantil, vendida pela mãe empobrecida. Consuelo, por sua vez, é completamente solitária em $O$ poema do frade; assim como Jônatas, sobre ela são omitidas todas as informações sobre uma possível história familiar ou social, anterior à situação em que ela se encontra. No Canto Segundo de O poema do frade, Jônatas contempla Consuelo adormecida e reflete sobre "a loucura de amar uma perdida". Mesmo consciente da impossibilidade do amor ideal em um mundo degradado, ele se deixa fascinar pela beleza da moça, simultaneamente prostituta, "Madona" e "querubim". A relação do poeta Jônatas com a prostituta Consuelo é análoga à do artista moderno perante a poesia, rebaixada a mais uma mercadoria entre tantas outras:

\begin{abstract}
A abundância de referências à venalidade das relações amorosas e poéticas sugere que o procedimento não é ocasional na obra do poeta. Pelo contrário, frequentemente as imagens ligadas ao mundo da prostituição se ampliam para além do espaço físico da mulher e contaminam tanto o próprio poeta como o viver em geral. ${ }^{314}$
\end{abstract}

Wellington de Almeida Santos cita o poema "Glória Moribunda" como exemplo da degradação da figura da mulher e, por extensão, do poeta: "Para um pouco de pão ganhar da turba/ Como teu corpo no bordel profanas./ - Fiz mais ainda! - prostituí meu gênio". Diante do horizonte hostil, o poeta esquálido, em "Hinos do profeta: Um Canto do Século", entrega-se à Morte, a "leviana prostituta" que "Não distingue amantes”. Além da imagem da mulher, a pátria surge também rebaixada à prostituta e escrava - no Canto Terceiro de $O$ poema do frade:

313 SANTOS, Wellington de Almeida. "Álvares de Azevedo e a ironia romântica”, 2000, p.108.

314 Idem, idem, p.106. 
E a pátria que entre as lágrimas d'escrava

Coa face bela gélida, pendia,

Salpicada de lodo em ti sonhava

Como o sol da manhã de uma outra vida?

A pátria! que a infâmia prostituta

Tenta vender no lupanar poluta!

E não erguem-te aí os gritos dela?

Não vês que a forçam, que seus lábios tapam?

$\mathrm{E}$, desgrenhada, rompem-lhe à donzela

Os vestidos que às frias mãos escapam?

Não ouves o tinir de vil dinheiro

E a lúbrica risada do estrangeiro? $?^{315}$

O tema do poeta venal é constante no romantismo, aparecendo em escritos como "Futuro Literário de Brasil e Portugal", no qual Alexandre Herculano compara o vate romântico a uma "alma virgem", e o mundo a um prostíbulo. Herculano lamenta os "poetas vendidos" e corrompidos:

o talento despenha-se, e atufando-se no charco, aceita as lisonjas ou o oiro imundo, que lhe atiram, embriaga-se com os outros perdidos, e renega da missão sacrossanta, que se lhe destinara no céu .

(...) Se o teu hino reboar por essas torpes alcovas, sabe que pouco tardará a hora de te prostituires $(. ..){ }^{316}$

Frente a essas dificuldades, o artista é elevado a herói problemático no romantismo. O seu trabalho é representado em $O$ poema do frade como uma luta com as regras poéticas tradicionais, que são submetidas a revisão. Ao propor o desmonte da forma da epopeia em O poema do frade, Álvares de Azevedo se insurge contra o ideal nacionalista de literatura no romantismo brasileiro, entendido como serviço prestado à pátria e à moral cristã. O indianismo contou com a proteção de Dom Pedro II, patrocinador de muitas obras oficiais —, inclusive, muitas delas tentativas de epopeia, discutidas com maior detalhamento mais adiante neste capítulo.

315 AZEVEDO, Álvares de. "O poema do frade", 2002, Canto Terceiro, estrofes LXII e LXIV, p.337.

${ }^{316}$ HERCULANO, Alexandre. "Futuro Literário de Portugal e do Brasil", In: DIAS, Gonçalves. Poesia e prosa completas. BUENO, Alexei (org). Rio de Janeiro: Editora Nova Aguilar, 1998, p.98. 


\title{
Tempo enoitado: "o cântico dos funerais da crença"
}

No texto "Fase Negra", parte final do ensaio "Literatura e civilização em Portugal", Álvares de Azevedo discorre sobre um mundo crepuscular e apocalíptico desencadeado pela Revolução Francesa. "Fase Negra” abre-se com um curioso paralelo entre o tempo presente, vacilante e indefinido, e o andar cambaleante do poeta Bocage em estado de embriaguez. Percebe-se no texto de Azevedo uma atenção especial em construir uma atmosfera enoitada, repleta de metáforas relacionadas ao vinho e à fumaça. Descreve-se uma cidade de Lisboa decadente, agonizando em uma "fase de marasmo" e tomada por uma de suas piores crises. O poeta Bocage e a capital portuguesa, "rainha dos mares de outrora", estão conectados por um mesmo espírito de época:

\begin{abstract}
[..] não vedes pelo tremendal das ruas da Lisboa imunda do século XVIII um homem que cambaleia e tropeça; roto e desbotado a encostar-se pelas esquinas, tateando as paredes no andar vertiginoso? Lançai um olhar por essa janela a meio cerrada... Não vedes ali na sombra do lupanar o semblante espavorido, o olhar incerto e uns cabelos louros espalhados pela fronte alta, na mão ainda o copo vermelho, nos joelhos a mulher perdida, como o esboço sublime de Holbein, o libertino pintor Alemão, à margem do Elogio da Loucura de Erasmo, na biblioteca de Bal?

Conheceis aquele homem? $?^{317}$
\end{abstract}

A imagem do poeta embriagado e miserável coincide com a de um mundo em agonia: "todo aquele mundo de além-mar, no dizer Bíblico, vacilava como um ébrio", diz Álvares de Azevedo em outro trecho do mesmo ensaio. ${ }^{318}$ Essa atmosfera sufocante assemelha-se a de Noite na taverna, com suas noites frenéticas, repletas de bebidas e prostitutas. A inserção da "janela a meio cerrada" no espaço da taverna em que se encontra Bocage, no excerto acima, é similar àquela encontrada na passagem de Macário para Noite na taverna. Conforme teorizam Veiga Miranda e Antonio Candido, no final de Macário, Satan leva o jovem que dá nome à obra em questão para ver uma orgia. Na cena, encontra-se um grupo de cinco libertinos, que bebem e jogam na companhia de prostitutas; estes, por sua vez, são assistidos e comentados por aqueles outros dois primeiros através de uma janela. Por meio dessa janela se faz a ponte entre os universos de Macário e Noite na taverna, introduzindo o leitor em uma nova

\footnotetext{
317 AZEVEDO, Álvares de. "Literatura e civilização em Portugal”. In: Obra completa, BUENO, Alexei (org.) Rio de Janeiro: Nova Aguilar, 2000, p.736.

318 Idem, p.737.
} 
realidade, profundamente convulsa e extremada, típica do "romance negro". Macário vislumbra da janela a noite demoníaca, onde impera o "incesto, a necrofilia, o fraticídio, o canibalismo, a traição, o assassínio - cuja função para os românticos era mostrar os abismos virtuais e as desarmonias da nossa natureza, assim como a fragilidade das convenções". 319

O ambiente noturno e aterrorizador retratado no ensaio "Fase Negra", em Macário e Noite na taverna também é longamente comentado em outros escritos de autoria de Álvares de Azevedo, como "Lucano", "Alfredo de Musset: Jacques Rolla” e "Aldo, o rimador". Em "Literatura e civilização em Portugal”, Azevedo discorre sobre a infausta inserção de Bocage em um país decadente e periférico, carente da "inspiração de uma literatura contemporânea valente". ${ }^{320}$ Insiste-se muito no texto em questão sobre a vigência do materialismo e do ateísmo que contribuem para tecer a "capela murcha de esperanças" do poeta lusitano, exposto ao "ar mefítico de uma civilização bastarda"321 e decadente. Azevedo insiste também na hipótese do suicídio de Bocage, desencadeada por seu sofrimento e miséria: "Foi bem infeliz! esse fadado louco que não pôde adormecer as suas mágoas, que não na bruteza da embriaguez! essa cabeça insana, ébria de um idear vagabundo". O infortúnio de Bocage "traduz uma era inteira":

Bocage não é um caráter estéril — por único — no historiar da literatura portuguesa. Naquele homem traduz-se uma era inteira. É o espelho onde passa com sua flutuação de luz e sombra no roxo crepuscular de uma nação a hora turva em que tudo se agita lugubremente, como por um enterro ou um nascer doloroso. $^{322}$

A analogia entre o andar cambaleante de Bocage embriagado e o período de crise português aponta para um fenômeno maior, que caracteriza "uma era inteira". Conforme Marshall Berman assinala, Rousseau aponta uma relação entre a sensação de embriaguez e de redemoinho da vida moderna (o "tourbillon social"), caracterizada pelas experiências conflitantes e intensas da sociedade urbana e industrializada, às vésperas da Revolução. Segundo Rousseau observa no romance A nova Heloísa: "eu começo a sentir a embriaguez a que essa vida agitada e tumultuosa me condena. Com tal

${ }^{319}$ CANDIDO, Antonio. “A educação pela noite”. In: A educação pela noite e outros ensaios. São Paulo: Ática, 1987, p.17.

${ }^{320}$ AZEVEDO, Álvares de. "Literatura e civilização em Portugal”, 2000, p.743.

${ }^{321}$ Idem, idem, p.739.

${ }^{322}$ Idem, idem, p.743. 
quantidade de objetos desfilando diante de meus olhos, e vou ficando aturdido". ${ }^{323} \mathrm{O}$ aturdimento do sujeito, submetido a uma profusão de informações rápidas e desconexas, o leva a apreender a realidade de modo fantasmagórico e desordenado:

Essa atmosfera - de agitação e turbulência, aturdimento psíquico e embriaguez, expansão das possibilidades de experiência e destruição das barreiras morais e dos compromissos pessoais, autoexpansão e autodesordem, fantasmas na rua e na alma - é a atmosfera que dá origem à sensibilidade moderna. $^{324}$

Em uma estrofe citada na primeira parte do presente capítulo, o narrador de $O$ poema do frade fala da recusa de Jônatas em encarar a realidade violenta, "espelho de lodo ensanguentado". O jovem poeta libertino mantém-se em estado de embriaguez e turvação, "Como em nevoento mar perdida vela,/ Nos vapores do vinho assombreado/ Preferia das noites na demência/ Boiar (como um cadáver!) na existência!". ${ }^{325}$ A sensação de obscuridade e indefinição por ele experimentada é consonante com a imagem do momento histórico como "flutuação de luz e sombra no roxo crepuscular", descrita no ensaio "Fase Negra". A noção de que se vive "em dois mundos simultaneamente" 326 , "em que tudo se agita lugubremente, como por um enterro ou um nascer doloroso ${ }^{\text {327 }}$, é explorada especialmente no segundo capítulo de A Confissão de um filho do século, de Alfred de Musset, obra com a qual Azevedo parece dialogar não somente em "Fase Negra", mas também no ensaio "Alfredo de Musset: Jacques Rolla". Azevedo faz referência ao tempo enoitado repleto de ruínas e ao significado de Byron e Goethe como gênios por excelência, representantes da "poesia do século", conforme também se apresenta em A Confissão de um filho do século.

A sensação de viver em dois mundos simultâneos, de que fala Marshall Berman, é sintetizada de modo interessante no segundo capítulo de A Confissão de um Filho do Século. O "espírito do século" romântico é pautado pela indefinição, sendo representado como o "anjo do crepúsculo que não era nem a noite nem o dia", ou ainda "meio múmia e meio feto". Este estado intervalar e fantasmagórico segundo o qual "tudo o que era

\footnotetext{
323 ROUSSEAU, Jean-Jacques. A nova Heloísa apud. BERMAN, Marshall. "Modernidade: ontem, hoje e amanhã", in: Tudo que é sólido desmancha no ar: a aventura da modernidade. São Paulo: Companhia das Letras, 2007, p.27.

324 BERMAN, Marshall, idem, pp. 27-28.

325 AZEVEDO, Álvares de. O poema do frade, 2002 ,Canto Primeiro, estrofes XXIX e XXX, p.314.

326 BERMAN, Marshall, 2007, p. 26.

${ }^{327}$ AZEVEDO, Álvares de. "Literatura e civilização em Portugal”, 2000, p. 743.
} 
deixou de ser, tudo o que será não é ainda", gera um mal-estar generalizado chamado de "doença do século" no texto de Musset. Segundo o narrador da Confissão:

\begin{abstract}
Três elementos contribuíam para a vida que então se oferecia aos moços; atrás deles, um passado jamais destruído, agitando-se ainda sobre as próprias ruínas com todos os fósseis dos séculos do absolutismo; diante deles, a aurora de um imenso horizonte, os primeiros clarões do futuro; e, entre esses dois mundos... algo de semelhante ao oceano que separa o velho continente da jovem América, um não sei quê de vago e indeciso, um mar agitado e cheio de naufrágios atravessado de raro em raro por uma longínqua vela branca - ou por um navio soltando uma densa fumaça - numa palavra, o século presente, que separa o passado do futuro, sem ser um nem o outro e se parecendo com ambos ao mesmo tempo, e no qual, a cada passo dado, não se sabe se se marcha sobre uma semente ou sobre uma ruína. ${ }^{328}$
\end{abstract}

O entre-lugar no qual encontravam-se os românticos convive com as ruínas dos “séculos de absolutismo". Diante de Napoleão caíram "não somente a majestade, mas também a religião, a nobreza, a onipotência divina e humana". ${ }^{329}$ No entanto, essas lacunas não são preenchidas com algo novo e satisfatório, gerando a postura de luto pela fé irremediavelmente perdida, e fazem com que o narrador da Confissão insista bastante na ideia de que "perdemos o que os consolava",330, sem ganhar nada que pudesse substituí-lo. Os temas da "morte de Deus" e do niilismo de que fala Marshall Berman em seu estudo sobre a modernidade reverberam no texto de Musset. Tanto é assim que são constantes as imagens da morte, do sudário, do desmoronamento, das ruínas e do silêncio em sua obra. $\mathrm{O}$ poeta francês atribui à assimilação das ideias alemãs e inglesas de Goethe e Byron, respectivamente, o predomínio da tristeza, da ironia, da negação e do niilismo que caracterizam a poesia do século de modo geral, lançada ao "abismo da dúvida universal”.

Álvares de Azevedo incorpora a discussão sobre Goethe, Byron e o "espírito do século" no ensaio "Alfredo de Musset: Jacques Rolla". Os dois escritores citados por Azevedo são comparados ao deus latino Jano, possuidor de duas faces. Essa capacidade de apresentar os extremos da realidade é apontada como marca essencial do gênio, que oscila entre a fé e a descrença. ${ }^{331}$ Neste ensaio, Azevedo descreve a passagem do século XVIII para o XIX como a grande era de materialismo e ceticismo, marcada pelo "cataclismo" da Revolução Francesa. O tempo "enoitado, incerto de tendências", é resultado de uma "época de turvação", de difícil apreensão para o entendimento. Cada

\footnotetext{
${ }^{328}$ MUSSET, Alfred de. A Confissão de um Filho do Século. São Paulo: Editora Escala, sem data, p.12.

${ }^{329}$ Idem, idem, p. 13.

${ }^{330}$ Idem, idem, p. 19.

${ }^{331}$ AZEVEDO, Álvares de. “Alfred de Musset: Jacques Rolla”, 2000, pp. 678-679.
} 
época, continua Álvares de Azevedo, encontra o seu gênio, responsável por sintetizar a inclinação geral das multidões dispersas: "Cada século, na expressão de Magnin, tem de buscar nova língua e novos símbolos, novas fórmulas. A missão dos poetas é a poesia do século". O grande gênio dos tempos contemporâneos seria, a seus olhos, Lord Byron:

Os poemas de Byron são o espelho daquela época toda. Quando uma filosofia inteira estabelecia o axioma do ceticismo, e quando a população dormia esquecida de Deus sobre os túmulos vazios de seus reis - quando a cruz se estalara no frontispício das catedrais, e a fronte lívida e ebúrnea dos crucifixos se despedaçara nas lájeas do templo profanado - não era de espanto que a poesia viesse entoar o cântico dos funerais da crença no cadáver da religião. ${ }^{332}$

O poema narrativo Childe Harold, de Lord Byron, é chamado por Azevedo de Ilíada contemporânea, por sintetizar a expressão máxima do espírito atual:

E por isso, assim como a Ilíada é o transunto das eras da Grécia heroica - o Childe, com toda a amargura fria da desesperança, é o tipo do século XVIII, que morreu debruçando-se, numa última blasfêmia, sobre o berço do século novo, e inoculando-lhe no beijo da agonia a lepra de um cepticismo que, como o pomo da ciência, tem a seiva vivaz e longa que não há desarreigá-lo do peito. $^{333}$

O tema da falência da fé atravessa $O$ poema do frade, e justifica a epígrafe principal deste livro; ela faz referência a uma passagem da peça Don Juan (1665), de Molière, na qual a personagem-título define a sua descrença religiosa da seguinte maneira: "Eu acredito que dois e dois são quatro, Leporello, e que quatro e quatro são oito". ${ }^{334} \mathrm{O}$ ato terceiro, de onde foi extraída a citação, é particularmente dedicado ao tema do ateísmo de Don Juan. Numa das cenas, o fidalgo espanhol induz um eremita faminto a proclamar uma blasfêmia em troca de dinheiro. O caráter da personagem sedutora, ateia, libertina e hipócrita é constantemente criticado por seu criado Leporello (Sganarelle), que a alerta constantemente sobre o "excesso de discurso e de estudo, que levam Don Juan às inverdades e pecados do ateísmo e da luxúria". ${ }^{335}$ Don Juan adota conscientemente a máscara da "personagem do homem de bem" perto do desfecho da peça, e leva às últimas consequências o seu prazer em mentir e manipular. Seu demonismo está ligado à busca do saber baseado na ciência e no mérito individual, sem

\footnotetext{
332 Idem, idem, p.702.

${ }^{333}$ Idem, idem, idem.

334 MOLIÉRE. Don Juan. São Paulo: Hedra, 2006, p.63.

335 DIAFÉRIA, Celina. "Apresentação". In: MOLIËRE, op. cit, p. 04.
} 
as superstições da tradição, à maneira da figura do Doutor Fausto. No entanto, o antiherói de Molière sucumbe arrastado ao inferno, levado pelo espectro do Comendador.

Não há epopeia possível sem "o enthusiasmo pelo heroismo, a crença na vida sobrenatural” ${ }^{336}$, conforme Alexandre Herculano explica; não basta que o poeta épico demonstre esses sentimentos, "é preciso que achem echo entre os contemporâneos; que o sentir comum vá de acordo com o seu." É necessário que haja uma unidade geral de espírito, chamada pelo escritor português de "lei da harmonia entre o inspirado e a multidão". Este contexto é característico das chamadas "idades heróicas", que marcam o gênesis da civilização; tempo no qual o "crente falava a crentes". Os povos jovens, no auge de suas forças, geram as "epopéas verdadeiramente originaes”. A natural perfeição da poesia antiga não se confunde com as medidas frias e refinadas das épocas mais civilizadas, com suas "nações transformadas, polidas, argumentadoras, voluptuosas, incrédulas da velha Europa". ${ }^{337} \mathrm{O}$ neoclassicismo mantém as formas poéticas tradicionais, todavia divorciadas da crença no heroísmo divino, o que as torna um corpo vazio, sem espírito:

Nada disto [do espírito da poesia antiga] sentimos á leitura dos poemas épicos de epochas mais civilisadas. É que alli o poeta de crer e de pensar heroico falava solemnemente a homens do mesmo crer e pensar; aqui o poeta incredulo teve feito fabulas para incredulos. Alli a idéa dominava a fórma; a fórma era escrava, aqui a fórma domina a idéa; a fórma é mais que senhora; é, bem dizer, tudo. 338

O tempo contemporâneo não é marcado pelo "grandioso solemne e o crer profundo das gerações virgens", mas pela razão e pelo "filosofismo", que "olha para tudo o que é heróico e sobre-humano com frio desdem de indifferença e do scepticismo". ${ }^{339}$ Herculano lembra que os grandes poetas contemporâneos procuraram outras alternativas formais, cientes da falência da epopeia no contexto atual: "Nenhum dos summos poetas contemporâneos, Goethe, Byron, Manzoni, Lamartine, Garret, etc., tentou, que eu saiba, a epopéa. É que os seus altíssimos instinctos poéticos lhes revelavam que o commettimento seria mais que árduo, seria impossível”.

No ensaio denominado "Lucano", Álvares de Azevedo reflete sobre o problema do cultivo de formas estanques e a questão do mito na modernidade. Ele procura

\footnotetext{
${ }^{336}$ HERCULANO, Alexandre. "Alexandre Herculano crítico da Confederação", in: RAEDERS, Georges. Dom Pedro II e os sábios franceses. Rio de Janeiro: Atlântica Editora, 1944, p.202.

337 Idem, idem, p. 205.

338 Idem, idem, p. 203.

${ }^{339}$ Idem, idem , p. 204.
} 
destacar a multiplicidade das diversas composições do gênero épico em uma perspectiva histórica, comparando Homero, Tasso e Camões. A beleza plástica e estatuária da poesia homérica coincide, segundo Azevedo, com a beleza do corpo e a virilidade dos guerreiros mitológicos nela cantados, expressões do entusiasmo e força da infância da civilização ocidental. Já as epopeias de Tasso e de Camões marcam a substituição dos mitos pagãos pela crença cristã. Conforme Azevedo assinala, Camões não tematizou uma época de puro auge de sua civilização, mas pôde vislumbrar também a sua decadência. Nesse sentido, para ele Os Lusíadas é uma espécie de poema misto, condicionado por suas variantes históricas, conjugando as concepções temporais distintas do mito e da História.

O objeto de análise principal de Azevedo neste ensaio é poema épico Farsália, do romano Lucano. Por meio dele, poeta brasileiro defende a mescla entre o mito e a crônica histórica, e afirma o anacronismo de exigir fé do autor na época turbulenta em que este vivera, contemporânea à queda do império romano: “O tempo dele [de Lucano] era uma época singular. A voz fatídica do deus Pã clamara nas tênebras do mar Sículo — “os deuses morreram!” — e a geração descrida dos velhos pagãos se mergulhava nas ondas letárgicas da saturnal bacante". ${ }^{340}$ Para Álvares de Azevedo, a presença de mitos na Farsália é uma impossibilidade e um anacronismo:

A epopéia da Farsália não podia nem devia deslumbrar aos relâmpagos do Olimpo. Perdendo o mito, desembridando-se da fábula helênica, ganhava em verdade, porventura em unidade de ação o que não sei se perdia em grandeza - porque a verdade o é também: - não sei o que haja mais sublime que o sublime histórico.

E também, depois da poesia heleno-latina era impossível acordar aqueles colossos do paganismo com brilhantismo homérico - não só porque Homero viera primeiro, e porque fora o gênio maior da antiguidade; mas também porque Homero cria, e Lucano, é decadência descrida de Roma, não cria - e a poesia da religião é a fé. ${ }^{341}$

O julgamento da epopeia de Lucano segundo as regras fixas e eternas da Poética de Aristóteles é, segundo Álvares de Azevedo, inadequado, uma vez que é necessário reivindicar a historicidade das formas e gêneros neste caso:

Assim, pois, não há julgar a epopéia de Lucano pela Poética Aristotélica. A Poética, como todas as leis, deve variar com as suas condições de existência, com suas mudanças de relações. Leis irrevogáveis - eis uma utopia muito

\footnotetext{
${ }^{340}$ AZEVEDO, Álvares de. "Lucano". In: Obra completa, 2000, p. 659.

341 Idem, idem, p. 660.
} 
maior ainda na arte — um de cujos fins é o belo e o aperfeiçoamento do belo — do que na legislação — cujo fim é o justo e a realização do justo. ${ }^{342}$

Adiante, Azevedo reprova os críticos que riem "de uma crônica que fosse ao mesmo tempo um poema!". ${ }^{343}$ Aos olhos de Azevedo, o afastamento de Lucano dos modelos plasmados sobre o "ressaibo do céu grego" não é um defeito, mas um traço de sua originalidade e de sua profunda sintonia com as tendências do tempo. Os gêneros poéticos não são modelos perfeitos e acabados, mas formas em devir, em constante mutação. Pode-se observar que Álvares de Azevedo demonstra especial atenção aos períodos de crise das diferentes civilizações em seus estudos literários. Ele pinta a Revolução Francesa com imagens apocalípticas; a Roma de Lucano arde nas chamas de Nero; a cidade de Lisboa, outrora rainha, é descrita como uma prostituta moribunda, escrava, no "decaído das estátuas marmóreas", entre sangue, mortuárias e o frenesi das “turbas ardentes". A Roma de Lucano é similar a Lisboa de Bocage, apresentada em “Literatura e civilização em Portugal”. Para Azevedo, são nos momentos de crise que o poeta busca novas formas para abarcar a "poesia do século": "A epopeia, isto é, o sublime da história clama por seu evocador - como a amante por seu poeta. A epopeia a não ser um anacronismo seria um absurdo num tempo de marasmo". ${ }^{344} \mathrm{O}$ gênio moderno aflora em meio à convulsão social e a indeterminação de ideias.

\section{Complexo de Épico ${ }^{345}$}

Como discutiu-se ao longo deste capítulo, escritores como Álvares de Azevedo e Alexandre Herculano discorreram sobre a impossibilidade da epopeia em uma sociedade descrente, fragmentada e esvaziada pelas trocas mercadológicas. $\mathrm{O}$

\footnotetext{
${ }^{342}$ Idem, idem. João Adolfo Hansen lembra que a Farsália, juntamente com a Henríada, de Voltaire, recebeu críticas de Hegel, por tematizarem conflitos internos de um único Estado em guerra. De acordo com Hansen, "Na guerra, é a nação inteira que se põe em movimento estimulada a agir, pois trata de defender a totalidade da vertente natural de seu caráter natural pressuposta no idealismo do filósofo, evidenciando-a no herói representativo, que sempre surge movido por uma finalidade concreta". Aos olhos de Hegel, a Farsália e a Henríada são "guerras civis que dividem a totalidade de um povo, não de guerras entre totalidades", ou seja, favorecem a fragmentação em detrimento da unidade. HANSEN, João Adolfo. "Notas sobre o gênero épico". In: VÁRIOS. Épicos. Organização de Ivan Teixeira. São Paulo: Edusp/ Imprensa Oficial, 2008, p.40. Alexandre Herculano também critica a Farsália em sua carta de análise de A confederação dos tamoios. Para ele, a obra de Lucano pertence a uma época artificializada, na qual a poesia se torna "apenas formal". Cf. HERCULANO, 1944, p.203.

${ }^{343}$ AZEVEDO, Álvares de. "Lucano", 2000, p. 661.

${ }^{344}$ Idem, idem, p. 658.

${ }^{345}$ Expressão emprestada da música homônima de Tom Zé.
} 
nivelamento de todos os valores a uma reprodutibilidade prosaica destoa da exigência de elevação sobre-humana que o ideal de heroísmo antigo implica. Álvares de Azevedo caracteriza os tempos modernos como uma longa noite turbulenta e apocalíptica, onde vigoram o vício, a decadência e a corrupção de todos os valores. Todavia, tentativas de composição de epopeias e a concepções de literatura como instrumento a serviço da virtude e da fé religiosa continuaram a vigorar ao longo do século XIX, em especial no indianismo brasileiro.

No ensaio $O$ romantismo no Brasil, Antonio Candido identifica no indianismo o insistente projeto de composição de uma epopeia nacional. A publicação oficial de $A$ confederação dos tamoios, patrocinada pelo Imperador D. Pedro II, em 1856, visava "ser a grande demonstração de validade do tema indígena". ${ }^{346} \mathrm{O}$ país de passado colonizado buscava, após a sua Independência, construir uma mitologia nacional. A conquista da prestigiosa forma da epopeia era uma ambição política, pois simbolizava a definição de um novo "lugar cultural" perante as demais nações do Ocidente, sobretudo europeias, dotadas de uma longa tradição que remonta à Antiguidade. ${ }^{347} \mathrm{O}$ nacionalismo local buscou se aliar a certos padrões clássicos, passíveis de conferir o "verniz de nobreza" e o "ar de Ilustração", adequados às suas motivações políticas. Nesse sentido, a suposta epopeia de Gonçalves de Magalhães revela "uma forma literária extemporânea e anacrônica, todavia ideologicamente válida e eficiente aos propósitos do autor, de seu grupo e de um certo projeto literário brasileiro". ${ }^{348}$

Não só A confederação dos tamoios apostou na exploração do tema da ancestralidade indígena combinada ao mais elevado dentre os gêneros da tradição clássica. Candido cita, na mesma direção, a epopeia Colombo, composição em 40 cantos de Manuel de Araújo Porto-Alegre, apresentada dez anos depois de A confederação dos tamoios. Sousândrade, por sua vez, trabalhou na pseudoepopeia $O$ Guesa errante, entre os anos de 1866 a $1880^{349}$; em 1875, Fagundes Varela apresenta a “epopeia religiosa Anchieta ou o evangelho na selva". Paulo Franchetti também lembra outras tentativas

\footnotetext{
${ }^{346}$ CANDIDO, Antonio, O romantismo no Brasil. São Paulo: Humanitas, FFLCH, 2004, p.27.

347 CAMPATO JR, José Adalberto. “A Confederação de Magalhães: Epopeia e necessidade cultural”, In: VÁRIOS. Épicos. Organização de Ivan Teixeira. São Paulo: Edusp/ Imprensa Oficial, 2008, p. 836.

${ }^{348}$ Idem, idem, p. 840.

${ }^{349}$ O Guesa não é uma epopeia, conforme o próprio narrador diz em um de seus cantos, quando afirma que o heroísmo épico não é possível em meio às lágrimas da mãe-preta. A obra de Sousândrade também participa do debate sobre a validade do gênero ao decretar, assim como Álvares de Azevedo, Alexandre Herculano e muitos outros artistas e teóricos, a sua impossibilidade na modernidade. Seria interessante incluir as ideias de Sousândrade no debate desenvolvido nesta dissertação, porém, com o esgotamento do prazo, não foi possível dedicar-se a elas nesta oportunidade, que buscou centrar-se sobretudo no estudo do romantismo da primeira metade do século XIX brasileiro.
} 
semelhantes, como o poema em oitava rima A Independência do Brasil (1840-1855), de Teixeira e Sousa; o poema inacabado Os Timbiras, de Gonçalves Dias (iniciado em 1847 e publicado uma década depois); Os filhos de tupã (1863), outro poema épico indianista inacabado, dessa vez de José de Alencar. ${ }^{350}$ Como se vê, o projeto da epopeia brasileira atravessa o século XIX como um desafio estético obsessivo.

A estruturação em oitava rima e versos decassílabos, dispostos no esquema abababcc, da epopeia, é a mesma empregada em Os Lusíadas, de Luís Vaz de Camões; na Prosopopéia de Bento Teixeira; no Caramuru de Santa Rita Durão; em Os Escravos de Castro Alves; e também em Don Juan de Lord Byron, por exemplo. Em dialogo com toda essa tradição, os dois cantos iniciais de $O$ poema do frade adotam a mesma estrutura. $^{351}$ Álvares de Azevedo participou, à sua maneira, do debate sobre a (im)possibilidade de uma epopeia nacional no Brasil — , debate este que se prolongou para além de sua morte, ocorrida em 1852. Maneco viu apenas excertos de $A$ confederação dos tamoios na Revista Guanabara, uma vez que a obra só fora publicada na íntegra em 1856. Mas possivelmente teve contato direto com as discussões públicas sobre o projeto da grande epopeia nacional, das quais participava até mesmo o imperador. Como se disse, este financiara oficialmente $A$ confederação dos tamoios, na qual Gonçalves de Magalhães vinha trabalhando desde o final da década de 30. Vale lembrar que Magalhães foi professor de Álvares de Azevedo no Colégio Dom Pedro, no Rio de Janeiro.

Outro professor de Álvares de Azevedo, no mesmo colégio, e membro do Instituto Histórico e Geográfico Brasileiro tal como Gonçalves de Magalhães, foi Santiago Nunes Ribeiro, autor do ensaio "Da nacionalidade da literatura brasileira" (1843). Neste texto, Ribeiro aponta na religião e na moral as bases da nacionalidade local. Segundo ele, é patente a "influência civilizadora da religião" durante a história colonial do país; esta, Ribeiro destaca, "só desenvolvia os instintos nobres do homem

350 FRANCHETTI, Paulo. "O triunfo do romantismo: Indianismo e estilização épica em Gonçalves Dias”, In: VÁRIOS. Épicos. Organização de Ivan Teixeira. São Paulo: Edusp/ Imprensa Oficial, 2008, pp. 1100-1103. José de Alencar jamais o concluiu, jamais o publicou, transformando-o na prosa-poética Iracema.

351 A oitava rima foi tradicionalmente usada "na poesia épica ou epicizante", sobretudo durante o Renascimento e o neoclassicismo. Massaud Moisés inclui $O$ poema do frade na tradição da oitava rima no Brasil. Cf. MOISÉS, Massaud. Dicionário de termos literários. Cultrix, 2004, pp.329- 330. Tanto Massaud Moisés quanto João Adolfo Hansen destacam a metamorfose da tradição da oitava rima no século XIII italiano, quando ela começa ser empregada na poesia heroico-satírica. Cf. HANSEN, João Adolfo. "Forma romântica e psicologismo crítico", in: O belo e o disforme: Álvares de Azevedo e a ironia romântica. São Paulo: EDUSP/FAPESP, 1998, pp. 12-13. Lord Byron se inspira nos autores italianos para compor seus "poemas miscelâneas", ou "poemas herói-cômicos", como é o caso de Don Juan, que serve de epígrafe aos dois primeiros cantos de $O$ poema do frade. 
desses tempos, e comprimia, desarmava, moderava as paixões revoltosas, agressivas e sensuais". ${ }^{352}$ Segundo o autor, os grandes homens do passado local foram virtuosos "heróis do cristianismo", guiados pela devoção à mulher ideal, a Virgem Maria. Com base neste julgamento, Ribeiro afirma o seu desejo de evidenciar que "a piedade cristã, o amor da natureza, a admiração das ações heroicas, formam o caráter da musa do Brasil". ${ }^{353}$ Segundo ele, a natureza americana possuía a capacidade de elevar os instintos humanos, uma vez que "A virgem americana amava tudo quanto é vasto, grande, antigo e santo". ${ }^{354}$ Dentre os supostos "heróis do cristianismo", Ribeiro enaltece a figura do padre Santa Rita Durão, autor da epopeia Caramuru, "poesia religiosa, entusiástica e pitoresca". ${ }^{355}$ Ele destaca outros padres brasileiros que se dedicaram à poesia, como Anchieta, Caldas e São Carlos como exemplos de heróis nacionais.

$\mathrm{O}$ autor de "Da nacionalidade da literatura brasileira" acredita em uma identidade entre a natureza e o espírito, e "esta identidade absoluta é Deus". ${ }^{356}$ A grandiosa natureza brasileira é para os indianistas um indício do lugar de relevo que o país viria a ocupar na história do mundo; celebrar essa exuberância natural é para eles uma atitude patriótica. O "amor à Pátria” se confunde com "As verdades dogmáticas e a moral sublime do cristianismo". Gonçalves Dias manifesta posição semelhante a respeito da missão do poeta nacional: a poesia, segundo ele, "deve santificar as virtudes, e amaldiçoar os vícios. O poeta, empunhando a lira da Razão, cumpre-lhe vibrar as cordas eternas do Santo, do Justo e do Belo" ${ }^{357}$; deve cultivar a "decência" e combater toda forma de sensualismo, visto como inimigo da civilização. ${ }^{358}$ Assim como Gonçalves de Magalhães, Santiago Nunes Ribeiro também se posiciona de maneira contrária a uma literatura vinculada à filosofia sensualista, que sufocou o "sentimento religioso e estético".

Álvares de Azevedo polemiza com as teses de Ribeiro no ensaio "Literatura e civilização em Portugal", no qual refuta a política nacionalista como base para a nacionalidade literária. Ataca a lusofobia do grupo indianista ao negar a tese de Ribeiro

\footnotetext{
352 RIBEIRO, Santiago Nunes. "Da nacionalidade da literatura brasileira", in: Caminhos do pensamento crítico. Organização de Afrânio Coutinho. Rio de Janeiro: Pallas/ Instituto Nacional do Livro/ Ministério da Educação e da Cultura, 1980, vol. I, p. 65.

${ }^{353}$ Idem, idem, p.70.

${ }^{354}$ Idem, idem, p. 63.

355 Idem, idem, p.68.

${ }^{356}$ Idem, idem, p.43.

357 MAGALHÃES, Gonçalves de. "Lede". Caminhos do pensamento crítico, organização de Afrânio Coutinho. Rio de Janeiro: Pallas/ Instituto Nacional do Livro/ Ministério da Educação e da Cultura, 1980, vol. I, p. 39.

${ }^{358}$ Idem, idem, p.40.
} 
sobre a autonomia da língua portuguesa no Brasil. Seu antigo professor, por sua vez, critica o português Gama e Castro, que coloca em questão a autonomia literária brasileira com base no argumento de que a língua é a mesma usada na antiga metrópole, o que indicaria um único sistema literário. Azevedo questiona as teses de Santiago Nunes Ribeiro, da seguinte maneira:

[...] quanto a nosso muito humilde parecer, sem língua à parte não há literatura à parte. E (releve-se-nos dizê-lo em digressão) achamo-la por isso, senão ridícula, de mesquinha pequenez, essa lembrança do Sr. Santiago Nunes Ribeiro, já dantes apresentada pelo coletor das preciosidades poéticas do Parnaso Brasileiro. ${ }^{359}$

O autor de Macário sustenta que as literaturas brasileira e portuguesa não tiveram tempo suficiente para separarem-se completamente. Julga não ser possível afirmar que exista evidência de "brasileirismo" nos poetas árcades do século XVIII no Brasil:

[...] o poeta representante dessa época, Gonzaga, apesar de todos os lavores do Parnaso e do Plutarco do Dr. Pereira da Silva, não está muito claramente provado que fosse Brasileiro. Eis portanto: os usos eram os mesmos. Os homens de aquém-mar sentiam como os colonizadores. Fernandes Vieira e Amador Bueno eram cópia bela dos guerreiros das Índias. ${ }^{360}$

Nesse sentido, Azevedo coloca em questão a validade da produção dos poetas selecionados para figurarem no Parnaso Brasileiro, ou "Coleção das melhores poesias dos poetas do Brasil, tanto inéditas quanto já impressas" (1829 a 1831), de autoria do Cônego Januário da Cunha Barbosa, que elenca uma suposta tradição literária brasileira vigente já no período colonial. Álvares de Azevedo recusa sobretudo os autores de epopeia do neoclassicismo local, que julga inferiores a Camões ou a Bocage. A simples negação da herança lusitana é, para ele, um empobrecimento estético que em nada contribui para a nacionalidade literária brasileira, ainda em devir:

E demais, ignoro eu que lucro houvera - se ganha a demanda - em não querermos derramar nossa mão cheia de joias nesse cofre mais abundante da literatura pátria; por causa de Durão, não podermos chamar Camões nosso; por causa de quem? ... (de Alvarenga?) nos resignarmos a dizer estrangeiro o livro de sonetos de Bocage! ${ }^{361}$

\footnotetext{
${ }^{359}$ AZEVEDO, Álvares de. "Literatura e civilização em Portugal”, 2000, p. 715.

${ }^{360}$ Idem, idem, p. 716.

${ }^{361}$ Idem, idem, p.715.
} 
Álvares de Azevedo refuta a pretensão indianista de impor a sua estética como a saída exclusiva para a constituição da literatura nacional. Para ele, a riqueza das "letras pátrias" pode ser comparada a uma "praia tão derramada de pérolas e corais pelas marés que aí haviam passado no seu fluxo, das civilizações púnicas, greco-romanas, góticas e arábicas", e insiste na variedade de fontes na formação das literaturas de língua portuguesa: "a literatura de um povo era influída, como um líquido noutro, em sua civilização". ${ }^{362}$ A imagem das águas oceânicas em movimento conduz a sua poética ao ideal de uma literatura universal, distanciada da homogeneidade e da monotonia, enxergadas por ele na adequação aos modelos da literatura indianista. ${ }^{363}$ Antonio Candido comenta o desejo deste poeta por uma literatura universal e sem fronteiras:

[Azevedo] concebeu a literatura como espaço sem fronteira, uma espécie de comunhão universal dos talentos verdadeiros. Por isso, não apenas satirizou o indianismo como convenção vazia, mas negou a independência da literatura em relação à portuguesa, opondo-se deste modo a dois professores do seu colégio Pedro II do Rio de Janeiro: Gonçalves de Magalhães e Santiago Nunes Ribeiro. ${ }^{364}$

Conforme se discutiu acima, a variedade de literaturas estrangeiras, produzidas nas mais diversas épocas, é encarada por Azevedo como um rico repertório que deve ser criticamente apropriado. A originalidade do gênio romântico aflora na multiplicidade. Não se trata de romper com a tradição, mas sobretudo promover a sua revisão.

Ao desvincular a noção de nacionalidade literária da política nacionalista ligada ao indianismo, Azevedo contesta a "brasilidade" de escritores do período colonial (apontada por Santiago Nunes Ribeiro) em obras como O Uraguai e Caramuru, de José Basílio da Gama e do frei Santa Rita Durão, respectivamente: “José Basílio e Durão não foram tão poetas brasileiros como se pensa. Os heróis do Uraguai e do Caramuru eram portugueses. Não há nada nesses homens que ressumbre brasileirismo; nem sequer um brado de homem livre da colônia - nada". ${ }^{365}$ Para Azevedo, não basta tematizar a paisagem pitoresca como critério de nacionalidade; ele polemiza sobre o indianismo, não creditando a ele exclusividade na representação da nacionalidade poética:

\footnotetext{
${ }^{362}$ Idem, idem, 712.

${ }^{363}$ No segundo capítulo desta dissertação foi discutido o impulso pela variedade de fontes, temas e formas almejadas na poética de Álvares de Azevedo. A imagem sublime da vastidão do horizonte marítimo ligase ao desejo de transcender limites, sejam eles de pensamento ou entre os diferentes gêneros literários ou artes diversas.

${ }^{364}$ CANDIDO, Antonio. O romantismo no Brasil. São Paulo: Humanitas, FFLCH, 2004, p.50.

365 AZEVEDO, Álvares de, "Literatura e civilização em Portugal”, 2000, p.716.
} 
Doutra feita alongar-nos-emos mais a lazer por esta questão, e essa polêmica secundária que alguns poetas, e mais modernamente o Sr. Gonçalves Dias parecem ter indigitado: saber, que a nossa literatura deve ser aquilo que ele intitulou nas suas coleções poéticas - poesias americanas. Não negamos a nacionalidade desse gênero. Crie o poeta poemas índicos, como o Thalaba de Southey, reluza-se o bardo dos perfumes asiáticos como nas Orientais, Victor Hugo, na Noiva de Abidos, Byron, no Lallah-Rook, Thomas Moore; devaneie romances à europeia ou à china, que por isso não perderão sua nacionalidade literária os seus poemas. Nem trazemos a pleito o mérito dessas obras. Em outra parte enlear-nos-emos talvez essa questão. ${ }^{366}$

Conforme Álvares de Azevedo expõe, os elementos objetivos que codificam a estética indianista poderiam ser usados por um poeta estrangeiro, bem como um escritor local poderia se valer de outros exotismos (indiano, nórdico, chinês, etc) sem perder a sua nacionalidade literária. A sua posição se contrapõe a afirmações como estas, proferidas por Gonçalves de Magalhães e Santiago Nunes Ribeiro, respectivamente:

Não pretendemos que a esmo se louve tudo o que nos pertence, só porque é nosso; vaidade fora insuportável; mas porventura vós que consumistes vossa mocidade no estudo dos clássicos latinos e gregos, vós que ledes Racine, Voltaire, Camões ou Filento [sic] Elísio, e não cessais de admirá-los, muitas vezes mais por imitação que por própria crítica, dizei-me, apreciastes vós as belezas naturais de um Santa Rita Durão, de um Basílio da Gama, e de um Caldas? $?^{367}$

$\mathrm{Ou}$

Os tempos do heroísmo, as aventuras guerreiras, as conquistas formam o ciclo de um povo. José Basílio e Santa Rita Durão se apoderam deste ciclo e o cantam nos seus belos poemas. Na epopeia, o elemento narrativo, o lírico e o descritivo devem entrar em diversas proporções. ${ }^{368}$

Segundo Gonçalves de Magalhães, a dominação portuguesa impediu o desenvolvimento "natural" do Brasil. Ele associa o neoclassicismo e a mitologia à herança colonial, em oposição ao cristianismo, que ele julga uma manifestação autêntica do caráter nacional brasileiro. Para Santiago Nunes Ribeiro, as epopeias nacionais devem ser divinas (cristãs), "miltonianas". Com base em critérios como a religião cristã e a pintura da cor local, ele elenca poetas como Claudio Manoel da Costa, Botelho de Oliveira, Silva Alvarenga, Gonçalves de Magalhães, os padres Caldas e São Carlos, e José Bonifácio como representantes da poesia nacional.

\footnotetext{
${ }^{366}$ Idem, idem, p.715.

${ }^{367}$ MAGALHÃES, Gonçalves de. "Discurso sobre a História da Literatura do Brasil", 1980, vol. I, p.30.

${ }^{368}$ RIBEIRO, Santiago Nunes. "Da nacionalidade da literatura brasileira”, 1980, p.67.
} 
Apesar de estar vinculado à estética indianista, e propor uma literatura na qual o nacionalismo e a moral cristã estão profundamente relacionados, José de Alencar participa do debate sobre a epopeia nacional sugerindo caminhos diferentes daqueles indicados por Gonçalves de Magalhães e Santiago Nunes Ribeiro, por exemplo. Inicialmente, Alencar não escapou à tentação de compor um poema épico indianista, denominado Os Filhos de Tupã, chegando a escrever três cantos inteiros e parte de um quarto, de um total de doze cantos previstos. Alencar acreditava que do indianismo haveria de sair "o verdadeiro poema nacional". ${ }^{369}$ No entanto, o escritor desiste da empreitada, desiludido com a corrupção resultante da política imperial de coalizões, inicialmente apoiada por ele como uma saída para a superação do indiferentismo político e da "perda de princípios e diretrizes dos partidos que agiam apenas em função de interesses e necessidades do momento". ${ }^{370}$ A solução conciliatória adotada pelos partidos em oposição foi responsável por promover "a prostituição política de uma época". ${ }^{371}$ Segundo Vagner Camilo assinala, para um escritor como Alencar, que acreditava que "as letras devem ter o mesmo destino que a política" ${ }^{372}$, justificava-se o abandono do projeto da épica, uma vez que o entusiasmo e o otimismo perante a realidade que o gênero implica eram incompatíveis com o espírito de Alencar, naquela altura "meio descrido das coisas, e mais dos homens" no contexto de uma "pátria entorpecida pela indiferença". 373

A corrupção, a decadência dos costumes, e a melancolia que o país desperta em Alencar não coadunam com o heroísmo, a fé e a unidade de espírito da epopeia. Pensando neste contexto é que Vagner Camilo aponta a gênese do romance em prosa poética Iracema (1865) como saída estética diretamente ligada ao "projeto naufragado do épico Os filhos de Tupã". ${ }^{374}$

A idealização da realidade brasileira também sucumbe à visão crítica que o romancista e historiador Alexandre Herculano manifesta em sua análise de $A$ confederação dos tamoios. Seu parecer fora encomendado pelo próprio imperador Dom Pedro II, mas este fato não impediu que Herculano emitisse uma avaliação negativa sobre a obra em questão, baseada na incompatibilidade entre o gênero da epopeia e as

\footnotetext{
${ }^{369}$ Idem, “Carta sobre Iracema, ao Dr. Jaguaribe”. In: Caminhos do pensamento crítico. Organização de Afrânio Coutinho. Rio de Janeiro: Pallas/ Instituto Nacional do Livro/ Ministério da Educação e da Cultura, 1980, vol, p.117.

${ }^{370}$ CAMILO, Vagner. "Mito e História em Iracema". In: Novos estudos, 78, jul. 2007, p. 182-183.

371 ALENCAR, José de. "Cartas de Erasmo” apud CAMILO, Vagner, 2007, p. 183.

372 Idem. "Cartas sobre A Confederação dos Tamoios", apud CAMILO, Vagner, 2007, p. 184.

373 Idem. Prólogo de Iracema, apud CAMILO, Vagner, 2007, idem.

374 CAMILO, Vagner. "Mito e História em Iracema", 2007, p.170.
} 
contradições do mundo moderno. Este juízo o leva a afirmar o seguinte: "Duvido, e muito, de que nesta época o poema épico seja possível na Europa, e ainda mais que o seja na América" 375 , uma vez que o passado colonial brasileiro submetera os ameríndios à violência brutal e segregadora, baseada em prosaicos interesses mercantis: "Nem os vultos nem os factos que sobresahem no estabelecimento de colônias, que deviam em menos de tres seculos construir um opulento imperio, são assaz grandiosos para darem assumpto a uma epopéa, suppondo-a, alias, possível". Segundo ele, a postura genocida dos colonizadores é incompatível com a unidade ideal promovida pelo herói de epopeia. Mem de Sá e outras personagens celebradas em A confederação dos tamoios "foram chefes mais ou menos habeis, caracteres mais ou menos valorosos, mas estão longe do typo ideal das personagens épicas". 376

Ainda de acordo com Herculano, os índios em sua luta de resistência deveriam ser elevados a heróis do poema, e não os colonizadores portugueses. O que se mostra no poema de Magalhães, todavia, é a destruição e a marginalização dos nativos, rebaixados a escravos. Os índios ali descritos como supostos heróis são aqueles submetidos aos portugueses, traem os interesses coletivos da tribo e convertem-se ao catolicismo, abrindo mão de sua cultura. Tais atitudes revelam uma "completa negação da generosidade e do heroismo da epopéa", e a trama de Magalhães sinaliza antes a "desharmonia do espirito publico". 377

Herculano atesta a ausência de identidade entre os brasileiros e os indígenas contemporâneos, que vivem em sociedades paralelas. Diante disso, o historiador indaga se é possível creditar aos índios uma participação ativa na formação do caráter nacional brasileiro, e se este é original em relação à herança portuguesa. A postura de "guerra e extermínio" promoveu a apropriação material, sem uma assimilação do espírito indígena. ${ }^{378}$ Herculano desaprova a "frialdade, a falta de crer" no enredo de $A$ confederação dos tamoios; segundo ele, Magalhães não consegue revivar o passado heroico, por estar demasiadamente preso a "seu mister de poeta de gabinete de estudo"379; além disso, seu "poema revela o convencional e estudado em vez do

\footnotetext{
${ }^{375}$ HERCULANO, Alexandre. "Alexandre Herculano crítico da Confederação", in: RAEDERS, Georges. Dom Pedro II e os sábios franceses. Rio de Janeiro: Atlântica Editora, 1944, p. 201.

376 Idem, idem, p. 205.

377 Idem, idem, p. 206.

378 Herculano ainda lembra que é problemático falar da herança de uma possível poesia épica indígena, pois os indígenas brasileiros não se organizam segundo uma unidade nacional e uma identidade comum, sendo antes caracterizados pela pluralidade, pela autonomia, acentuadas pela fragmentação provocada pela violência da colonização.

${ }^{379}$ Idem, idem, p.209.
} 
inspirado e sentido". O resultado é calculado, mecânico, artificial, "sem fé no assumpto; sem fé nas sympathias do público por esse assumpto". O autor de Eurico, o presbítero, sustenta que a verdadeira poesia não é produto da civilização, mas uma manifestação espontânea, mais próxima do homem selvagem. Como uma saída formal possível para a epopeia de Gonçalves de Magalhães, Herculano sugere as soluções líricas encontradas por Gonçalves Dias nas “poesias americanas” ${ }^{380}$, e conclui o seguinte: “os Tamoyos não provaram falta de talento, nem talvez de genio; provaram apenas que o poeta se transviara por um errado caminho"; Herculano não cogita "esperar a verdadeira epopéa na Confederação dos Tamoios”, não somente devido a inabilidade estética de Magalhães, mas porque o mundo moderno, fragmentado, conflituoso e racionalista, não tem espaço para a unidade de crença e ação necessária à epopeia. Ao tentar realizá-la, "o talento e até o gênio luctariam debalde contra o impossível". 381

No mesmo ano em que é publicada, A confederação dos tamoios também sofre duras críticas em uma série de cartas compostas pelo poeta $I g$, pseudônimo adotado por José de Alencar. Ele desaprova o prosaísmo do estilo de Magalhães, que não corresponde à elevação pressuposta pela epopeia, bem como a sua debilidade em expressar a sublimidade da natureza brasileira ou de seus heróis de uma maneira original:

Se o poeta que intenta escrever uma epopeia não se sente com forças de levar a cabo essa obra difícil; se não tem bastante imaginação para reviver aquilo que já não existe, deve antes deixar dormir no esquecimento os fatos de sua pátria, do que expô-los à indiferença do presente.

Não se evocam as sombras heroicas do passado para tirar-lhe o prestígio da tradição; não se põe em cena um grande homem, seja ele missionário ou guerreiro para dar-lhe uma linguagem imprópria da alta missão que representa. $^{382}$

Em $O$ poema do frade as "épicas sombras do passado"383 foram irremediavelmente sepultadas sob as ruínas da Revolução Francesa. Tais sombras

\footnotetext{
380 Idem, idem, p. 207.

381 Idem, idem, p. 205.

382 ALENCAR, José de. "Cartas sobre a Confederação dos Tamoios". In: Caminhos do pensamento crítico. Organização de Afrânio Coutinho. Rio de Janeiro: Pallas/ Instituto Nacional do Livro/ Ministério da Educação e da Cultura, 1980, vol. I, p.100. Na avaliação de Alencar, o enredo da epopeia de Magalhães não respeita o princípio da ação e regras da epopeia, parecendo construir uma ligação acidental entre os acontecimentos. Essa trivialidade de assuntos conduzidos como se não fossem extraordinários se afasta da grandeza exigida pelo assunto. Segundo ele, o épico de Magalhães tem muito de cômico; este teria arrancado "do pó e das ruínas do passado esses bustos nacionais para amesquinhálos e fazê-los descer do pedestal em que a nossa história os colocou”, cf. p. 102.

${ }^{383}$ AZEVEDO, Álvares de. "O poema do frade", 2002, Canto Primeiro, p.344.
} 
movem-se no tempo presente apenas enquanto fantasmas. A tematização do tempo decadente e corrupto, no qual o sujeito se coloca em conflito com a realidade circundante e consigo próprio, leva Álvares de Azevedo a cantar a prostituta Consuelo, sublime alegoria de uma poesia também rebaixada e venal. Seu narrador, caracterizado como um frade obscuro e isolado, e o libertino Jônatas, como poeta marginalizado, não correspondem à imagem heroica do "grande homem, seja ele missionário e guerreiro" épicos, de que Alencar fala acima. Tendo em vista as frequentes tentativas de composição de epopeia nas mãos de escritores ligados à vida eclesiástica no Brasil colonial e imperial (Anchieta, Vieira, Durão, Caldas, etc), e a concepção indianista de literatura como instrumento de virtude moral e fé cristã, o restante deste capítulo buscará discutir a caracterização do narrador do poema alvaresiano em estudo como frade isolado e libertino, no contexto do debate sobre a epopeia nacional no romantismo brasileiro.

\section{Sextilhas, oitavas e frades}

Ao longo desta dissertação, buscou-se discutir a falsa promessa de uma epopeia em $O$ poema do frade, por meio da apropriação e dissolução da estrutura deste gênero. Desta maneira, o modo como o narrador do poema implode a forma do prólogo tradicional em seu longo poema narrativo e se vale de versos decassílabos distribuídos em oitava rima, atesta a sua proposta de diálogo com a tradição da epopeia. No entanto, vale lembrar que somente os dois primeiros cantos de $O$ poema do frade estão estruturados desta maneira; os últimos três, por sua vez, são compostos em sextilhas. Pensando nisso, a questão que se coloca é identificar a tradição com a qual Azevedo pretende dialogar por meio delas, e se existe um sentido alegórico na "troca das oitavas

p'la sextilha", conforme é anunciado no Canto Terceiro de $O$ poema do frade. ${ }^{384}$ Em outras palavras, ao longo da obra em estudo, muito se fala da falência do gênero da epopeia na modernidade; o uso da sextilha, por sua vez, poderia sugerir uma alternativa para a poesia, ou mesmo problematizaria o fracasso de uma outra tradição literária?

${ }^{384}$ Idem, idem, p.326. 
A fortuna crítica de Álvares de Azevedo dedicou-se na maioria das vezes a comentar o caso da oitava rima. Dentre as poucas hipóteses sobre o emprego da sextilha, Antonio Candido sugere a seguinte:

[...] como se sabe, Byron adotou no Don Juan a oitava rima, a exemplo do seu modelo confesso, Pulci; em Namouna, Musset utilizou uma estrofe de seis versos, com duas rimas alternadas. N'O Poema do Frade, composto sob a inspiração de ambos, mas particularmente do segundo, Álvares de Azevedo - como que reunindo as suas duas grandes admirações - emprega a oitava rima nos cantos I e II, e nos III e IV à sextilha com três rimas em ordem variável. ${ }^{385}$

O possível diálogo de Álvares de Azevedo com a poética de Musset em $O$ poema do frade pode ser percebido sobretudo por meio da apropriação e variação dos modelos das personagens existentes no poema francês Jacques Rolla. Rolla é poeta libertino como Jônatas; Marion é uma jovem prostituta, à maneira de Consuelo. A cena do encontro entre o casal, preludiando a noite de suicídio do herói, é incorporada explicitamente no Canto Segundo da obra alvaresiana em questão. ${ }^{386}$ Os modelos do poeta libertino e da sublime prostituta como exemplares alegóricos de uma realidade conturbada, que a tudo reduz ao mercado, são longamente comentados por Álvares de Azevedo no ensaio dedicado à análise do poema Jacques Rolla, conforme fora discutido mais acima neste capítulo. O dilema do herói entre o amor e o suicídio, bem como o encontro entre ele e a sublime Marion, misto de anjo infantil e prostituta, são largamente explorados por Azevedo em seu ensaio. ${ }^{387}$

A hipótese sobre a ligação entre os modelos encontrados na poética de Musset e os temas desenvolvidos em $O$ poema do frade é pertinente, ainda mais ao considerar-se a semelhança da atmosfera apocalíptica e arruinada desencadeada pela Revolução Francesa descrita no segundo capítulo de A Confissão de um Filho do Século, de Musset, bastante similar àquela representada em $O$ poema do frade e outros ensaios de Azevedo, como "Fase Negra" (parte de "Literatura e civilização em Portugal”), ou ainda "Da descrença em Byron, Shelley, Voltaire, Musset", última parte do ensaio "Alfredo de Musset: Jacques Rolla”. Além disso, existe uma possibilidade desses títulos de

\footnotetext{
${ }^{385}$ CANDIDO, Antonio. Formação da literatura brasileira: momentos decisivos. 7. ed., Belo Horizonte: Itatiaia, 1993, cf. nota de rodapé na página 160.

${ }^{386}$ Namouna, citada por Antonio Candido, serve de epígrafe ao capítulo $2^{\circ}$ de $O$ livro de Fra Gondicário, por exemplo, além de ser constantemente mencionada no ensaio de Álvares de Azevedo sobre Jacques Rolla.

${ }^{387}$ AZEVEDO, Álvares de. “Alfred de Musset: Jacques Rolla”. In: Obra completa, 2000, cf. em especial as pp 680-700.
} 
Álvares de Azevedo, citados neste parágrafo, haverem sido compostos em uma mesma época. Em uma carta de sua autoria, datada de 01/03/1850, Álvares de Azevedo comenta suas novas produções com o amigo Luís Antônio da Silva Nunes:

\begin{abstract}
Não tenho passado ocioso estas férias, antes bem trabalhadas de leitura tenho-as levado. Nesse pouco espaço de três meses escrevi um romance de duzentas e tantas páginas; dois poemas, um em cinco e o outro em dois cantos; uma análise do Jacques Rolla de Musset; e uns estudos literários sobre a marcha simultânea da civilização e poesia em Portugal, bastante volumosos; um fragmento de poema em linguagem muito antiga, mais difícil de entender que as Sextilhas de Frei Antão, noutro gosto porém, mais ao jeito do Th. Rowley, de Chatterton. ${ }^{388}$
\end{abstract}

Azevedo menciona, dentre as produções citadas, um poema em cinco cantos ( $O$ poema do frade?) e a análise sobre Jacques Rolla, bem como "Literatura e civilização em Portugal", comentados mais acima. Por fim, Azevedo refere-se com mais detalhes a uma obra escrita em linguagem arcaica, chamada por ele de "fragmento de poema" (seria O livro de Fra Gondicário?), que, segundo o poeta, pretende ser "mais difícil de entender que as Sextilhas de Frei Antão" ${ }^{\text {389 }}$, poema narrativo em estilo medievalista composto por Gonçalves Dias. Conforme Azevedo indica, por meio da obra fragmentária em questão, ele pretende dialogar com a tradição medievalista, e cita ainda Thomas Chatterton, embora não especifique de que maneira isso se daria. ${ }^{390}$

Ao citar o texto de Gonçalves Dias, Álvares de Azevedo menciona uma obra composta em sextilhas, que, além disso, apresenta um narrador também caracterizado como frade e com um estilo de escrita profundamente digressivo, traços que o aproximam de seu narrador em $O$ poema do frade. Antes de confrontar o perfil desses dois frades-narradores, vale ressaltar que as Sextilhas de frei Antão e o debate sobre a moda do medievalismo romântico, cultivada, sobretudo, em Portugal, aparecem discutidos por Azevedo em seu ensaio "Literatura e Civilização em Portugal". Na passagem, Azevedo afirma que "só como exercícios eruditos de antiquaria" pode-se abordar a maioria das obras compostas neste estilo, tais como "em nossa literatura, o do Rapto por homizio do Sr. Rebelo da Silva - talvez o do D. Sebastião, o Encoberto do Sr. Abranches - o de alguns solaus do Sr. Serpa Pimental [sic] e A. P. da Cunha, e o

\footnotetext{
${ }^{388}$ AZEVEDO, Álvares de. "Correspondência”: in: Obras completas, 2000, pp. 822-823. 389 O grifo é meu.

390 Dois meses mais tarde, em 05 de maio de 1850, Álvares de Azevedo escreve o ensaio “Aldo, o rimador", que salienta o tema da angústia do poeta que precisa sobreviver ao mercado, é explorado e reduzido à miséria material e existencial. Este perfil é similar ao "caráter de poeta" que Azevedo vê em Rolla e desenvolve em Jônatas.
} 
das Sextilhas de frei Antão do nosso mais mavioso poeta brasileiro, o Sr. A. G. Dias". 391 Azevedo considera que, na maioria das vezes, a moda dos arcaísmos de fundo medievalista é "um grande defeito do século", responsável por promover o "sacrifício das ideias e da poesia, a um lavor pelo exprimir — belo sim, mas morto, da língua antiga; desse abandono da láurea de bardo pela glória de antiquário, pela imitação dos poemas de Chatterton, e da seita erudita de W. Scott. ${ }^{\text {"392 }}$ Ou ainda, quase com as mesmas palavras, insiste que: "Chatterton, sacrificou porventura o cintilar das ideias pela hirteza de um falar elaborado, e em lugar de inspirações de poesia, preferiu mostrar a sua ginástica de jogral, e veio dar-nos preleções de antiquaria no impulso de exageração da seita erudita de sir Walter Scott". 393

Porém, Vagner Camilo ressalta que Gonçalves Dias não tem a pretensão de fidelidade histórica rigorosa na linguagem usada em Sextilhas de Frei Antão, formulando a dicção arcaica usada no texto como produto de invenção e recriação poética. Camilo ressalta a necessidade de certo distanciamento das sugestões historicistas implicadas no estilo medievalista adotado, que funciona, antes, como uma espécie de cortina de fumaça destinada a encobrir a presença da ironia no discurso do narrador das Sextilhas. Camilo chama a atenção para o estilo de narração, repleto de digressões e intromissões de seu narrador pouco confiável, que espalha falsas informações em seu texto para desnortear o leitor. Todas essas características foram atribuídas também ao narrador cunhado por Álvares de Azevedo ao longo da presente análise de $O$ poema do frade, nesta dissertação. Tendo essas coincidências em vista, vale pensar se entre os frades de Azevedo e Gonçalves Dias há mais relações de similaridade do que de discordância.

\footnotetext{
391 Idem, “Alfred de Musset: Jacques Rolla”, 2000, p. 688.

392 Idem, idem. O poeta continua: "É isso desconhecer a missão de aperfeiçoamento da língua. A combinação dos elementos da dicção moderna com os da envelhecida, pode ser um progresso: a imitação servil do estilo dos primeiros séculos é um regresso. Portanto só como exercícios eruditos de antiquaria podemos olhar o estilo das Memórias de P. L. Courier, das Cem novelas de Balzac, das poesias do pseudo-Clotilde de Surville(...)”, p. 688. O autor de $O$ conde Lopo aproxima mais uma vez a obra de Gonçalves Dias do medievalismo de Chatterton em uma passagem do ensaio "Literatura e civilização em Portugal", ao comentar a moda dos arcaísmos na literatura romântica. Segundo Azevedo, Alexandre Herculano, Almeida Garrett, Antonio Feliciano de Castilho e Mendes Leal são exemplos de autores que "retemperam as ideias de hoje, no fogo das expressões dos mestres da língua", criando uma linguagem poética exótica, dotada de um certo "perfume de antiguidade". Na literatura portuguesa contemporânea, Álvares de Azevedo aponta a existência de uma "seita shakespeariana", vinculada a tendências arcaizantes, como o "seiscentismo do Sr. Mendes Leal", autor avaliado como monótono por Azevedo em "Literatura e civilização em Portugal".

393 Idem, in: "Literatura e civilização em Portugal", 2000, p. 719.
} 
Em carta endereçada a um amigo, Gonçalves Dias afirma haver escrito "um bom rimance em português arcaico — uma semelhança de Chatterton” ${ }^{\text {394 }}$. Nesta época, era de amplo conhecimento o caso da fraude literária do poeta britânico que, dos 12 aos 18 anos de idade, forjara baladas em inglês arcaico. Elas foram por ele atribuídas a um monge fictício, denominado Thomas Rowley, que teria vivido no século XV. Chatterton também forjara documentos falsos para embasar a suposta descoberta dos manuscritos. A constatação de sua fraude causou escândalo, e fez com que o jovem poeta caísse em desgraça, vindo a suicidar-se precocemente. Ao modo de Chatterton, Gonçalves Dias cunha um autor na figura de um religioso; no entanto, diferente do poeta inglês, Dias deixa explícita a sua autoria, procedimento que impediu em certa medida uma possível mistificação em torno da misteriosa figura de Antão. No prefácio a Segundos Cantos, Gonçalves Dias fornece ao leitor informações sobre o frei em questão, narrador de seu poema. O poeta maranhense afirma que se baseara em um frei histórico, descrito na História de São Domingos, composta pelo frei Luís de Sousa. ${ }^{395}$ No entanto, segundo Vagner Camilo, a referência bibliográfica não procede; Dias a manipula, fazendo uma personagem de ficção passar-se por uma figura histórica.

Como se percebe, o narrador Antão espalha falsas pistas que, de antemão, não serão cumpridas, informações contraditórias ${ }^{396}$, e compõe um prefácio "minuciosamente construído para desnortear o leitor". Tais características fazem lembrar em especial os procedimentos do narrador de $O$ poema do frade ao longo do Canto Primeiro, analisado no capítulo de abertura desta dissertação, no qual ele embaralha a linearidade do preâmbulo convencional de epopeia, prometendo narrar uma "Odisseia" que jamais se concretiza. Como se viu anteriormente, a função essencial do prólogo tradicional é introduzir o leitor com segurança na obra, mas isso é subvertido ao se valer do efeito de prolixidade e confusão no caso de $O$ poema do frade. Os dois narradores, tanto o cunhado por Azevedo quanto o de Gonçalves Dias apresentam outras similaridades. Além de serem caracterizados como frades irônicos e narradores pouco confiáveis, ambos mostram tendências libertinas. O narrador alvaresiano não esconde a atração que sente pela bela prostituta Consuelo, cuja visão o deleita de modo mais explícito no

394 CAMILO, Vagner. "Nos tempos de Antão": Considerações sobre as Sextilhas de Gonçalves Dias. Revista da USP, São Paulo, v. 40, 1998-1999, p.107.

${ }^{395} \mathrm{O}$ frei Luís de Sousa, que vivera em Portugal entre os séculos XVI e XVII, foi transformado em herói da peça teatral de Almeida Garrett.

396 O "sorrateiro" "Frei Antão de Santa Maria de Neiva" propõe a narração dos feitos de valentias lusas ocorridos em três reinados diferentes. Camilo destaca a "longevidade inverossímil da figura padresca criada pelo poeta": o frei se diz narrador-testemunha de acontecimentos ocorridos durante trezentos anos. CAMILO, Vagner, 1998-1999, p.112. 
Canto Quarto. ${ }^{397}$ Antão, diferentemente do frade-narrador de Álvares de Azevedo, procura dissimular a sua libido com a sustentação de um discurso virtuoso, em harmonia com as exigências da Igreja; no entanto acaba por desestabilizá-lo em algumas passagens, ao depor contra sua própria imagem. Contrariamente ao Santo Antão medieval, que resiste às tentações, o frei de Gonçalves Dias não consegue disfarçar completamente o seu desejo pela bela moura Gulnare, ainda que a mesma professe uma religião diferente da sua. Em outras palavras, a sua atração carnal sobrepõe a sua fé religiosa, abalando a idealização cristã típica dos poemas medievalistas. O caráter dissimulado de seu frei-poeta é evidenciado por Gonçalves Dias em outra carta enviada ao amigo Teófilo: "Estou com a mania de me meter a frade, ou ordenar-me padre, talvez que eu chegue a ser bispo com biocos de virtude postiça". 398

Ambos os frades-narradores apresentam tendência a intromissões constantes na ação, desviando a atenção das personagens para a maneira como constroem o texto ou para as suas opiniões pessoais. Esta característica, embora constante, é falsamente desmentida por eles, uma vez que o frade alvaresiano garante não almejar falar de si mesmo ("Não prometi por certo a biografia/ Do sublime cantor desta epopeia" ou ainda "não quero contar a minha vida"399); já Antão atribui a sua interferência na narrativa aos seus "achaques de velhice".

O discurso digressivo do narrador de $O$ poema do frade foi analisado com mais detalhes no segundo capítulo desta dissertação, no qual se destacou o conjunto de metáforas marítimas, etílicas e de movimento que auxiliam na instauração de um discurso miscelânico e flexível, capaz de abarcar a sua reflexão perambulante. No caso de Antão, o discurso apresenta um vínculo mais intenso com a estrutura de um enredo no estilo medievalista, pautado em personagens e suas peripécias; porém, trechos mais prolixos acabam por se instaurar em alguns momentos, nos quais surgem contradições que denunciam o perfil dissimulado do narrador encoberto pela máscara do frei virtuoso. Digressões e demais estratégias de rodeios retardam a ação e instauram a quebra de ilusão dramática, desviando a atenção do enredo para a construção formal do texto. A sintaxe truncada e o uso peculiar da pontuação, em certos trechos, causam ruídos, impedindo a fluência do discurso. Este não se desenvolve como se pudesse

\footnotetext{
${ }^{397}$ Esta questão será analisada no próximo capítulo desta dissertação.

398 DIAS, Gonçalves, apud CAMILO, Vagner, 1998-1999, p.105.

399 AZEVEDO, Álvares de. "O poema do frade", 2002, Canto Primeiro, p.315,
} 
movimentar-se por si só, procedimento que evidencia a mediação de um eu, engajado na construção ficcional:

\author{
Deixemos pois estas coisas; \\ Bem qu'eu não saiba fallar, \\ Senão com longos rodeios: \\ (Vem-me o séstro de pregar) \\ Quando me julgo no cabo, \\ Mais longe estou de acabar. ${ }^{400}$
}

Em resumo, o discurso de frei Antão, permeado de ironia, digressões, adiamentos e quebra de ilusão dramática faz pensar naquele empregado pelo enunciador de O poema do frade, de Álvares de Azevedo, ainda que este último radicalize o efeito de indeterminação e subjetivação de seu discurso, se comparado ao estilo empregado por Gonçalves Dias nas Sextilhas.

Segundo Vagner Camilo, o estilo da linguagem utilizada nas Sextilhas de frei Antão provocou estranhamento no público brasileiro na época em que fora lançada. No entanto, mais do que a dissimulação de seu narrador, com seu discurso digressivo e cheio de armadilhas, foi a sua dicção arcaísta com "sotaque lusitano" "401 que levantou polêmicas. O medievalismo explorado por Gonçalves Dias destoava do restante de sua produção já consagrada entre o público de língua portuguesa, que o elevava a expoente máximo das "poesias americanas" —, gênero celebrado como expressão maior da originalidade nacional, conforme se vê em seus Primeiros Cantos. ${ }^{402}$ Vale lembrar que Alexandre Herculano sugeria a Dom Pedro o modelo das "poesias americanas" de Gonçalves Dias como solução estética bem sucedida, em detrimento da tentativa de epopeia de Gonçalves de Magalhães, conforme fora discutido mais acima no presente capítulo. $^{403}$ Frente a isso, chama a atenção o fato de Gonçalves Dias sair de sua confortável posição de reconhecido expoente indianista para se aventurar com uma incômoda proposta de composição medievalista, com a tematização do reino português em luta contra os mouros. Ao se deslocar do modelo indianista, visto na época como exemplo de originalidade e orgulho nacional, e se dedicar ao medievalismo, identificado com o caráter português, as Sextilhas soavam como uma nota dissonante e bastante

\footnotetext{
${ }^{400}$ DIAS, Gonçalves. DIAS, Gonçalves. "Sextilhas de Frei Antão". In: Poesia e prosa completas. Organização de Alexei Bueno. Rio de Janeiro: Editora Nova Aguilar, 1998, p. 335, apud CAMILO, Vagner, 1998-1999, p. 112.

401 CAMILO, Vagner. "Nos tempos de Antão": Considerações sobre as Sextilhas de Gonçalves Dias, 1998-1999, p. 106.

402 Idem, idem, idem.

403 HERCULANO, Alexandre. "Alexandre Herculano crítico da Confederação", 1944, p.207.
} 
incômoda no contexto da política nacionalista local, que adotara a postura de forte sentimento antilusitano como forma de combater a memória de subordinação inglória no passado colonial. ${ }^{404}$ A pouca acolhida das Sextilhas de frei Antão no Brasil já era prevista por Dias no prefácio que acompanha a obra, inserida no fecho do volume dos "Segundos Cantos". 405

Segundo Vagner Camilo, ao se apropriar de um estilo identificado à herança lusitana, Gonçalves Dias mostra maturidade e afirma a sua liberdade estética para além dos limites do "zelo nacionalista", que insistia na negação da tradição literária portuguesa. ${ }^{406}$ Por outro lado, Dias assimila o modelo medievalista sem "total reverência", ao compor seu narrador calcado na "figura nostálgica, ranheta e tardonha de um frei não lá muito santo que, supondo louvar, acaba ironicamente por desmistificar e expor ao ridículo a idealização de todo um passado de glórias lusitano". ${ }^{407}$ Dessa maneira, Gonçalves Dias assinala a autonomia de sua postura artística em relação ao Brasil e a Portugal, ao mesmo tempo. Pode-se observar que tanto o indianismo quanto o medievalismo estruturam-se com base na idealização de um suposto caráter nacional, tendo sido apropriados pela política nacionalista em seus respectivos países.

Cada um à sua maneira, Gonçalves Dias e Álvares de Azevedo colocam em xeque o estabelecimento de modelos estéticos homogêneos e normatizadores. Mais do que narrar aventuras de suas personagens, as Sextilhas de frei Antão e O poema do frade dedicam-se a discutir questões estéticas que problematizam a realidade histórica do país, bem como a assimilação das formas tradicionais em tempos modernos. O espírito crítico que movimenta a ironia de seus frades-narradores busca revisar os gêneros antigos e contemporâneos, e superar os estreitos limites de uma literatura localista. A postura irreverente e lasciva de ambos os narradores problematiza a concepção do indianismo enquanto estética oficial do Império brasileiro, que buscou aliar a sua literatura à moral burguesa do trabalho e defendeu o utilitarismo da arte, buscando "na conduta irreprochável a prova mais cabal de sua legitimação". ${ }^{408} \mathrm{Em}$ um período no qual o

\footnotetext{
404 A "experimentação arcaizante" levada a cabo nas Sextilhas aproxima-se do estilo praticado pelo grupo “Trovador", ligado ao medievalismo coimbrão. Alexandre Herculano, Mendes Leal e Serpa Pimentel são os representantes desta tendência. Todos eles são recorrentemente citados em ensaios alvaresianos, especialmente em "Literatura e civilização em Portugal". A reflexão sobre a herança portuguesa por meio do medievalismo é importante na medida em que o impulso indianista era negá-lo, adotando o romantismo francês como modelo em seu lugar.

405 CAMILO, Vagner, 1998-1999, p. 108.

406 Idem, idem, p.113.

407 Idem, idem, idem.

408 A expressão é de Vagner Camilo.
} 
nascente país buscava afirmar o seu lugar político e cultural perante as demais civilizações, a experimentação poética e o riso irônico dos frades-narradores desestabilizam os anseios de progresso e virtude do patriotismo romântico, domesticado pelas convenções.

Com base na discussão sobre um possível diálogo entre $O$ poema do frade e as Sextilhas de frei Antão, vale discutir um pouco mais em que medida a suposta citação da segunda obra na primeira se daria por meio do emprego da organização estrófica em sextilhas. Em larga medida, a fortuna crítica de Álvares de Azevedo considera pertinente o diálogo do poeta com a tradição da epopeia em $O$ poema do frade, com base na utilização da oitava rima, versos decassílabos e o objetivo, não cumprido por seu narrador, de narrar uma "Odisseia". Ao substituir a oitava, de inspiração classicizante, pela sextilha no Canto Terceiro, ele, de modo análogo, inicia o diálogo com uma outra tradição literária. A sextilha, por sua vez, é um modelo estrófico de inspiração popular e medieval ${ }^{409}$, pertinente ao poema narrativo de Gonçalves Dias mencionado mais acima. Todavia, as Sextilhas de frei Antão são organizadas em redondilha menor, uma das formas medievais por excelência, ao passo que as sextilhas de $O$ poema do frade continuam a apresentar versos decassílabos, que, com o seu metro mais longo, permite expandir melhor conceitos e ideias, tendendo a ser lido em voz baixa. Já o metro menor e mais oralizante facilita a memorização. Novamente, em $O$ poema do frade, afirma-se o predomínio de formas mistas.

A multiplicidade de referências e formas coexistindo simultaneamente em $O$ poema do frade vai de encontro aos anseios exibidos no ensaio "Literatura e civilização em Portugal" acerca da natureza mista da nacionalidade literária; isto também leva a cogitar que Álvares de Azevedo pode se inserir no debate sobre a validade do medievalismo na literatura local, por meio do uso das sextilhas, o que não exclui a possibilidade desta forma estrófica fazer referência a outros modelos e tradições, não desautorizando também a proposta de Antonio Candido de que as sextilhas alvaresianas podem ser uma citação a elementos encontrados na poética de Alfredo de Musset, conforme se comentou mais acima. Ao propor a sextilha, de herança medieval, com escansão decassílaba, vinculada à tradição clássica, Álvares de Azevedo pode indicar que os debates sobre a validade dos modelos medievalista e indianista, tal como a

\footnotetext{
${ }^{409}$ Ivan Vilela lembra que a forma da sextilha foi uma contribuição árabe, trazida durante a invasão da Península Ibérica no século VIII, e assimilada depois no repentismo nordestino. VILELA, Ivan. "Na toada da viola”, in: REVISTA USP, São Paulo, n.64, dezembro/fevereiro 2004-2005, p. 77.
} 
discussão sobre a possibilidade ou não da epopeia na modernidade, são todas questões interligadas e pertinentes dentro de seu projeto de literatura universal.

Tendo essa ordem de questões em vista, vale insistir na discussão sobre a caracterização do narrador de $O$ poema do frade como uma persona religiosa. A análise da figura de um frade-poeta inserido em um tempo enoitado e apocalíptico auxilia a pensar a tensa relação entre tradição e modernidade na literatura romântica.

\section{Condenação ao repouso}

A insistência de Álvares de Azevedo na construção de narradores-frades é recorrente em sua poética. O livro de Fra Gondicário apresenta um narrador com vários pontos de contato em relação àquele encontrado em $O$ poema do frade. São ambos hedonistas, irônicos, poetas, inclinados à digressão e ao devaneio, relação esta já comentada no segundo capítulo desta dissertação. No entanto, o narrador de $O$ livro de Fra Gondicário se mostra comprometido com um modelo narrativo calcado em um enredo movido pela ação objetiva de personagens, ainda que marcadamente confuso e truncado. O poema do frade, por sua vez, rompe mais decididamente com o modelo mimético antigo, ao deslocar o foco da ação objetiva de personagens e se voltar mais explicitamente para a exploração dos humores e estados da alma do narrador. Essa radical guinada para dentro, com a instauração de um auditório interno pautado pela indeterminação e pela obscuridade do fluxo de pensamento, pode justificar a ambição de Álvares de Azevedo na citada carta de 01/03/1850, na qual ele dizia aspirar a um poema "mais difícil de entender que as sextilhas de frei Antão".

Péricles Eugênio da Silva Ramos destaca o trecho desta carta, na qual Azevedo cita a produção de um poema em cinco cantos e um "romance de duzentas e tantas páginas", que Ramos sugere talvez se tratar de O poema do frade e O livro de Fra Gondicário, respectivamente. O crítico destaca a intenção de Azevedo de compor uma obra "mais ao jeito do Th. Rowley, de Chatterton" sobre a exploração do modelo do narrador-frade Rowley na poética alvaresiana, que inclusive teria inspirado a composição de um suposto projeto poético maior intitulado $O$ Livro de Fra Maffio Sant'Orso, infelizmente perdido:

\footnotetext{
${ }^{410}$ AZEVEDO, Álvares de. Carta de 01/03/1850, in: In: AZEVEDO, Álvares de, 2002, p. 823.
} 
Nesse rol, o romance talvez seja (é suposição de Homero Pires, não a nossa) o Livro de Fra Gondicário, que Vieira Souto imaginava integrar O Livro de Fra Maffio de Sant'Orso, à vista da folha de rosto do caderno manuscrito de Álvares de Azevedo com o projeto ou índice da obra (...).

Quanto ao poema em cinco cantos, tem todo o jeito de ser $O$ Poema do Frade; o em dois cantos não parece ter sobrevivido, nem o fragmento de poema em linguagem muito antiga, ao jeito de Chatterton. ${ }^{411}$

Péricles Eugênio da Silva Ramos relata que o estudioso Luís Filipe Vieira Souto sinalizara a possibilidade de O poema do frade e O livro de Fra Gondicário integrarem o suposto projeto intitulado O Livro de Fra Maffio Sant'Orso:

[Luís Filipe Vieira Souto] afirmava possuir autógrafos do poeta que iriam praticamente reformar o poema [ $O$ conde Lopo]. Esses originais haviam estado com Silva Nunes, que os devolvera à mãe do poeta, e com o girar dos tempos vieram a ficar com Vieira Souto, que asseverava possuir, ainda, modificações do Poema do Frade, do punho de Álvares de Azevedo, e partes do Livro de Fra Gondicário, mais perfeitas que o borrão de propriedade da Biblioteca Nacional, porque eram uma versão retocada de 1849 . Vieira Souto, que tinha ainda as Cartas de Álvares de Azevedo, encadernadas por d. Maria Luísa Silveira da Mota e Azevedo, mãe do poeta, chegou a publicar em Studia, ano III, n. 3 (dezembro de 1952), epígrafes e partes do Livro de Fra Gondicário, até então inéditas. ${ }^{412}$

No entanto, Péricles Eugênio relata que Vieira Souto falecera antes de publicar esse material, perdido após a sua morte. Frente a essas questões, interessa a possibilidade de Azevedo unificar parte considerável de seus escritos literários com base na figura do frade-narrador. Os exemplos do fictício monge-poeta Rowley, forjado como um escritor histórico por Thomas Chatterton, e o irônico frei Antão, criado por Gonçalves Dias, mostram que a relação entre narradores não confiáveis e personas religiosas no romantismo eram frequentes. Em O poema do frade, de Azevedo, são citadas passagens de Jocelyn, de Lamartine, que conta com um jovem padre como narrador $^{413}$, além de dialogar, na abertura do Canto Terceiro, com a produção do frade português (real) Filinto Elísio, por meio da assimilação do princípio miscelânico da

\footnotetext{
${ }^{411}$ RAMOS, Péricles Eugênio da Silva. “Introdução”. In: AZEVEDO, Álvares de, 2002, pp. 26-27.

${ }^{412}$ Idem, idem, p.24.

413 No Canto Segundo, a prostituta Consuelo é comparada à amada de Jocelyn, Laurence. Há menções à obra lamartiniana também nos cantos Terceiro e Quinto de O poema do frade.
} 
"variação" estilística, relacionada à concepção do topos do Fiat Lux como expressão romântica do sublime.$^{414}$

Mais acima, no presente capítulo desta dissertação, foi citada uma passagem do ensaio de Santiago Nunes Ribeiro, na qual o estudioso enaltecia as figuras de padres dedicados à literatura no Brasil, como Santa Rita Durão, autor da epopeia Caramuru, o jesuíta Anchieta, padre Antonio Pereira de Sousa Caldas e frei Francisco de São Carlos. ${ }^{415}$ Antonio Candido lembra que muitos homens da igreja engajaram-se no projeto de fundação do romantismo brasileiro, tendo se dedicado diretamente ao projeto de composição de uma epopeia nacional e aliado-se à política de matriz nacionalista. São Carlos compôs a epopeia Assunção (1819), na qual figura um paraíso tropical, bem ao gosto indianista. ${ }^{416} \mathrm{O}$ cônego Januário da Cunha Barbosa é autor do poema épico Niterói, além de ser organizador da coletânea Parnaso Brasileiro (1829-1831). Nesta obra, ele trabalhou na fixação de um corpus exemplar de uma possível expressão de brasilidade, apontada por ele já em autores da época colonial. Este material, vale lembrar, fora bastante questionado por Álvares de Azevedo em "Literatura em civilização em Portugal", em seu debate contra a noção de "brasilidade" sustentada por Santiago Nunes Ribeiro.

A presença de poetas ligados à Igreja no romantismo brasileiro explica-se pelo monopólio cultural que a instituição ainda detinha em um país de analfabetos, com uma imprensa recente, e também pelo alinhamento do poder imperial com a moral cristã, sustentado pelo discurso de uma suposta unidade e harmonia social, que naturalizava as desigualdades e os conflitos históricos decorrentes, como resultados de uma vontade maior da providência divina. ${ }^{417}$ Vale lembrar que Santiago Nunes Ribeiro aponta os missionários cristãos do período colonial como os grandes heróis "brasileiros"418; ou

\footnotetext{
414 No segundo capítulo desta dissertação também foi mencionado o caso do "pároco de sucesso" Laurence Sterne, representante de uma literatura experimental e digressiva em A vida e as opiniões de Tristam Shandy. Ao longo dos séculos XVIII e XIX surgem famosos narradores caracterizados como frades ou monges, como é o caso de Medardus, o monge atormentado e demoníaco de Hoffmann em $\mathrm{Os}$ elixires do diabo, e o "monge amante das artes" de Herzensergießungen eines kunstliebenden Klosterbruders (Efusões do coração de um monge amante das artes), desenvolvido por Wilhelm Heinrich Wackenroder, no qual a religiosidade surge vinculada a experiência estética (Kunstreligion) e a uma crítica ao filisteísmo burguês, que baniu a magia e o mistério do mundo com seu prosaísmo racionalizante.

415 RIBEIRO, Santiago Nunes. "Da nacionalidade da literatura brasileira", in: Caminhos do pensamento crítico, 1980, vol. I, p.68.

${ }^{416}$ Segundo Candido, também o frei Francisco de Monte Alverne procurou conciliar patriotismo e religião em suas composições. Cf. CANDIDO, Antonio. O romantismo no Brasil, 2004, p.22.

417 Cilaine Alves Cunha discute a chamada política do ecletismo adotada pelo Brasil imperial em Entusiasmo indianista e ironia byroniana, Tese de doutorado. FFLCH/USP. São Paulo, 2000.

${ }^{418}$ RIBEIRO, Santiago Nunes, 1980, p.68.
} 
ainda, José de Alencar afirma existir uma identidade entre as figuras do missionário religioso e do guerreiro épico. ${ }^{419}$

Charles R. Boxer de fato salienta a indissolúvel relação entre a cruz e a espada existente, por exemplo, no período de expansão ibérica, ocorrido entre 1440 e 1770. Segundo ele, havia um apelo aventureiro na vocação missionária, levando seus clérigos a embrenharem-se nas selvas tropicais com vistas a promover a conversão em massa dos povos não cristianizados. Nesse processo, era recorrente o estabelecimento de missões em regiões de fronteira, que pacificavam e conquistavam os territórios, ampliando a zona colonizada. Elas agiam em "estreita cooperação" com os soldados ${ }^{420}$, a ponto de, muitas vezes, as figuras de ambos se confundirem, como atesta um ditado espanhol corrente na época: "fraile que fue soldado sale más acertado". 421

O "entusiasmo missionário" conjuga a disposição a pegar em armas e a vida "ascética, monástica e comunitária"422, a inclinação bélica em uma organização social estruturada segundo uma pretensa unidade coletiva, plasmada pela fé religiosa, de fato garantem as condições para o afloramento do espírito épico de que fala Alexandre Herculano em sua carta a Dom Pedro. ${ }^{423}$ A ideia de unidade épica coletiva pode ser ainda encontrada na influência que o púlpito desempenhava até o século XVIII, quando a palavra oral dos religiosos era ouvida pelas multidões. ${ }^{424}$ Sobretudo após as revoluções francesa e industrial, o que se vê, em contrapartida, é o isolamento cada vez maior do sujeito submetido à divisão do trabalho; o gênero romance aprofunda o insulamento e o silêncio dos leitores, dedicados a fruir a palavra escrita; a unidade coletiva pautada pela "inseparável relação entre cruz e coroa, trono e altar, religião e império"425 torna-se fantasma ou ruína após a Revolução Francesa, que separou o poder

419 ALENCAR, José de. Cf. ALENCAR, José de. "Cartas sobre a Confederação dos Tamoios". In: Caminhos do pensamento crítico, 1980, vol. I, p.100

${ }^{420}$ BOXER, Charles R. A Igreja Militante e a Expansão Ibérica: 1440-1770. São Paulo: Companhia das Letras, 2007, p.93.

${ }^{421}$ Idem, idem, p.147. Para ressaltar o caráter bélico dos frades, Boxer cita as palavras do vice-rei do México: "Em cada frade das Filipinas, o rei tem o equivalente a um capitão-mor e um exército inteiro", p.94.

422 Idem, idem, p. 86.

${ }^{423}$ HERCULANO, Alexandre. "Alexandre Herculano crítico da Confederação”, in: RAEDERS, Georges. Dom Pedro II e os sábios franceses, 1944, p. 202.

${ }^{424}$ BOXER, Charles R, 2007, p.100. No período estudado por Boxer, ele destaca na crença em uma unidade divina universal plasmada no Sebastianismo, no século XVII, um "movimento português messiânico e milenarista, segundo o qual o rei de Portugal estava predestinado a tornar-se líder de uma monarquia universal" (p.142). Portugal viria a ser o Quinto Império, pois "fora criado por Deus com a finalidade específica de difundir a religião católica pelo mundo inteiro" (p.97). Conforme Boxer ressalta, a pretensa universalidade almejada encobria uma projeção ultranacionalista sob o manto da religião (p.144).

425 Idem, idem, p. 97. 
do Estado do poder religioso. A fé em uma razão sobre-humana e absoluta é abalada pelo individualismo moderno, que traz consigo a fragmentação e a relatividade como critérios de apreensão da realidade.

Em um contexto de esvaziamento da fé religiosa e de ascensão de valores burgueses, a figura do frade perde em grande parte a grandeza de seu caráter missionário, ficando cada vez mais restrita aos espaços privados e burocráticos. Em $A$ Confissão de um filho do século, Alfred de Musset descreve as guerras napoleônicas como uma época na qual vigorou pela última vez o espírito épico, capaz de mover as multidões em torno de um único ideal, ainda que este fosse a liberdade revolucionária, e não mais a fé religiosa:

Durante as guerras do Império, quando maridos e irmãos se achavam na Alemanha, as mães inquietas puseram no mundo uma geração ardente, pálida, nervosa. Concebidos entre duas batalhas, educados nos colégios ao rufar dos tambores, milhares de meninos se entreolhavam, sombrios, distendendo os músculos entorpecidos. De vez em quando, manchados de sangue, os seus pais apareciam, levantavam-nos até o peito engalanado de ouro e, depois, pondo-os de novo no chão, tornavam a montar a cavalo. ${ }^{426}$

A geração nascida em meio às guerras napoleônicas viveu, segundo o narrador de A Confissão de um filho do século, como se só houvessem "cadáveres e semideuses" em seu horizonte; entretidos com a guerra, que dava sentido às suas vidas, não temiam a morte e muito menos o tédio. ${ }^{427}$ Todavia, a França acabou por ficar "viúva de César". Cessaram-se as batalhas. Os "filhos do Império e netos da Revolução" viram-se novamente às voltas com os fantasmas do Antigo Regime, personificados por nobres, padres e reis, que se acomodavam à nova realidade burocrática. A juventude, sem lugar e sem sentido, entregava-se ao fastio de uma existência previsível e estreita:

Um sentimento de inexprimível mal-estar começou a fermentar em todos os corações jovens. Condenados ao repouso pelos soberanos do mundo, entregues a bedéis de toda espécie, à ociosidade e ao enfado, os jovens viam distanciar-se as vagas escumantes contra as quais haviam preparado seus braços. Todos esses gladiadores untados de azeite sentiam no fundo da alma uma miséria insuportável. Os mais ricos tornaram-se libertinos; os de fortuna medíocre arranjaram um emprego e se resignaram à beca ou à farda; os mais pobres lançaram-se friamente no entusiasmo, nas grandes palavras, no medonho mar de ação sem fim. ${ }^{428}$

\footnotetext{
${ }^{426}$ MUSSET, Alfred de. A Confissão de um Filho do Século. São Paulo: Editora Escala, sem data, p.09.

${ }^{427}$ Idem, idem, p. 10 .

${ }^{428}$ Idem, idem, p. 14.
} 
A condenação ao repouso aludida no excerto acima os levava a sonhar com o retorno ao passado de glórias e aventuras, bem mais estimulante do que a realidade prosaica que se instaurou. Porém, o sonho era sufocado pelas limitações da realidade frustrante, que os impelia a seguir os caminhos retos, repetitivos e conformados ao cotidiano burguês:

Os jovens observavam tudo isso, pensando sempre que a sombra de César fosse desembaraçar em Cannes e soprar sobre essas larvas; o silêncio continuava sempre, e, no céu, só se via flutuar a palidez dos lírios. Quando os jovens falavam em glória, diziam-lhes: "Façam-se padres". Quando falavam de ambição: "Façam-se padres". De esperança, de amor, de força, de vida: "Façam-se padres! ${ }^{429}$

A figura religiosa, antes aventureira e missionária, reduz-se a uma prosaica carreira ajustada à estrutura social burguesa. ${ }^{430}$ A sua relação com o mundo luminoso e vasto das terras longínquas e misteriosas, que a epopeia inspirava, não existe mais. $\mathrm{O}$ traje escuro dos padres acaba por contaminar o cotidiano secular de inspiração vitoriana, como uma expressão de luto perante das ruínas do passado. As armaduras se despedaçam e a roupagem alegre e florida do neoclassicismo desaparece sob os trajes sisudos e escuros da burguesia:

Que ninguém se iluda: a roupa preta que trazem os homens do nosso tempo é um símbolo terrível; para chegar a isso, foi preciso que as armaduras caíssem aos pedaços e os bordados de flor em flor. Foi a razão humana que destruiu todas as ilusões: cobre-se de luto, para se consolar. ${ }^{431}$

A possibilidade de qualquer ideal coletivo morreu: A moça pura e singela vendese para comprar chapéus e vestidos; ${ }^{432}$ os homens, ou entregam-se à libertinagem, anestesiando-se da realidade com vinhos e cortesãs, ou tornam-se homens de negócios, que restringem a vida ao campo dos sentidos físicos, em detrimento de qualquer anseio espiritual maior. ${ }^{433} \mathrm{Em}$ A Confissão de um filho do século a literatura contemporânea é

\footnotetext{
429 Idem, idem, p. 11.

${ }^{430}$ A ideia do seminarista soturno faz pensar na figura de Bentinho, em Dom Casmurro, aliás mais um narrador não confiável. No romance machadiano insiste-se muito no prestígio que a carreira eclesiástica desfrutava no seio da família patriarcal e na sociedade burguesa; não era mau negócio.

431 Para mais detalhes sobre a relação entre a estética do luto e o vestuário no século XIX, cf. SCHMITT, Juliana. Mortes vitorianas: corpos, luto e vestuário. São Paulo: Alameda, 2010.

432 MUSSET, Alfred de. A Confissão de um filho do século, p 14.

${ }^{433} \mathrm{O}$ narrador de A Confissão de um filho do século descreve a sociedade europeia após as guerras imperiais da seguinte maneira: "Formaram-se, então, como que dois grupos. De um lado, os espíritos exaltados, sofredores, todas as almas expansivas que têm necessidade de infinito, curvaram a cabeça, choraram, envolveram-se de sonhos doentios, e só se viram frágeis caniços, num oceano de amargura. De outro lado, os homens de carne ficaram de pé, inflexíveis, no meio dos prazeres positivos, e só tiveram o
} 
“cadavérica e "infecta",434, expressão de uma sociedade na qual os valores do passado já morreram, mas ainda apodrecem expostos nas ruas, dentre as suas ruínas. A corrupção, a decadência, a libertinagem e o tempo enoitado mataram a possibilidade de glória e reconhecimento social, e instauraram o niilismo e o isolamento do sujeito, inclinado então sobre si mesmo. Neste sentido, a figura do frade como narrador sintetiza o conflito do homem moderno, destituído de sua ligação transcendente com a divindade. A posição deslocada e obscura do frade de Álvares de Azevedo assinala, mais uma vez, a impossibilidade da epopeia na modernidade. Nem o frade e nem o poeta, antes identificados com a figura do profeta, são ouvidos pela multidão entorpecida e ocupada com as necessidades do mundo material; a poesia refugia-se na interioridade do artista, que subjetiva o auditório e o internaliza. A imaginação e a fantasia são a força motriz dos devaneios e do sonho, contrapostos ao tédio da realidade circundante, esvaziada de qualquer expectativa de magia ou de maravilhoso.

cuidado de contar o dinheiro que possuíam. Soluços e gargalhadas, um vindo da alma, outra vinda do corpo" (p.16). A corrupção, a decadência moral e o abandono das aspirações espirituais levam a sociedade a uma concepção de prazer sensualista, prosaica, mundana: "Comer, beber e dormir - eis a vida." (p.17). Curiosamente, esta última sentença é praticamente idêntica àquela encontrada na caracterização de Jônatas, no Canto Primeiro de O poema do frade: "Amar, beber, dormir, eis o que amava" (Cf. AZEVEDO, 2002, p.315, estrofe XXXIII), entendendo-se o verbo "amar" em sua dimensão sexual apenas. A reificação de todos os valores e sentimentos, relegados à função de somente gerar lucro, leva a moça pura e singela descrita, em A Confissão de um filho do século, à "noite de orgia, no fundo do lupanar, pálida e macilenta, perdida para sempre, com a fome nos lábios e a prostituição no coração!"(p.15). A miséria física e existencial assinala a visão pessimista do "filho do século".

${ }^{434}$ MUSSET, Alfred de. A Confissão de um filho do século, p.16. 


\title{
CAPÍTULO IV
}

\section{Ecos do poeta solitário}

\author{
Foi-se minha visão. E resta agora \\ Aquela vaga sombra na parede \\ - Fantasma de carvão e pó cerúleo, \\ Tão vaga, tão extinta e fumarenta \\ Como de um sonho o recordar incerto. \\ Álvares de Azevedo, "Ideias Íntimas"
}

\section{A chama se apaga}

No Canto Terceiro de $O$ poema do frade, a imagem do charuto ocupa uma posição de destaque na estruturação do discurso do narrador. A sua fumaça etérea e ondulante é relacionada à poética do frade alvaresiano, inclinada a devaneios e digressões; os desenhos do fumo evanescente mimetizam a sua livre reflexão, ao modo de arabescos. As linhas abstratas e curvilíneas estimulam a imaginação, e são identificadas às "formas lascivas" de donzelas, simultaneamente puras e voluptuosas, que dançam em meio a visões oníricas, emolduradas pelo "delicioso véu" produzido pelo tabaco. ${ }^{436}$ A "trêmula nuvem azulada", que revela a "virgem vaporosa", é a única companhia do narrador em sua condição de isolamento social, pois o charuto surge descrito como a única lembrança guardada do "mundo prostituto". Para além do refúgio encontrado nas paredes do convento ("Do mundo ao lodo fui viver bem longe"437), capaz de proteger os anseios idealistas do frade-poeta, encontra-se também a realidade do "bardo febril e macilento", que entoa os "hinos de sangue ao porviléu corrupto":

$\mathrm{X}$

Cante o bardo febril e macilento

Hinos de sangue ao poviléu corrupto,

Embriague-se na dor do passamento,

Cubra a fronte de pó e traje luto:

\footnotetext{
${ }^{435}$ AZEVEDO, Álvares de. "Ideias Íntimas", in: "Lira dos vinte anos". Poesias completas; edição crítica de Péricles Eugênio da Silva Ramos; Iumna Maria Simon (org), Campinas, SP: editora da Unicamp, São Paulo: Imprensa Oficial do Estado, 2002, p. 155.

${ }^{436}$ Para mais detalhes sobre a relação entre o movimento da fumaça, o arabesco e a reflexão, cf. o segundo capítulo desta dissertação.

437 AZEVEDO, Álvares de. “O poema do frade”, in: Poesias completas, 2002, p.326.
} 
Que eu minha harpa votei ao esquecimento:

Só peço inspirações ao meu charuto!

Como se vê, o bardo moderno entoa cantos decadentes e dolorosos. O frade substitui a harpa clássica pelo prosaico charuto, eleito a sua paradoxal via de transcendência. $\mathrm{O}$ desejo de esquecimento é um tema constante nos últimos três cantos de O poema do frade; muitas vezes, esse anseio é relacionado ao passado de tormentos experimentado pelo frade ou por Jônatas em suas juventudes, desencadeador das posturas libertinas e descrentes de ambos perante o mundo. $\mathrm{O}$ entorpecimento causado pelo vinho, pelo sexo ou pelo "perfume aéreo" do tabaco é celebrado como uma doce fuga da realidade aterradora e desinteressante:

XII

E como é belo no perfume aéreo Sentir o morno suor do abatimento Pelas lânguidas faces orvalhar! Como é doce nas cismas do mistério Sentir como um alcion à flor do mar As lembranças boiar no esquecimento!

Por proporcionar esse "esquecimento", o charuto é celebrado pelo frade, que o idealiza e humaniza, tratando-o como um amigo confiável constante, ou ainda como uma virgem jamais profanada, a salvo das desilusões mundanas:

XVII

E o amor muita vez aos lábios mente: Tem cores de maçã - e dentro infecta, E cinza aos lábios deixa-nos somente!

Além o seio, o coração corrupto

Que desmentem os sonhos do poeta!

Só tu não mentes não, ó meu charuto!

\section{XVIII}

Só tu és sempre belo como a lua E sempre virginal e perfumado, És o lírio do céu nunca murchado! Como a virgem de amor, cândida e nua, Evaporas no aroma essa alma tua E tens um lábio nunca profanado!

\section{XIX}

Só tu não mentes, não! e tu somente, Na taça da ilusão não deixas lia! E quando a mesma realidade mente Quando a virgem, a fé, de noite e dia Veremos amanhã que ontem mentia, Inda contigo dormirei contente! 
Vagner Camilo confirma essa relação entre o tabaco e a tendência ao devaneio, responsável por fazer "o pensamento dissipar-se no ar com a fumaça"438; as atmosferas vaporosas e evanescentes estimulam um estado de sonho e fantasia poética de um eu que, "mesmo em estado de vigília", pode transformar assim "os elementos banais da vida cotidiana em poderosas utopias, reflexo imediato da repulsa romântica ao mundo dominado por valores materiais" ${ }^{439}$. A humanização do charuto reforça este anseio.

Porém, toda a elevação do prosaico objeto às alturas do sublime é acometida por um repentino movimento descendente, ainda no Canto Terceiro. O objeto bruscamente cai nas profundezas do mar, e tem apagada a sua chama. Esta queda é bastante significativa, pois desencadeia uma atmosfera ainda mais fúnebre e pessimista nos últimos três cantos do poema. Além disso, o episódio da queda do charuto está inserido na metade da obra, como se dividisse os cinco cantos de $O$ poema do frade em duas partes distintas. A "primeira parte" composta em oitava rima ainda mostra vínculos maiores com uma ação centrada nas personagens Jônatas e Consuelo e de certa maneira às reminiscências de um mundo épico. Com a queda do charuto no Canto Terceiro, morrem todas as esperanças e ideais do frade, até então metaforizados na doce fumaça do charuto, que o protegia do mundo hostil. Como se buscará mostrar neste capítulo, a partir desse episódio de desilusão instaura-se um discurso cada vez mais subjetivo, que abandona de modo mais explícito a ação objetiva e passa a movimentar-se, então, de acordo com o fluxo dos devaneios e digressões. Estes acentuam a presença do fradenarrador, cada vez mais isolado; a morte devora suas personagens e tinge a sua narrativa com uma melancolia profunda e inexprimível. Neste sentido, também é significativa a comparação do charuto caído no mar com a imagem de um cadáver:

\section{XXI}

Meu charuto caiu, ei-lo se esfria: Além nas ondas vi-o mergulhar, Como o sol no crepúsculo do dia, Como um cadáver arrojado ao mar! Misérrimo! só resta cinza fria! No céu da vida estrela a desmaiar!

\section{XXII}

Tua vida apagou-se e eu perdi-te! Vai, conta às ninfas o meu mal tamanho! Nos lábios de Netuno ou de Anfitrite

\footnotetext{
438 CAMILO, Vagner. Risos entre pares: poesia e humor românticos. São Paulo: Edusp, 1997, p.109.

439 SANTOS, Wellington de Almeida. "Álvares de Azevedo e a ironia romântica", in: Obra completa, BUENO, Alexei (org.) Rio de Janeiro: Nova Aguilar, 2000, pp.101.
} 
Descreve minha dor, minha agonia,

Meu intimo sofrer quando eu te via -

Como Safo - morrer tomando um banho.

XXIII

E vós bardos nutridos de amargura

Que de prantos banhais a lira santa,

Se ainda o peito não trazeis corrupto,

Vinde chorar a minha desventura

Que no frio pavor de mágoa tanta

Veio até apagar o meu charuto !

A frustração do poeta, bruscamente lançado à realidade de completa solidão, é sugerida nas imagens do "crepúsculo", da "cinza fria" e da "estrela a desmaiar". Como se viu no segundo capítulo desta dissertação, imagens ligadas ao fogo, como o vulcão, ligam-se às noções românticas de imaginação criadora e fantasia poética. O apagamento da chama do charuto no mar gelado sugere a impossibilidade da poesia, do sonho e do desejo na frieza da realidade estreita dominada pela burguesia. Em um primeiro momento o charuto recendente inspira a ode ao frade-poeta, mas ao ser destituído de chama e fumaça (de sonho, desejo, esperança, ideal) ele motiva a elegia dos últimos três cantos de $O$ poema do frade: "Vinde chorar a minha desventura/ Que no frio pavor de mágoa tanta/ Veio até apagar o meu charuto!". Vale notar o esforço desesperado do narrador ao tentar elevar mais uma vez, e de modo ainda mais desproporcional, o seu querido charuto que, destituído da fumaça evanescente, é rebaixado à sua condição ordinária de mero objeto inanimado; este é alçado à dignidade da literatura e dos mitos antigos, ligando a tragédia do narrador às figuras das ninfas, de Netuno, Anfitrite e Safo, todos relacionados a topos aquáticos na literatura grega e na tradição clássica de modo geral. Em outras palavras, a grandeza implicada nestas referências busca expressar a dimensão colossal do "íntimo sofrer" do narrador, ao ver seu charuto afundar com todas as suas últimas esperanças e ilusões.

Como se afirmou no parágrafo acima, o apagamento da chama do charuto desencadeia a elegia, com frequentes imagens ligadas à morte, solidão e ao sofrimento. A natureza definha nas imagens da palmeira murcha e da ave morta. A lâmpada não resiste à frieza do leito sepulcral:

XXIX

Ah! quando enfim a lâmpada apagou-se

Do leito sepulcral na pedra fria,

Quando a palmeira ao florescer murchou-se

$\mathrm{E}$ a ave d'ouro que do sol vivia 
Caiu morta na relva recendida,

Gotejante das lágrimas da vida!

\section{XXX}

E tudo se acabou! e terra escura, Cobriu-te a face roxa desbotada, E tu foste da cal na sepultura

Sufocar-te nas tênebras do nada, Agora sim virei - e solitário -

Na solidão chorar o teu fadário!

A destruição e o niilismo invadem com mais força os cantos finais de $O$ poema do frade. A morte simbólica do charuto desencadeia o extermínio do sonho do poeta. Como se afirmou mais acima, até mesmo suas personagens não resistem à violência e às contradições da realidade, e morrem a seguir. A figura do cadáver é constantemente aludida nestes cantos derradeiros, com frequentes alusões ao espaço do cemitério, discutido mais adiante neste capítulo.

O tema do extermínio sistemático das ilusões e ideais do poeta leva o narrador de $O$ poema do frade a compor, no Canto Quarto, uma pequena série de estrofes nas quais explora imagens paradoxais de uma reconfortadora e sensual figura de Madona, dotada de um coração insensível e cruel. As contradições e os conflitos, e não a harmonia e a unidade, estruturam as relações no mundo moderno, repleto de "lágrimas, beijos e ironias":

\section{XXII}

Escrevi o meu sonho. Nas estâncias, Há lágrimas, e beijos e ironias, Como de noite muda nas fragrâncias Perde-se um ai de ignotas agonias! Tudo é assim - no sonho o pesadelo, — Em almas de Madona quanto gelo!

XXIII

É assim o viver. Por noite bela Não durmas ao relento na janela Contemplando o luar e o mar dormente. Poderá apanhar-te de repente Fria constipação, febre amarela, Ou alguma prosaica dor num dente!

\section{XXIV}

Vai, coa mão sobre o peito macilento Curvado como um velho peregrino, Vai, tu que sofres, implorar - sedento Um remédio de amor a teu destino!... Um doutor sanará o teu tormento Com três chícaras ${ }^{400}$ d'óleo de rícino! ${ }^{441}$

440 Sic.

441 AZEVEDO, Álvares de. "O poema do frade”, in: Poesias completas, 2002, p. 355. 
Como se vê, todas as imagens partem de temas elevados, como a contemplação do mar e da lua, signos românticos da infinitude, ou apresentam o sujeito sofredor com a dignidade de um peregrino, para então desencadear em um sucessivo rebaixamento de expectativas e estilos. A elevação da alma entregue à visão da natureza grandiosa resulta na lembrança da limitação corporal do sujeito, vulnerável à doença e à dor banal de um dente, provocada pela friagem; o sofrimento existencial, na sextilha seguinte, é violentamente calado pelo gosto amargo da realidade, representado pela xícara de óleo de rícino prescrita pelo médico (figura esta vinculada à rotina de trabalho burguesa), na redução de todas as dores da alma humana a sintomas físicos passíveis de medicação.

Wellington de Almeida Santos comenta a relação do poeta com a imagem do charuto, e também com o mundo, em O poema do frade. De acordo com Santos, as elevadas expectativas de liberdade e autonomia do poeta idealista diante da realidade, ordenada pelo materialismo econômico, são continuamente frustradas, gerando melancolia e desilusão. O refúgio na fumaça do charuto consiste em uma precária tentativa de resistência à perda das ilusões remanescentes de um passado nostálgico, no qual o poeta ocupava uma posição de destaque, considerado então profeta e homem público; a fumaça tenta propiciar, ainda, a espera (fracassada) da mulher ideal, alegoria da poesia romântica:

\begin{abstract}
Ao reconhecimento da frustração segue-se o rebaixamento total das relações entre o poeta e o mundo. No paroxismo da desilusão, sintetiza, em O Poema do Frade, com melancolia, o saldo negativo de suas malogradas expectativas. A perda das ilusões chega ao limite máximo através da forte imagem do "mundo prostituto", no qual o único verdadeiro é o do prosaico charuto. ${ }^{442}$
\end{abstract}

Santos afirma que a "blague do amor ao charuto não é gratuita" em $O$ poema do frade, pois está assentada na mesma ideia de "quebra da ilusão" explorada na segunda parte de Lira dos vinte anos, que opõe "mundo real e imagem ideal", mostrando a sistemática frustração das expectativas do poeta. A ironia romântica alvaresiana coloca em ação "as antíteses denunciadoras do choque entre real e ideal" ${ }^{443}$, afastando a sua poesia da harmonia e da unidade da poesia classicizante.

Conforme fora comentado mais acima, neste capítulo, o narrador antropomorfiza o charuto, devota-lhe profundo carinho, a ponto de chamá-lo de "amigo", ou mesmo

\footnotetext{
${ }^{442}$ SANTOS, Wellington de Almeida, 2000, p.106.

${ }^{443}$ Idem, idem, pp. 106-107.
} 
"tu", e entrega-se ao luto ao perdê-lo. Durante a meditação do frade sobre as contradições da vida e o mistério da morte, ele acaba por tecer desdobramentos delirantes, tornando ambíguo o referente de seu discurso. Esse "tu" em dado momento é chamado de "poeta", e confunde-se com a personagem Jônatas ao longo das numerosas estrofes do Canto Terceiro. Esta ambiguidade coloca em questão os limites entre o plano do narrador e do narrado, embaralhando vida e ficção, autor e personagens. A relação do frade com Jônatas e Consuelo assume contornos imprecisos nos cantos derradeiros da obra, tornando também incertos os limites entre imaginação e realidade em seu discurso. Inicialmente, o frade-narrador manifesta o desejo de homenagear e conservar a memória de seu "desgraçado amigo" —, que nesta altura, aparentemente parece se tratar do charuto de que vinha falando. Embora o furor afetivo dedicado ao objeto soe pateticamente exagerado, como no trecho no qual se refere às "puras ilusões do teu passado", ele se justifica pelo significado do desespero e do desamparo sintetizados no episódio da perda de seu "amigo":

\section{XXXI}

Virei tecer de moribundas flores

A pálida coroa do finado,

Lembrá-los, reviver os teus ardores

E as puras ilusões do teu passado!

Quero chorar meu desgraçado amigo,

$\mathrm{Na}$ lousa tua inda sonhar contigo!

Ao charuto, ainda agregam-se insinuações acerca de uma figura feminina indefinida e de um amor frustrado vivenciado por esse "tu" —, chamado mais adiante, inclusive, de "poeta":

\footnotetext{
XXXIII

Poeta! eras feliz — a mão divina

Quando passa na fronte sublimada

Os seus lânguidos olhos ilumina,

E ante uma sombra de mulher amada

Revela os hinos, que murmura o vento,

E sussurra à donzela o sentimento!
}

Ainda que o sentido metafórico do charuto seja importante para representar a violenta desilusão do frade perante a realidade —, o que justificaria a sua relação passional com o mesmo - , atribuir uma vivência amorosa do objeto com uma figura feminina (que pouco a pouco torna-se mais concreta ao longo do Canto Terceiro), e além disso chamá-lo de poeta, ecoa um tanto estranho, por mais que o narrador tenha 
sido tomado por delírio e desespero. Seu desdobramento confuso desemboca em imagens relacionadas ao herói Jônatas, deixado em suspenso no poema desde o final do Canto Segundo. A personagem, que pretendia suicidar-se, surge já morta, em um trecho no qual o narrador busca mimetizar o seu esforço em evocar memórias dolorosas das profundezas de sua mente, que emergem à sua consciência tal como um corpo vindo do fundo do mar. As especulações do frade sobre a morte favorecem o seu devaneio, que se estende durante a maior parte do Canto Terceiro, instaurando uma atmosfera onírica e indefinida, que faz coincidir o movimento das ondas marítimas desenvolvidas nas metáforas utilizadas como representação de seu fluxo de pensamento. Inicialmente, a imagem do cadáver boiando no mar surge como mais uma dentre tantas figuras encadeadas nas sequências devaneantes do narrador, porém ganha materialidade e continuidade quando o mesmo fixa-se nela ao longo das estrofes seguintes:

\section{LXVIII}

Harmonias de amor!. . . é tarde ! é tarde !

Vejo a morte num peito que se engoia... Da saudade o chorar, que os olhos arde... E além um corpo que nas águas boia! Um cadáver! um resto corrompido Que até fora da mãe desconhecido!

\section{LXIX}

O cadáver na praia se estendia Enjeitado p'lo mar: — as roupas úmidas - O cabelo a correr de areia fria As faces roxas, - mãos geladas, túmidas Mais alvo ainda que Don Juan dormido, De fome, sede e frio embranquecido!

O uso do artigo indefinido "um" antes do substantivo "corpo", no quarto verso da primeira das duas sextilhas citadas acima, reforça a impressão de indeterminação na imagem do cadáver. Este ganha contornos mais definidos na estrofe seguinte, com as referências às "roupas úmidas", o cabelo, as "faces roxas, as "mãos geladas, túmidas", e à fome, a sede e o frio, que aludem à sua condição física, concreta, condicionada pelo mundo da necessidade. A seguir, o enunciador especula sobre os supostos sentimentos do defunto, privado naquele momento do consolo de uma amada. Durante a contemplação do corpo imóvel na praia, o frade levanta hipóteses metafísicas sobre a experiência de morte do jovem, especulando se a alma humana seria imortal e continuaria a sofrer, mesmo após o passamento: “Deve n'alma doer, deve ser duro/ Esse 
abandono ao pobre malfadado!....." 444 O narrador segue com suas reflexões sobre o mistério da morte, até interrompê-las momentaneamente nas últimas cinco estrofes do Canto Terceiro, nas quais encadeiam-se bruscos acontecimentos, condensados em um número escasso de sextilhas. Como é recorrente em $O$ poema do frade, o enorme espaço ocupado pelas digressões devaneantes, neste canto, estão em evidente desproporção com os acontecimentos objetivos envolvendo personagens. Nas estrofes finais do Canto Terceiro, uma outra personagem surge repentinamente, sendo responsável por desmentir a condição de abandono do cadáver:

\section{LXXVIII}

Alta noite porém: eu não sonhava... Achegava-se a luz de uma lanterna. E cândida mulher se debruçava. E nos lábios a voz chorava terna Em dorida canção, cortada e rouca Dizia à treva o padecer da louca!

LXXIX

A louca!... ao vê-lo aí enlouquecera Junto ao amante a mísera Consuelo: Das flores da restinga entretecera A coroa da fronte no cabelo. Ria, ria porém com dor tamanha! Como a onda do mar que os pés lhe banha.

\section{LXXX}

Pôs ao colo o cadáver: repassou-lhe Por sobre a fronte a mão que estremecia. E nos cansados braços embalou-lhe A cabeça qu'inda ontem lhe fervia... E cantava beijando os lábios dele... Coitada! adormeceu pensando nele!

\section{LXXXI}

Porque era morto aí o libertino Jônatas o cantor da vida impura, Não o posso explicar ao peregrino. Creio a morte porém caverna escura, Mais fria que o deserto cemitério Onde o corpo resvala no mistério.

Só então são identificadas as personagens de maneira explícita: a prostituta Consuelo vem ao resgate de Jônatas, "o cantor da vida impura", já morto. Embora o narrador mostre o desfecho da cena e nomeie as personagens, eliminando o mistério de suas identidades, ele se recusa a "explicar" ao leitor (terceiro verso, estrofe LXXXI) as circunstâncias que geraram a morte do herói e a loucura da moça. Para assegurar o

${ }^{444}$ AZEVEDO, Álvares de. "O poema do frade", 2002, Canto Terceiro, Estrofe LXXIV, p. 339. 
"mistério" da morte, ele concede algumas explicações, porém apenas parciais. O Canto Terceiro encerra-se abruptamente, com a alegação do frade de que não profanará o descanso do poeta libertino: "Não sacudo à mortalha o pó escuro". Sua preferência pelo luto silencioso sinaliza a limitação das palavras, incapazes de comportar o peso extremo da experiência da morte:

\section{LXXXII}

Sobre o túmulo pois os braços cruzo E dobro tiritando os meus joelhos! Não sacudo à mortalha o pó escuro E nem leio da campa nos espelhos... Da morte no fatal despenhadeiro Desfolho apenas uma flor sem cheiro!

Embora o narrador não apresente uma explicação clara acerca dos motivos que teriam levado Jônatas à morte, ele alude, ao longo do poema, ao projeto de suicídio da personagem. No Canto Terceiro, há insinuações sobre o desespero desencadeado pela impossibilidade amorosa, tema reforçado pela citação a Werther em uma de suas estrofes:

\section{XXXVII}

E que sonhos de amor que amou na vida!

Perguntai-o à estrela que divaga,

Ao vento na lagoa adormecida,

Ao círio que no túmulo se apaga,

Perguntai-o da insônia aos arrepios,

De Werther o suicida aos lábios frios!

É interessante observar que os "sonhos de amor" desdobram-se na imagem da estrela divagante, do vento sobre a lagoa, até desembocar, não por acaso, naquela do "círio que no túmulo se apaga", antecedendo, por sua vez, a menção ao suicídio do famoso herói de Goethe. Diante das questões desenvolvidas até aqui, pode-se observar que o episódio da queda do charuto nas águas funciona como um prelúdio ao suicídio do herói, confirmando então em um plano literal as imagens do "vórtice das águas do delírio" e do "afogar as ilusões da vida", espalhadas pelo narrador ao longo do Canto Terceiro: "Desgraçado! a insônia do martírio/ O cérebro lavoso delirou-te!/ E o vórtice das águas do delírio/ Das insônias da febre ao sol queimou-te!/ Foste afogar as ilusões da vida/ Na taça de mistério do suicida!". ${ }^{445}$

445 AZEVEDO, Álvares de. "O poema do frade", 2002, Canto Terceiro, p. 333. 
Como é recorrente em $O$ poema do frade, o assunto principal é adiado o máximo possível. O nome de Jônatas é proferido somente na penúltima estrofe do longo Canto Terceiro. Algumas sextilhas antes, na mesma cena, Consuelo surge para resgatar o corpo do poeta libertino, e o narrador assume um discurso que destoa do estilo digressivo e delirante que vinha adotando desde a passagem da queda do charuto, no início no mesmo canto, e afirma o seu estado de vigília e atenção: "eu não sonhava...". ${ }^{446} \mathrm{Em}$ outras cenas da narrativa, o frade parece inserir-se de maneira próxima das personagens, não como se fosse o autor da ação, mas como se testemunhasse os acontecimentos. No primeiro capítulo da presente dissertação, comenta-se a passagem na qual o pesadelo de Jônatas mescla-se ao estilo por vezes devaneante (ou mesmo delirante) do narrador: o frade afirma ter visto, ouvido ou sentido experiências vividas por Jônatas e Consuelo, sobretudo em situações nas quais os dois se encontram sozinhos, sem a possibilidade de qualquer outra testemunha.

A possibilidade de um narrador onisciente, contudo, torna-se menos plausível no decorrer dos cantos de $O$ poema do frade, levando-se em conta a insistência do narrador em afirmar-se testemunha de vivências determinantes no passado das personagens, e alegar dificuldades de memória. Estas nem sempre parecem ser mero produto de sua imaginação. A omissão das circunstâncias da morte de Jônatas e da loucura de Consuelo, bem como a sua dedicação ao luto do "desgraçado amigo", podem ser índices de sua proximidade com as personagens, e inclusive de uma suposta culpa ou participação no destino trágico de ambas.

A seguir, será analisada uma passagem do Canto Quarto, na qual o frade contempla a beleza de Consuelo imóvel, vencida pelo cansaço e pelo trauma da morte de Jônatas. Deve-se lembrar que no Canto Segundo, o herói libertino era quem contemplava a moça. A ação análoga do frade no Canto Quarto reforça a ideia de substituição desta última personagem pelo narrador: se no Canto Primeiro o enunciador afirmava, ironicamente, não pretender contar a sua vida, mas dedicar-se à narração de uma "Odisseia" centrada no herói Jônatas, o que se vê, em contrapartida, nos cantos finais da obra, é a realização de um poema cujo tema principal é a subjetividade do narrador, e não a ação de uma personagem distinta dele. Isso reforça a sugestão do título de sua obra: $O$ poema do frade.

${ }^{446}$ Idem, estr. LXXVIII, p.340, 


\section{Túmulos}

A loucura da personagem Consuelo é destacada pelo narrador na cena comentada mais acima, na qual a jovem prostituta, tomada pelo delírio, surge na praia e acolhe o cadáver de Jônatas. O estado de insanidade da garota manifesta-se nas estrofes finais do Canto Terceiro e continua em evidência por todo o Canto Quarto. Nesse trecho, com maior ênfase no quarto canto, o frade-narrador dedica-se a contemplar a beleza atormentada da jovem desvairada, entregue à agonia convulsa diante da "praia fria”. Esta visão desperta nele uma série de reminiscências vinculadas a outras figuras femininas da tradição literária, ligadas aos temas da loucura e da morte desencadeadas pela paixão contrariada. Há uma interessante comparação entre a heroína venal criada por Álvares de Azevedo e outros perfis femininos consagrados pela literatura ocidental, como Ofélia de Hamlet, Clorinda de Jerusalém Libertada e Haideia de Don Juan. A associação entre essas diferentes personagens visa ressaltar o contraste entre a prostituta Consuelo e essas demais beldades, ligadas, cada uma à sua maneira, a certa nobreza de resquícios épicos não mais compartilhada pela musa venal em $O$ poema do frade.

No final do Canto Terceiro, os sintomas da loucura de Consuelo evocam muito claramente os de Ofélia, de Hamlet: ambas cantam durante o delírio resultante de um trauma; estão em ambientes de inspiração aquática e tecem coroas de flores de inspiração fúnebre. Há uma visível intenção do narrador de $O$ poema do frade em inserir elementos da antológica cena shakesperiana em sua obra, como nos trechos seguintes, nos quais ressalta a combinação entre loucura e canto: "nos lábios a voz chorava terna/ Em dorida canção, cortada e rouca/ Dizia à treva o padecer da louca!”, ou ainda: "Pôs ao colo o cadáver (...) / E cantava beijando os lábios dele".

As referências a Ofélia na caracterização de Consuelo ainda podem ser observadas no início do Canto Quinto de O poema do frade. Na cena em questão, narrase o sepultamento de uma beldade, pautado pela costumeira indefinição no discurso do frade alvaresiano. Em nenhum momento profere-se explicitamente o nome de Consuelo, mas tendo-se em vista o seu estado de extrema agonia física e metal no final do Canto Quarto, bem como o seu trauma da morte de Jônatas no Canto Terceiro e a obsessão do narrador com o tema da solidão em que ele se encontra durante o Canto Quinto, pode-se supor que a bela que fenece, condenada à degradação, é mesmo Consuelo —, alegoria da arte venal em $O$ poema do frade. Como será discutido mais adiante neste capítulo, a morte do poeta libertino e do modelo de beleza prostituída encarnado na jovem são 
motivos fundamentais na reflexão de Álvares de Azevedo sobre a impossibilidade de heroísmo épico na modernidade e da posição deslocada do poeta. A revisão da tradição literária realizada pelo autor engloba não somente uma crítica aos modelos e gêneros do passado, mas também aos rumos da literatura contemporânea.

No Canto Quinto de O poema do frade, é retomada a célebre cena do sepultamento de Ofélia em Hamlet. No diálogo entre a passagem shakesperiana e aquela composta por Álvares de Azevedo, este último carrega nas tintas do pessimismo: se em Hamlet há dois coveiros que trabalham juntos e dialogam, em $O$ poema do frade somente um deles realiza o seu ofício, de modo que a sua solidão é ressaltada a todo momento pelo narrador alvaresiano. Se Ofélia é sepultada no cemitério real e velada por uma procissão, Consuelo é enterrada como indigente, tão solitária quanto o coveiro que momentaneamente se depara com a sua beleza transitória. Como procurarei ressaltar, há um contraste entre a condição nobre de Ofélia, que garante a preservação de sua memória e o seu sepultamento digno, e o anonimato da prostituta Consuelo, destituída de qualquer sentido épico. Neste sentido pode-se compreender a insistência do narrador de $O$ poema do frade em destacar a situação de abandono e solidão do "campo da morte" descrito no Canto Quinto, tomado pela "erva inculta" e pelo verme, que profana a beleza da donzela e a dignidade do ancião. Novamente, o tema do esquecimento é levantado pelo narrador. A memória, a "mais épica de todas as faculdades" 447 , torna-se insustentável nos tempos modernos, regidos pela pressa do tempo do relógio:

\section{II}

Era o campo da morte onde brota a erva inculta

Sobre o corpo do ancião e da donzela,

Aonde o verme a forma nívea insulta

E o mármore dos seios amarela!

E aonde ao apagar de uma memória

Dos amigos enterra-se a lembrança! ${ }^{448}$

A morte deixa de ser a entrada do sujeito na esfera da eternidade e do mito para se reduzir a um episódio rotineiro, como bem fica sugerido pela banalidade e pelo procedimento mecânico dos coveiros presentes em Hamlet e em $O$ poema do frade. $\mathrm{O}$ fato de um coveiro cantar durante o exercício de seu penoso trabalho, insensível à morte ao seu redor, revela a dissonância notada por Hamlet no comportamento automático do

${ }^{447}$ BENJAMIN, Walter. "O narrador: Considerações sobre a obra de Nikolai Leskov", in: Magia e técnica, arte e política: ensaios sobre literatura e história da cultura. 7. ed. São Paulo: Brasiliense, 1994 - Obras Escolhidas, vol I, p. 210.

${ }^{448}$ AZEVEDO, Álvares de. "O poema do frade", 2002, P. 351. 
trabalhador (que prepara o sepultamento da nobre beldade), e o sentido trágico da morte:

HAMLET: Esse camarada não tem consciência do trabalho que faz, cantando enquanto abre uma sepultura?

HORÁCIO: O costume transforma tudo em coisa natural. ${ }^{449}$

Totalmente sozinho em $O$ poema do frade, sem a companhia de outro coveiro, isento do olhar de outrem, o irônico e jovem trabalhador do "campo da morte" relativiza seus "monótonos sons da cantilena" com o "sarcasmo zombeteiro". Sua canção de teor lírico, entoada em "voz serena", contrasta com a situação e o local, mesclando o seu “canto de amor" às ressonâncias dolorosas e irônicas da atmosfera fúnebre:

VIII

Os monótonos sons da cantilena Corriam doces como essência pura: Era o canto de amor - a voz serena. Mas aí, junto ao lar da sepultura, Dessa boca nervosa na ironia, D'alma nos seios a canção doía! ${ }^{450}$

Tanto em Hamlet quanto em $O$ poema do frade a banalidade do ofício dos coveiros contrasta com o profundo senso filosófico que eles demonstram diante das contradições e fragilidades da existência humana em alguns momentos. Os dois coveiros em Hamlet debatem os privilégios dos nobres, lembrando que Ofélia tem a garantia de um enterro digno, a despeito de haver cometido suicídio - , circunstância que a privaria das honras fúnebres, conforme prevê a moral cristã. Sem um companheiro com quem possa exercer o diálogo, o coveiro de $O$ poema do frade é profundamente marcado por uma estruturação interna dialógica e irônica, a começar pela sua aparência e comportamento contraditórios de moço "mas já envelhecido", que "Cantava e ria" ao mesmo tempo. O automatismo de seu trabalho é quebrado por alguns instantes fugazes, no momento em que vislumbra uma beleza incomum dentre tantos cadáveres grotescos:

XI

Era um fosso que abria - eterno leito

${ }^{449}$ SHAKESPEARE, William. Hamlet; tradução de Millôr Fernandes. Porto Alegre: L\&PM, 2010, Ato $\mathrm{V}$, cena I, p.120.

${ }^{450}$ AZEVEDO, Álvares de. "O poema do frade", 2002, Canto Quinto, estrofe VIII, p. 352. 
A um cadáver de mais. Quando o sentiu

Profundo e longo — do caixão estreito

No sudário tomou um corpo frio...

Ia lançá-lo... As nuvens se entreabriram,

Frouxos os raios do luar sorriram...

\section{XII}

Deu no corpo o luar. Era alva imagem

Reflexo branco de mulher divina!

As trancas negras à noturna aragem

Tremiam como um lírio que se inclina!

Tão bela! parecia adormecida!. ..

Era o sono... porém não o da vida! ${ }^{451}$

Por um instante, uma beleza "divina" entra em consonância com toda a natureza ao redor: as nuvens se abrem e os raios de luar enchem de luz a noite escura. A atividade prosaica e repetitiva do coveiro abala-se diante de uma surpresa epifânica. Porém, tal como os vermes e a "erva inculta", presentes na abertura do Canto Quinto, o coveiro não hesita em profanar a "alva imagem", deixando-se tomar por "vil desejo". Após beijar longamente o cadáver, o jovem deixa-se tocar brevemente pela inconformidade diante da fugacidade da beleza, destinada a se corromper. Diferente do necrófilo Solfieri, que eterniza a beleza de sua musa cataléptica em uma estátua de mármore, o coveiro de $O$ poema do frade simplesmente depõe a sua bela defunta em sua sepultura, vira as costas e dá continuidade à sua rotina, como se nada extraordinário houvesse ocorrido:

\section{XV}

"Tão formosa e morrer!"... e murmurando

O coveiro deitou-a na jazida:

Encobriu-a de cal... e sussurrando

Da noite à sombra uma canção descrida,

Erguendo na mão pálida a lanterna

Foi da morte olvidar-se na taverna!

A sua "canção descrida" e o sistemático esquecimento, obtido pela embriaguez na taverna, conjugam o ceticismo perante a possibilidade do mito e do divino na rotina de trabalho repetitivo. Como se afirmou mais acima, a jovem prostituta de $O$ poema do frade recebe um enterro solitário, enquanto Ofélia é acompanhada pela procissão real, responsável por sepultá-la na tumba erguida como monumento à sua memória. À

\footnotetext{
${ }^{451}$ Idem, idem, estrofes XI e XII, p. 353.

${ }^{452}$ Idem, idem, Canto Quinto, Estrofe XV, p. 353-354. As duas linhas pontilhadas extras na sextilha em questão marcam a mudança de assunto do enunciador na estrofe seguinte.
} 
maneira dos muitos poetas pobres e marginais presentes na poética alvaresiana, Consuelo finda como indigente, fadada ao esquecimento. Seu falecimento ocorre em circunstâncias tão confusas e vagas quanto o de Jônatas. O Canto Quarto todo incide sobre a moça enlouquecida, abraçada ao cadáver do poeta libertino. Seu canto delirante não é transcrito, mas aludido de maneira indireta pelo frade. $\mathrm{O}$ narrador se entrega à contemplação da jovem agonizante que, vencida pelo cansaço, dorme nas areias do mar noturno. Tal como Jônatas no Canto Segundo, o frade divaga sobre os sentimentos da moça, procurando desvendar seus sonhos: "Que pensamento, que desejo incerto/ Que saudades e amor a palpitavam?". ${ }^{453} \mathrm{O}$ narrador não explica as causas que promoveram o estado ensandecido da jovem, mas dedica-se apenas a deleitar-se com a sublime imagem da garota, paralisada pela dor, como se ele buscasse prolongar a fruição sensual obtida nesta visão:

XVII

Ela dorme. Silêncio! ó noite bela! Fresco perfume só derrame o vento Nos cabelos da lânguida donzela! E da noite ao frescor o sangue lento Corra nas suas azuladas veias

Como a onda do mar sobre as areias!

\section{$(\ldots)$}

\section{XXI}

Sonhar-te, Consuelo, em minha noute, Em teus prantos, o peito suspiroso, E sentir que nos seios estalou-te Essa fibra gentil que acende o gozo, Que fala aos olhos, no hálito suspira, E nos transes do amor num beijo expira,

$$
\text { (...) }
$$

XXIII

Sentir-te no morrer volver sombria — Tateando o negro chão — os olhos baços.

Os olhos que a paixão de pranto enchia!

Ver-te depois, convulsa erguendo os braços, Ansiando no estertor, na praia fria

Arquejar e torcer-te de agonia! ${ }^{454}$

Há uma espécie de perversidade no olhar do frade-narrador, em certa medida similar ao do frei Antão, de Gonçalves Dias, aludido no capítulo anterior desta dissertação. O narrador gonçalvino não consegue disfarçar o seu olhar de cobiça pela

453 Idem, idem, Canto Quarto, p. 346.

454 Idem, idem, Canto Quarto, p. 347-348. 
moura Gulnare, e mostra-se excitado com o sofrimento da infiel, como se esse estado a tornasse, a seus olhos, ainda mais bela. ${ }^{455}$ Apesar de Consuelo ser apresentada como o par amoroso do herói Jônatas em $O$ poema do frade, o misterioso narrador desta obra manifesta abertamente o seu desejo pela jovem no Canto Quarto, quando o poeta libertino já está morto: “Sonhar-te, Consuelo, em minha noute,/ Em teus prantos, o peito suspiroso,/ E sentir que nos seios estalou-te/ Essa fibra gentil que acende o gozo,/ Que fala aos olhos, no hálito suspira,/ E nos transes de amor num beijo expira". 456

No Canto Terceiro, na digressão que precede o anúncio da morte de Jônatas por afogamento, o narrador faz uma afirmação que novamente embaralha os planos entre narrador e personagens:

\section{LIII}

E que sonhos, meu Deus! e que ventura!

E que vento de amores palpitava

$\mathrm{Na}$ escuma do batel a vaga pura

E lascivos suspiros the arrulhava!...

E em torno mar e céu - a noite é bela,

Nos meus braços a inanida donzela! $!^{457}$

O uso do pronome possessivo em meio a tantas imagens digressivas misturadas, em um trecho que mimetiza o discurso delirante, inicialmente pode não chamar a atenção a ponto de sugerir outras implicações na narrativa: teria o frade contribuído para a desgraça de Jônatas e Consuelo, e por isso se negaria a fornecer algumas informações sobre o enredo, simulando uma distância entre eles ao apresentá-los como personagens fictícias, fruto de sua imaginação? Ou ainda, dada a semelhança do perfil de Jônatas e o frade, ambos poetas e libertinos, seriam a mesma pessoa? Trata-se de um discurso indireto livre no qual as vozes de ambos se misturam? Tendo em vista a subjetivação radical da realidade proposta em algumas vertentes do romantismo, seria possível delimitar claramente os limites entre essas diferentes dimensões: vida e arte, realidade e imaginação? São questões que a obra em estudo pode suscitar.

No momento, vale retomar a análise do delírio e das condições de morte e sepultamente de Consuelo, visto que o narrador compara estes temas a outros análogos, presentes na tradição literária ocidental. Além de Ofélia, outra figura feminina ainda mais ligada a um mundo com resquícios épicos é confrontada com a pobre prostituta

${ }^{455}$ DIAS, Gonçalves. "As sextilhas de Frei Antão”. In: Poesia e prosa completas; organização Alexei Bueno. Rio de Janeiro: Editora Nova Aguilar, 1998.

${ }_{456}$ AZEVEDO, Álvares de. "O poema do frade", 2002, Canto Quarto, estrofe XXI, p. 347.

${ }^{457} \mathrm{O}$ grifo é meu. 
alvaresiana. No caso, a guerreira Clorinda, da epopeia Jerusalém Libertada, de Torquato Tasso. A referência surge no poema logo depois de um conjunto de estrofes centradas na agonia de Consuelo, no Canto Quarto. A citação ao poema de Tasso é lacunar e faz alusão ao instante de morte da guerreira pagã pelas mãos de Tancredo, guerreiro cristão por ela apaixonado:

XXIV

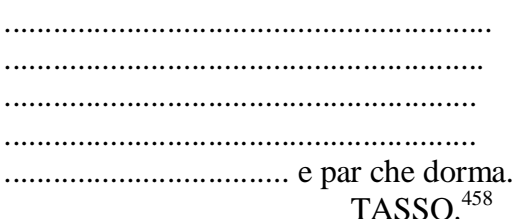

TASSO. ${ }^{458}$

A passagem original na epopeia de Tasso é a seguinte:

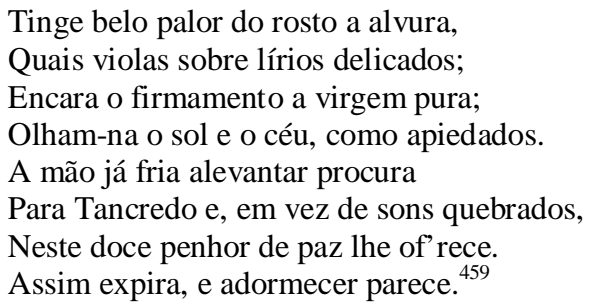

Ciente da iminência de sua morte, Clorinda, "a virgem pura" até então disfarçada de homem, revela a sua identidade para Tancredo, que posteriormente quase enlouquece. As últimas palavras da donzela guerreira são o pedido de batismo cristão. $\mathrm{Na}$ cena, Tancredo receia que a amada, integrante dos exércitos inimigos, fique insepulta, pois: "Nem quer deixá-la à sanha devorante/ Dos lobos, inda que infiel parece" ${ }^{460}$ O guerreiro cristão cuida do cadáver da amada como se fosse uma relíquia, protegendo-lhe da profanação: as "relíquias do corpo lindo e casto", "vos conservarei, restos amados". ${ }^{461}$ Clorinda morre como guerreira virgem e santa. Embora cercada das condições adversas e precárias do campo de batalha, recebe um túmulo erguido como monumento à sua memória. Junto ao pé de uma árvore frondosa, destinada a velar o seu

458 AZEVEDO, Álvares de. "O poema do frade", 2002, Canto Quarto, p. 348

459 TASSO, Torquato. Jerusalém Libertada. Rio de Janeiro: Topbooks, 1998, p. 400. A passagem original, citada por Azevedo, é: "D'um bel pallore há il bianco volto asperso,/ come a' gigli sarian miste viole,/ e gli occhi al cielo affisa, e in lei comverso/ sembra per la pietate il cielo e '1 sole;/ e la man nuda e fredda alzando verso/ il cavaliero in vece di parole/ gli dà pegno di pace. In questa forma/ passa la bela donna, e par che dorma”. Cf. p. 62 da mesma edição citada logo acima.

${ }^{460}$ Idem, estrofe 72, p. 400 .

461 Idem, idem, estrofes 78 e 79. 
descanso, deposita-se a sua "armadura para honrá-la" acima da tumba modesta. Seu corpo recebe as honras de Tancredo, que

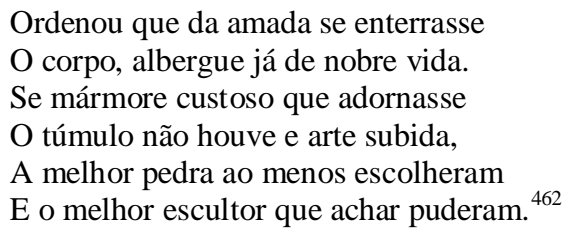

Observa-se na cena os cuidados de Tancredo para garantir as pompas possíveis, dignas da nobre combatente, e a preocupação em conservar a sua memória. A notícia da morte da guerreira Clorinda provoca comoção na cidade. A sua perda é sentida coletivamente, de uma maneira simetricamente oposta ao destino da prostituta obscura, sepultada sem glória em $O$ poema do frade. Se de um lado manifesta-se a guerreira épica e divinizada, modelo da "dama de corte, soberba, impenetrável enigmática", elevada a ideal de espiritualidade para o crente Tancredo $^{463}$, no segundo caso a beleza de Consuelo no poema alvaresiano entra em conflito com sua condição de objeto mercantil, visto que ela encarna a ideia de arte venalizada. ${ }^{464}$ Clorinda ainda está inserida em um mundo épico remanescente, regido pela unidade entre a fé e o belicismo que movia as multidões de cruzados e missionários.

Por fim, a presença de Consuelo enlouquecida pela perda do amado é comparada pelo narrador de $O$ poema do frade à tragédia da donzela grega Haideia, no Don Juan de Lord Byron. No terceiro canto do poema alvaresiano, lamenta-se o estado de completo abandono do cadáver de Jônatas nas areias frias, mais infeliz do que herói byroniano, salvo por "oriental donzela":

\section{LXXI}

Com o seio a bater em seda incerta Não veio Haideia, não, ao naufragado Ninguém passou: a praia era deserta, E o mar adormecia sossegado,

Só a maré que as ondas tremulava

A nênia à podridão lhe rouquejava! ${ }^{465}$

\footnotetext{
${ }^{462}$ Idem, estrofe 94, p.406.

463 Nota de LUCCHESI, Marco, in: TASSO, Torquato. Jerusalém Libertada, 1998, p.638.

${ }^{464}$ A guerreira de Jerusalém Libertada é a virgem inalcançável, impassível e destemida, distante do perfil de amante sedutora encontrado nas personagens Armida e Hermínia, vilãs no poema de Tasso. A condição de prostituta aproxima Consuelo, em alguns aspectos, destas últimas.

465 AZEVEDO, Álvares de. "O poema do frade", 2002, Canto Terceiro, p. 339.
} 
Haideia encarna o ideal romântico de poesia ingênua, ainda integrada à natureza exuberante e ensolarada do mar Mediterrâneo. A donzela grega salva o naufragado libertino Don Juan, proporcionando-lhe uma época de idílio. No entanto, o romance dos dois é proibido pelo pai da moça, e Haideia perece traumatizada diante da violência sofrida por seu amado. ${ }^{466}$ Jônatas, diferente de Don Juan, não tem a chance de ser despertado para a vida e para a vivência do amor pleno, ainda que transitório. À maneira de Haideia, Consuelo também surge para resgatar o amado afogado, porém sem chances de revivê-lo. A sensação de fracasso e impossibilidade em $O$ poema do frade é realçada em seu contraste com o poema byroniano.

Diferente da grega Haideia, a moderna prostituta de Álvares de Azevedo está consciente de que não pode amar. Seus sentimentos, limitados pelas trocas mercantis, fazem com que Jônatas os interprete como indiferença, e não como impossibilidade. $\mathrm{O}$ amante contrariado a vê como uma estátua cruel, repleta de lodo, cujo "morto coração era de areia". ${ }^{467}$ Criatura do mundo profano, ela "riu-se dos amores" e do amado enfebrecido "perdendo a vida" romanticamente por amor. Consuelo, tal como o coveiro descrido do Canto Quinto, encarna em parte uma consciência irônica, ciente da impossibilidade do amor ideal no mundo regido pelo automatismo e pelo senso de lucro burguês. O libertino Jônatas, por outro lado, mantém-se ingênuo ao amar, sucumbindo antes dela às contradições do mundo: a "insônia do martírio" o leva a "afogar as ilusões da vida/ Na taça de mistério do suicida!".

Essa obsessão de Jônatas pelo o amor ideal e puro gera um pensamento fixo ("Era só ela o seu pensar"), a ponto do narrador pontuar que "Tinha na harpa do gênio uma só corda". ${ }^{468}$ Nos capítulos anteriores desta dissertação, comentou-se a respeito da crítica de Álvares de Azevedo a um romantismo da moda excessivamente lírico, que ele chama de "lamartiniano". Esta poesia, Azevedo afirma, é pautada pela monotonia e pelos clichês, incompatível com o ideal de variação miscelânica encontrado no estilo do narrador de $O$ poema do frade. ${ }^{469}$ Tendo isso em vista, não é de se estranhar a impassibilidade do coração de Consuelo, comparado a uma lira emudecida diante do

\footnotetext{
466 É interessante notar que O Canto Segundo, que apresenta Consuelo, se abre como uma epígrafe do poema Don Juan, que faz referência à loucura de Haideia, metaforizada na imagem do lírio pendente sob o peso da chuva: "And her head droop'd, as when the lily lies/ O' ercharged with rain".

${ }^{467}$ AZEVEDO, Álvares de. "O poema do frade”, 2002, Canto Terceiro, estrofe XLII, p. 333.

468 Idem, idem, estrofe XXXVIII, p. 332.

469 Cf. a discussão sobre o topos do Fiat Lux e o princípio miscelânico no segundo capítulo desta dissertação.
} 
desespero amoroso do monocórdio Jônatas — este, ingenuamente crédulo e incapaz de autocrítica naquela altura:

XL

E o anjo? não o amou? quando ele em fogo

Ardente a fronte pálida pendia,

E como um ai de solitário afogo

O peito sufocado lhe gemia,

Não bateu-lhe jamais qual numa lira

Esse vento de amor que nos delira?

Neste sentido, o sorriso zombeteriro, "rir d'escárnio e dó”, “Anátema!” ao amor puro que Jônatas enxerga, na face de Consuelo revela-se a ironia romântica, empenhada em corrigir os excessos de uma lírica unilateralmente idealizada. Embora dotada dessa capacidade de humor negro e crueldade, Consuelo também acaba por perecer depois de Jônatas. $^{470}$

Há uma gradação descendente ao se comparar Clorinda, Ofélia, Haideia e Consuelo, levando-se em conta uma origem mais, ou menos, nobre dessas figuras femininas e os seus desfechos trágicos. Deve-se ter em mente que na teoria tradicional dos gêneros clássicos, a tragédia é um gênero nobre, elevado, destinado a cantar os feitos aristocráticos. $\mathrm{O}$ enterro indigente de uma prostituta fadada ao esquecimento e ao anonimato gera uma dissonância na grandeza do gênero. O mesmo sentido de rebaixamento é notado no curioso movimento de ascensão e queda, que parte do etéreo charuto, detentor da fumaça transcendente, em seu mergulho fatal nas águas marítimas, até desembocar na imagem grotesca de um cadáver rejeitado pelas ondas, exposto sobre as areias de uma praia solitária. O rebaixamento de Jônatas à pura materialidade nega a sua individualidade e o nivela a todos os seres viventes, fadados à mesma podridão. Essa tendência ao nivelamento para baixo revela a negatividade e a melancolia que perpassam todo $O$ poema do frade, e que se intensificam em seus últimos três cantos.

\section{A solidão do narrador moderno}

A solidão de Jônatas e Consuelo durante o seu momento de morte sugere a impossibilidade da conservação de uma memória gloriosa, segundo os moldes épicos, ${ }^{470}$ O sofrimento de Consuelo, mostrado na abertura do Canto Segundo, revela a sua consciência quanto a
impossibilidade do amor num mundo degradado e sem esperanças. 
capaz de eternizá-los e livrá-los do esquecimento coletivo. Essa questão pode ser pensada segundo a teoria do narrador de Walter Benjamin. A solidão e a subjetivação do discurso do frade na obra de Álvares de Azevedo também ligam-se à impossibilidade da narrativa oral e comunitária na modernidade. A relativização dos valores e a fragmentação da realidade geram a dificuldade de comunicação com um mundo surdo ao poético e ao maravilhoso, levando a literatura a se voltar, muitas vezes, para o diálogo possível com um auditório interno. São essas as questões discutidas no restante do presente capítulo, com base na análise do discurso do narrador de $O$ poema do frade, sobretudo na metade final do Canto Quinto (na altura das vinte últimas estrofes); ali, Jônatas e Consuelo já se encontram mortos, mas o discurso segue, estendido com base apenas na pura meditação do narrador. Logo após a morte de Consuelo, ele anuncia que encerrará o poema:

XXVI

E agora - boa noite! eu me despeço

Desta vez para sempre do poema:

Como soberbo sou, perdões não peço.

Mas como sou chorão, deixai que gema,

Que dê largas a est'alma entumecida

Na dor de tão solene despedida! ${ }^{471}$

Embora ele se despeça "Desta vez para sempre do poema", prolonga-o até a estrofe de número L. Sem precisar se preocupar com as personagens, o frade se dedica a dar "largas" a seus afetos e digressões: "como sou chorão, deixai que gema", afirma. O emprego do adjetivo na forma superlativa para se autoqualificar sugere a sua tendência ao exagero passional no discurso. Daí em diante, sua narrativa torna-se cada vez mais reflexiva, voltando os seus esforços em busca de uma expressão capaz de dar conta do tema da despedida, ao mesmo tempo ligado tanto à morte como significado do fim da existência, quanto ao encerramento do poema, já sugerido na metade do Canto Quinto. Paradoxalmente, a reflexão sobre o "fim" adia a finalização de $O$ poema do frade.

A solidão de seu narrador, assim como a fragilidade de suas personagens, que morrem incapazes de realizar feitos heroicos ou amorosos de maneira plena, estão vinculados à crise da arte de contar histórias no mundo contemporâneo, tal como apontada por Walter Benjamin. O estudioso afirma que a "arte de narrar é uma prática em processo de extinção"; o homem moderno, cada vez mais traumatizado e mudo não

471 O tema do "boa noite" é uma tópica de remate clássica, conforme CURTIUS, Ernst Robert. Literatura Europeia e Idade Média Latina. São Paulo: Hucitec/Edusp, 1996, pp. 135-136. 
consegue comunicar as suas experiências pobres e restritas. ${ }^{472}$ A rapidez e a descontinuidade dos acontecimentos não permitem o tempo necessário para a assimilação e elaboração de experiências extremas como a guerra, por exemplo.

A nova forma de comunicação vigente, Benjamin ressalta, é a informação. A burguesia e o capitalismo têm como seu porta-voz a imprensa, ancorada na técnica industrial e em um forte senso de abreviação temporal. Nas mensagens que produz, valoriza-se a especificidade e a instantaneidade de conteúdos datados, descartados tão logo são consumidos. A informação necessita vir sempre acompanhada de explicações que permitam situá-la em um "agora" verificável. Benjamin a contrapõe à narração tradicional. A primeira está fortemente atrelada ao registro escrito, ao isolamento, e não se vincula diretamente à necessidade de uma comunidade de ouvintes. A segunda, Benjamin destaca, tem as suas raízes no conhecimento compartilhado por meio de registros orais, conservados pela coletividade ao longo das gerações.

As antigas narrativas resultavam do lento processo de sedimentação extraído da sabedoria anônima, na combinação de saberes das tradições locais acrescidos das experiências trazidas pelos viajantes, oriundos de terras longínquas. Os "narradores natos" são hábeis em comunicar esse legado constituído pela lenta observação popular. Por isso, o narrador é alguém que "sabe dar conselhos", e têm forte senso utilitário. Frequentemente seus relatos guardam "um ensinamento moral, uma sugestão prática, um provérbio, uma norma de vida" 473 , aspecto que faz dos narradores antigos mestres e sábios. Sua matéria prima essencial é a experiência. Nesse sentido, pode-se conceber que "os provérbios são ruínas de antigas narrativas".

Diferente da informação, que reforça a sua autoridade com base na verificação do aqui e agora, a autoridade da narrativa oral é inverificável, por abarcar distâncias longínquas, tanto espaciais quanto temporais. Ela não exclui o miraculoso, o misterioso, e nem possui a pretensão de explicar tudo e esgotar a mensagem apresentada, como ocorre no caso da informação. A narrativa oral insere o seu ouvinte em um mundo de espanto e reflexão sem fim; continua a produzir ressonâncias ao longo dos tempos, saindo fortalecida desse processo. É repassada, memorizada, repetida, recontada e enriquecida pela experiência de cada sujeito que a conserva e compartilha, e desse modo contribui para o caráter inesgotável dessa forma de comunicação.

${ }^{472}$ BENJAMIN, Walter. "O narrador: Considerações sobre a obra de Nikolai Leskov", in: Magia e técnica, arte e política: ensaios sobre literatura e história da cultura. 7. ed. São Paulo: Brasiliense, 1994 - Obras Escolhidas, vol I, p.198.

${ }^{473}$ Idem, idem, p.200. 
A narrativa oral tem vocação para a exterioridade, quer tocar o concreto. A "sóbria concisão" de sua forma se funda na conservação de atitudes e acontecimentos essenciais, e descarta as sutilezas psicológicas. As narrativas orais são inseridas na rotina e no ritmo do trabalho manual de fiadeiras e tecelãs. Walter Benjamin destaca a analogia do entrecruzamento dos fios do tecido com a estrutura da trama narrativa antiga. Ela cresce camada por camada, com paciência, como se fosse um produto artesanal, comprometida com a eternidade, livre da pressa que acomete o homem moderno em sua linha de produção. ${ }^{474}$ Benjamin aponta a ligação entre as tarefas manuais e a voz: a matéria do narrador é a vida humana. O trabalho contemporâneo, por sua vez, aliena o sujeito em um ritmo mecânico e esvaziado de sentido. A partir dele, não é possível comunicar a experiência, desvinculada da memória coletiva e do "lado épico da verdade". ${ }^{475}$

Segundo Walter Benjamin, a experiência da morte era entendida no mundo antigo segundo a concepção de eternidade. Morrer significava completar-se, fechar o ciclo de uma existência que alcança o seu auge, levando consigo uma carga de experiência e uma lição final a comunicar. No mundo moderno, a morte foi expulsa do espaço comunitário, ao ser exilada na esfera privada e nas paredes de hospitais e sanatórios, responsáveis por ocultá-la da vista alheia: "Hoje a morte é cada vez mais expulsa do universo dos vivos"; doravante, seu mistério era parte estruturante do cotidiano, e não havia casa sem uma cama na qual não se tivesse velado um "último suspiro". 476

A autoridade da narrativa oral coincide com a da morte, que "é a sanção de tudo o que o narrador pode contar. É da morte que ele deriva sua autoridade. Em outras palavras: suas histórias remetem à história natural", pois são o fecho de um ciclo de vida. ${ }^{477} \mathrm{O}$ narrador antigo concebe a história em bases escatológicas, englobando tanto a origem divina do mundo quanto a salvação da alma do sujeito no "fim da história". O homem contemporâneo, por sua vez, não está mais harmonicamente inserido em uma unidade com o mundo. A natureza se torna indiferente ao destino humano: os novos planetas descobertos já não fazem parte do horóscopo. Walter Benjamin afirma, com

\footnotetext{
${ }^{474}$ Segundo Benjamin, o tédio e monotonia em extinção são vistos como valores negativos na vida moderna, pois o moderno se pauta pelo deslocamento rápido de tudo que é interessante.

${ }^{475}$ Idem, idem, pp.200-201. A narrativa épica deita suas raízes num tempo eterno, guardada nas memórias das gerações. Benjamin define a memória como a "mais épica de todas as faculdades", p. 210.

476 Idem, idem, p. 207.

477 Idem, idem, p. 208.
} 
esse exemplo, a impossibilidade de uma literatura ingênua no mundo moderno, que funde sujeito e cosmos, conforme os termos de Schiller.

O romance surge como a expressão de uma literatura sentimental, segundo a qual o mundo é cindido em "realidade", de um lado, e "ideal", de outro. O gênero em questão anuncia a "a morte da narrativa" de raízes orais, atrelando-a aos limites do livro, produto escrito, distanciado das tradições orais que geravam a epopeia. $\mathrm{O}$ romance pressupõe o silêncio e o isolamento. ${ }^{478}$ Ele já nasce em crise, como expressão da perplexidade e do isolamento do sujeito diante das contradições produzidas pelo progresso econômico. ${ }^{479}$

Em O poema do frade, a incorporação da constante reflexão meditativa à narrativa pressupõe essa consciência do processo de escrita sobre a superfície do livro. As referências do narrador à forma que emprega em seu poema sugerem a busca pela tentativa de comunicação, em um contexto no qual a experiência coletiva se mostra limitada pelo isolamento cada vez maior do indivíduo na esfera privada.

Neste contexto, o heroísmo de Jônatas não se realiza: o libertino não pode ser guerreiro e tampouco alcançar a glória e o reconhecimento do público, como poeta. Nos escassos trechos em que o jovem libertino aparece, nos cantos primeiro, segundo e terceiro, ele pouco age; não há uma fala sequer de sua boca que não seja mediada pelo frade, narrador do poema. Seus traços físicos, isentos de detalhamento, fazem com que a personagem seja facilmente alegorizada, encarnando princípios universalizantes de sua época, mas também faz com que ela se assemelhe a uma espécie de esboço ou fantasma, de contornos indefinidos e vaga presença. Sua morte é anunciada no Canto Terceiro; entretanto o poema segue sem seu herói por mais dois cantos. As circunstâncias de sua morte também são apresentadas ao leitor de maneira indireta. Se por um lado a personagem pouco age, é na maioria das vezes retratada entregue a vastas meditações e contemplações, tal como o frade-narrador. Há nela uma evidente desproporção entre a pouca atividade exercida no plano físico e o excesso de movimento em sua mente.

Paolo D'Angelo aponta na personagem Hamlet, de Shakespeare, o paradigma do herói sentimental romântico. No atormentado príncipe da Dinamarca observa-se a

\footnotetext{
${ }^{478}$ De acordo com Leyla Perrone-Moisés, a linguagem não presentifica ou fixa a coisa, sendo antes fantasma, ausência e representação da coisa, e não coisa em si. Nas palavras da estudiosa, a poesia moderna é consciente do "discurso abstratizante": "A linguagem foi deixando de ser experimentada como instrumento, mediação, representação da presença, para ser encarada como falta-de-ser”, in: PERRONEMOISÉS, Leyla. "O Vácuo-Pessoa”. In: Fernando Pessoa: aquém do eu, além do outro. São Paulo, Martins Fontes, 2001, p.93.

${ }^{479}$ Para Walter Benjamin, Dom Quixote é exemplo de um mundo em crise, sem lugar para a sabedoria e para as tradições, rebaixadas ao ridículo. Cf. BENJAMIN, Walter. “O narrador”, 1994, p. 201.
} 
“desmesurada desproporção entre as energias activas e a energia do pensamento". ${ }^{480}$ A personagem, tomada pelo conflito moral e pela dúvida, é caracterizada pelo perfil hesitante, reflexivo, voltado para a abstração e a filosofia. De acordo com Paolo D’Angelo, Hamlet se afasta do modelo do herói ingênuo, uma vez que este último está em harmonia consigo mesmo e volta as suas energias para a atuação no mundo exterior. Por meio da unidade entre suas crenças e seu corpo vigoroso, o herói ingênuo se relaciona de maneira direta com a realidade. ${ }^{481} \mathrm{O}$ sentimental, por sua vez, a nega a isso, e aspira pelo ideal: ele está divido entre essas duas dimensões. ${ }^{482}$ Tal como Hamlet, ele relativiza a sua compreensão do mundo, em uma época na qual os valores não são mais absolutos; ele pensa criticamente sobre o seu pensar e sobre o seu agir no mundo, tornando as suas atitudes menos espontâneas e naturais.

Diante da vitalidade do herói épico, salta aos olhos a marcante debilidade física e a hesitação moral de Jônatas em $O$ poema do frade, consumido pelo vício, pela descrença e pelo desejo de suicídio. ${ }^{483} \mathrm{O}$ herói sentimental do poema de Azevedo sucumbe ao mundo à sua volta, e se reduz precocemente à figura de um cadáver, expressão do disforme e do grotesco. Não é fortuito o movimento digressivo na metade do Canto Terceiro, que parte do charuto - objeto humanizado pelo afeto do frade, e portador da fumaça etérea e idílica —, para então desembocar na imagem do corpo vazio do libertino, rebaixado ao inumano. O herói de $O$ poema do frade, incapaz de

${ }^{480}$ D’ANGELO, Paolo. A estética do romantismo. Tradução Isabel Teresa Santos. Lisboa: Estampa, 1998, p. 43.

481 A melancolia e a imobilidade física do herói reflexivo destoam do "caráter ativo e belicoso" do guerreiro épico. Vagner Camilo destaca a escolha do nome do herói de Iracema, de José de Alencar, como um ponto de partida interessante para se pensar esta questão. $\mathrm{O}$ colonizador Martim tem seu nome derivado de Marte, o deus romano da guerra. Cf. CAMILO, Vagner. "Mito e história em Iracema", in: Novos estudos, CEBRAP, 78, jul. 2007,pp.180-181. A prudência e a bravura são esperadas nele, pois "é inegável que a fraqueza de caráter, a indecisão, não é própria de um herói. Sobretudo de um herói de poema, cuja vontade deve dominar toda a ação dramática ou histórica". Cf. ALENCAR, José de. "Cartas sobre a Confederação dos Tamoios", in: Caminhos do pensamento crítico. Organização de Afrânio Coutinho. Rio de Janeiro: Pallas/ Instituto Nacional do Livro/ Ministério da Educação e da Cultura, 1980, vol. I, p.102. A iniciativa colérica, a atitude das personagens, tornam possível a epopeia. Segundo Curtius, nelas a ação tem fundamento em um herói colérico, como Aquiles, Rolando ou Cid, ou em um deus rancoroso, tais como Posseidon, na Odisseia, ou Juno, na Eneida. Cf. CURTIUS. Literatura Europeia e Idade Média Latina. São Paulo: Hucitec/Edusp, 1996, p.226.

482 Nas palavras de Paolo D'Angelo, “enquanto o poeta ingênuo constitui uma unidade com seu objeto, o poeta sentimental reflecte sobre este interpondo assim entre si e o objeto uma distância que acaba por se tornar intransponível", cf. D’ANGELO, 1998, p. 43.

483 Jaime Ginzburg lembra que a melancolia era considerada uma doença pouco "masculina" e viril na perspectiva da moralidade burguesa, "que a considerava algo perturbador para o padrão dominante de organização dos papéis sexuais na sociedade. GINZBURG, Jaime. "O conceito de fragmentação em suas elaborações no Romantismo e em textos da teoria da literatura contemporânea" In: IV Congresso da Associação Brasileira de Literatura Comparada, 1995, São Paulo. Literatura e Diferença. IV Congresso ABRALIC. São Paulo: ABRALIC, 1995, p.67. Hamlet afirma que "Nos corpos frágeis a imaginação trabalha com mais força", in: SHAKESPEARE, William. Hamlet; 2010, p.91. 
realizar-se e agir no mundo, é um sujeito precário, exibindo a "fragilidade de um rosto que, mal esboçado, dissipa-se como fumaça". ${ }^{484}$ Ele e Consuelo morrem em uma situação diferente, por exemplo, de Clorinda, Ofélia ou mesmo de Hamlet, guerreiros e aristocratas. O príncipe da Dinamarca perece, mas conta com o relato do amigo Horácio, dedicado a comunicar a sua experiência à coletividade e conservar a memória do príncipe. ${ }^{485}$

O frade alvaresiano é dotado do mesmo espírito hamletiano que caracteriza muitos dos heróis modernos e problemáticos. Ele insiste na célebre sentença do "ser ou não ser" ${ }^{486}$, e se questiona se realmente seria possível a imortalidade da alma após a morte: "E quem sabe? é a dúvida do Hamleto/ E o - ser e o não ser — que toma o passo/ (...)/ Mas o que é o morrer? e a sepultura/ Que mistérios contém na noite escura?" ${ }^{487}$ Em uma realidade na qual a certeza do Paraíso como recompensa para a alma cansada já não é consenso, o frade-narrador indaga se a morte aterrorizadora é apenas um sono inacabável: "E quem sabe? é dormir... e tão somente?/ — E o sono que

\footnotetext{
${ }^{484}$ A expressão é de Alcides Villaça, in: "Na intimidade romântica". In: AZEVEDO, Álvares de. Lira dos vinte anos. São Paulo: FTD, 1994, p. 15.

O afogamento de Jônatas, bem como o seu perfil descrente, são similares aos que Álvares de Azevedo emprega para descrever a morte do poeta Percy Shelley ("o cético apertando com os braços no peito vazio a coroa seca das esperanças descridas"), no ensaio Alfred de Musset: Jacques Rolla. Nele, o suicídio de Shelley é apresentado como uma tendência universal do espírito de seu tempo: "o coração de Shelley se enrijara daquele engelhar precoz que rói como um verme, e desvive nas veias a seiva de morte do Hamlet e a vitalidade do veneno de Byron. Shelley que revelara nas notas descridas do seu brilhante poema - a rainha $M a b$, o ateísmo mais frio, não podia reviver à crença - : e quando a sua febre esfriou, como ele o pedira num dos seus cantos, no ar quente da Itália, o seu último murmúrio perdeu-se no arfar monótono do mar, depois que Byron e Trelawney, nas praias do Mediterrâneo azul, ao sol puro, ao perfume das flores e dos laranjais, sepultaram-no em leito de areia, a mão do peregrino estranho pudera gravar-lhe sobre a lájea o epitáfio de Werner, o Alemão, que sofrera muito com [sic] a Madalena, e como ela merecia perdões". Cf. AZEVEDO, Álvares, 2000, pp. 703-704. As referências a Hamlet, a descrença religiosa, o envelhecimento precoce e a superfície de areia sobre a qual jaz o cadáver diante do mar (não por acaso uma imagem da infinitude romântica por excelência) são constantes em $O$ poema do frade, assim como a figura de Madalena, a quem Consuelo é comparada. No Canto Terceiro do poema em questão, o afogamento é comparado a um batismo, responsável por iniciar o cadáver no reino da morte: "Ah! mistérios! não rias, ceticismo,/ Do agoureiro terror que a morte fria/ Do banho do cadáver no batismo/ Os regelados nervos arrepia!/ Sono de chumbo, tálamo de terra,/ Que nodoa negra teu sudário encerra?", Cf. estrofe LIX, p. 336.

${ }^{485}$ Horácio, o amigo de Hamlet, sobrevive para contar a história, assegura uma continuidade: "O meu relato trará a verdade inteira", cf. SHAKESPEARE, William. Hamlet; 2010, p. 140. Nesse sentido, Horácio se tornará um narrador nos moldes antigos. Já no Canto Terceiro de $O$ poema do frade, o narrador sugere que o suicídio de Jônatas despreza as diferentes gerações de sua família, impedida de realizar o luto e guardar a sua memória coletivamente: "E o pai, não sonhas nele? ... e as cãs tão puras/ Daquela que embalou teu berço infausto,/ E na mágoa das suas desventuras/ Nem te pôde beijar o corpo exausto?/ Misérrima anciã! que só vivia/ Por ti - e por ti desce à noite fria!// E o filho? essa criança que palpita/ Nos seios que um insano amor consome,/ Que profanado amor gerou maldita,/ Que virá amanhã pedir seu nome!/ E que não saberá que sepultura/ Guarda o pai e o segredo em terra impura!", cf. AZEVEDO, Álvares de. "O poema do frade",, 2002, estrofes LXI e LXII, p. 337.

${ }^{486}$ Idem, idem, estrofe. LVIII, p. 336.

487 AZEVEDO, Álvares de. "O poema do frade", 2002, p. 336.
} 
as pálpebras lhe chumba?", ${ }^{488}$ Expressões caras ao vocabulário hamletiano como o não ser, o nada, o crânio e o verme continuam a ser explorados no Canto Quarto, dentro da mesma postura de incertezas antes assumida:

\section{XXXIV}

Se o nada não engole a criatura, Se inda sente o não ser da sepultura, Se além arqueja o desespero errante, Se há uma eternidade delirante, E dói sentir morder na carne impura O verme da saudade devorante!

\section{XXXV}

Tarde! quando eu morrer, e desprezado Ao corvo deem meu corpo desbotado, Derrama sobre mim teus mornos estos! Talvez reviva o fogo do passado Nas fibras rotas, nos infaustos restos Do cadáver no campo abandonado!

O emprego obsessivo da conjunção condicional "se" e do advérbio de dúvida “Talvez", no quarto verso da última sextilha acima, reforça o caráter especulativo do frade diante dos mistérios da morte. Como se aludiu mais acima, o mundo posterior às ruínas da Revolução Francesa não pode contar mais com a certeza recompensada de um paraíso celeste, que dê sentido à existência terrena. Em A Confissão de um Filho do Século, o narrador criado por Alfred de Musset lamenta a perda daquilo "que os consolava" e dava esperança em tempos de outrora. ${ }^{489}$ Segundo ele, pouco importava se as promessas do cristianismo eram mentira, pois o presente foi capaz de tirar tudo do ser humano, até mesmo as suas ilusões. A busca pela liberdade e o rompimento com o divino levaram, segundo ele, a uma condição de miséria existencial ainda mais

${ }^{488}$ Idem, cf. estr. LXXVI, p. 340. O príncipe Hamlet, por sua vez declara na obra de Shakespeare:

“(...) Quem aguentaria fardos,

Gemendo e suando numa vida servil,

Senão porque o terror de alguma coisa após a morte -

O país não descoberto, de cujos confins

Jamais voltou nenhum viajante - nos confunde a vontade,

Nos faz preferir e suportar os males que já temos,

A fugirmos pra outros que desconhecemos?

E assim a reflexão faz todos nós covardes.

E assim o matiz natural da decisão

Se transforma no doentio pálido do pensamento.

E empreitadas de vigor e coragem,

Refletidas demais, saem de seu caminho,

Perdem o nome de ação."

Cf. SHAKESPEARE, William. Hamlet, 2010, pp. 67-68.

${ }^{489}$ MUSSET, Alfred de. A Confissão de um Filho do Século. São Paulo: Editora Escala, sem data p. 18. 
aterradora do que a anterior, vivida no Antigo Regime, uma vez que agora o sujeito se depara com o puro vazio e o niilismo de sua vida terrena: "Quando, outrora, o opressor dizia: 'Para mim a terra!' - 'Para mim o céu', respondia o oprimido. E agora, que responderá?". ${ }^{490}$ Uma das consequências dessa ruptura com o destino traçado por uma providência divina é o questionamento do tabu do suicídio em $O$ poema do frade. Tal como Hamlet, o narrador alvaresiano não está convencido se o apressamento da morte proporcionaria punição por um pecado, ou simplesmente o repouso para uma consciência atormentada. O suicídio de Jônatas é o rompimento com o ideal de celebração da vida ou ainda a relativização da morte honrosa do herói épico antigo.

\section{Subjetivação das formas: o auditório interno}

Conforme O poema do frade caminha para o seu final, no Canto Quinto, a voz do frade-narrador ecoa solitária. Sem preocupar-se mais com as personagens Jônatas e Consuelo, ambas mortas, ele se entrega a devaneios e meditações que retardam o encerramento do poema durante pouco mais de duas dezenas de estrofes. O episódio da perda do charuto, que se apaga no Canto Terceiro, inicia uma nova etapa no texto, marcada pela tematização obsessiva das ideias de morte e luto. $\mathrm{O}$ frade-narrador, identificado com a poesia libertina de Jônatas, desejando a beleza degradada de Consuelo, insere-se no mesmo horizonte sombrio e solitário, e projeta também a sua destruição próxima. Desde o Canto Terceiro, ao preludiar a morte de Jônatas, o narrador dedica-se a tecer considerações permeadas de imagens ligadas à ideia de esgotamento, esterilidade, sede e cansaço, unificadas pelas indagações acerca do tema maior dos mistérios que cercam a morte e o ser:

\section{$\mathrm{L}$}

E cedo morrerei: sinto-o, nas veias

O meu sangue se escoa vagaroso

Como um rio que seca nas areias,

Como donzela, que desmaia em gozo!

Teus lábios, fada minha, me queimaram,

E as lânguidas artérias me esgotaram!

(...)

\section{LVII}

\footnotetext{
${ }^{490}$ Idem, idem, idem.
} 
E assim eu morrerei: co'a sede ainda

Amargosa no lábio ressecado

Cansando os olhos na extensão infinda,

Perguntando se a crença do passado

Também verei no lodo revolvida....

E como tu sufocarei a vida!...

(...)

LXV

Dorme pois, desgraçado! no futuro

Além — no meu viver — quando a rminh'alma

Cândida se despir do manto impuro:

E quando a noite que o sofrer acalma

Nas pálpebras pesar-me o sono amigo

Do — nada — ao leito irei dormir contigo ${ }^{491}$

Nesta altura do Canto Terceiro, ainda se observa a referência a um "tu". No entanto, conforme o poema avança para o seu final e passa a centrar-se somente no frade, instaura-se um longo monólogo, movimentado apenas pelas meditações e devaneios do narrador, sobretudo após as primeiras quinze estrofes do Canto Quinto, nas quais se narra o sepultamento de Consuelo. Como se comentou acima, no presente capítulo desta dissertação, na estrofe XXVI ele anuncia o encerramento do poema; todavia, logo em seguida, afirma que deseja lamentar um pouco mais a "dor de tão solene despedida!". É interessante observar que embora entregue-se a um discurso prolixo mais uma vez, o narrador traz duas imagens de sufocamento na mesma sextilha, ligadas à uma outra de anjo emudecido:

XXVII

Que prantos! que suspiros sufocados! Se eu gostasse dos versos eloquentes, Como eu descreveria bem rimados Do meu peito os anélitos frementes! Porém nos seios eu sufoco tudo, Porque da mágoa o serafim é mudo. ${ }^{492}$

Esta imagem de mudez é reforçada nas estrofes seguintes pelas ideias de silêncio e de impossibilidade: "Silêncio, coração, que a dor inflama!"493; "E o pobre sonhador a

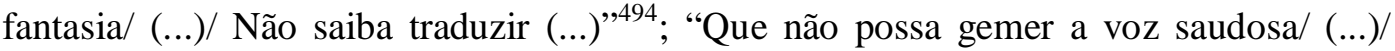
Para exprimir os pensamentos meus / Nos cantos melancólicos do adeus!"495, por

${ }^{491}$ AZEVEDO, Álvares de. "O poema do frade", 2002, Canto Terceiro, p. 338.

${ }^{492}$ Idem, idem, Canto Quinto, p. 356.

${ }^{493}$ Idem, idem, Canto Quinto, estrofe XXVIII, p. 356.

${ }^{494}$ Idem, idem, estrofe XXX, p. 357.

${ }^{495}$ Idem, idem, estrofe XXX, idem. 
exemplo. Vale ressaltar que, curiosamente, as imagens ligadas ao silêncio e à mudez estão vinculadas, por suas vez, ao seu contrário: abundam nas estrofes finais do Canto Quinto referências a "sons", "lira", "voz", "música”, só para citar os registros de metáforas ligadas ao campo semântico da linguagem musical presentes em apenas duas páginas (pp. 356-7). Tanto o silêncio como o som estão vinculados à mais sublime das linguagens para os românticos: a música. Este assunto será discutido com maior detalhamento ainda neste capítulo. No momento, apenas a ideia de silêncio será explorada, por incidir sobre o tema da solidão.

Mais adiante no Canto Quinto, o narrador refere-se mais uma vez ao silêncio, e o relaciona à ideia de solidão e à possibilidade de entregar-e livremente à reflexão:

\section{XLI}

Silêncio que eu amei, que eu procurava

Na varanda romântica e sombria,

Sorvendo dentro em mim o ar que sentia

Na fresca viração que se acordava!

Suspirando a cismar nessa atonia

Que de amor minhas pálpebras banhava!

\section{XLII}

Sobre as colunas o luar batendo

E nas palmeiras úmidas tremendo

Fitava-me o sossego, o mole engano

Em que se abisma o pensamento insano,

Que empalece da noite os sons bebendo

E harmonias escuta no Oceano!

\section{XLIII}

E vós, águas do mar, que me embalava

Ao som dos remos da gentil falua!

Onde a fronte de escuma se banhava,

E à morta luz da vagabunda lua

Cismava como a nuvem que flutua

Do escravo à nênia que soava! $!^{496}$

Conforme se vê nas estrofes acima, o silêncio favorece o sossego propício ao cismar do narrador, no qual "abisma o pensamento insano". Não é mais a voz de Jônatas ou Consuelo que ele diz ouvir: predominam os sons da natureza. Ao longe, sob a "morta luz" da lua, soa uma "nênia estranha" cantada por um escravo. Mais uma vez, uma imagem ligada ao tema da escravidão surge em $O$ poema do frade; no Canto Terceiro, a pátria era comparada a uma donzela violentamente prostituída e escravizada pelo estrangeiro, que a comprava com moedas. ${ }^{497} \mathrm{O}$ canto de morte ressoa no tempo presente

\footnotetext{
${ }^{496}$ Idem, idem, p.369.

${ }^{497}$ Idem, idem, Cf. estrofes LXIII e LXIV, p. 337.
} 
de decadência e corrupção moral. $\mathrm{O}$ eu poético refugia-se em sua interioridade nas estrofes finais do poema, todavia, a imagem do canto escravo, embora sutil, faz ressoar, ainda que ao longe, a barbárie do mundo venal, responsável por rebaixar o sujeito a objeto mercantil. Não é por acaso que o seu canto é uma nênia, identificada ao espírito fúnebre do frade-poeta, obcecado com os temas da morte, do nada, do vazio e da solidão.

Para Jean Starobinski há uma clara relação entre a "solidão radical" do narrador moderno e sua tendência a adotar um discurso devaneante, cada vez mais similar a um vasto monólogo. Segundo o estudioso, em Devaneios de um caminhante solitário, Jean-Jacques Rousseau escreve os seus devaneios para si próprio e, mais do que tomarse por destinatário "toma-se a si mesmo por tema de seu discurso". ${ }^{498}$ A escolha pela exploração do devaneio e do sonho, desdobrados na mente do sujeito, revela um processo contínuo de subjetivação de temas e formas; distanciado do mundo, o poeta refugia-se em si mesmo. Conforme Starobinski ressalta, há um evidente contraste entre a volúpia extraída do devaneio e a dor resultante do embate com o mundo circundante opressivo. $^{499}$

Todavia, Starobinski destaca uma contradição na tarefa proposta pelo poeta de fixar pela escrita o devaneio fugidio. A palavra quer fixá-lo, exteriorizá-lo, comunicá-lo a outrem; porém o devaneio, em seu estado puro, desdobra-se silencioso na interioridade do sujeito: é mudez e solidão. "O puro devaneio é interno e mudo, absorvido em uma fascinação fugidia. Exteriorizar-se, para a consciência sonhadora, é já sair do devaneio". ${ }^{500}$ Ao escrever, o autor encontra-se em estado de vigília, e tenta recriar por meio da palavra o efeito de um "equivalente aproximativo" do devaneio vivência sempre anterior ao ato de escrever. Esse distanciamento temporal gera lacunas e intervalos na memória do poeta que são posteriormente preenchidos pela sua imaginação. Portanto, o "devaneio segundo" dialoga com o primeiro; porém não possuirão jamais uma completa identidade. Como se observa, a palavra é um eco retardado do devaneio original; diante disso, a tarefa de escrever os devaneios apresenta-se como um paradoxo que revela a distância entre a palavra e a ideia que ela

498 STAROBINSKI, Jean. "Devaneio e transmutação". Rousseau: a transparência e o obstáculo. São Paulo: Companhia das Letras, 1991, p. 361.

${ }^{499}$ Idem, idem, p. 372.

${ }^{500}$ Idem, idem, p.362. "Escrever, ainda que para se dirigir apenas a si, é condenar-se à exterioridade, é remeter-de à leitura possível de um terceiro, e é, sobretudo, confiar-se a esses sinais de convenção que Rousseau (no Ensaio sobre a origem das línguas) considera como irremediavelmente estranhos à verdade viva do sentimento: quem quer que recorra à escrita cai no mundo infeliz dos objetos e dos meios opacos". Idem, idem. 
exprime: a palavra torna-se aqui o emblema da inadequação, ou da impossível identidade completa entre ela e a ideia ou o objeto que ela representa. ${ }^{501} \mathrm{O}$ estudo de Jean Starobinski é epigrafado com uma afirmação de Marcel Raymond, que salienta o fato de haver "poucos devaneios propriamente ditos em Rousseau", pois a ruptura com a longa tradição de discurso retórico não poderia ser feita facilmente, de uma hora para outra. $^{502} \mathrm{O}$ que há em Rousseau é a composição de um discurso que procura gerar o efeito de espontaneidade, ao mesmo tempo em que ressalta a consciência da árdua tarefa que isto representa.

A recriação do segundo devaneio — ou "devaneio duplicado", o "sonho de um sonho" - torna-o passível de redobramentos posteriores infinitos, ao se mesclar com a imaginação (re)criadora durante o processo de escrita. Não somente aí, mas ele também continuará a desdobrar-se "por ocasião das leituras posteriores", no interior das quais a ação da imaginação continua a interpretá-lo continuamente e a modificá-lo. ${ }^{503}$ Assim, há um redobramento pela escrita e outro pela leitura, que atuam nas lacunas da memória original e potencializam a capacidade reflexiva do devaneio de desdobrar-se infinitamente sobre si mesmo, prolongando a reflexão da reflexão, ou o sonho de um sonho, e assim por diante. O segundo devaneio está ligado ao devaneio primeiro, todavia é autônomo em relação a este, não existindo qualquer relação de hierarquia ou inferioridade entre ambos. ${ }^{504}$ Enquanto "o devaneio primeiro opera em plena crise, no instante presente", o segundo "opera a frio, no universo das 'segundas intenções"”: é uma recriação irônica, executada em completo estado de vigília. ${ }^{505}$

Starobinski ressalta que não deve-se confundir o devaneio real com o mero discurso livre. A escrita não coincide com o ato, mas antes é a representação deste ato, por meio do qual procura-se instaurar o efeito de unidade entre eles: "escrever não é apenas um ato de reflexão, uma rememoração a distância, mas uma revivescência.

\footnotetext{
501 Idem, idem, p.363.

502 RAYMOND, Marcel, apud STAROBINSKI, 1991, p.361.

503 "No curso do devaneio segundo, as flutuações do devaneio primeiro não são apenas transcritas: são interpretadas e modificadas". In: idem, idem, p. 364.

504 Idem, idem, p.366.

505 “A função do devaneio segundo consiste, então, em reabsorver a multiplicidade e a descontinuidade da experiência vivida, inventando um discurso unificador no seio do qual tudo viria compensar-se e igualarse. A unidade assim reconquistada pode então projetar-se retrospectivamente sobre a existência inteira, a ponto de, para a memória criadora, o passado reestruturar-se de maneira a assemelhar-se à obra empreendida, e dela receber o ritmo constante, a continuidade tranquila, marcada pela alternância regular dos passeios". In: idem, idem, p. 365. O devaneio segundo retoma o passado mas filtra-se pelo sentimento atual.
} 
Escrever é reviver. E se é verdade, de início, que escrever não é sonhar, todo o esforço de Rousseau visa suprimir a diferença entre a palavra e o que ela exprime". 506

A interminável reflexão sobre reflexão move o discurso meditativo do narrador no fecho de $O$ poema do frade. Suas especulações se multiplicam diante do mistério inviolável da morte. A incomensurabilidade de seu segredo resguarda a dignidade do sujeito, que passa a ser contaminado deste mesmo enigma, para além do entendimento humano e da vida prosaica. As duas estrofes finais, no canto de fechamento do poema, sugerem o desejo pela transcendência e pelo movimento infinito, conjugando as ideias de ida e retono, vida e morte:

\section{XLIX}

Terra do amor! ó minha mãe! Na vida Se o fado me levar em mágoa lenta Sempre nesta saudade esmorecida Que de tristes lembranças se alimenta! Na morte a minha fronte macilenta, Inda a ti volverei qual flor à vida!

\section{$\mathrm{L}$}

Viverei do que foi - dos sonhos meus! Da seiba do passado hei de essa flor Regar das quentes lágrimas do amor! E quando a luz apague-se nos céus E o frio coração à dor sucumba Inda murmurarei — adeus! — da tumba!

Observa-se um movimento inconcluso, embaralhando vida e morte de maneira deliberadamente confusa: "Na vida/ Se o fado me levar em mágoa lenta - (...) $\mathrm{Na}$ morte a minha fronte macilenta,/ Inda a ti volverei qual flor à vida!". O mesmo movimento aberto segue desenvolvido na estrofe seguinte: "E quando a luz apague-se nos céus/ E o frio coração à dor sucumba/ Inda murmurarei — adeus! — da tumba!" ${ }^{507}$. Tomado pela dúvida perante o mistério da morte, o narrador conjuga simultaneamente a expectativa de finitude e a de um prolongamento sem fim, que será continuado para além dele. A grande quantidade de travessões no trecho procura recriar o movimento do pensamento especulativo, que pondera a cada pequeno prosseguimento, com interpolações e considerações.

O caráter enigmático da morte torna-a um tema adequado ao estilo sublime durante o romantismo. Junto dela, manifesta-se a melancolia também como sentimento essencialmente sublime, misto de dor e prazer, medo e esperança de libertação dos

\footnotetext{
506 STAROBINSKI, idem, p. 363.

507 Os grifos são meus.
} 
limites do cotidiano estreito da vida burguesa. Walter Benjamin associa a melancolia à regência do planeta Saturno, senhor do tempo e das antíteses. O caráter reflexivo e irônico do melancólico o torna disposto a investigar os mistérios de maneira incansável, a ponto de roçar o demonismo identificado pelo desejo por um saber proibido, conforme o sentido bíblico encontrado no livro de Gênesis, do Velho Testamento. Por isso, a disposição aos "estudos demasiado profundos" e a busca sem fim pelo conhecimento se apresentam como manifestação demoníaca, ânsia por uma espiritualidade e saber absolutos, emancipados do Sagrado, tal como desejara Satã. De acordo com Walter Benjamin, "O modo de existência mais autêntico do Mal é o saber, e não a ação".

Na tradição cristã, a crença surge muitas vezes contraposta à dúvida e a indagação. Por isso, a vontade de conquista do saber absoluto demonstrada pelo sujeito humano é entendida como "miragem de uma espiritualidade absoluta, isto é, sem Deus, associada à matéria como sua contrapartida, e que só no Mal pode ser experimentada concretamente". Satã inspira a tentação pelo saber, desencadeador do delito: "Enquanto saber, a pulsão conduz ao abismo vazio do Mal, para que possa ali assegurar-se do infinito. Mas esse abismo é também o precipício sem fundo da meditação". 508 A sedução do infinito gera a "ilusão da liberdade" e estimula a "investigação do proibido", a ânsia de superar (ou transgredir) limites. O "abismo vazio do Mal” desperta a "ilusão da autonomia" no sujeito, que busca "segregar-se da comunidade dos crentes". A Virtude pressupõe um fim diante de si, o modelo único: Deus. Em contrapartida, "é próprio de toda depravação mover-se numa jornada infinita, no interior do abismo". 509

Em um mundo no qual não há mais garantia da existência de um paraíso celestial que aguarde o ser humano após a sua morte, o frade alvaresiano especula sobre a existência da alma e a possibilidade de sua imortalidade. Neste sentido, a figura do narrador religioso mescla-se com a do libertino transgressor e demoníaco e se afasta do missionário antigo, inabalável em sua crença. Vale lembrar que a epígrafe geral de $O$ poema do frade retoma uma afirmação do cético Don Juan de Molière, na qual a personagem-título defende o conhecimento assentado sobre a racionalidade do mundo material e verificável. Em crise metafísica, o frade alvaresiano, no entanto, alinha-se a um discurso relativizador, oscilando entre as diversas possibilidades. Ao estruturar as duas estrofes derradeiras do poema em imagens opostas (vida e morte), insiste em

\footnotetext{
${ }^{508}$ BENJAMIN, Walter. Origem do drama barroco alemão. Tradução de Sérgio Paulo Rouanet. São Paulo: Brasiliense, 1984, p.254.

509 Idem, idem, p. 253.
} 
ambas, no advérbio "inda", que reforça a ideia de continuidade e possibilidade de retorno futuro. Não há certeza alguma em sua fala, que é deixada em aberto; a constante expressão "inda" sugere o desejo do frade por uma transcendência: é o anseio romântico pelo infinito e pelo universal irremediavelmente perdidos.

A tendência do narrador em questão de "deixar-se levar e derivar ao sabor de sua reflexão" ${ }^{, 510}$ engendrada infinitamente por novos devaneios (estimulados por um tema sublime e enigmático como a morte - e a possibilidade ou não da imortalidade da alma -), está vinculada à concepção idealista de expressão no romantismo. Conforme Walter Benjamin explica, a unidade da obra de arte romântica aponta para um devir, evidenciado por sua estrutura aberta: sua representação deve pressupor a referência a uma obra de arte necessariamente maior que ela mesma. ${ }^{511}$ Benjanim explica que a obra de arte é, por um lado, "forma-de-exposição" e, por outro, "Ideia da Arte". ${ }^{512}$ A unidade da obra é relativa, e "permanece um ensaio no qual o um e o todo encontram-se reunidos" ${ }^{513} \mathrm{O}$ artista romântico é consciente da distância que separa a obra realizada daquela imaginada. Coloca-se o problema de representação de um ideal infinito e total numa forma concreta, finita, parcial. Cada obra de arte particular é um fragmento que aponta para um todo maior, apresentado como ideia a ser perseguida.

Para vencer a distância que separa a forma-de-exposição da Ideia da Arte, o artista romântico se vale da crítica, entendida como medium capaz de desdobrar-se de maneira infinita. Ela engendra uma cadeia reflexiva por meio da qual a obra de arte se volta sobre si mesma. Essa capacidade torna possível que esta última tome-se como o próprio objeto de sua crítica, infinitamente desdobrado pelo pensamento reflexivo: este é capaz de gerar um novo pensamento, e esse mais outro, formando uma interminável cadeia do "pensar do pensar e assim por diante". ${ }^{514}$ Essa capacidade de desdobramento infinito da crítica torna possível que "a limitação da obra singular" ligue-se "metodicamente à infinitude da arte". ${ }^{515}$ Processo inacabado, em trânsito, a obra de arte

\footnotetext{
${ }^{510}$ STAROBINSKI, Jean, 1991, p. 363.

511 BENJAMIN, Walter. O conceito de crítica de arte no romantismo alemão. São Paulo. Editora Iluminuras, 1999, p. 83.

${ }^{512}$ Idem, idem, p.92-93.

${ }^{513}$ Idem, idem, p.83.

${ }^{514}$ Idem, idem, p.39. Sobre a capacidade de desdobramento infinito do pensamento: "O pensar tem a particularidade de, próximo a si mesmo, pensar de preferência naquilo sobre o que ele pode pensar sem fim", in: SCHLEGEL, apud BENJAMIN, Walter, 1999, p.27.

515 BENJAMIN, Walter, 1999, p.76.
} 
se torna ensaio, projeto. Segundo Walter Benjamin assinala, o processo do "pensar do pensar" condiciona a forma da obra de arte moderna. 516

Cada uma delas possui um Ideal individual, imanente, cuja possibilidade de realização pressupõe não o julgamento da obra singular, mas a "exposição de suas relações com todas as demais obras e, finalmente, com a Ideia da arte". 517 O valor de uma obra de arte romântica não se assenta na ideia de perfeição, mas na sua possibilidade de desdobramento crítico (e criativo) ali imanente: "Apenas o incompleto pode ser compreendido, pode nos levar mais além. O completo pode ser apenas desfrutado". ${ }^{518}$ O processo de "desdobramento claro e ordenação no todo da arte" é a tarefa da crítica poética, que busca ampliar a obra em suas relações, fazendo-a dialogar com um conjunto maior. "Para tanto, esta nada mais deve fazer do que descobrir os planos ocultos da obra mesma, executar suas intenções veladas. No sentido da obra mesma, isto é, em sua reflexão, deve ir além e torná-la absoluta". 519

Para que a obra de arte singular seja dissolvida no medium da arte, o processo necessita de uma pluralidade de críticos que representam não necessariamente “intelectos empíricos, mas graus de reflexão personificados". ${ }^{520}$ Cada leitura é um novo recriar da obra de arte, entendida como potência a ser multiplicada ao infinito. O "desdobramento fecundo" ao qual ela pode ser submetida é chamado de crítica. Nesse sentido, a crítica se constitui em um momento essencial na realização da obra poética, encarada como um processo em andamento: "Essa crítica poética (...) exporá novamente a exposição, desejará formar ainda uma vez o já formado (...), irá completar a obra, rejuvenescê-la, configurá-la novamente. ${ }^{, 521}$ É possível afirmar que a obra de arte romântica foi de fato entendida pelo leitor quando ele é "capaz de agir dentro de seu espírito", "sem estreitar sua individualidade, traduzi-lo e alterá-lo multiplamente."522 Assim, a crítica romântica visa "muito menos o julgamento de uma obra do que o

516 Idem, idem, p.38. Segundo Benjamin, “A forma é, então, a expressão objetiva da reflexão própria à obra, que forma sua essência”, p. 80. A concepção idealista da obra de arte romântica pressupõe a duplicidade da mesma, que existe enquanto realização parcial, mas também como ideal imaginado, imanente: "Todo homem que é culto e se cultiva também contém um romance em seu interior. Não é, porém, necessário que o exteriorize e escreva.” In: SCHLEGEL, F. O dialeto dos fragmentos, 1997, p.32. 517 BENJAMIN, Walter, 1999, p.85.

518 Schlegel, apud BENJAMIN, 1999, p.78. Como aponta Friedrich Schlegel, "Do ponto de vista romântico, também as degenerações excêntricas e monstruosas da poesia têm seu valor como materiais e exercícios preparatórios da universalidade, desde que nelas haja alguma coisa, desde que sejam originais.”, in: SCHLEGEL, F. O dialeto dos fragmentos, 1997, p.69.

519 BENJAMIN, Walter, 1999, p.77.

520 Idem, idem, p.76.

521 SCHLEGEL, Apud BENJAMIN, 1999, p.77.

522 NOVALIS, Pólen: fragmentos, diálogos, monólogo. Trad., apresentação e notas de Rubens Rodrigues Torres Filho. São Paulo: Iluminuras, 1998, p.55. 
método de seu acabamento". ${ }^{523}$ Segundo Friedrich Schlegel, o escritor "Não quer produzir nenhum efeito determinado sobre ele [o leitor], mas com ele entra na sagrada relação da mais íntima sinfilosofia ou simpoesia". ${ }^{24}$

Conforme foi salientado acima, a obra de arte individual deve ser encarada em relação a toda a poética de um autor, ou mesmo em relação a todo o conjunto da literatura universal, retomado em constante diálogo, por meio de epígrafes ou citações, entre outros recursos: os romances de um único autor, por exemplo, são variações de um grande único romance: "Não raro todos os romances de um autor são manifestações interdependentes uns dos outros e, de certo modo, apenas um romance". ${ }^{525} \mathrm{O}$ conjunto de livros de toda a literatura compõe peças de um mosaico, que formariam um livro total, universal, construído incansavelmente em devir:

Todos os poemas clássicos dos antigos estão indissoluvelmente ligados, formam um todo orgânico, são, corretamente considerados, apenas um poema, o único no qual a própria poesia parece completa. De uma maneira semelhante, na literatura completa, todos os livros devem ser apenas um livro, e num tal livro em eterno devir se revelará o evangelho da humanidade e da formação. ${ }^{526}$

Promover a combinação e a conexão das obras de arte é a maneira de caminhar rumo à unidade e ao acabamento do conjunto, fazendo a passagem da forma-deexposição à Ideia das formas. A obra de arte é simultaneamente uma miniatura autônoma e parte de um grande todo: fragmento, ou "porco-espinho", como prefere Friedrich Schlegel: "Um fragmento tem de ser como uma pequena obra de arte, totalmente separado do mundo circundante e perfeito e acabado em si mesmo como um porco-espinho". 527 Como a teoria romântica pontua, o porco-espinho é hostil e isolado do mundo, mas ao mesmo tempo os seus espinhos apontam para todas as direções do mundo circundante.

Em $O$ gênio romântico, Márcio Suzuki explica que o percurso reflexivo percorrido no discurso romântico não é linear: "ele pode proceder por avanços e recuos,

\footnotetext{
${ }^{523}$ BENJAMIN, Walter, 1999, p.77. Benjamin afirma: "O conceito de medida encontra-se distante do romantismo, que não se preocupava com nenhum a priori do conteúdo, com nenhum elemento medidor da arte. Juntamente com o conceito de beleza, ele [o romantismo] rejeita não apenas as regras como também a medida, e sua poesia é não só sem regras como ainda sem medida", cf. p.122.

${ }^{524}$ SCHLEGEL, Friedrich. O dialeto dos fragmentos, 1997, p.38.

525 Idem, idem, p.34.

526 Idem, idem, p. 156.

527 Idem, idem, p. 82. Em $O$ poema do frade, observa-se o embate entre a forma em miniatura moderna e a concepção monumental da epopeia.
} 
andar em ziguezague", sem perder o todo de vista. ${ }^{528}$ A estrutura nessa poesia só pode ser concebida "sem nenhuma hierarquização, pela determinação recíproca, pela alternância" e pela combinação de seus campos em oposição. ${ }^{529}$ A tarefa da reflexão na crítica romântica, segundo explica Márcio Suzuki, é "descobrir e reconstruir a unidade da obra" ${ }^{530}$ Ao comparar o que se disse e o que se quis dizer, a crítica unifica pelo entendimento o espírito e a letra de uma obra. A meta assumida pelo gênio — a tensa aproximação entre os campos distintos separados por uma distância infinita —, implica a inevitável desproporção entre a exigência e o resultado de sua obra ${ }^{531}$ : o produto estético aponta para o indizível e para o incomensurável do texto total, obra em devir, com a qual dialoga. Walter Benjamin, por sua vez, lembra que, para Friedrich Schlegel, crítica e fragmento são, essencialmente, sinônimos: "qualquer fragmento é crítico", ou ainda, "crítico e fragmento seriam tautológicos". 532

O texto romântico requer a participação ativa do leitor, e para tanto prevê lacunas nas quais a imaginação deste último possa atuar livremente. Quando poesia e teoria se pressupõem, o artista e o crítico devem coincidir. Nesta perspectiva, é esperado que o artista seja o primeiro e maior crítico de sua própria obra, já no momento da criação. ${ }^{533}$ Antes do romantismo, Laurence Sterne afirmava em A vida e as opiniões do cavalheiro Tristram Shandy que: "O respeito mais verdadeiro que podeis mostrar pelo entendimento do leitor será dividir amigavelmente a tarefa com ele, deixando-o imaginar, por sua vez, tanto quanto imaginais vós mesmo."

O romantismo faz coincidir a produção e a fruição da obra. Refletir e contemplar se tornam, em certa medida, sinônimo de produzir. ${ }^{535}$ Nesta estética, todo homem é artista e possui gênio interior. $\mathrm{O}$ que se costuma conhecer como gênio é gênio do gênio. Por isso, o leitor romântico é convidado a ser uma força cooperante e ativa: "ter gênio significa antes de mais doar e suscitar no fruidor uma força análoga àquela que foi usada na criação". ${ }^{536}$ Nesse sentido, a crítica se torna a "capacidade de captar a lei

\footnotetext{
${ }^{528}$ SUZUKI, Márcio. O gênio romântico: crítica e história da filosofia em Friedrich Schlegel. São Paulo: Iluminuras, 1998, p.124.

${ }^{529}$ Idem, idem, p. 127.

${ }^{530}$ Idem, idem, p.39.

${ }^{531}$ Idem, idem, p. 180.

${ }^{532}$ SCHLEGEL, Friedrich, Apud BENJAMIN, Walter, 1999, p.59.

533 BENJAMIN, Walter. 1999, p. 72-79.

${ }^{534}$ STERNE, Laurence. A vida e as opiniões do cavalheiro Tristram Shandy. 1984, p. 136.

535 D'ANGELO, Paolo. A estética do romantismo, 1998, p. 100.

${ }^{536}$ Idem, idem, p.119. O grande trunfo do gênio romântico é a sua capacidade de autolimitação, segundo a qual estabelece leis a si mesmo. Ele independe de normas retóricas fixas e externas a ele, podendo também modificá-las livremente, segundo as suas necessidades internas. Conforme Paolo D’Angelo, o
} 
através da qual a obra foi construída, saber percorrer o caminho que ela já percorreu" ${ }^{\text {" }} 37$, ou ainda "A outra via que a crítica pode percorrer consiste em oferecer uma nova obra de arte que cresça sobre a primeira (...) só a arte ajuda a compreender a arte". ${ }^{538}$

Segundo a teoria de Longino, essa "força análoga àquela que foi usada na criação" é especialmente favorecida pelo estilo sublime. Deve-se lembrar que este estilo busca criar o efeito de simultaneidade entre campos em oposição: ideia e palavra, pensamento e ato, ou mesmo entre autor e leitor. ${ }^{539}$ Nele, o acontecimento da leitura deve se entrecruzar com o sopro interior que animou a composição da obra. A intensa emoção ou mesmo a perturbação experimentada pelo leitor evoca uma "superior solidariedade" entre este e o autor, tornando possível manter viva a tradição literária, que pode ultrapassar o obstáculo da distância temporal: "o sublime vence o silêncio dos séculos" ${ }^{540}$, e cria um laço universal adequado a este estilo grandioso.

No romantismo, a poesia ancora-se sobre a teoria expressiva e rompe com a concepção mimética neoclássica. A perspectiva do olhar subjetivo ganha realce; o gênero lírico assume uma dignidade inédita: antes considerado um gênero médio na hierarquia poética antiga, alcança no romantismo as alturas do estilo sublime. O poeta romântico constata a impossibilidade de apreensão direta do objeto contemplado, mediado pela perspectiva particular do sujeito que o contempla sob a "luz dos sentimentos", impressões e sensações relativas. O artista não pode representar as coisas como são, mas somente como elas se parecem, aumentadas, distorcidas ou iluminadas pela "lente" de sua imaginação. A poesia se ocupa das emoções e processos da mente diante do objeto, e não do objeto em si. Situada no espaço interior, na mente do artista, a grande aventura não é mais representada na narração épica, com seus personagens envolvidos em grandes combates; o artista se torna o herói reflexivo de sua aventura criativa. Suas meditações, sensações e opiniões, e não a ação objetiva de personagens, movimentam o texto literário. ${ }^{541}$

romantismo não é "exaltação da produtividade incontrolada, da efusão sentimental desenfreada, da afirmação imediata da pura subjetividade do artista". A livre produtividade da arte "não é um procedimento inconsciente, privado de qualquer mediação intelectual" (p. 98). Segundo Schlegel, um poema ideal conjuga "intenção" e "instinto". Cf. SCHLEGEL, Friedrich, 1997, p.23.

537 D’ANGELO, Paolo, 1998, p.168.

${ }^{538}$ Idem, idem, p. 167.

539 LOMBARDO, Giovanni. "Longino", in: A Estética da Antiguidade Clássica. Lisboa: Editora Estampa, 2002, p. 190-191.

${ }^{540}$ Idem, idem, p. 182.

${ }^{541}$ Idem, idem, p.148. Abrams recorre a Henry Crabb Robinson para lembrar que a épica, por oposição, é produto de um poeta desinteressado em sua própria personalidade, que simula indiferença desapaixonada. A lírica, por sua vez, com suas odes, elegias e canções, destaca a mediação pela subjetividade a que os 
Na estética romântica, abundam analogias entre a arte e os estados da mente do poeta, notadas no repertório de metáforas ligadas à ideia de transbordamento: a poesia é concebida como produto gerado por um movimento que parte da interioridade e enfim se exterioriza. O gênero lírico se torna o mais adequado para a mimetização dos estados da alma, além de independer de personagens ou de argumento definido para se desenvolver. ${ }^{542}$ Por isso, o auditório deixa de ser o centro em torno do qual gravita a obra de arte: as ações da mente do poeta constituem-se o assunto principal do poema a partir de então. ${ }^{543}$ Nesta perspectiva, a poesia não deriva do objeto a ser imitado, mas do ânimo do contemplador diante desse objeto. A sensibilidade do artista deixa de ser receptora para se tornar produtora de realidade. M. H. Abrams emprega a metáfora do espelho e da lâmpada para exemplificar as teorias miméticas e expressivas, respectivamente. A primeira reflete a realidade circundante; a segunda incide a sua luz sobre o mundo, ampliando ou mesmo deformando-o. ${ }^{544}$

Esse processo de subjetivação das formas tradicionais é identificado por Antonio Candido no famoso poema "Meu sonho", de Álvares de Azevedo. Nele, o poeta assimila a estrutura da balada macabra, baseada em peripécias e personagens, para transpô-la na representação de um conflito interior. O poeta transforma um gênero narrativo corrente na Idade Media em outro essencialmente intimista. ${ }^{545} \mathrm{Em}$ análise ao poema "Ideias Íntimas”, Alcides Villaça, por sua vez, comenta o processo de criação de "pequenos mundos sonhados pela imaginação do poeta" Álvares de Azevedo. O olhar contemplativo do eu gera microcosmos artificiais, transformando os objetos concretos, espalhados pelo quarto descrito no poema, em abstrações: a realidade poética aqui é filtrada por uma cadeia de metáforas. Tudo se torna vago e indeterminado como a fumaça do charuto, que emoldura e estimula os livres devaneios do eu lírico. ${ }^{546}$

Nos capítulos anteriores desta dissertação, o movimento oscilante da fumaça do charuto foi constantemente aludido em $O$ poema do frade, sempre associado à disposição do narrador ao devaneio e às digressões. Como Jean Starobinski ressalta, a presença do devaneio como motor estruturante do discurso revela a tendência à representação de uma "audiência interna". O artista está ciente de que há uma

objetos são submetidos . Cf. ABRAMS, M. H. El espejo y la làmpara. Tradición critica acerca del hecho literário, trad. Gregorio Araóz. Buenos Aires: Editorial Nova, 1962 , p.352.

542 ABRAMS, idem, pp. 128-129.

543 "La fuente primera y el asunto de um poema, por consiguiente, son los atributos y las acciones de la mente del próprio poeta", in: Idem, p.39.

${ }^{544}$ Idem, p.81.

${ }^{545}$ CANDIDO, Antonio. O romantismo no Brasil. São Paulo: Humanitas, FFLCH, 2004, p. 90.

${ }^{546}$ VILLAÇA, Alcides. Na intimidade romântica, 1994, pp.19-20. 
defasagem jamais completamente superada entre o fato vivido e seu eco meditativo, portanto a obra de arte é concebida como "projeto imperfeitamente realizado" 547 , que pressupõe, necessariamente, o esforço infinito da reflexão, capaz de movimentar-se segundo o "perpétuo recomeço do devaneio". 548

\section{Sons e silêncio}

Conforme foi exposto mais acima, o poeta romântico busca superar a distância entre a Ideia e a forma-de-exposição na obra de arte. Diante do tema da insuficiência da palavra, é necessário lembrar que a música passa a ser encarada como arte sublime por excelência entre os românticos, por ser entendida como uma linguagem capaz de persuadir sem recorrer a conceitos. ${ }^{549}$ A poesia toma a música como modelo para si, e explora as sugestões sonoras das palavras, dispondo-as numa sintaxe poética especial, que seja capaz de recriar a mesma atmosfera mágica da linguagem musical, só alcançada por meio de um efeito de conjunto inalterável.

O próprio Álvares de Azevedo dedica-se a comentar a importância do modelo da linguagem musical para a poesia romântica, como via privilegiada de formulação de impressões, capazes de captar sentidos mais obscuros, fugazes ou de difícil conceituação percebidos na realidade. Na tentativa de recriar esse efeito sugestivo, o poeta recorre ao intenso emprego de cadeias metafóricas, que geram a sensação de prolixidade. No ensaio sobre "Alfredo de Musset", por exemplo, Azevedo fala da combinação da escrita com a música e com a pintura, com a finalidade de " traduzir o incerto do sentimento ou o vago das formas o flutuar vaporoso das expressões!" ${ }^{, 50}$, bem como reprova os críticos sem "música na alma":

Pobre gente! "não tem música na alma”, como Byron o disse - não compreendem essa intimidade da música com a pintura, de que fala Mme de Stäel - e acham absurdo para traduzir o incerto do sentimento, ou o vago das formas buscar o flutuar vaporoso das expressões! É lástima - que até Gustavo Planche satirize as Orientais do poeta das Folhas de outono, pelo seu título mais belo - o culto dos sons. ${ }^{551}$

547 STSROBINSKI, Jean, 1991, p. 373.

${ }^{548}$ Idem, idem, p.374.

${ }^{549}$ LOMBARDO, Giovanni. “Longino”, 2002, p. 194.

${ }^{550}$ AZEVEDO, Álvares de, “Alfred de Musset: Jacques Rolla”, 2000, p. 685.

551 Idem, idem, idem. 
Mais acima, no presente capítulo desta dissertação, comentou-se a intensa presença de vocabulário relacionado ao universo musical em $O$ poema do frade, como é são os casos de palavras como "sons", "lira", "voz", "música", "melodias", "canção", "nênia", entre outros, encontrados em profusão por volta das duas dezenas finais de sextilhas. Há outras referências além destas já citadas anteriormente, como "cordas de alaúde enternecido", "cordas de harmonia cheias", "infantil canção", "canto dos lânguidos amores", "moles sons de minha lira". Em uma passagem, o eu poético lamenta que a "virgem das canções" lhe tenha oferecido o "vinho da harmonia" precocemente, despertando-lhe o desejo (designado pela expressão "sons tão ofegantes") e tenha-lhe gerado a perda de sua inocência, sugerida pela "harpa adormecida" em seu peito:

\section{LVI}

E tão cedo! porque encher meu.leito Destas sombras suaves, delirantes? E na harpa adormecida de meu peito Suspirarem-me sons tão ofegantes?

E porque não deixar o meu sentir Da infância d'ouro nos frouxéis dormir?

As imagens musicais nos trechos finais do poema combinam-se às ideias de sede, insatisfação e movimento. Na tentativa de definir o sentido do "adeus" à existência e ao poema, o narrador combina-as também, em especial, à imagem da imensidão oceânica. Em uma passagem, o enunciador se vale de expressões como "beber sons" e escutar "harmonias" oceânicas. Suas memórias sucedem-se de maneira descontínua e fugaz, como a "vaga mansa/ De uma saudade que suspira e foge!" conforme já mencionado mais acima, a vastidão marítima inspira-lhe a contemplação "Em que se abisma o pensamento insano". 553

As especulações presentes nas sextilhas finais de $O$ poema do frade tornam o trecho prolixo e adiam o desfecho do poema, continuamente retardado, como se sugerisse que a profusão de metáforas presentes nos devaneios e meditações não pudesse dar conta de abarcar os mistérios escondidos por trás da morte. Os sentimentos de dor e mágoa profunda transformam-se em mudez e silêncio: os extremos da paixão

\footnotetext{
${ }^{552}$ Idem, "O poema do frade, 2002, Cf. estrofe XXVII do Canto Terceiro, p. 330.

${ }^{553}$ Idem, estrofe XLII, Canto Quinto, p. 359. A relação do eu romântico e contemplativo com a vastidão oceânica pode ser pensada na sublime desproporção do mar e sobretudo do céu, em comparação com a figura diminuta do sujeito que contempla essa paisagem no quadro Monge à beira-mar (1809), do célebre pintor romântico alemão Caspar David Friedrich.
} 
não cabem nos "versos eloquentes" e "bem rimados". Observa-se a tentativa do frade de evitar a profanação de ilusões, protegidas pela aura de mistério: "Eu não as profanei! guardo-as sentidas/ Nas longas noites do cismar aéreo,/ Guardo-as na esperança, nas doridas/ Horas que amor perfuma de mistério!" ${ }^{554}$, pois converter o sonho em concretude - em palavras - significa a sua inevitável ruína: o violento transbordar do peito do poeta estilhaça a corda de sua lira; o pensamento do "pobre sonhador" deseja fantasias intraduzíveis, inexprimíveis. Quase no final do Canto Quinto, o narrador compara a sua vida a um "alaúde aéreo", entregue a todos os alentos, que, tal como o libertino Don Juan, ressoa aos variados estímulos à sua volta. O discurso devaneante, "leviano" e "inconstante", tende à dispersão ${ }^{555}$ :

\section{XLVII}

Como o triste alcion vagueia errante

Nas frias primaveras do oceano

E ama as alvas, a noite sussurrante, Tardes, ondas e sol leviano

Na leviana afeição embriaga insano

A existência nos seios o inconstante:

\section{XLVIII}

Eu todos vos amei! cri no mistério Que o libertino Don Juan levava, Nas noites profanadas do adultério, Quando a alma sedenta evaporava! E a vida como um alaúde aéreo A todos os alentos entregava! $!^{556}$

O esforço do narrador em abarcar a realidade fragmentada leva-o à dispersão e à prolixidade, sem jamais conseguir plasmar forma e conteúdo de maneira definitiva. Duas estrofes adiante, além dessa última citada, finda o poema; no entanto, o desejo do narrador de "inda" volver à vida, "Se o fado" levar-lhe em "mágoa lenta", continua a

${ }^{554}$ Idem, estrofe XXIX, Canto Quinto, p. 356.

${ }^{555}$ A imagem do instrumento de corda sensível ao mais suave bafejo evoca a metáfora da harpa eólica, comentada por M. H. Abrams. Por meio dela, sugere-se a poesia como produto da tensão entre a interioridade do poeta (a harpa) e a realidade circundante (a oscilação do vento) ABRAMS, M. H, 1962, p.80. Abrams cita um trecho de "Defesa da poesia", no qual o poeta Shelley compara o homem a um instrumento que ressoa estimulado por impressões externas, produzindo melodias sempre variáveis. "El hombre [dice Shelley] es un instrumento sobre el cual una serie de impresiones externas son conducidas, como las alternâncias de um viento simpre cambiante sobre una lira eólia, que la impulsan com su movimiento a una melodia siempre cambiante. Pero hay un principio dentro del ser humano, y quizá dentro de todos los seres sensibles, que obra de otro modo que en la lira y produce no solo la melodia, sino la armonía, por un ajuste interno de los sonidos o los movimientos así excitados a las impresiones que los excitan".

A eleição da linguagem musical como modelo para a poesia leva à valorização do gênero lírico. Abrams cita a imagem de Ofélia, de Shakespeare, como um exemplo caro aos românticos, que enxergavam uma relação entre canto, loucura e paixão. A música, com sua linguagem misteriosa, explora as profundezas da alma, inacessíveis à razão e à linguagem verbal, ancorada sobre conceitos.

${ }^{556}$ AZEVEDO, Álvares de, "O poema do frade", 2002, p. 360. 
engendrar o seu movimento reflexivo característico: diferente de Jônatas e Consuelo, a possibilidade de sua morte é deixada em aberto, não chegando-se também a uma conclusão sobre as suas especulações metafísicas. Somente a vontade de movimento reflexivo infinito apresenta-se constante: "E quando a luz apague-se nos céus/ E o frio coração à dor sucumba/ Inda murmurarei — adeus! — da tumba!". ${ }^{557}$ Diante disso, pode-se dizer que, paradoxalmente, $O$ poema do frade é encerrado, mas não acaba propriamente.

Charles Rosen aponta na estética romântica uma essencial "recusa de alcançar o definitivo". 558 Ao valer-se da forma do fragmento, o romantismo valoriza a forma aberta, a dissonância e a contradição, desafiando o senso de resolução do leitor. $\mathrm{O}$ gênero permite a elaboração de obras de arte ao mesmo tempo completas mas inconclusas, maleáveis à infinita possibilidade de retorno e avanço da livre reflexão poética. ${ }^{559}$ Rosen discute as relações entre a escrita fragmentária e a linguagem musical, esta última entendida pelos românticos como a arte mais autônoma, capaz de manipular com liberdade as suas "formas e símbolos, aparentemente sem referência à própria realidade exterior". ${ }^{560}$ Os frágeis poderes de referência da música a tornam incapaz de definir o seu próprio conteúdo. No entanto, essa fraqueza imitativa foi vista pelos românticos como um grande trunfo, um território vasto e misterioso a ser explorado no reino das artes. A música "pura", instrumental, emancipa-se do canto e forma um sistema autônomo que questiona a finalidade comunicativa da obra de arte. Sua ambiguidade e imprecisão de movimentos são identificadas com as formas do arabesco, abstratas e destituídas de significado definido, que proporcionam a livre contemplação do ouvinte, gerando prazer intelectual. ${ }^{561}$ A adoção da linguagem musical como um modelo privilegiado para a poesia leva Novalis a sugerir a composição de

Contos, sem lógica, no entanto com associações, como sonhos. Poemas simplesmente sonoramente bons e preenchidos com lindas palavras —, mas também sem qualquer sentido ou lógica — no máximo simples estrofes

\footnotetext{
557 Idem, idem, estrofe L, p. 361.

${ }^{558}$ ROSEN, Charles. A geração romântica. Trad. Eduardo Seincman. Ed. ver. e ampl. São Paulo: Editora da Universidade de São Paulo, 2000 p.149.

559 Em outra passagem de seu livro, Rosen emprega a expressão: "conclusão ao mesmo tempo completa e incompleta" da obra de arte realizada, in: idem, p.859.

${ }^{560}$ Idem, idem, p.125. Ou, em outras palavras, a linguagem musical é a "arte que obtém os maiores efeitos sem que, aparentemente, tenha de se referir a algo que não seja ela própria”, p.198.

${ }^{561}$ Idem, idem, p.117. Tendo essas questões em vista, Rosen recorda o seguinte fragmento de Friedrich Schlegel: "Mas a música instrumental pura não cria, ela mesma, seu próprio texto? E não é seu tema desenvolvido, confirmado, variado, e contrastado, da mesma maneira que o objeto de meditação em uma série filosófica de ideias?”, cf. p. 120.
} 
inteligíveis - , devem ser como meras peças quebradas dos mais variados tipos. Na melhor das hipóteses, a verdadeira poesia tem de ter um sentido alegórico de conjunto, e um efeito indireto como a música etc. ${ }^{562}$

Rosen destaca que a composição musical romântica persegue o eco de uma melodia não tocada, inaudível, mas pressentida abstratamente pelo ouvido interno. Sua presença se afirma como ausência, lacuna permanente a remeter para algo além de si mesma. Neste sentido, o fragmento é um gênero marcado pela duplicidade: a forma acabada alude a um conteúdo incompleto e inesgotável. O artista romântico coloca para si a meta impraticável de perseguir esse sentido infinito. A obra de arte fragmentária tem um encerramento formal, no entanto se desenvolve de maneira progressiva e ecoa posteriormente à sua leitura. A obra inacabada e inacabável "já mostra, implicitamente, o ato da interpretação em movimento". ${ }^{563}$ Ao se valer do fragmento, o artista deixa sugerido no interior da própria escrita

os princípios de sua própria destruição. Muitas das formas literárias desse período são provisórias — não somente porque sejam experimentais, mas por ser impossível reproduzi-las. (...) Essas obras parecem estar eternamente proclamando a dificuldade de se manterem artisticamente íntegras, e sugerem ao leitor, os modos através dos quais podem ser erodidas. ${ }^{564}$

As obras de arte sentimentais nascem como ruína: "Muitas das obras dos antigos se tornaram fragmentos. Muitas obras dos modernos já o são ao surgir" ${ }^{565}$ Charles Rosen ressalta que o cultivo do fragmento não implica a destruição total da relação da parte com o todo, mas antes gera uma perturbação ao se inserir "um detalhe não resolvido que abala a simetria e as convenções da forma, sem que jamais realmente as destrua". 566

O emprego de imagens musicais para se conceber uma escrita pautada pelo fragmentário pode ser pensado, por exemplo, no prefácio à Primeira Parte de Lira dos

\footnotetext{
${ }^{562}$ Novalis, apud Rosen, in: 2000, pp. 124-125. Charles Rosen lembra que o modelo da linguagem da música instrumental teve consequências em campos como a pintura, na qual "as grandes representações da paisagem do romantismo não necessitavam mais de uma referência histórica, uma intriga ou um enredo", (p.335). Nela, também se verifica uma ruptura com a hierarquia dos gêneros tradicionais, na medida em que a pintura da paisagem passa a ser considerada mais sublime do que os gêneros histórico e religioso. Na paisagem romântica, projeta-se o humor e a sensibilidade do contemplador, a partir de seu olhar subjetivo. Cenas de contornos esmorecidos, como os crepúsculos, tornam-se temas recorrentes.

${ }^{563}$ ROSEN, Charles, 2000, p.92.

564 Idem, idem, p. 148.

${ }^{565}$ SCHLEGEL, Friedrich. O dialeto dos fragmentos, 1997, p.51.

566 ROSEN, Charles, 2000, p.151.
} 
vinte anos. Nele, Azevedo define seu livro como "uma lira, mas sem cordas". A ideia de ausência de cordas nessa lira imaginária é retomada mais adiante:

Cantos espontâneos do coração, vibrações doridas da lira interna que agitara um sonho, notas que o vento levou, — com isso dou a lume essas harmonias. São as páginas despedaçadas de um livro não lido... ${ }^{567}$

A lira é "interna", subjetivada, e designa uma poesia que não chegou a se realizar plenamente. $\mathrm{O}$ fragmento recusa a instauração de um sentido único, e recorda constantemente o leitor da necessidade de um continuum: da incessante necessidade de recomeçar o movimento engendrado pela crítica. Na escrita fragmentária, a lacuna, a ausência e o silêncio também são produtores de significado: "Os extremos se justapõem com pouco ou nenhum comentário mediador, e a Ideia surge no silêncio entre eles".568

Giovanni Lombardo comenta a profunda relação entre o silêncio e o estilo sublime. Segundo o estudioso, ela pode ser compreendida em um episódio da Odisseia, de Homero, no qual Ulisses desce aos infernos e reencontra Ájax, levado à morte pelo primeiro. Enquanto o herói de Ítaca argumenta, Ájax não reage; no entanto, a sua mudez revela uma paradoxal eloquência, sugerindo a dimensão imensa de sua indignação. Sua recusa em dirigir a palavra a Ulisses revela a "absoluta magnanimidade de um silêncio altivo e magnânimo". Nenhuma palavra seria capaz de abarcar o sentimento de Ájax, que permanece em sublime silêncio. Seu "pensamento destituído de voz" manifesta-se diretamente, sem a necessidade de articulação em um discurso. A simplicidade de seu silêncio revela um "pensamento nu, sem forma concreta, íntima", plasmada em uma expressão pré-textual: "a grandeza de Ajax recolhe-se toda nos pensamentos não expressos mas muito transparentes do herói: nenhum logos prophorikos, nenhum discurso confiado a uma voz perceptível poderia mais energicamente traduzir a sua indignação." 569

Lombardo ainda salienta que, para Longino, o estilo sublime serve de contraponto aos períodos de crise da democracia e dos costumes, nos quais a decadência moral acaba por contaminar todas as outras manifestações sociais, a ponto de gerar, inclusive, a "penúria das letras". É o embate entre a elevação e o rebaixamento. Quando todos os valores são rebaixados e "quando a liberdade política for desprezada, a

${ }^{567}$ AZEVEDO, Álvares de. "Lira dos vinte anos". In: Poesias completas, 2002, p.49.

${ }^{568}$ ROSEN, Charles. Poetas românticos, críticos e outros loucos. Tradução José Laurênio de Melo. São Paulo: Ateliê Editorial; Campinas: Editora Unicamp, 2004, p. 190.

${ }^{569}$ LOMBARDO, Giovanni. "Longino", in: A Estética da Antiguidade Clássica, 2002, p. 185. 
grandeza moral pode transparecer através de uma atitude orgulhosa e digna e, se necessário, até de um silêncio que sabe revelar-se mais eloquente do que um discurso". 570

Álvares de Azevedo representa o seu tempo como uma longa noite tormentosa - similar ao "eclipse" de que fala Longino —, onde ressoa, ao longe, a nênia do escravo e a pátria é violentada pelo capital estrangeiro. Ele nega-se a engrossar o coro ufanista do indianismo, voltando os seus olhos para o devir de uma nova literatura universal, para além da realidade estilhaçada pela alienação, pela violência e pela exploração mercantil. Quando todos os valores são rebaixados às trocas mercadológicas, a poesia, mesmo a venal, encontra a morte e a destruição, tal como Consuelo, alegoria dessa beleza atormentada e insustentável. Frustrada a possibilidade da epopeia moderna, a voz solitária do narrador de $O$ poema do frade ecoa no vazio e no silêncio, privado da presença de suas personagens. Perante o abismo do "não ser", o seu desejo é transcender o horizonte de morte e "inda" murmurar o seu "adeus! - da tumba!", em uma cadeia de ressonâncias intermináveis. Depois do "último clarão do arrebol”, na impossibilidade de "adiantar o dia", resta aos poetas fazer pelo menos "um serão de luar". 571

\footnotetext{
${ }^{570}$ Idem, idem, p. 196.

${ }^{571}$ AZEVEDO, Álvares de. "Literatura e civilização em Portugal”. In: Obra completa, 2000, p. 744.
} 


\section{Referências bibliográficas}

\section{a. De Álvares de Azevedo}

AZEVEDO, Álvares de. "O livro de Fra Gondicário", in: Obra completa, BUENO, Alexei (org.) Rio de Janeiro: Nova Aguilar, 2000, pp. 609-653.

. "Estudos literários", in: Obra completa, BUENO, Alexei (org.) Rio de Janeiro: Nova Aguilar, 2000, pp. 655-747.

. "Alfred de Musset: Jacques Rolla". In: Obra completa, BUENO, Alexei (org.) Rio de Janeiro: Nova Aguilar, 2000, pp. 678-705.

. "Literatura e civilização em Portugal". In: Obra completa, BUENO, Alexei (org.) Rio de Janeiro: Nova Aguilar, 2000, pp. 706-744.

. "Prefácio". Primeira Parte de Lira dos vinte anos, in: Poesias completas; edição crítica de Péricles Eugênio da Silva Ramos; Iumna Maria Simon (org), Campinas, SP: editora da Unicamp, São Paulo: Imprensa Oficial do Estado, 2002, p.49.

. "Prefácio". Segunda Parte de Lira dos vinte anos, in: Poesias completas; edição crítica de Péricles Eugênio da Silva Ramos; Iumna Maria Simon (org), Campinas, SP: editora da Unicamp, São Paulo: Imprensa Oficial do Estado, 2002, pp. 139-140.

. "O poema do frade", in: Poesias completas; edição crítica de Péricles Eugênio da Silva Ramos; Iumna Maria Simon (org), Campinas, SP: editora da Unicamp, São Paulo: Imprensa Oficial do Estado, 2002, pp. 303-361.

. "Prefácio" de $O$ conde Lopo. In: Poesias completas; edição crítica de Péricles Eugênio da Silva Ramos; Iumna Maria Simon (org), Campinas, SP: editora da Unicamp, São Paulo: Imprensa Oficial do Estado, 2002, pp. 369-376.

. "Lábios e sangue". Extrato de O livro de Fra Gondicário. In: Poesias completas; edição crítica de Péricles Eugênio da Silva Ramos; Iumna Maria Simon (org), Campinas, SP: editora da Unicamp, São Paulo: Imprensa Oficial do Estado, 2002, pp. 520-528.

."Macário". In: Macário; Noite na taverna. Organização, notas e prefácios de Cilaine Alves Cunha. São Paulo: Editora Globo, 2007, pp.15-97.

."Noite na taverna". In: Macário; Noite na taverna. Organização, notas e prefácios de Cilaine Alves Cunha. São Paulo: Editora Globo, 2007, pp.99-170.

\section{b. Bibliografia geral}

ABRAMS, M. H. El espejo y la làmpara. Tradición critica acerca del hecho literário, trad. Gregorio Araóz. Buenos Aires: Editorial Nova, 1962. 
ALENCAR, José de Alencar. "Cartas sobre a Confederação dos Tamoios". In: Caminhos do pensamento crítico. Organização de Afrânio Coutinho. Rio de Janeiro: Pallas/ Instituto Nacional do Livro/ Ministério da Educação e da Cultura, 1980, vol. I, pp. 80-104.

Prefácio de Iracema. In: Caminhos do pensamento crítico. Organização de Afrânio Coutinho. Rio de Janeiro: Pallas/ Instituto Nacional do Livro/ Ministério da Educação e da Cultura, 1980, vol. I, pp.114-115.

. "Carta sobre Iracema, ao Dr. Jaguaribe". In: Caminhos do pensamento crítico. Organização de Afrânio Coutinho. Rio de Janeiro: Pallas/ Instituto Nacional do Livro/ Ministério da Educação e da Cultura, 1980, vol. I, pp. 115-119.

ALVARENGA, Manuel Inácio da Silva. O desertor: poema herói-cômico; edição preparada por Ronald Polito; notas ao poema, Joaci Pereira Furtado e Ronald Polito. Campinas: Editora Unicamp, 2003.

ALVES, Cilaine. O belo e o disforme: Álvares de Azevedo e a ironia romântica. São Paulo: EDUSP/FAPESP, 1998.

. Entusiasmo indianista e ironia byroniana, São Paulo, 2000, Tese (Doutorado).

. "Peregrinações da ironia romântica de Machado de Assis". In: Ângulo 113, abr./jun., 2008, p. 35-43.

. "Tristeza de uma geração que termina", in: Teresa - Revista de Literatura Brasileira, n. 6/7. São Paulo: Humanitas, 2006.

ALVES, Maria Cláudia Rodrigues. O poeta leitor: um estudo das epígrafes hugoanas na obra de Álvares de Azevedo. São Paulo, 1999.

ARISTÓTELES. "Arte poética”. In: Arte retórica e arte poética. Clássicos Garnier. Difusão Européia do Livro, 1964.

ASSIS, de Machado. “Álvares de Azevedo”. In: Obra completa, BUENO, Alexei (org.) Rio de Janeiro: Nova Aguilar, 2000, pp. 24-26.

AZENHA JR, João. Robert Schumann (1810-1856) e os Escritos sobre a música e os músicos: a música como tradução da literatura. Tese de livre-docência. Faculdade de Filosofia, Letras e Ciências Humanas da USP. São Paulo, 2009.

BEGHAHN, Cord-Friedrich. "Poéticas de la contingencia: Los Efluvios cordiales de um monje amante del arte en el contexto del romanticismo temprano", in: WACKENRODER, Wilhelm Heinrich e TIECK, Ludwig. Efluvios cordiales de un monje amante del arte. Valencia: KRK Ediciones, 2008, pp. 265-298.

BENJAMIN, Walter. O conceito de crítica de arte no romantismo alemão. São Paulo. Editora Iluminuras, 1999.

. "Experiência e pobreza", in: Magia e técnica, arte e política: ensaios sobre literatura e história da cultura. 7. ed. São Paulo: Brasiliense, 1994 Obras Escolhidas, vol I, pp. 114-119.

. "O narrador: Considerações sobre a obra de Nikolai Leskov", in: Magia e técnica, arte e política: ensaios sobre literatura e história da cultura. 7. ed. São Paulo: Brasiliense, 1994 - Obras Escolhidas, vol I, pp. 197-221. 
. Origem do drama barroco alemão. Tradução de Sérgio Paulo Rouanet. São Paulo: Brasiliense, 1984.

BERMAN, Marshall. Tudo que é sólido desmancha no ar: a aventura da modernidade. São Paulo: Companhia das Letras, 1995.

BOLLE, Willi. "Friedrich Schlegel e a estética do fragmento". In: Fundadores da modernidade na literatura alemã. Eloá Heise (org.). São Paulo: FFLCH-USP, 1994, pp.35-45.

BORNHEIM, Gerd. "Filosofia do romantismo". In: $O$ Romantismo. GUINSBURG, Jacó (org). São Paulo: Ed. Perspectiva, 2008, 2ª reimpr. da 4. ed., pp. 75-112.

"Filosofia e literatura: espaço da estética". In: Páginas de Filosofia da Arte. Rio de Janeiro: UAPÊ, 1998, pp. 60-73.

"Uma temática hegeliana: a morte da arte". In: Páginas de Filosofia da Arte. Rio de Janeiro: UAPÊ, 1998, pp. 13-27.

BOSI, Alfredo. “Álvares de Azevedo”. In: História concisa da literatura brasileira. São Paulo: Editora Cultrix, pp. 121-124.

BOXER, Charles R. A Igreja Militante e a Expansão Ibérica: 1440-1770. São Paulo: Companhia das Letras, 2007.

BRANDÃO, Roberto de Oliveira. "Ultra jovem Álvares de Azevedo", In: Linha D’água. São Paulo, n.9, p.23-7, abr. 1995.

BRAYNER, Sônia. "O teatro do mundo na ilusão romanesca". In: O labirinto do espaço romancesco. Rio de Janeiro, MEC/Civilização Brasileira, 1979.

BROWN, Marshall. "Passion and Love: Anacreontic Song and The Roots of Romantic Lyric", in: English Literary History, Baltimore, v.66, n.2, p.373-404, Summer 1999, pp. 373-404.

BYRON. “Os amores de D. Juan”. In: Obras. Trad. de João Vieira, São Paulo: Edições Cultura, 1942, pp. 311-405. . D. Juan. New York: Modern Library, 1948.

CAMILO, Vagner. "Mito e História em Iracema". In: Novos estudos, 78, jul. 2007, pp. 169-189.

Risos entre pares: poesia e humor românticos. 1a. ed. São Paulo: Edusp/Fapesp, 1997.

. "Nos tempos de Antão: Considerações sobre as Sextilhas de Gonçalves Dias". Revista da USP, São Paulo, v. 40, 1998-1999, p. 105 - 113.

. "Álvares de Azevedo, o Fausto e o mito romântico do adolescente no contexto político-estudantil do Segundo Reinado". In: Itinerarios (UNESP. Araraquara), v. 33, 2011, p. 61-108.

CANDIDO, Antonio. "A educação pela noite". In: A educação pela noite e outros ensaios. São Paulo, Ática, 1989, pp. 10-22.

. (org) Introdução. In: Os melhores poemas de Álvares de Azevedo. São

Paulo, Global, 1994, pp. 9-19. 
. “Ariel ou Caliban". In: Álvares de Azevedo: Formação da literatura brasileira: momentos decisivos. Rio de Janeiro / Belo Horizonte: Itatiaia, 1993, v.2, pp. 159-172.

O romantismo no Brasil. São Paulo: Humanitas, FFLCH, 2004.

CAMPATO JR, José Adalberto. "A Confederação de Magalhães: Epopeia e necessidade cultural”, In: VÁRIOS. Épicos. Organização de Ivan Teixeira. São Paulo: Edusp/ Imprensa Oficial, 2008, pp. 829-845.

CANAL, Héctor. "Introducción", in: WACKENRODER, Wilhelm Heinrich e TIECK, Ludwig. Efluvios cordiales de un monje amante del arte. Valencia: KRK Ediciones, 2008, pp. 11-61.

CARNEIRO, Henrique Soares. "A fabricação do vício", in: LPH-Revista de História, Departamento de História/ICHS/UFOP: Mariana-MG, nº 12, 2002, p. 20, pp. 924.

CARVALHO, Ronald de. “Álvares de Azevedo (1831-1852) e a poesia da dúvida”, in: Obra completa, BUENO, Alexei (org.) Rio de Janeiro: Nova Aguilar, 2000, pp. 49-53.

CUNHA, Cilaine Alves. "O elogio da vagamundagem". In: SANTOS, Herbert Nunes de Almeida \& SILVA, Susana Souto. (Org.). Trilhas do humor na literatura brasileira. 1 ed. Maceió: EDUFAL, 2011, v. , p. 17-38.

CURTIUS, Ernst Robert. Literatura Europeia e Idade Média Latina. São Paulo: Hucitec/Edusp, 1996.

D’ANGELO, Paolo. A estética do romantismo. Tradução Isabel Teresa Santos. Lisboa: Estampa, 1998.

DAL FARRA, Maria Lúcia. "Complexo de Lopo". In: Scripta, Belo Horizonte, v.10, n. 19, p.122-130, 2o sem. 2006.

DIAFÉRIA, Celina. “Apresentação”. In: MOLIÈRE. Don Juan. Tradução de Celina Diaféria. São Paulo: Hedra, 2006.

DIAS, Gonçalves. "As sextilhas de Frei Antão". In: Poesia e prosa completas; organização Alexei Bueno. Rio de Janeiro: Editora Nova Aguilar, 1998, pp. 297-366.

DIDEROT, Denis. Jacques, o fatalista, e seu amo. Trad., apresentação e notas de Magnólia Costa Santos. São Paulo: Nova Alexandria, 2001.

DUARTE, Lelia Parreira. Ironia e humor na literatura. Belo Horizonte: Editora PUC Minas, São Paulo: Alameda, 2006.

ELÍSIO, Filinto. "A Variedade”, in: Obras completas de Filinto Elísio. Organização de Francisco Manuel do Nascimento. Braga: APPACDM Distrital de Braga, 1998, vol. 5, pp. 62-68.

FRANCHETTI, Paulo. "O triunfo do romantismo: Indianismo e estilização épica em Gonçalves Dias”, In: VÁRIOS. Épicos. Organização de Ivan Teixeira. São Paulo: Edusp/ Imprensa Oficial, 2008, pp. 1097-1125.

. “Álvares de Azevedo (1831-1852)". Publicado em Brasiliana USP: http://www.brasiliana.usp.br/node/433. Consultado em 20/05/2012. 
FRIEDRICH, Hugo. Estrutura da lírica moderna: da metade do século XIX a meados do século XX. São Paulo: Duas Cidades, 1978.

GAGLIARDI, Caio. "O problema da autoria literária: apagamentos, retomadas e revisões”, in: Estudos Avançados (USP. Impresso), v. 1, p. 285-299, 2010, pp. 285-299.

GINZBURG, Jaime. "O conceito de fragmentação em suas elaborações no Romantismo e em textos da teoria da literatura contemporânea" In: IV Congresso da Associação Brasileira de Literatura Comparada, 1995, São Paulo. Literatura e Diferença. IV Congresso ABRALIC. São Paulo: ABRALIC, 1995. p. 425-428.

. Olhos turvos, mente errante: elementos melancólicos em Lira dos vinte anos, de Álvares de Azevedo. Universidade Federal do Rio Grande do Sul, 1997.

GUINSBURG, J. (org.) O Romantismo. São Paulo: Perspectiva, 1993.

GOETHE, Johann Wolfgang von. Fausto: uma tragédia. São Paulo: Editora 34, 2004.

HANSEN, João Adolfo. "Forma romântica e psicologismo crítico". In: ALVES, CILAINE. O belo e o disforme: Álvares de Azevedo e a ironia romântica. São Paulo: EDUSP/FAPESP, 1998, pp. 09-23.

. "Notas sobre o gênero épico". In: VÁRIOS. Épicos. Organização de Ivan Teixeira. São Paulo: Edusp/ Imprensa Oficial, 2008, pp. 15-91.

HERCULANO, Alexandre. "Alexandre Herculano crítico da Confederação", in: RAEDERS, Georges. Dom Pedro II e os sábios franceses. Rio de Janeiro: Atlântica Editora, 1944, pp. 201-215.

. "Futuro Literário de Portugal e do Brasil", In: DIAS, Gonçalves. Poesia e prosa completas. BUENO, Alexei (org). Rio de Janeiro: Editora Nova Aguilar, 1998, pp. 97-100.

HOFFMANN, E. T. A. Los elixires del diablo. Trad. Emilio J. González García. Madrid: Ediciones Akal, 2008.

HOMERO. Odisseia. Tradução de Odorico Mendes. São Paulo: Edusp, 2000.

HORÁCIO. Arte poética. Trad. R. M. Rosado Fernandes. Lisboa: Editorial Inquérito, 1984.

HORTA, Anderson Braga. A aventura espiritual de Álvares de Azevedo: estudo e antologia. Brasília: Thesaurus EDITORA, 2002.

HUME, David. "Da tragédia". In: Hume: vida e obra. Col. Os Pensadores. São Paulo: Nova Cultural, 2000, pp. 325-331.

JAEGER, Werner. Paideia: A Formação do Homem Grego. $3^{\text {a }}$ edição. São Paulo: Martins Fontes, 1995.

KIERKEGAARD, Soren. O conceito de ironia constantemente referido a Sócrates. Apresentação e tradução Álvaro Luiz Montenegro Valls. Petrópolis, RJ : Vozes, 1991.

KOSSOVITCH, Elisa Angotti. "Don Juan e Sade: sedução e perversão na escritura”. In: A sedução e suas máscaras: ensaios sobre Don Juan. São Paulo: Companhia das Letras, 1988, pp. 77-82.

KOSSOVITCH, Leon. "O sentido da Renascença”. In: Jornal de resenhas. No. 5, 07/08/1995, pp. 148-150. 
LAMARTINE, Alphonse de. Jocelyn. Rio de Janeiro: Papelaria Central, 1911.

LESSING, Gotthold Ephraim. Laocoonte, ou sobre as fronteiras entre a pintura e a poesia. Introd., trad. e notas de Mário Selignann-Silva. São Paulo: Editora Iluminuras, 1998.

LYRA, Pedro. "Roteiro para uma leitura de Jerusalém Libertada", in: TASSO, Torquato. Jerusalém Libertada. Rio de Janeiro, Topbooks/ Centro Universitário da Cidade, 1998.

LOMBARDO, Giovanni. "Longino", in: A Estética da Antiguidade Clássica. Lisboa: Editora Estampa, 2002, pp. 179-196.

LUCCHESI, Marco, in: TASSO, Torquato. Jerusalém Libertada. Rio de Janeiro, Topbooks/ Centro Universitário da Cidade, 1998.

MAGALHÃES, Gonçalves de. "Discurso sobre a História da Literatura do Brasil", In: Caminhos do pensamento crítico. Organização de Afrânio Coutinho. Rio de Janeiro: Pallas/ Instituto Nacional do Livro/ Ministério da Educação e da Cultura, 1980, vol. I, pp. 23-38.

- "Lede". In: Caminhos do pensamento crítico, organização de Afrânio Coutinho. Rio de Janeiro: Pallas/ Instituto Nacional do Livro/ Ministério da Educação e da Cultura, 1980, vol. I, pp. 39-41.

. A Confederação dos Tamoios. In: Épicos. Organização de Ivan Teixeira. São Paulo: Edusp/Imprensa Oficial, 2008, pp. 847-1093.

MATTOS, Franklin de. A cadeia secreta: Diderot e o romance filosófico. São Paulo: Cosac \& Naif, 2004.

MERQUIOR, José Guilherme. "Álvares de Azevedo". In: AZEVEDO, Álvares de. Obra completa. BUENO, Alexei (org.) Rio de Janeiro: Nova Aguilar, 2000, p. 96-98.

MOISÉS, Massaud. Dicionário de termos literários. Cultrix, 2004.

MOLIÈRE. Don Juan. Tradução de Celina Diaféria. São Paulo: Hedra, 2006.

MONTEIRO, Jaci. “Álvares de Azevedo”, in: Obra completa, BUENO, Alexei (org.) Rio de Janeiro: Nova Aguilar, 2000, pp. 19-24.

MÜNSTER, Reinhold. "Con hermosa anarquía”, in: Lucinde. Valencia: Editorial Natán, 1987, pp. I-XXXIV.

MUSSET, Alfred de. A Confissão de um Filho do Século. São Paulo: Editora Escala, sem data.

NIETZSCHE, Friedrich. O nascimento da tragédia. Trad., notas e posfácio de J. Guinsburg. São Paulo: Companhia das Letras (col. Companhia de Bolso), 2007.

NORBERTO, Joaquim. "Álvares de Azevedo visto por alguns críticos e historiadores literários", in: AZEVEDO, Álvares de. Noite na taverna. Organização de Hildon Rocha. Rio de Janeiro: Livraria Francisco Alves, 1991, p.16.

NOVALIS. Pólen: fragmentos, diálogos, monólogo. Trad., apresentação e notas de Rubens Rodrigues Torres Filho. São Paulo: Iluminuras, 1998.

OLIVEIRA, Jefferson Donizeti de. Um sussurro nas trevas: uma recepção da recepção crítica e literária de Noite na Taverna, de Álvares de Azevedo. São Paulo: FFLCH-USP, 2010 (Dissertação de mestrado). 
OSBORNE, Harold. "A estética inglesa do século XVIII". In: Estética e teoria da arte: uma introdução histórica. Trad. de Octávio Mendes Cajado. São Paulo: Editora Cultrix, pp. 133-154.

"A crítica do Juízo de Kant". In: Estética e teoria da arte: uma introdução histórica. Trad. de Octávio Mendes Cajado. São Paulo: Editora Cultrix, pp. 155-177.

"A estética do romantismo". Estética e teoria da arte: uma introdução histórica. Trad. de Octávio Mendes Cajado. São Paulo: Editora Cultrix, pp. 178208.

PAES, José Paulo. "Sterne, ou o horror à linha reta", in: A vida e as opiniões do cavalheiro Tristram Shandy. Tradução, introdução e notas de José Paulo Paes. Rio de Janeiro: Nova Fronteira, 1984, pp.07-40.

PAZ, Octavio. Os filhos do barro: do romantismo à vanguarda. Trad. de Olga Savary. Rio de Janeiro: Nova Fronteira, 1984.

PERRONE-MOISÉS, Leyla. "O Vácuo-Pessoa”. In: Fernando Pessoa, aquém do eu, além do outro. São Paulo: Martins Fontes, 2001, pp. 71-112.

PIRES, Homero. "Introdução", in: AZEVEDO, Álvares de. Obras completas de Álvares de Azevedo, organização de Homero Pires. 8. ed. São Paulo: Nacional, 1942, vol. 1 vol. 1.

PRADO, Raquel de Almeida. Perversão da retórica, retórica da perversão: moralidade e forma literária em "As ligações perigosas" de Choderlos de Laclos. São Paulo: Editora 34, 1997.

PRAZ, Mario. A carne, a morte e o diabo na literatura romântica. Trad. de Philadelpho Menezes. Campinas: UNICAMP, 1996.

RAMOS, Péricles Eugênio da Silva. "Introdução". In: Poesias completas; edição crítica de Péricles Eugênio da Silva Ramos; Iumna Maria Simon (org), Campinas, SP: editora da Unicamp, São Paulo: Imprensa Oficial do Estado, 2002, pp.21-42.

RIBEIRO, Santiago Nunes. "Da nacionalidade da literatura brasileira", in: Caminhos do pensamento crítico. Organização de Afrânio Coutinho. Rio de Janeiro: Pallas/ Instituto Nacional do Livro/ Ministério da Educação e da Cultura, 1980, vol. I, pp. 43-73.

ROMERO, Silvio. "Álvares de Azevedo", in: Obra completa, BUENO, Alexei (org.) Rio de Janeiro: Nova Aguilar, 2000, pp. 26-43.

ROSEN, Charles. A geração romântica. Trad. Eduardo Seincman. Ed. ver. e ampl. São Paulo: Editora da Universidade de São Paulo, 2000.

. Poetas românticos, críticos e outros loucos. Tradução José Laurênio de Melo. São Paulo: Ateliê Editorial; Campinas: Editora Unicamp, 2004.

ROSENFELD, Anatol. “Aspectos do romantismo alemão". In: Texto Contexto. São Paulo: Editora Perspectiva, 1996, pp. 147-171.

ROUSSEAU, Jean-Jacques. Carta a D'Alembert. Trad. de Roberto Leal Pereira. Campinas: Editora UNICAMP, 1993.

. Devaneios de um caminhante solitário. Tradução de Fúlvia Maria Luiza Moretto. Brasília: UNB, 1986. 
SAFRANSKI, Rüdiger. Romantismo: uma questão alemã. Tradução de Rita Rios. São Paulo: Estação Liberdade, 2010.

SANTOS, Laymert Garcia dos. "Don Juan e o nome da sedução". In: A sedução e suas máscaras: ensaios sobre Don Juan. São Paulo: Companhia das Letras, 1988, pp. 23-37.

SANTOS, Wellington de Almeida. "Álvares de Azevedo e a ironia romântica", in: Obra completa, BUENO, Alexei (org.) Rio de Janeiro: Nova Aguilar, 2000, pp. 100109.

SCHLEGEL, August. "Reseña de Efluvios cordiales de un monje amante del arte", in: WACKENRODER, Wilhelm Heinrich e TIECK, Ludwig. Efluvios cordiales de un monje amante del arte. Valencia: KRK Ediciones, 2008, pp. 251-263.

SCHLEGEL, Friedrich. O dialeto dos fragmentos. Trad. Márcio Suzuki. São Paulo: Editora Iluminuras, 1997. . Sobre el estudio de la poesía griega. Madrid: Akal, 1996.

. Conversa sobre poesia e outros fragmentos, Tradução, prefácio e notas: Victor-Pierre Stirnimann, São Paulo, Iluminuras, 1994.

. Lucinde. Traducción y notas de Berta Raposo, Introducción de Reinhold Münster. Valencia: Editorial Natán, 1987.

SCHILlER, F. Poesia ingênua e sentimental. Trad. Márcio Suzuki. São Paulo: Iluminuras, 1991.

“Acerca do sublime”, in: Teoria da tragédia. Introd. e notas de Anatol Rosenfeld. São Paulo: EPU, 1991, pp. 49-70.

SCHMITT, Juliana. Mortes vitorianas: corpos, luto e vestuário. São Paulo: Alameda, 2010.

SHAKESPEARE, William. Hamlet; tradução de Millôr Fernandes. Porto Alegre: L\&PM, 2010.

Ricardo III. Tradução, prefácio e notas de Beatriz Viegas Faria. Porto Alegre: L\&PM, 2010.

SOUZA, Joaquim Norberto de, “Álvares de Azevedo visto por alguns críticos e historiadores literários" in: in: AZEVEDO, Álvares de. Noite na taverna. Organização de Hildon Rocha. Rio de Janeiro: Livraria Francisco Alves, 1991, p. 16.

STAROBINSKI, Jean. "O fuzil de dois tiros de Voltaire". In: As máscaras da civilização: ensaios. Trad. de Maria Lúcia Machado. São Paulo: Companhia das Letras, 2001, pp. 119-161.

. "Devaneio e transmutação". In: Rousseau: a transparência e o obstáculo. São Paulo: Companhia das Letras, 1991, pp. 361-374.

STERNE, Laurence. A vida e as opiniões do cavalheiro Tristram Shandy.Trad., introd., e notas de José Paulo Paes. Rio de Janeiro: Nova Fronteira, 1984.

SUASSUNA, Ariano. Iniciação à estética. 2. ed. Recife : Universidade Federal, 1979.

SUZUKI, Márcio. O gênio romântico: crítica e história da filosofia em Friedrich Schlegel. São Paulo: Iluminuras, 1998. 
. "Sobre música e ironia". Dois Pontos, Curitiba, São Carlos, v. 4, n. 1, abr., 2007, pp. 175-200.

TASSO, Torquato. Jerusalém Libertada. Tradução de José Ramos Coelho. Rio de Janeiro, Topbooks/ Centro Universitário da Cidade, 1998.

TEIXEIRA, Ivan. Mecenato Pombalino e Poesia Neoclássica. São Paulo: Editora da Universidade de São Paulo, 1999.

VÁRIOS. Épicos. Organização de Ivan Teixeira. São Paulo: Edusp/ Imprensa Oficial, 2008.

VERÍSSIMO, José. “Álvares de Azevedo”, in: Obra completa, BUENO, Alexei (org.) Rio de Janeiro: Nova Aguilar, 2000, pp. 43-46.

VERMES, Mónica. Crítica e criação: um estudo da Kreisleriana Op. 16 de Robert Schumann. Cotia : Ateliê, 2007 : FAPESP.

VIDEIRA JR, Mario Rodrigues. A linguagem do inefável: música e autonomia estética no Romantismo. Tese de doutorado. Faculdade de Filosofia, Letras e Ciências Humanas da USP, São Paulo, 2009.

VILELA, Ivan. "Na toada da viola", in: REVISTA USP, São Paulo, n.64, dezembro/fevereiro 2004-2005, pp. 76-85.

VILLAÇA, Alcides Celso de Oliveira. "Afinação e dissonância”, in: Folha de São Paulo. Jornal de Resenhas São Paulo, 9 fev. 2002. p. 3.

. "O riso de um soneto", in: Todas as Letras, Revista de Língua e Literatura. São Paulo, n. 1, 1999, pp. 27-33.

. "Na intimidade romântica". In: AZEVEDO, Álvares de. Lira dos Vinte Anos. São Paulo, 1994, pp. 9-21.

VITRÚVIO. Tratado de arquitetura. MACIEL, Justino (org.). Lisboa: Instituto Superior Técnico/IFT Press, 2006, pp. 29-41.

VOLOBUEF, Karin. Frestas e arestas: a prosa de ficção do romantismo na Alemanha e no Brasil. São Paulo: Fundação Editora da UNESP, 1998.

VOLTAIRE. "O ingênuo”. In: Romances e contos. Trad. Lívio Teixeira. Vol. 1. São Paulo: Difusão Européia do Livro, 1959, pp. 247-308.

WACKENRODER, Wilhelm Heinrich e TIECK, Ludwig. Efluvios cordiales de un monje amante del arte. Valencia: KRK Ediciones, 2008.

WERKEMA, Andréa Sirihal. Macário, ou o drama romântico em Álvares de Azevedo. Tese de doutorado, UFMG, 2007.

WERLE, Marco Aurélio. "O mar e a alma: metáforas marinhas em território alemão". Trans/Form/Ação, vol. 30, n. 1, São Paulo, 2007, pp. 225-234.

WINCKELMANN, J. J. Reflexões sobre a arte antiga. Estudo intr. de Gerd A. Bornheim. Trad. de Herbert Caro e Leonardo Tochtrop. Porto Alegre: Movimento/ Universidade Federal do Rio Grande do Sul, 1975.

WÖLFFLIN, Heinrich. Conceitos fundamentais da História da Arte. $6^{\text {a }}$ ed. São Paulo: Martins Fontes, 2006. 